\title{
Underwater Archaeology at 41HY147, the Terrace Locality at Spring Lake
}

Jon C. Lohse

Follow this and additional works at: https://scholarworks.sfasu.edu/ita

Part of the American Material Culture Commons, Archaeological Anthropology Commons, Environmental Studies Commons, Other American Studies Commons, Other Arts and Humanities Commons, Other History of Art, Architecture, and Archaeology Commons, and the United States History Commons

Tell us how this article helped you.

This Article is brought to you for free and open access by the Center for Regional Heritage Research at SFA ScholarWorks. It has been accepted for inclusion in Index of Texas Archaeology: Open Access Gray Literature from the Lone Star State by an authorized editor of SFA ScholarWorks. For more information, please contact cdsscholarworks@sfasu.edu. 
Underwater Archaeology at $41 \mathrm{HY} 147$, the Terrace Locality at Spring Lake

Creative Commons License

(c) $)(1)$ (9)

This work is licensed under a Creative Commons Attribution-NonCommercial 4.0 International License 


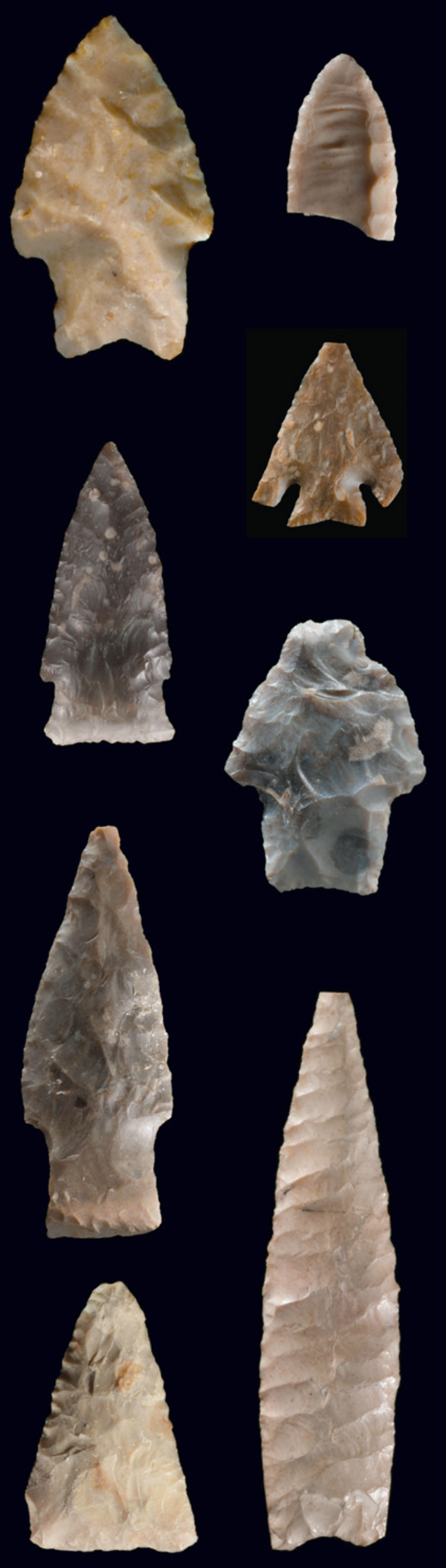

\section{UNDERWATER ARGHAEOLOGY AT 41N147,

Jon C. Lohse, editor

artifact photographs by Margie C. Elliott

drawings by Richard L. McReynolds

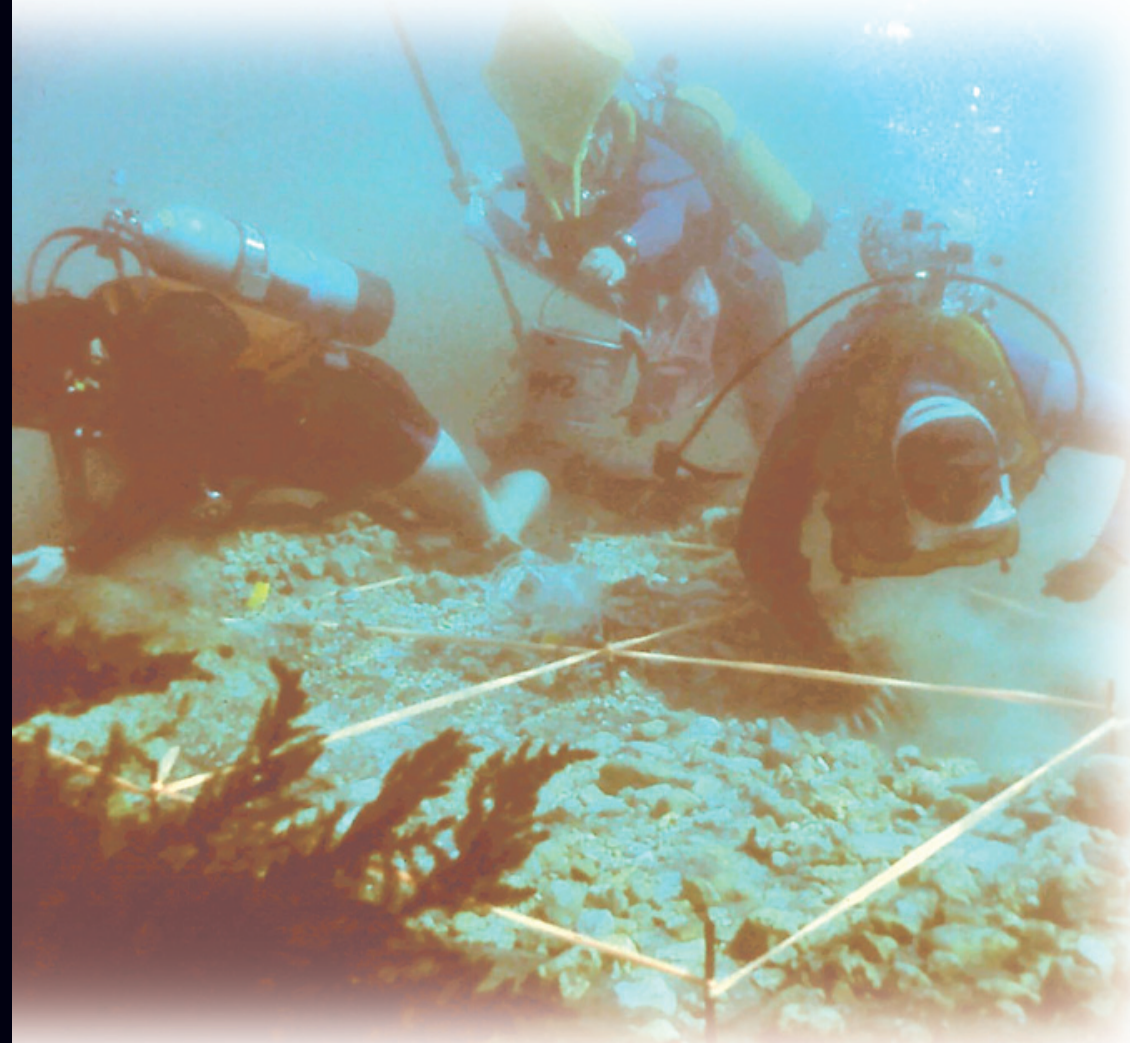

Archaeological Studies Report No. 28

Center for Archaeological Studies

Texas State University-San Marcos 
Underwater Archaeology at 41HY147, the Terrace Locality at Spring Lake 



\title{
Underwater Archaeology at 41HY147, the Terrace Locality at Spring Lake
}

\author{
Edited by Jon C. Lohse
}

Artifact photographs by Margie C. Elliott

Drawings by Richard L. McReynolds

Archaeological Studies Report No. 28

Center for Archaeological Studies

Texas State University-San Marcos 
The following information is provided in accordance with the General Rules of Practice and Procedures, Title 13, Chapter 26, Texas Administrative Code

1. Type of investigation: alternative mitigation

2. Project Name: Spring Lake Aquatic Ecosystem Restoration Project, Texas

3. County: Hays

4. Principal Investigator: Carole A. Leezer

5. Name and location of sponsoring agency: Texas State University-San Marcos, 601 University Drive, San Marcos, Texas

78666

6. Published by the Center for Archaeological Studies, Texas State University-San Marcos, 601 University Drive, San Marcos, Texas 78666-4616

Copyright (C) 2013 by

the Center for Archaeological Studies, Texas State University-San Marcos

All rights reserved

No part of this book may be reproduced or utilized in any form or by any means, electronic or mechanical, including photocopying, recording, or by any information storage and retrieval system without permission in writing.

For further information about this and other publications by the Center for Archaeological Studies, please contact

Center for Archaeological Studies

Texas State University-San Marcos

601 University Drive

San Marcos, Texas 78666-4616

www.txstate.edu/anthropoloy/cas

Texas State University-San Marcos is a member of the Texas State University System

Printed in the United States of America 


\section{Contents}

List of Figures and Table . . . . . . . . . . . . . . . . . . . . . . . . . xi

Abstract . . . . . . . . . . . . . . . . . . . . . . . . $\mathrm{xv}$

Chapter 1. Introduction. . . . . . . . . . . . . . . . . . . . . . . . . . 1

Chapter 2. Underwater Excavations at 41HY147 . . . . . . . . . . . . . . . 5

Shiner's Work . . . . . . . . . . . . . . . . . . . . . . . . . . 6

Making Sense of the Terrace Locality. . . . . . . . . . . . . . . . . . 10

Takac's Work. . . . . . . . . . . . . . . . . . . . . . . 13

Spring Lake Today . . . . . . . . . . . . . . . . . . . . . . . . . . 15

Chapter 3. Projectile Points and Other Lithics . . . . . . . . . . . . . . . . 17

Projectile Points . . . . . . . . . . . . . . . . . . . . . . . . . . . 18

Dart Points . . . . . . . . . . . . . . . . . . . . . . . . . . . . 18

Abasolo-like . . . . . . . . . . . . . . . . . . . . . . . . . . 18

Andice . . . . . . . . . . . . . . . . . . . . . . . . . . . . 18

Angostura . . . . . . . . . . . . . . . . . . . . . . . . . . . 19

Angostura Preform . . . . . . . . . . . . . . . . . . . . . . . . 20

Bandy . . . . . . . . . . . . . . . . . . . . . . . . . . . 20

Base- and Side-Notched . . . . . . . . . . . . . . . . . . . . .21

Bell . . . . . . . . . . . . . . . . . . . . . . . . . . 21

Big Sandy . . . . . . . . . . . . . . . . . . . . . . . . . . . 22

Bulverde . . . . . . . . . . . . . . . . . . . . . . 23

Castroville. . . . . . . . . . . . . . . . . . . . . . . . 23

Clovis. . . . . . . . . . . . . . . . . . . . . . . . . 24

Possible Clovis Base . . . . . . . . . . . . . . . . . . . . . . .25

Darl . . . . . . . . . . . . . . . . . . . . . . . 25

Early Barbed. . . . . . . . . . . . . . . . . . . . . . . . . . 26

Early Triangular . . . . . . . . . . . . . . . . . . . . . . . . 26

Ensor . . . . . . . . . . . . . . . . . . . . . . . . . . 27

Evant. . . . . . . . . . . . . . . . . . . . . . 28

Fairland . . . . . . . . . . . . . . . . . . . . . . . . . . . 29

Folsom . . . . . . . . . . . . . . . . . . . . . . . . . . 29

Possible Folsom Base . . . . . . . . . . . . . . . . . . . . . . 29

Frio . . . . . . . . . . . . . . . . . . . . . . 30

Golondrina . . . . . . . . . . . . . . . . . . . . . . . . . . 30

Hoxie . . . . . . . . . . . . . . . . . . . . . . . . . . . . . 31

Jetta . . . . . . . . . . . . . . . . . . . . . . .31

Laguna . . . . . . . . . . . . . . . . . . . . . . . . . . 32 
Lange. . . . . . . . . . . . . . . . . . . . . . . . 32

Langtry . . . . . . . . . . . . . . . . . . . . . . . . . . 33

Marcos . . . . . . . . . . . . . . . . . . . . . . 34

Marshall . . . . . . . . . . . . . . . . . . . . . . . . . . . . 34

Martindale . . . . . . . . . . . . . . . . . . . . . . 35

Merrell . . . . . . . . . . . . . . . . . . . . . . . 36

Montell . . . . . . . . . . . . . . . . . . . . . . . . . . . 36

Nolan . . . . . . . . . . . . . . . . . . . . . . . 36

Pedernales. . . . . . . . . . . . . . . . . . . . . . . . . . . . 37

San Patrice . . . . . . . . . . . . . . . . . . . . . . . . . . . 39

St. Mary's Hall . . . . . . . . . . . . . . . . . . . . . . . . . .440

Travis . . . . . . . . . . . . . . . . . . . . . 41

Uvalde/Gower . . . . . . . . . . . . . . . . . . . . . . . . . .4 42

Val Verde-like . . . . . . . . . . . . . . . . . . . . . . . . . . 43

Williams . . . . . . . . . . . . . . . . . . . . . 43

Wilson . . . . . . . . . . . . . . . . . . . . . . . . 43

Untyped and Unclassifiable Dart Points. . . . . . . . . . . . . . . . 45

Dart Point Fragments . . . . . . . . . . . . . . . . . . . . . . . 45

Arrow Points. . . . . . . . . . . . . . . . . . . . . . . . 45

Edwards . . . . . . . . . . . . . . . . . . . . . . . . . . . .4 45

Perdiz . . . . . . . . . . . . . . . . . . . . . 46

Scallorn. . . . . . . . . . . . . . . . . . . . . . . . 46

Arrow Point Fragments . . . . . . . . . . . . . . . . . . . . . . 47

Other Stone Tools and Artifacts . . . . . . . . . . . . . . . . . . . . . 47

Multipurpose Bifacial Tool . . . . . . . . . . . . . . . . . . . . . . 47

Large Drills . . . . . . . . . . . . . . . . . . . . . . . . . . . .47

Beveled Knife . . . . . . . . . . . . . . . . . . . . . . . . . . .48

Large End Scraper . . . . . . . . . . . . . . . . . . . . . . . . . 48

Small End Scraper . . . . . . . . . . . . . . . . . . . . . . . . .49

Clear Fork Adzes . . . . . . . . . . . . . . . . . . . . . . . . . . 49

Adzes Made on Point Fragments. . . . . . . . . . . . . . . . . . . 50

Miscellaneous Adzes. . . . . . . . . . . . . . . . . . . . . . . . 50

Lunate Uniface. . . . . . . . . . . . . . . . . . . . . . . . . . .50

Chapter 4. A Glance Through 13,500 Years. . . . . . . . . . . . . . . . . . 53

How Archaeologists Tell Time. . . . . . . . . . . . . . . . . . . . . .54

Absolute dates . . . . . . . . . . . . . . . . . . . . . . . . . . . 54

Relative ages. . . . . . . . . . . . . . . . . . . . . . . . 55

Cross-Dating. . . . . . . . . . . . . . . . . . . . . . . 55

13,500 Years at Spring Lake . . . . . . . . . . . . . . . . . . . . . .58 
Archaeological Time Divisions. . . . . . . . . . . . . . . . . . . . . .58

Paleoindian . . . . . . . . . . . . . . . . . . . . . . . . . 60

Archaic . . . . . . . . . . . . . . . . . . . . . . . . . . . 62

Early Archaic . . . . . . . . . . . . . . . . . . . . . . . . . . 64

Middle Archaic . . . . . . . . . . . . . . . . . . . . . . . . . . 70

Late Archaic . . . . . . . . . . . . . . . . . . . . . . . . . . . 72

Transitional Archaic/Austin . . . . . . . . . . . . . . . . . . . . . . . . . 76

Late Prehistoric . . . . . . . . . . . . . . . . . . . . . . . . . .78

The Rest of the Story . . . . . . . . . . . . . . . . . . . . . . . . 82

Appendix A. Projectile Points . . . . . . . . . . . . . . . . . . . . . . 85

Appendix B. Projectile Point Fragments . . . . . . . . . . . . . . . . . . 105

Appendix C. Untyped Biface Preforms . . . . . . . . . . . . . . . . . . . 115

Appendix D. Other Tools and Artifacts . . . . . . . . . . . . . . . . . . 119

References Cited . . . . . . . . . . . . . . . . . . 123 



\section{List of Figures and Table}

Figure 1-1. Panoramic photomosaic of Spring Lake . . . . . . . . . . . . . . . . 1

Figure 1-2. Regional map of Central Texas . . . . . . . . . . . . . . . . . . . 2

Figure 2-1. Joel Shiner at Spring Lake . . . . . . . . . . . . . . . . . . . . . 5

Figure 2-2. LIDAR and bathymetric map of Spring Lake . . . . . . . . . . . . . . 7

Figure 2-3. Joel Shiner and assistant screening sediments . . . . . . . . . . . . . 8

Figure 2-4. Divers excavating at the Terrace Locality . . . . . . . . . . . . . . . 9

Figure 2-5. Profile of northeast wall of Terrace Locality excavation . . . . . . . . . 11

Figure 2-6. Ground-penetrating radar at Spring Lake . . . . . . . . . . . . . . 14

Figure 3-1. Abasolo-like point . . . . . . . . . . . . . . . . . . . . . . . . 18

Figure 3-2. Andice points. . . . . . . . . . . . . . . . . . . . . . . . . . 19

Figure 3-3. Angostura points . . . . . . . . . . . . . . . . . . . . . . . . 20

Figure 3-4. Bandy points . . . . . . . . . . . . . . . . . . . . . . . . . . 21

Figure 3-5. Base- and side-notched point . . . . . . . . . . . . . . . . . . . 21

Figure 3-6. Big Sandy point. . . . . . . . . . . . . . . . . . . . . . . . . 22

Figure 3-7. Bulverde points . . . . . . . . . . . . . . . . . . . . . . . . 23

Figure 3-8. Castroville points . . . . . . . . . . . . . . . . . . . . . . . . 24

Figure 3-9. Clovis points . . . . . . . . . . . . . . . . . . . . . . . . . . 25

Figure 3-10. Possible Clovis base . . . . . . . . . . . . . . . . . . . . . . . 26

Figure 3-11. Proximal fragment of a Darl point . . . . . . . . . . . . . . . . . 26

Figure 3-12. Early Barbed point type . . . . . . . . . . . . . . . . . . . . . 26

Figure 3-13. Early Triangular points . . . . . . . . . . . . . . . . . . . . . 27

Figure 3-14. Ensor points . . . . . . . . . . . . . . . . . . . . . . . . . . 28

Figure 3-15. Evant points . . . . . . . . . . . . . . . . . . . . . . . . . . 28

Figure 3-16. Fairland points . . . . . . . . . . . . . . . . . . . . . . . . . 29

Figure 3-17. Frio points . . . . . . . . . . . . . . . . . . . . . . . . 30

Figure 3-18. Golondrina points . . . . . . . . . . . . . . . . . . . . . . . . 30

Figure 3-19. Hoxie point . . . . . . . . . . . . . . . . . . . . . . . . . . 31

Figure 3-20. Jetta points . . . . . . . . . . . . . . . . . . . . . . . . . . 31

Figure 3-21. Laguna points . . . . . . . . . . . . . . . . . . . . . . . . . 32

Figure 3-22. Lange points. . . . . . . . . . . . . . . . . . . . . . . . . . 33

Figure 3-23. Langtry points . . . . . . . . . . . . . . . . . . . . . . . . . 33

Figure 3-24. Marcos points . . . . . . . . . . . . . . . . . . . . . . . . 34

Figure 3-25. Marshall points . . . . . . . . . . . . . . . . . . . . . . . . . 35

Figure 3-26. Martindale points . . . . . . . . . . . . . . . . . . . . . . . . 35

Figure 3-27. Montell points . . . . . . . . . . . . . . . . . . . . . . . . 37

Figure 3-28. Nolan points . . . . . . . . . . . . . . . . . . . . . . . . . . 38

Figure 3-29. Pedernales points . . . . . . . . . . . . . . . . . . . . . . . . 39

Figure 3-30. St. Mary's Hall points. . . . . . . . . . . . . . . . . . . . . . . 40 
Figures and Table

Figure 3-31. Travis points . . . . . . . . . . . . . . . . . . . . . . . . . . 41

Figure 3-32. Uvalde/Gower points. . . . . . . . . . . . . . . . . . . . . . . 42

Figure 3-33. Val Verde-like point . . . . . . . . . . . . . . . . . . . . . . . 43

Figure 3-34. Williams points . . . . . . . . . . . . . . . . . . . 44

Figure 3-35. Wilson points. . . . . . . . . . . . . . . . . . . . . . . 44

Figure 3-36. Ten untyped dart points . . . . . . . . . . . . . . . . . . . . . 45

Figure 3-37. Arrow points . . . . . . . . . . . . . . . . . . . . . . . . . . 46

Figure 3-38. Multipurpose bifacial tool. . . . . . . . . . . . . . . . . . . . . 47

Figure 3-39. Large drills from $41 \mathrm{HY} 147$. . . . . . . . . . . . . . . . . . . . . . 48

Figure 3-40. Large end scraper and beveled knife fragment . . . . . . . . . . . . 48

Figure 3-41. Clear Fork adzes from 41HY147 . . . . . . . . . . . . . . . . . . . . 49

Figure 3-42. Adzes made on point fragments . . . . . . . . . . . . . . . . . . 51

Figure 3-43. Lunate uniface . . . . . . . . . . . . . . . . . . . . . . . . . 51

Figure 4-1. Calibrated results of radiocarbon dates from Spring Lake . . . . . . . 59

Figure 4-2. Clovis point . . . . . . . . . . . . . . . . . . . . . . . . . . 61

Figure 4-3. Clovis point . . . . . . . . . . . . . . . . . . . . . . . . . 61

Figure 4-4. Clovis base . . . . . . . . . . . . . . . . . . . . . . . . . . 61

Figure 4-5. Folsom point . . . . . . . . . . . . . . . . . . . . . . . . . . 62

Figure 4-6. Possible Folsom base . . . . . . . . . . . . . . . . . . . . . . 62

Figure 4-7. St. Mary's Hall point . . . . . . . . . . . . . . . . . . . . . . 62

Figure 4-8. St. Mary's Hall point . . . . . . . . . . . . . . . . . . . . . . 63

Figure 4-9. St. Mary's Hall point. . . . . . . . . . . . . . . . . . . . . . . 63

Figure 4-10. St. Mary's Hall point . . . . . . . . . . . . . . . . . . . . . . 64

Figure 4-11. St. Mary's Hall point . . . . . . . . . . . . . . . . . . . . . . 64

Figure 4-12. Golondrina point . . . . . . . . . . . . . . . . . . . . . . . . 65

Figure 4-13. Golondrina point . . . . . . . . . . . . . . . . . . . . . . . . 65

Figure 4-14. Angostura point fragment . . . . . . . . . . . . . . . . . . . . 65

Figure 4-15. Angostura point . . . . . . . . . . . . . . . . . . . . . . . . 66

Figure 4-16. Angostura point fragment . . . . . . . . . . . . . . . . . . . . 66

Figure 4-17. San Patrice point . . . . . . . . . . . . . . . . . . . . . . . . 66

Figure 4-18. Wilson point . . . . . . . . . . . . . . . . . . . . . . . 67

Figure 4-19. Wilson point. . . . . . . . . . . . . . . . . . . . . . . . . . 67

Figure 4-20. Wilson point . . . . . . . . . . . . . . . . . . . . . . . . . 67

Figure 4-21. Adze made on fragment of St. Mary's Hall point . . . . . . . . . . . 68

Figure 4-22. Clear Fork adze. . . . . . . . . . . . . . . . . . . . . . . . . 68

Figure 4-23. Clear Fork adze. . . . . . . . . . . . . . . . . . . . . . . . . 68

Figure 4-24. Miscellaneous adze . . . . . . . . . . . . . . . . . . . . . . . 69

Figure 4-25. Large drill . . . . . . . . . . . . . . . . . . . . . . . . . . . 69

Figure 4-26. Jetta point . . . . . . . . . . . . . . . . . . . . . . . . . . . 69

Figure 4-27. Jetta point . . . . . . . . . . . . . . . . . . . . . . . . . . 70 
Figure 4-28. Bell point . . . . . . . . . . . . . . . . . . . . . . . . . . . 70

Figure 4-29. Merrell point . . . . . . . . . . . . . . . . . . . . . . . . . . 70

Figure 4-30. Martindale point . . . . . . . . . . . . . . . . . . . . . . . . 71

Figure 4-31. Martindale point . . . . . . . . . . . . . . . . . . . . . . . . 71

Figure 4-32. Bandy point . . . . . . . . . . . . . . . . . . . . . . . . . . 71

Figure 4-33. Laguna point . . . . . . . . . . . . . . . . . . . . . . . . . . 72

Figure 4-34. Laguna point . . . . . . . . . . . . . . . . . . . . . . . . . . 72

Figure 4-35. Diagram of the time-ordering of Archaic periods . . . . . . . . . . . 73

Figure 4-36. Early Triangular point . . . . . . . . . . . . . . . . . . . . . . 74

Figure 4-37. Early Triangular point . . . . . . . . . . . . . . . . . . . . . . 74

Figure 4-38. Early Triangular point . . . . . . . . . . . . . . . . . . . . . . 74

Figure 4-39. Nolan point . . . . . . . . . . . . . . . . . . . . . . . . . . 75

Figure 4-40. Nolan point . . . . . . . . . . . . . . . . . . . . . . . . . . 75

Figure 4-41. Travis point . . . . . . . . . . . . . . . . . . . . . . . . . . 75

Figure 4-42. Travis point . . . . . . . . . . . . . . . . . . . . . . . . . . 76

Figure 4-43. Bulverde point . . . . . . . . . . . . . . . . . . . . . . . . . 76

Figure 4-44. Bulverde point . . . . . . . . . . . . . . . . . . . . . . . . . 76

Figure 4-45. Pedernales point . . . . . . . . . . . . . . . . . . . . . . . . 77

Figure 4-46. Pedernales point . . . . . . . . . . . . . . . . . . . . . . . . 77

Figure 4-47. Pedernales point . . . . . . . . . . . . . . . . . . . . . . . . 77

Figure 4-48. Montell point. . . . . . . . . . . . . . . . . . . . . . . . . . 78

Figure 4-49. Montell point. . . . . . . . . . . . . . . . . . . . . . . . . . 78

Figure 4-50. Montell point. . . . . . . . . . . . . . . . . . . . . . . . . . 78

Figure 4-51. Castroville point . . . . . . . . . . . . . . . . . . . . . . . . 79

Figure 4-52. Castroville point . . . . . . . . . . . . . . . . . . . . . . . . 79

Figure 4-53. Castroville point . . . . . . . . . . . . . . . . . . . . . . . . 79

Figure 4-54. Marcos point . . . . . . . . . . . . . . . . . . . . . . . . . . 80

Figure 4-55. Marcos point.. . . . . . . . . . . . . . . . . . . . . . . . . . 80

Figure 4-56. Marcos point . . . . . . . . . . . . . . . . . . . . . . . . . . 80

Figure 4-57. Ensor point . . . . . . . . . . . . . . . . . . . . . . . . . . 81

Figure 4-58. Ensor point . . . . . . . . . . . . . . . . . . . . . . . . . . 81

Figure 4-59. Fairland point . . . . . . . . . . . . . . . . . . . . . . . . . 81

Figure 4-60. Scallorn point . . . . . . . . . . . . . . . . . . . . . . . . . 82

Figure 4-61. Edwards point . . . . . . . . . . . . . . . . . . . . . . . . . 82

Figure 4-62. Perdiz point. . . . . . . . . . . . . . . . . . . . . . . . . . . 83

Table 4-1. Cultural chronology for Central Texas . . . . . . . . . . . . . . . 57 



\begin{abstract}
Underwater investigations conducted at Spring Lake in the 1970s and 1980s by the late Dr. Joel Shiner contributed significantly to our overall understanding of the archaeological record in Central Texas and its relationship to prehistory in North America. His work not only produced abundant evidence for early Paleoindian occupations associated with freshwater spring sites but also helped to demonstrate a nearly continuous sequence of occupation spanning more than 13,000 years, from Clovis times through the Spanish Colonial era and into the historic period. Using field notes and correspondences held in the records and collections repository at the Center for Archaeological Studies, Texas State University-San Marcos, we reconstruct a history of Shiner's work at the lake and present new analytic data about the temporally diagnostic artifacts comprising the 41HY147 collection. Results are discussed in the context of regional findings elsewhere. In addition to detailed descriptions of this collection, we have given special attention to preparing high quality illustrations of many of these artifacts, most of which are presented to the public for the first time in this report. Publication of the findings from this early research at Spring Lake illustrates the significance of this site in the cultural landscape, and provides a sound basis for the ongoing and future scientific investigations here.
\end{abstract}

The report was undertaken as an alternative mitigation measure to help offset potentially unavoidable impacts to important cultural resources at Spring Lake that may have occurred as part of the recently completed Section 206 aquatic ecosystem restoration project at the headwaters of the San Marcos River conducted jointly by the United States Army Corps of Engineers and Texas State University. 



\title{
Chapter 1 \\ Introduction
}

\author{
Jon C. Lohse and Carole A. Leezer
}

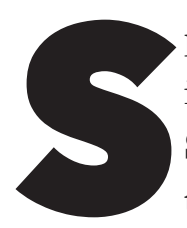

pring Lake is an artificial lake, located near the headwaters of the San Marcos River in present-day Hays County, Texas (Figure 1-1). The lake is the site of San Marcos Springs, a large artesian outflow comprising some 200 springs that emanate from the Edwards Aquifer along the Balcones Escarpment (Figure 1-2). It was created in 1849, when Edward Burleson, an early Texas soldier and statesman and one of the founders of the City of San Marcos, built a dam across the river about one-half mile downstream from the springs (Stovall et al. 1986; Jenkins and Kesselus 1990).

During the past several decades, archaeologists have investigated the prehistoric occupation of this area, both above and below the waters of Spring Lake. On-land excavations during the

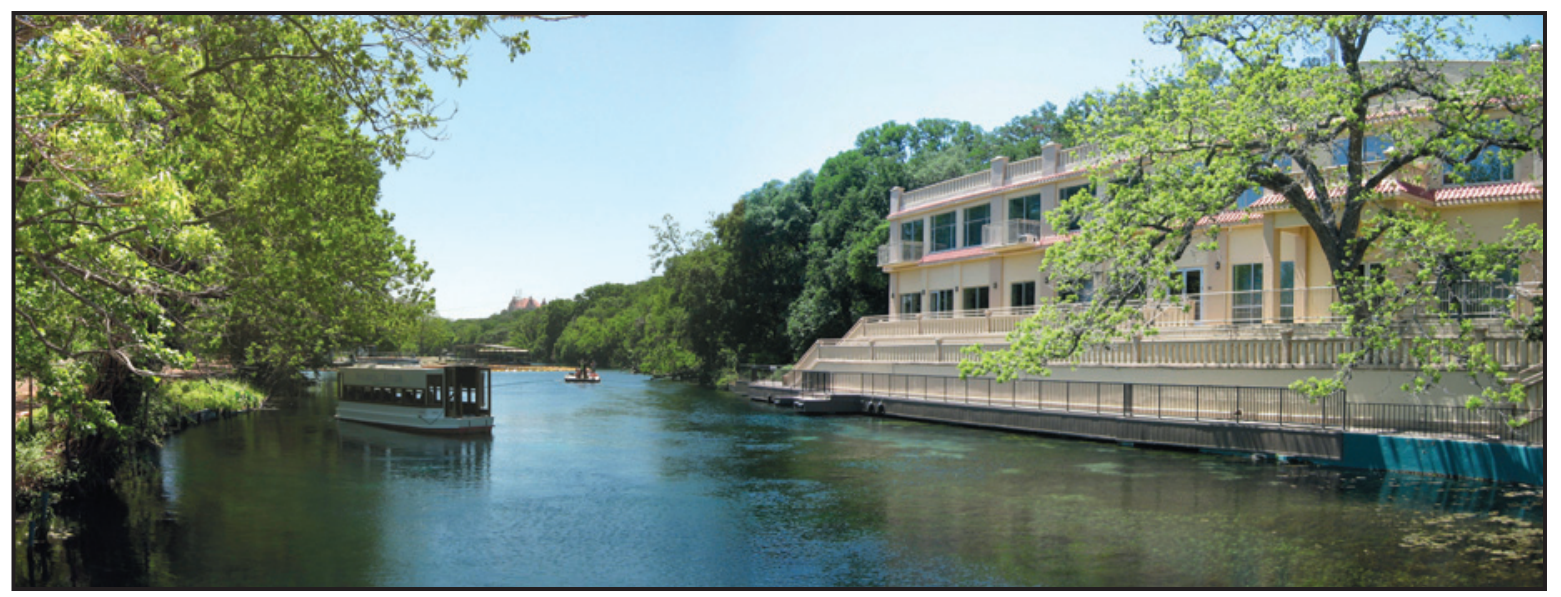

Figure 1-1. A panoramic photomosaic of Spring Lake, looking to the southwest. The Balcones Escarpment looms over the western lakeshore, behind the old Aquarena Springs Hotel (at right), now home to the Meadows Center for Water and the Environment, of Texas State University-San Marcos. Photo by David M. Yelacic. 


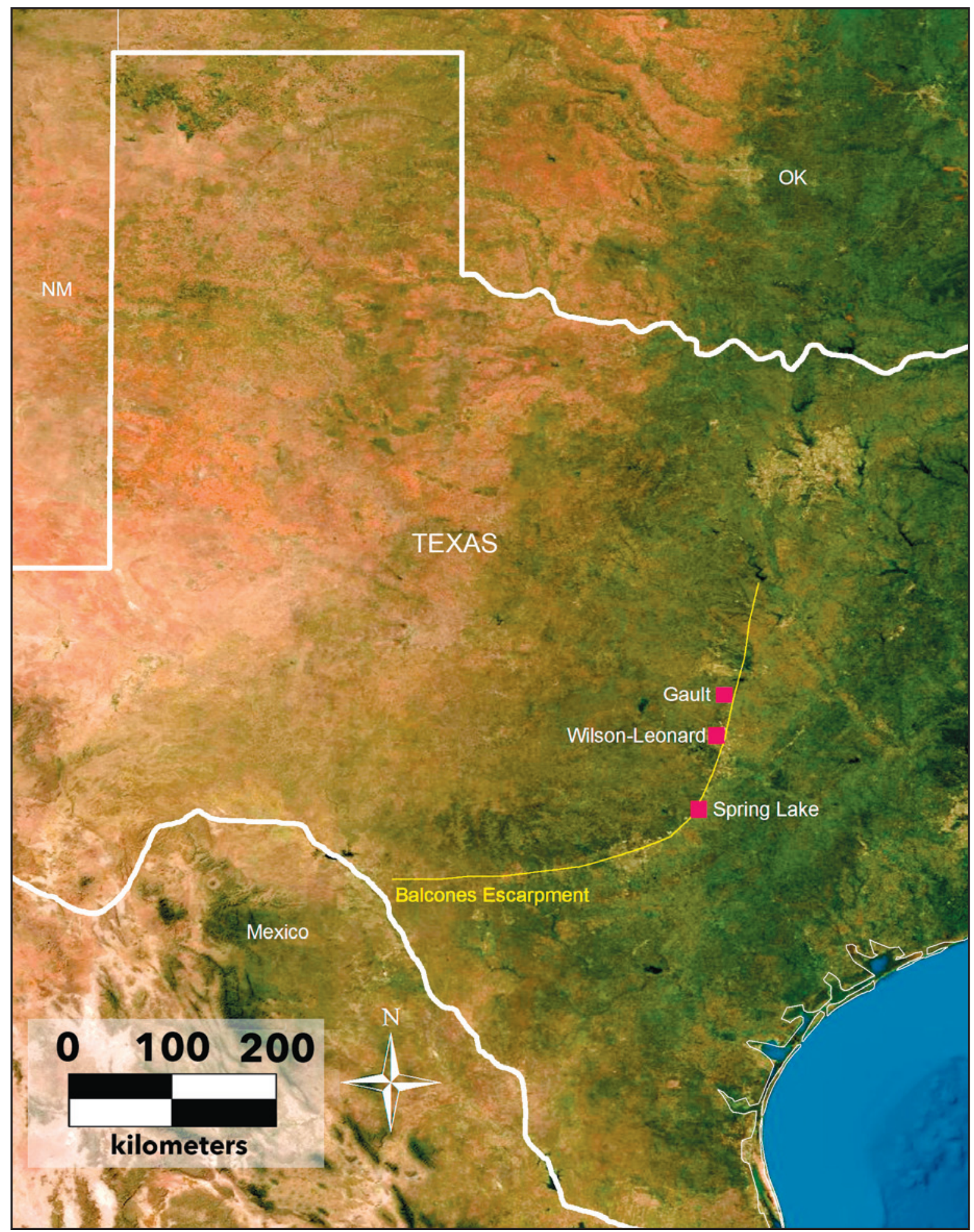

Figure 1-2. Regional map of Central Texas showing the Balcones Escarpment and sites mentioned in the text. 
1980s were carried out by Texas State University-San Marcos (University) archaeological field schools under the direction of Dr. James Garber and others (Garber and Orloff 1984; Garber et al. 1983). During the late 1970s and 1980s, underwater investigations were conducted at Spring Lake by the late Dr. Joel L. Shiner and Paul Takac of Southern Methodist University (SMU). This report pertains to these underwater investigations.

In 1978, in his search for evidence of early human occupation at archaeological sites associated with freshwater springs in Central Texas, Shiner initiated underwater excavations in the lake. Although he gave some attention to other localities in the region, most of his research was conducted at Spring Lake, and his work there, especially at 41HY147, perhaps represents Shiner's most important contribution to local, regional, and North American archaeology.

With permission from the management of the then Aquarena Springs amusement park, Shiner initiated and oversaw several investigations at 41HY147. His work was never completely reported or presented to the scientific community or general public although he presented some interpretations of the site based on highlights of his findings in an article in Plains Anthropologist (Shiner 1983). Those interpretations were not well received by the academic archaeological community (Johnson and Holliday 1984; Shiner 1984a). Regardless of the reservations expressed in published critiques of his work, however, Shiner succeeded in drawing attention to the close relationship between the many freshwater springs along the eastern margin of the Balcones Escarpment and long-term human occupation in Texas, beginning at least in Clovis times and continuing through the Late Prehistoric. The region is characterized by numerous archaeological deposits and multicomponent sites, attesting to a long cultural continuity and ostensibly to high regional population densities during prehistoric times. Among the largest clusters of such sites is a group constellating around San Marcos Springs (now Spring Lake): State Antiquities Landmarks 41HY147, 41HY160, 41HY161, and 41HY165. Most of Shiner's work was carried out at 41HY147 and 41HY161.

In retrospect, the geologic context of Shiner's excavations at $41 \mathrm{HY} 147$ was less than ideal. Compared with the apparent time depth of the cultural remains at the site, the setting includes relatively shallow deposits intermixed with heavy gravels. Although it has been submerged below the lake since the 1840 s, this site is quite close to the original stream channel of the San Marcos River. Added to smaller-grain alluvial gravels are a number of sharp-edged cobbles and boulders that undoubtedly through time have cascaded down the steep face of the Balcones Escarpment, which rises directly over the site at the western margin of Spring Lake. In his notes, Shiner referred to the $41 \mathrm{HY} 147$ locality as a low terrace and described the timeordering of distinctively styled artifacts. A review of excavation levels from which projectile points belonging to different time periods were recovered, however, reveals that most styles were fairly evenly mixed throughout the deposit. Although some structure to this deposit is apparent (described in Chapter 2 from Shiner's notes and correspondences), the context has 


\section{Chapter 1}

proven to be problematic for purposes of distinguishing discrete time periods in the physical stratigraphy.

The significance of this obscure stratigraphy to the overall assemblage from $41 \mathrm{HY} 147$ is that, because they come from poorly defined contexts, most of the artifacts have only marginal potential to provide evidence of specific technological activities that took place at this site during the long period of its occupation. Nevertheless, the collection of stylistically distinctive projectile points and other tools does provide an extremely important record of the general time periods represented in the archaeological record at Spring Lake. When compared with the regional chronological sequence, each of the major archaeological time periods defined for Central Texas is represented in this remarkable assemblage. This fact, realized early on by Shiner and Garber, has provided the basis for the anecdotal description of Spring Lake as the longest continuously occupied site in North America. The claim is of course difficult to prove scientifically, inasmuch as it depends on incomplete knowledge from other sites in North America. However, with an occupation spanning more than 13,000 years, from Clovis times all the way through the prehistoric sequence to the Spanish Colonial era and into the Historic period, Spring Lake certainly contains one of the longest, if not the longest, continuous cultural sequence in Texas and perhaps beyond. This report presents the Spring Lake assemblage of time-diagnostic points and other selected artifacts in clearly illustrated and technological detail. Comparative discussion of some specimens helps to contextualize this assemblage in relation to other documented sites.

The Center for Archaeological Studies at Texas State University (CAS) has undertaken this report as part of an alternative strategy for mitigating possible adverse effects to the archaeological deposits at Spring Lake that may have occurred as a result of the recently completely Section 206 aquatic ecosystem restoration project at the headwaters of the San Marcos River. That undertaking was jointly conducted by the United States Army Corps of Engineers and Texas State University. Early in the archaeological planning process, CAS recommended and the Corps agreed that attention to the then-unpublished findings from the Spring Lake site, which included a significant amount of information regarding the early history of occupation in the study area, was a preferred course of action over designing and carrying out a new set of excavations. This report, together with a finalized account of excavations conducted at nearby $41 \mathrm{HY} 165$ in the mid-1990s (Leezer 2013) and archaeological monitoring of the restoration work while it was underway (Leezer et al. 2012) serves to mitigate the effect of this restoration project on important cultural resources, including the archaeological record at Spring Lake.

This report is intended to be nontechnical in nature, thereby making it accessible to the interested public. We anticipate that by providing a detailed and well-illustrated summary of Shiner's work and the results of his investigations, an important gap will be filled in terms of how archaeologists as well as the public understand, view, and appreciate this remarkable cultural resource. 


\title{
Chapter 2 \\ Underwater Excavations at 41 HY147
}

\author{
Jacob Hooge, Carole Leezer, Fritz Hanselmann, and Jon C. Lohse
}

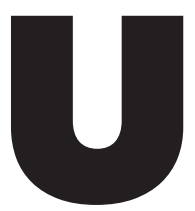

nderwater archaeological research in the area of the San Marcos Springs

commenced in the summer of 1978 after a local scuba instructor informed Dr. Joel Shiner of SMU about the many artifacts being found on the bottom of the San Marcos River (Figure 2-1). During the ensuing years, excavation, reconnaissance, and collecting produced an assemblage of more than 100,000 culturally modified pieces of stone debris gathered from various contexts below the surface of Spring Lake. Although none of the research was ever fully reported, the results, some of which are presented in fuller

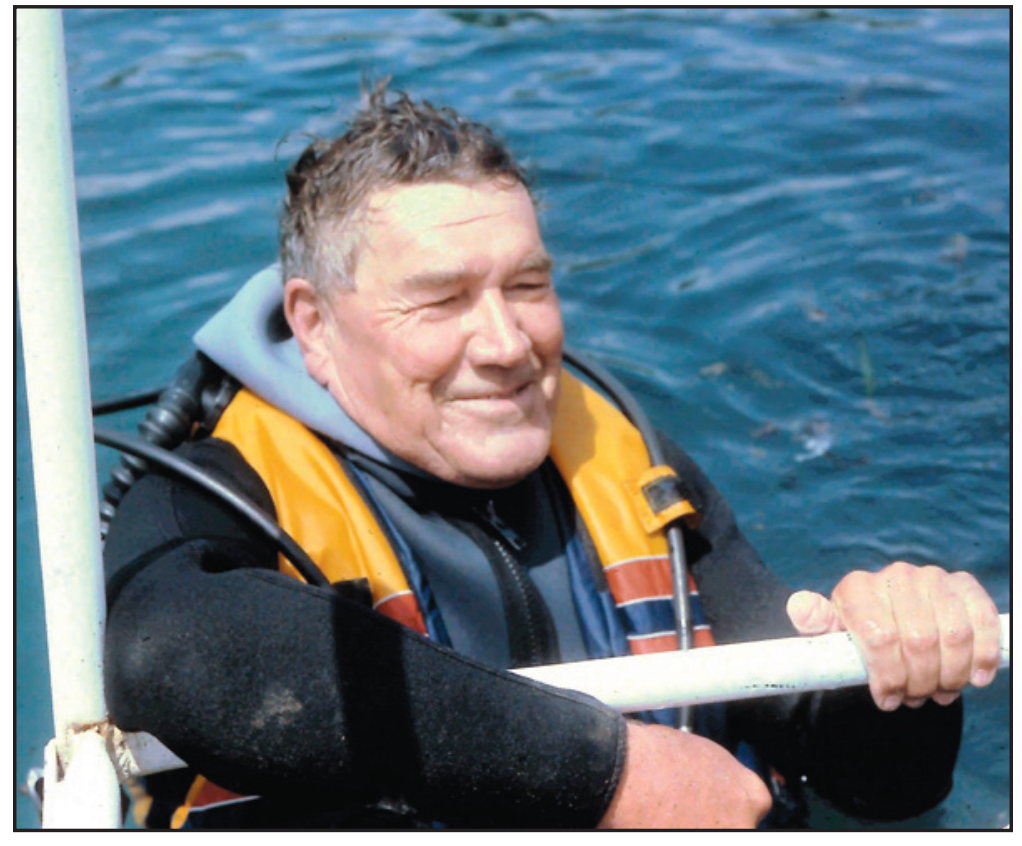

Figure 2-1. Joel Shiner on break from excavations at Spring Lake. detail in Chapter 3, clearly indicate that a significant span of prehistoric time is represented at this extraordinary site. Indeed, the remains recovered by Shiner and his colleagues were so promising that, in the early 1990s, SMU doctoral student Paul Takac spent a couple of years planning follow-up research for his dissertation there.

Although his work never advanced beyond the planning stages, in presentations at two 
archaeological conferences Takac explored the role of Spring Lake in regional huntergatherer cultural systems (Takac 1991b and 1992). Using correspondence, notes, and other records on file at the CAS, this chapter reconstructs as clearly as possible how Shiner's early work began and discusses Takac's work and the theoretical framework of his research plan. Unless otherwise noted, all of the details of this work are included in unpublished notes, correspondence, and project records.

\title{
SHINER's WORK
}

Based on early, oral reports, Shiner believed that the Spring Lake locality seemed likely to hold evidence for early prehistoric human occupation of the region. In a 1978 letter to the Center for Field Research, of Belmont, Massachusetts, he proposed a research project at Aquarena Springs.

\begin{abstract}
The...idea is an underwater investigation of Indian campsites at the giant Aquarena Springs, San Marcos, Texas. Thousands of flint artifacts have been found in the outflow stream, but the area around the spring has not been examined. An early dam first below the spring raised the water level several feet and apparently inundated many prehistoric sites. Before any substantial work could be done, I would have to make a brief feasibility survey. Four to six volunteers could be used (Shiner to N. Scott, letter, September 14, 1978, Shiner Papers, Center for Archaeological Studies, Texas State University-San Marcos).
\end{abstract}

In September 1978, Shiner collected a small sample of artifacts while diving just below the spillway of the Ice House Dam, in what is now part of a site designated as State Antiquities Landmark 41HY161. Soon thereafter, he received permission from the management of the Aquarena Springs amusement park to conduct a search for the source of those artifacts, which he believed to be sites within Spring Lake and the park.

In October 1978, Shiner requested permission from the Texas Historical Commission (THC) to study cultural materials exposed in secondary contexts on the lake and river bottom. According to the original permit application, Shiner planned to classify the prehistoric cultural sequence of the area and to identify evidence for what he termed "religious-magical offerings." He proposed to accomplish these tasks by collecting sediment cores from the south shore of the lake in order to determine the location of the pre-dam stream bank and by inspecting the area of the springs for utilitarian and eccentric flints. In spite of this initial plan, there is no record that any cores were ever taken (there also is no evidence that eccentric flints were ever found). However, by mid-November 1978, Shiner was searching for the original north stream bank by removing the lacustrine sediment cover from an area >90 m (300 ft) west of the area of the lake known today as Deep Hole (Figure 2-2). The morphology of the shallow lake basin suggests that the north shore, immediately adjacent to the relatively steep face of the Balcones Escarpment, would be characterized by much less extensive deposits than would be present along the south shore, closer to the peninsula of dry land separating most of Spring Lake from the lower Sink Creek channel. However, the area of Deep Hole would also have been farther removed from and out of the way of the daily underwater performances then taking place at the Aquarena Springs park. 


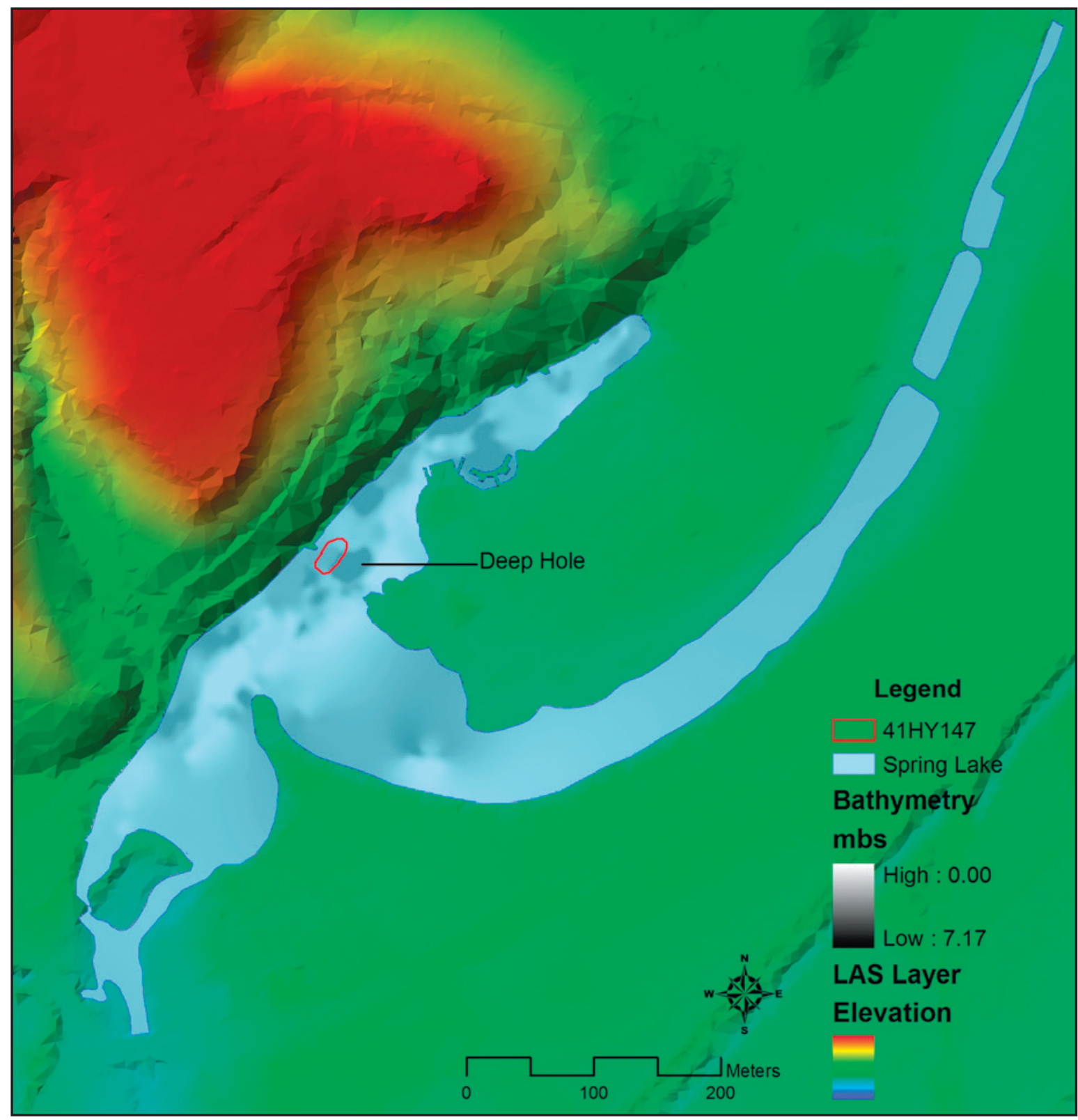

Figure 2-2. LIDAR and bathymetric map of Spring Lake and nearby areas, showing location of $41 \mathrm{HY} 147$ in relation to Deep Hole. Site 41HY147, also known as the Terrace Locality, was the location of most of Shiner's underwater excavations. Map by David M. Yelacic, 2012.

In a letter dated July 23, 1979, Shiner reported the results of his initial excavations to the coordinator of nominations for National Register programs of the THC. In this letter, Shiner stated that he had excavated an area of more than $12 \times 10 \mathrm{~m}$ at a location he called the Terrace Locality, which he believed to be an underwater terrace lying adjacent to the lake's northwestern bank. In addition, he said he had closely observed two other areas of the lake. 


\section{Chapter 2}

One of these areas is near the mouth of Sink Creek where it enters Spring Lake; this is where most of the sediments resulting from installation of the amusement park's second submerged theater had been deposited in 1972. These secondary deposits are shallow enough to make it possible for them to be screened by workers simply walking out into the lake and sifting sediments through a $1 / 4$-in mesh with a shovel (Figure 2-3). The other area, which remains unidentified, was related to construction at the historic hotel situated on the north edge of the lake.

The list of artifacts Shiner and his team recovered from these three localities is impressive in terms of the time span of prehistoric occupation represented. Shiner identified Clovis, Angostura, Nolan, Martindale, and Pedernales points from the Terrace Locality; Clovis, Plainview (in current classifications, most likely St. Mary's Hall), San Patrice, Bulverde, and Pedernales points from the submarine theater sediment (redeposited near the confluence of Sink Creek and Spring Lake); and large numbers of Nolan, Bulverde, Pedernales, and other Middle and Late Archaic points from the early hotel construction (unidentified location).

Shiner was sufficiently encouraged by the results of this initial research that he planned and carried out a series of intensive excavations at the Terrace Locality beginning in the spring of 1979 and continuing through the summer of 1984 (Shiner 1981). Work, conducted on occasional weekends, was performed by students of his underwater archaeology diver training courses (Figure 2-4). Few excavation records exist from this phase of research. However, existing level forms suggest that an expanse totaling at least $79 \mathrm{~m}^{2}$, concentrated in two major clusters or areas, were excavated to a depth of three to four levels. A grid system was established to define excavation units, with letters (A through Z) defining one axis and numbers defining the other. The grid appears to have been expanded after it was established, as some units bear a "negative" letter designation (e.g., -A, -B,

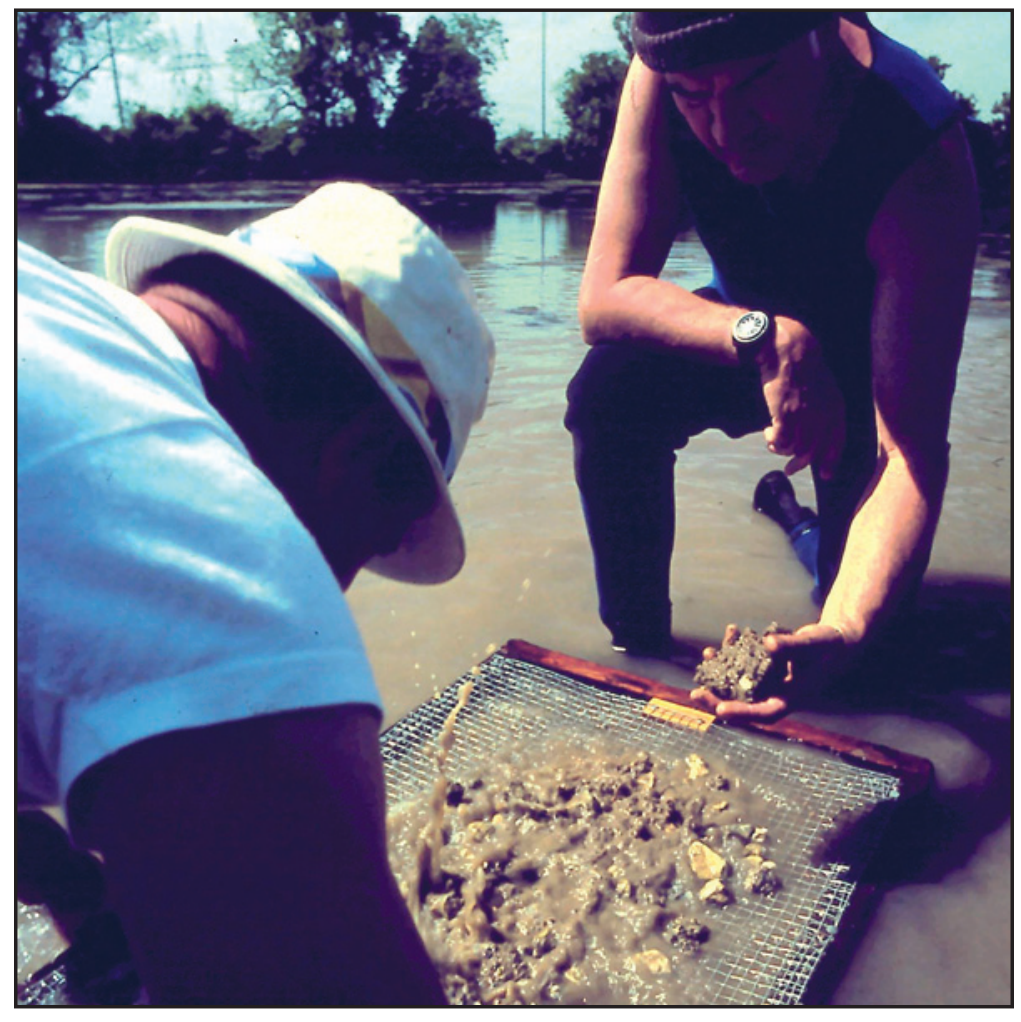

Figure 2-3. Joel Shiner and an unidentified assistant screening redeposited sediments at the confluence of Sink Creek and Spring Lake. 
etc.). Unfortunately, no records indicate exactly how deep the excavation levels were, and it is unknown whether each layer was of an arbitrarily uniform thickness, or whether the thickness of each level may have corresponded to observable stratigraphy. Later excavations were conducted utilizing stratigraphic levels within the apparent terrace, or at least made note of stratigraphic changes in the sediments.

In the fall of 1980, Shiner collected samples for pollen analysis, which was performed by Anne Woosley at SMU. The samples submitted for analysis were extracted from levels described as:

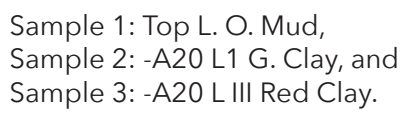

Woosley's brief interpretation (Woosley to Shiner, letter, October 1, 1980, Shiner Papers, Center for Archaeological Studies, Texas State University-San Marcos) explained that the homogeneity of pollen grains found in the samples suggested that mixing had possibly occurred either within the sediments or in the water.

Not long after beginning his investigations, in Shiner's first major publication based on his Spring Lake excavations (Shiner 1981), he described a typical Archaic assemblage similar to those in sites at Canyon Lake and Stillhouse Hollow Reservoir, both of which by then had been

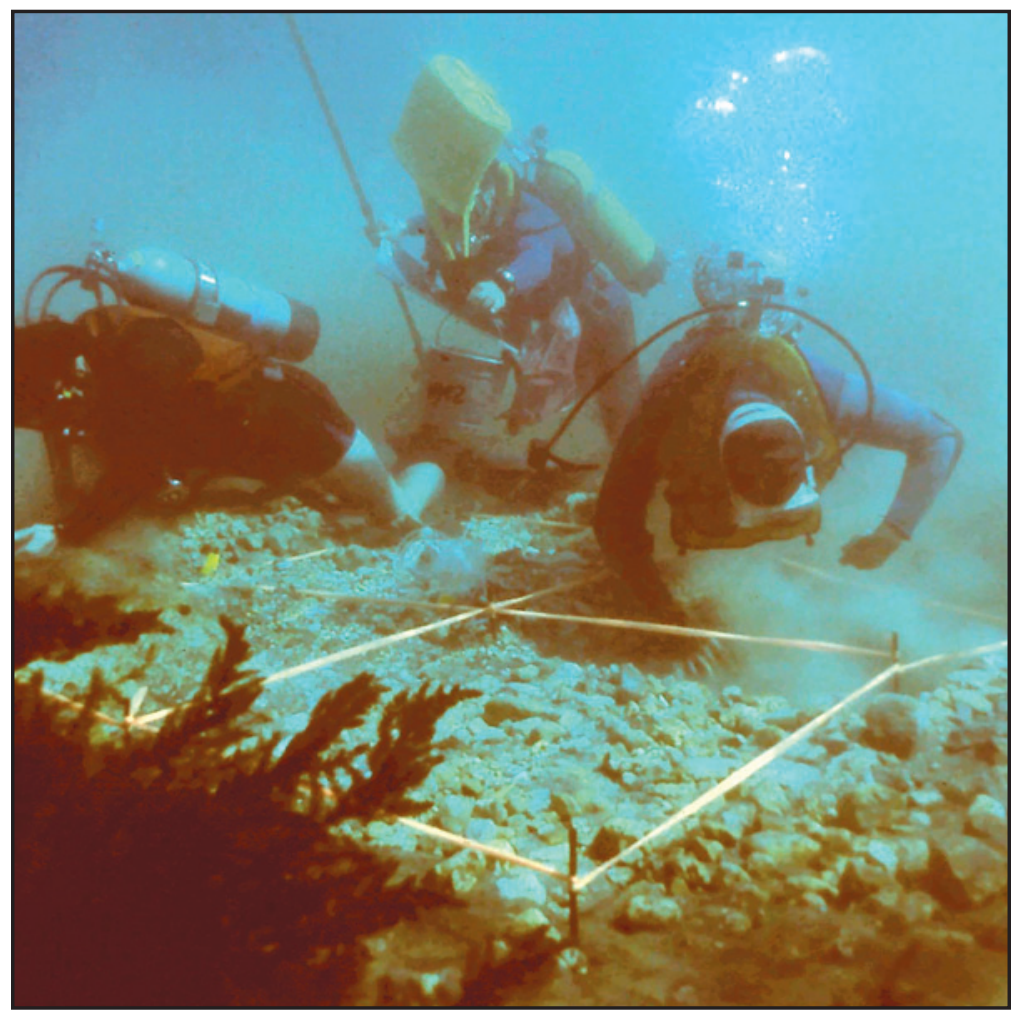

Figure 2-4. Divers excavating at the Terrace Locality. published and were available for comparative discussions (Johnson et al. 1962; Sorrow et al. 1967). Seemingly in an effort to reinforce what he had referred to as the religious-magic aspect of his research design, he also mentioned numerous socalled exotic stones, alligator gar scales, and chert sourced from approximately $80-120$ $\mathrm{km}$ away (50-75 mi). Shiner presented plans to study the immediate vicinity of each spring to test his model for "aboriginal veneration of the springs" which "includes exotic or eccentric offerings and an absence of offensive garbage" (Shiner 1981:203). 


\section{Chapter 2}

In these plans, he proposed additional research on the analysis of village activity, such as food processing, craft production, and trash disposal, and he foresaw opportunities to employ experimental equipment in underwater excavation and photography. Much of his early academic focus seems to have centered on the ideological relationship between successive occupations and the springs. Specifically, Shiner proposed that deposits of exotic and eccentric materials along with the absence of so-called offensive garbage supported his model of aboriginal veneration of the springs.

Later, Shiner (1983) expanded upon his early model by incorporating material found in several privately owned collections from other Central Texas spring localities. He argued that the abundance of lanceolate points and the presence of mammoth and mastodon tooth fragments in the absence of long bones at Spring Lake showed these spring sites served as Paleoindian base camps. The archaeological concept of base camps describes the main camp or central place to which residentially mobile hunter-gatherer bands would have periodically returned during periods or phases of social aggregation in their annual settlement cycles. The concept is important to many common models of prehistoric forager settlement and subsistence practices (e.g. Binford 1980). However, based on the volume and density of cultural remains at Spring Lake and the abundance of local resources capable of supporting small groups, Shiner (1983) suggested that spring sites like Spring Lake may have been associated with a nearly sedentary mode of existence. It was this interpretation in particular that conflicted with thencurrent archaeological models of hunter-gatherer behavior (Johnson and Holiday 1984).

Shiner conducted his first extended field season in the summer of 1984, with the support of a grant from the Institute for the Study of Earth and Man at SMU, which allowed for the excavation of a $5 \times 5 \mathrm{~m}$ pit in the Terrace Locality. Starting in 1984 and up until his death in 1988, Shiner expanded the Terrace Locality excavation, which eventually covered an area of at least 46 square meters, excavated to a maximum depth of 1-2 m. In July 1985, during the final phase of his research, Shiner conducted one additional extended field season.

\section{Making Sense of the Terrace Locality}

Shiner conducted investigations at different levels of intensity at various locations across Spring Lake, including an area immediately below the Ice House spillway. The Terrace Locality (41HY147), however, represents by far his most intensive focus and was the source from which he recovered the greatest number of artifacts. The documentation of his research is incomplete, but some of the archaeological context of his investigations at the Terrace Locality can be reconstructed from notes and records. For example, unit and level designations of provenience were written directly onto the surface of many of the artifacts. Although few formal maps, field journal entries, or level forms are available, Shiner recorded some observations about the setting, and its geomorphic and stratigraphic character. These observations help to contextualize the results of much of his work, including the recovered artifacts. 
In his 1983 publication, Shiner explains the stratigraphy of an unstated location, presumably within the Terrace Locality, as consisting of three components: Levels 1,2 , and 3. Level 1 is a $20-30-\mathrm{cm}$ stratum of grey clay containing Archaic projectile points. Level 2, described as a 10-20 cm thick red sand layer, contains shouldered and lanceolate (Early Archaic and Paleoindian) projectile points. Level 3 is a red clay layer containing megafauna and Paleoindian projectile points. All three strata contain limestone boulders (Shiner 1983).

Fragmentary notes and several profile sketches of the Terrace Locality hint at the presence of a more intricate stratigraphy than Shiner presented in the 1983 publication. Reconstruction of these records reveals a more complex deposit containing as many as nine stratigraphic units, labeled Levels 1, 2, 3, 4, 5, 6a, 6b, 7a, and 7b (Figure 2-5). Although not specifically documented as such, Level 1 was probably what Shiner considered the pre-dam 1840 surface, which he observed as having a non-sloping upper boundary. In Figure 2-5, Level 1 is labeled "coarse gravel." Level 2 was not specifically listed, but is labeled "red clay." Level 3 was described as a black clay layer with a non-sloping upper boundary, but with a northwest-

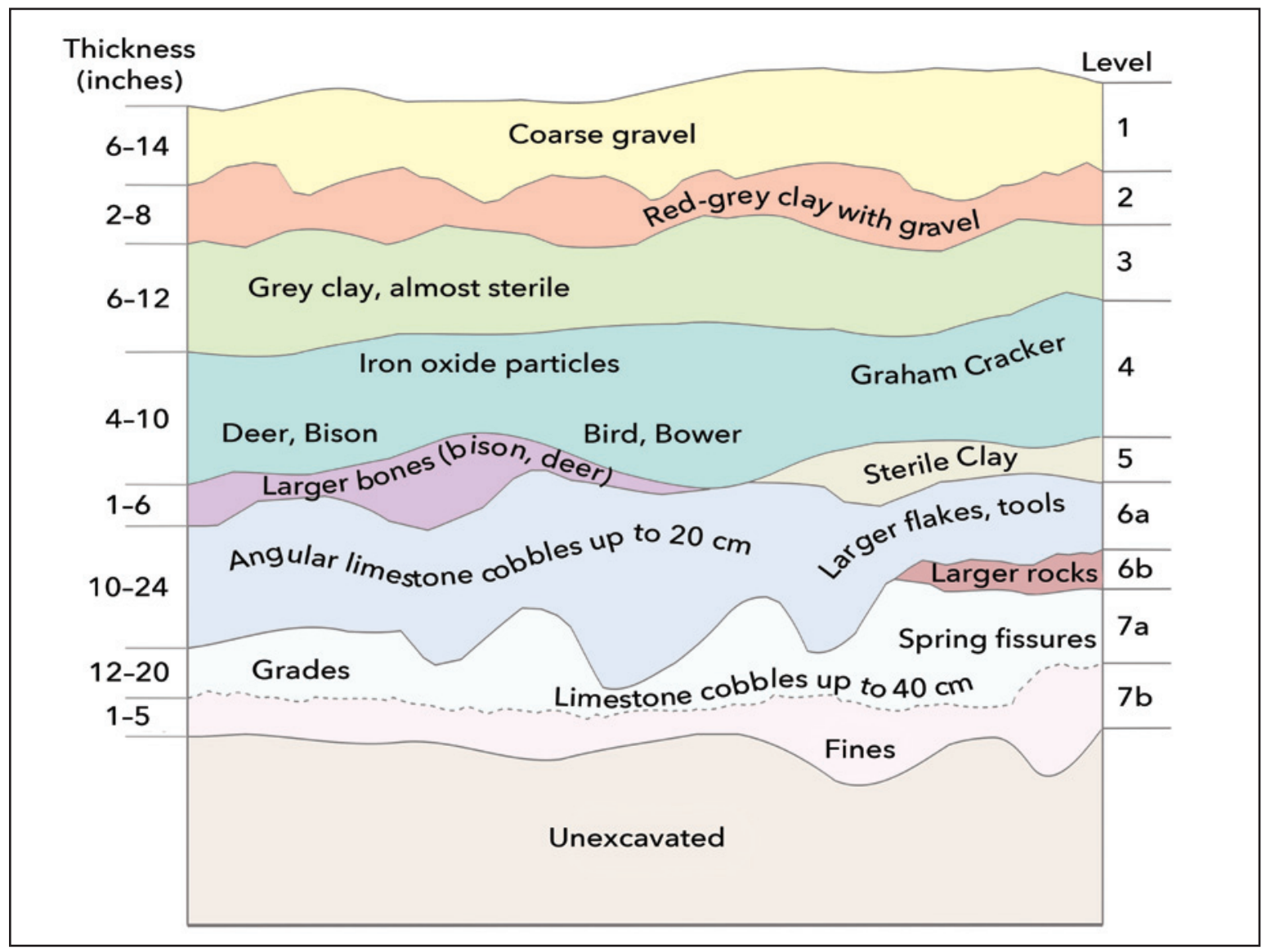

Figure 2-5. Profile of northeast wall of Terrace Locality excavation, reconstructed from Joel Shiner's sketches and notes. 


\section{Chapter 2}

southeast sloping lower boundary, 8-10 in thick. Level 4 was described as poorly sorted gravel interbedded with culturally sterile red clay sloping northwest to southeast. Level 5 consisted of multiple lenses of small gravels and yellow-brown clay with a total thickness of $46-51 \mathrm{~cm}$ (18-20 in). According to other notes from the excavation, this level contained mammoth and mastodon tooth fragments along with Paleoindian and Archaic projectile points. The bottom of Level 5 was described as clay with sand-sized inclusions, sloping northwest to southeast, 0-7.5 cm (0-3 in) thick with a maximum depth of 109-119 cm (43-47 in) below the 1840 surface. The deepest level, Upper Level 6, was described in notes as a "colloidal material, more gray than yellow" (notes and sketches, ca. 1982, Shiner Papers, Center for Archaeological Studies, Texas State University-San Marcos).

Although they are informative, the notes and sketches from which the above stratigraphic descriptions were derived are not representative of the work of a trained soil scientist. For instance, rock and gravel inclusions were commonly described in Shiner's records as "basketball-sized" or "goose egg-sized." In view of these deficiencies, caution must be exercised when scientifically precise terms do appear, such as when Shiner uses the term "colloidal material." Schaetzl and Anderson (2005) define colloids as being composed of very fine particles (0.1-0.001 microns). Although Shiner probably did not intend to convey the exact size of Upper Level 6 particles, he may very well have observed much finer clay than was seen in previous levels. Very fine, organic-rich clay does occur interbedded with gravels in the vicinity of the submerged theater (Leezer et al. 2011). A tentative interpretation that could be made about the above stratigraphic description is that the Terrace Locality may indeed contain one or more buried soils capped or perhaps truncated by a gravel bar. The color series seen in Levels 3,4 , and 5 is characteristic of a developed soil with $\mathrm{A}, \mathrm{B}$, and $\mathrm{Bk}$ or possibly $\mathrm{C}$ horizonation, respectively.

It is important to note that gravels of varying size, as well as possible truncated soils, occur in all of Shiner's major stratigraphic levels (heavy gravels are visible on the surface of the Terrace Locality excavation in Figure 2-4). Additionally, in spite of some of the anecdotal accounts of the time-ordering of important point styles from the excavation, an analysis of the distribution of time-diagnostic types by level indicates that most major time periods seem to occur throughout the excavation column. For example, Wilson and St. Mary's Hall (Paleoindian); Angostura and Uvalde/Gower (Early Archaic); Nolan (Middle Archaic); and Pedernales, Lange, Montell, Castroville, Marcos, Ensor, and Frio (Late Archaic) specimens were all recovered from excavation Level 5. Unfortunately, it is impossible to correlate this excavation level with the reconstructed stratigraphy described above. Another more likely interpretation is that this depositional sequence accumulated after Late Archaic times (time markers from this period occur in some of the lowest levels). However, even in this scenario, any time-ordering that may in fact be present at this locality would not be of fine enough resolution to be substantially useful for archaeological interpretations. The most reasonable 
conclusion based on available information is that the Terrace Locality probably contains cultural deposits that have been mixed through natural processes.

Considering the shallow depth of sediments in the Terrace Locality and the fact that most of the Central Texas cultural chronology is represented here, this location probably represents a series of gravel bar-type deposits that through time built up adjacent to the main channel of the uppermost San Marcos River before it was dammed in the 1840s. The artifacts present here undoubtedly all came from immediately surrounding deposits and are likely to have been washed into place through a series of flooding events occurring during the millennia of occupation. Nevertheless, in spite of what seems to be poor stratigraphic context for this assemblage, the Terrace Locality material is important archaeologically because it provides the best general indication so far available of the overall time depth of human occupation at Spring Lake.

\section{TAKAC's WORK}

After Shiner's death in 1988, SMU graduate student Paul Takac began working with Shiner's collections and notes in 1990 in order to complete Shiner's analysis and to conduct further excavation (Takac 1991a) as part of his doctoral dissertation. Takac began investigations at Spring Lake with three goals: (1) to generate a map of the Terrace deposits, (2) to stabilize the walls of Shiner's excavation units and remove slumped sediments, and (3) to produce a bathymetric map of the lake (Takac 1991a). Takac hoped to test some of the important aspects of Shiner's model, which Takac referred to as the "home base model." Takac sought to collect and evaluate an independent series of data that could be used to study local chert sources, to reconstruct aspects of the ancient environment, to study use of the site over time by huntergatherers, and to evaluate the spatial patterning of cultural deposits that were present.

Takac began his efforts by mapping the depth of the gravel deposit Shiner had presumed to be the 1840 surface across a $40 \times 40 \mathrm{~m}$ area using a floating grid and a metal sounding pole. Shiner had inferred that the top of the gravels represented the approximate top of deposits in the lake prior to the 1840s era dam. While removing sediments from the Terrace Locality, Takac (1991b) noted that modern trash was found in silt very near the gravel, which seemed to verify Shiner's presumption that the gravel represented the best approximation of the 1840 surface. However, in other areas where he probed, Takac was unable to reach gravel.

In 1991, Takac attempted to map more of the lake bottom with the use of groundpenetrating radar (Figure 2-6). The survey, performed under contract by Envirometrics Inc., yielded limited results (Takac 1991b). Takac cited as causes for the failure of the survey problems with large amount of dissolved calcium carbonate in the spring water, the gradual nature of the interface between the water column and the lake bottom, and the amount of clay in bottom sediments (Takac 1991b).

Takac intended to continue research based on Shiner's Paleoindian home base model, but with modifications (Takac 1991a, 1991b, 1992). For example, Takac presumed that Paleoindian 
populations at Spring Lake were participating in a broad-spectrum subsistence strategy inasmuch as no single resource would have been available in quantities sufficient to sustain year-round occupation at the site. But Takac also recognized, as had Shiner, that the eastern margins of the Central Texas region represented an unusual ecotonal setting during the late Pleistocene, with close proximity to all the resources of the plains, forest, and prairie grassland ecosystems. Furthermore, the abundance of high-quality lithic resources in Central Texas would have been another attractant to Paleoindian populations (Takac 1992).

Rather than simply arguing for a near-sedentary hunter-gatherer existence based solely on numbers of projectile points and megafauna tooth fragments, Takac used hydrological and paleoenvironmental evidence from Spring Lake to formulate a concept of cultural adaptations that prehistoric groups may have made to this environment by applying these local conditions to Walter Taylor's theoretical construct of tethered nomadism.

Working in Coahuila, Taylor (1964) had devised the concept of tethered nomadism to explain site distributions in arid regions where people were tied to isolated water sources while foraging into other nearby environmental zones. Inasmuch as the San Marcos Springs are at the lowest elevation of any of the Edwards-Trinity aquifer outputs, Takac realized these springs would have been the last water source to disappear during extremely dry periods. Taking into account the Clovis-aged drought postulated by Vance Haynes (1991), Clovis peoples would have been forced to rely on a smaller number of water sourcesthereby tying or tethering themselves to reliable water resources. Based on these ideas, Takac proposed a model in which some Clovis groups, previously highly mobile, began to restrict their movements to Central Texas and the Edwards Plateau because the still flowing springs at San Marcos and similar locations would have provided necessary refuge and an essential life resource during drought-stressed times (Takac 1992).

Unfortunately, Takac was never able to test this

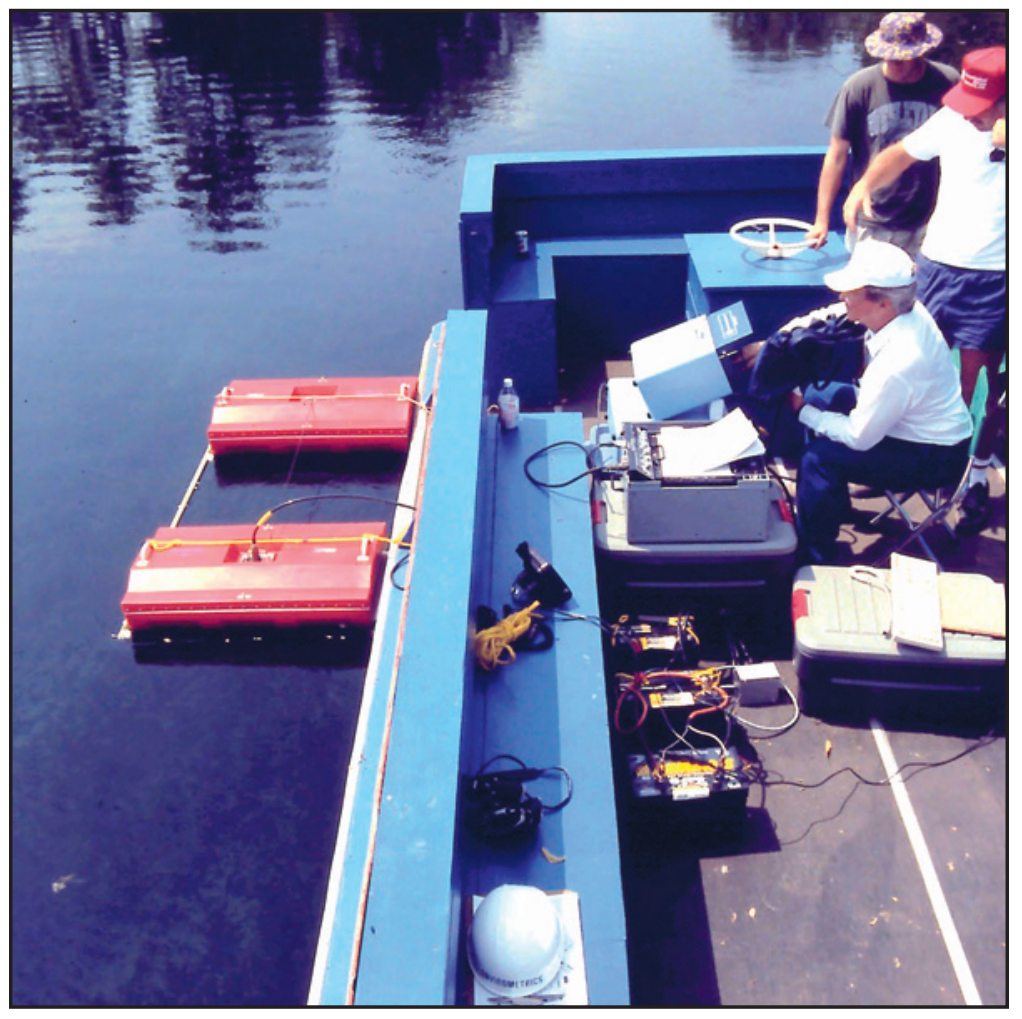

Figure 2-6. Ground-penetrating radar of the lake bed at Spring Lake, as being performed by Envirometrics. 
hypothesis. Although he planned a field season for the summer of 1992 to carry out further underwater excavation at the Terrace Locality, adequate funding was never secured, and the project was eventually abandoned.

\section{Spring LAKe Today}

Cumulatively, previous underwater work at Spring Lake has contributed significantly to the overall awareness of prehistoric occupation both regional and local, associated specifically with these freshwater springs. Both Shiner and Takac helped to advance underwater methodologies for collecting data, and their work, especially that of Shiner, drew archaeological attention to the site and its remarkable record. Many of the research questions addressed in their early work are still being considered by archaeologists today. New underwater geoarchaeological surveys are being conducted across the lake, some of which use remote sensing technology, such as sub-bottom profiling, to generate maps of sediment depths in some of the nowunderwater alluvial landforms. Archaeologists with the University and CAS are still working to resolve issues of chronology, site occupation, and subsistence. Considering the extent of deposits at Spring Lake and the fact that much of the record of the site's occupation is underwater, either under the lake itself or on ground but below the water table, this research will probably continue long into the future. 



\title{
Chapter 3 Projectile Points and Other Lithics
}

\author{
Harry J. Shafer and Thomas R. Hester
}

exas point typology and classification are among the best in the nation and continue to serve archaeologists well regarding questions and issues that stylistic classification addresses. An inherent problem occurs, however, in attempting to apply the conventional typology of Suhm et al. (1954), Turner and Hester (1999), and Turner et al. (2011) to the 41HY147 artifact assemblage: as discussed in Chapter 1, this collection was obtained from a context lacking stratigraphic integrity. The artifacts were recovered from the lake bottom in what, from our perspective, can only be described as secondary context.

The application of projectile point classification as Krieger (1944) intended it to be used requires that a type have meaning relative to space and time. In order to confidently assign a type designation to an artifact, archaeologists need solid contextual information about its chronological position. In the absence of such information (derived from the controlled excavation of a well-stratified site), the results of classification efforts become problematic. Point typology can provide chronological information if the correct types can be established. However, if no good chronological information is available, then the assignment of types may be questionable, especially in instances when stylistic overlap occurs among chronologically distinct types or when point type variants depart significantly from the norm. Some points, such as Montell or Folsom, can be easily typed inasmuch as they fit a commonly recognized conventional mold. However, the 41HY147 collection lacks the contextual precision that would aid in assigning confident type designations to certain other specimens. Examples of this problematic situation occur in the stylistic overlap between Uvalde and Gower variants as well as among variations within the Pedernales type, particularly when working with fragments. 
The authors have taken into consideration the lack of stratigraphic information in assigning type designations to the projectile points in this collection.

\section{Projectile Points}

The projectile points from excavations by Joel Shiner and Paul Takac at $41 \mathrm{HY} 147$ are described below. When we were confident about their classification, specimens have been sorted according to type. Descriptions of projectile point types are arranged alphabetically, beginning with dart points and followed by arrow points. Measurements of and descriptive information about the specimens selected for this analysis are presented in tabular form in Appendices A-D at the end of the report: Appendix A provides information about classifiable projectile points; Appendix B contains information about fragments of projectile point that lack defining characteristics; Appendix $\mathrm{C}$ lists information about preforms and biface fragments; and Appendix D contains information about other stone tools and artifacts. When applicable, notations are included about break types and evidence of reworked blades. Break types and reworked blades or tips provide information about the life history of the artifact, particularly if the break was caused by impact or manufacturing error. Stem width is measured because it may relate to the width of the foreshaft. These data may be useful to future research about foreshaft and stem technology.

\section{Dart Points}

\section{Abasolo-like $(n=2)$}

Two teardrop-shaped bifaces in the collection (Figure 3-1) resemble Abasolo, a point type common in the south Texas Coastal Plain, where it is regarded as a Middle Archaic type (Turner et al. 2011). Specimen No. 288-33 is complete, but the workmanship is rather crude. Specimen No. 112 lacks the tip and was broken by impact; the blade also had been reworked. Although Abasolo is common in Middle Archaic contexts throughout south Texas, it has not been securely dated in isolated components. Because $41 \mathrm{HY} 147$ is well beyond the expected geographic range of Abasolo, these two bifaces are grouped on the basis of form only.

\section{Andice ( $n=3)$}

Andice points (Figure 3-2) have very distinctive massive barbs and long stems with characteristic bifacial

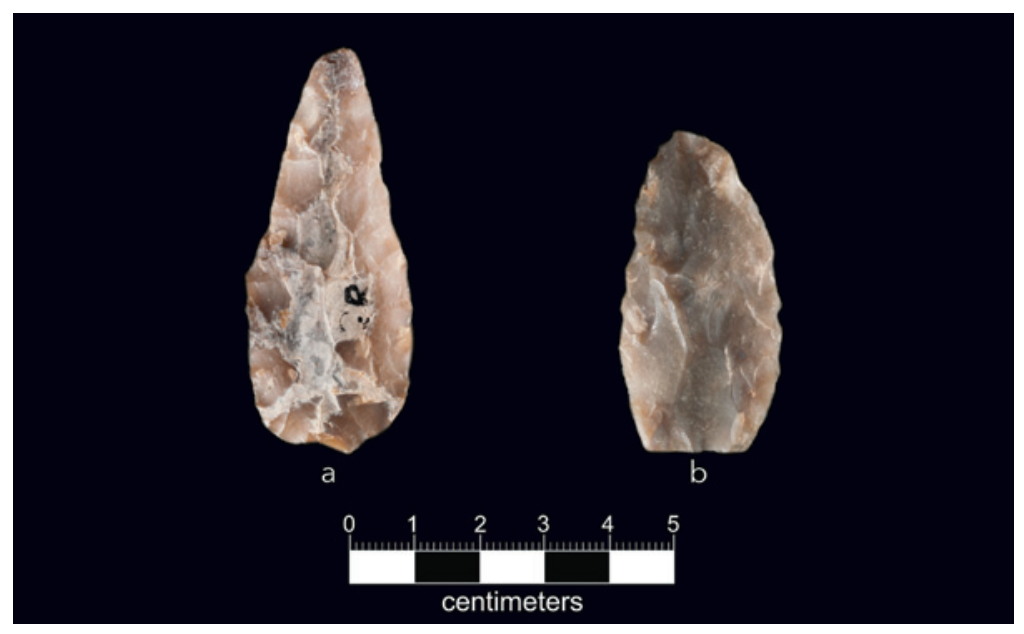

Figure 3-1. Abasolo-like points: (a) Specimen No. 288-33; (b) Specimen No. 112. 
workmanship along the edges. All three fragments in this collection are from the proximal ends, and one (Specimen No. 247-1) displays an impact fracture. This specimen consists of a stem with no barbs; the stem is relatively long and parallel with a straight base. Two fragments were broken by snap fracture, and one was burned. The base forms and technology, however, are characteristic of the type, particularly the unmistakable steep pressure flaking along the stem edges which aids in classifying even barb fragments. An excellent discussion of Andice technology is presented by Collins (1994).

Andice points are an Early Archaic diagnostic point type that often occurs in mixed components together with Bell and Early Triangular points (though not necessarily the same age as Early Triangular). The approximate date range for Andice is 6000-4000 B.P. (Collins 2004:120; Mahoney et al. 2003). This was a xeric interval during which time bison were present in the study area (Jon Lohse, personal communication 2011). Collins, together with Johnson and Goode (1994), suggest that the new broad, thin-blade technology characterizing these types was brought to the region by people from the prairies west of the Ozarks since Andice is the regional designation for Calf Creek, a type found west of the Ozarks (Wyckoff 1994a, 1994b).

\section{Angostura $(n=10)$}

Based on morphology and attributes of proximal end, ten points are classified as Angostura (Figure 3-3). Stems are slightly contracting, and stem edges are abraded to varying degrees. None is complete. One specimen (No. 288-28) has been refashioned from a point that had oblique-parallel flaking on the blade, perhaps a St. Mary's Hall point. Five specimens display clear impact fractures (e.g., 309-12), and the distal fracture on another (306-1) may also be due to impact. The most common fracture type is snap/bending where the blade has been subjected to a bending stress that exceeded the elastic limits of the chert. Many of these snap breaks

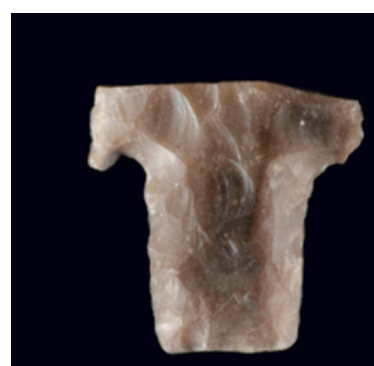

a

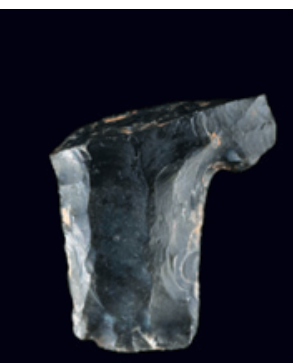

b

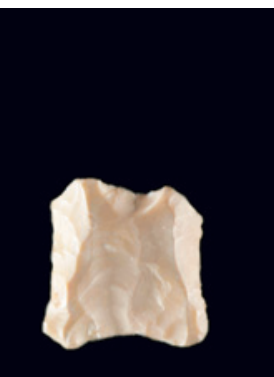

C

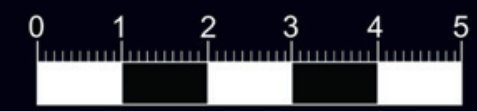

centimeters

Figure 3-2. Andice points: (a) Specimen No. 99-1; (b) Specimen No 247-1; (c) Specimen No. 49-1.

were probably caused by impact.

Angostura points are widespread throughout Central Texas, especially along the Balcones Escarpment, and in the prairies and coastal plain to the south, east, and southeast (Prewitt 1995:90). Chronologically, this point type bridges the sequence from Late Paleoindian to Early Archaic. Recent 
radiocarbon dates from the Richard Beene site in Bexar County yielded good context for dating Angostura points (Thoms and Clabaugh 2011). Conventional radiocarbon dates for this component are $8640 \pm 60$ B.P. and $8805 \pm 75$ B.P.

\section{Angostura Preform $(n=2)$}

Two bifaces are classified as possible Angostura preforms. Specimen No. 238-1 is a proximal fragment with an unfinished base and a moderately contracting stem. Specimen No. $42-1$ is complete and, although it appears to be unfinished, has the overall form of Angostura. Specimen No. 238-1 has slight grinding along the base edges. It was broken by a snap fracture, perhaps during

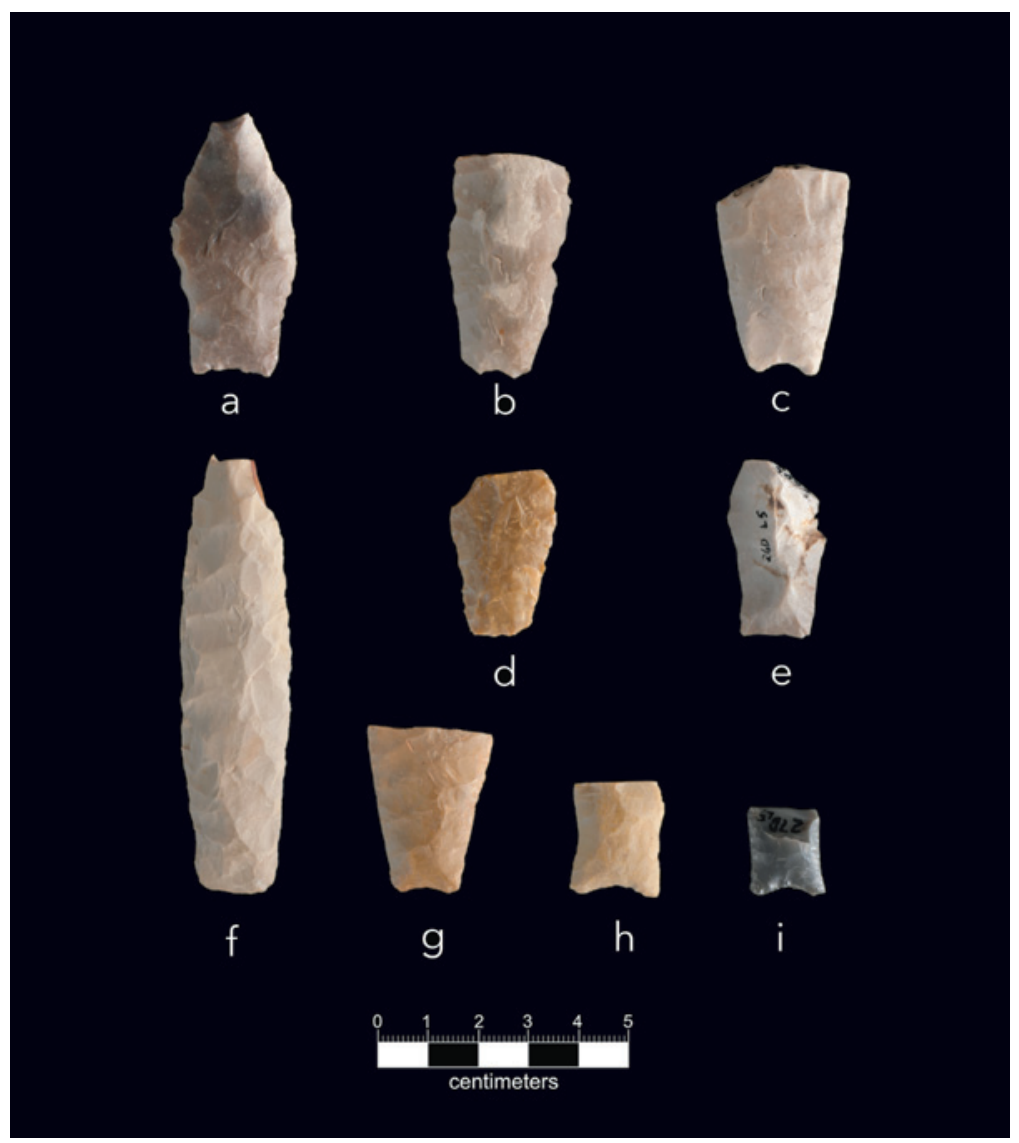

Figure 3-3. Angostura points: (a) Specimen No. 303-1; (b) Specimen No. 108-1; (c) Specimen No. 81-3; (d) Specimen No. 55-1; (e) Specimen No. 23-5; (f) Specimen No. 109-1; (g) Specimen No. 309-12; (h) Specimen 306-1; (i) Specimen No. 27-1. manufacture.

\section{Bandy $(n=3)$}

This Early Archaic point type is characteristically very thin, has an expanding stem with a fishtail-like base, and is barbed. All three Bandy specimens in the collection (Figure 3-4) fit this description precisely. Two (Specimens No. 56-1 and No. 261-1) exhibit evidence of direct impact fractures, and one (Specimen No. 56-1) also has a rejuvenated blade.

Bandy points, first described by James Word (Word and Douglas 1970:21) and named after his friend Charles Bandy, who helped to excavate Baker Cave, have been found to be a horizon marker for the Early Archaic across the Balcones Canyonlands from Comal County to Val Verde County (Texas Beyond History, 2011b; Houk et al. 2008:Appendix E; Quigg et al. 2008:429-432). These early points date to approximately 6000-5000 B.P. according to dated components at Skyline Shelter (Turpin and Bement 1992) and the Varga site (Quigg et al. 2008:460). 
Base- and Side-Notched $(n=1)$

Specimen No. 16-1 (Figure 3-5) does not fit any conventional description but is listed here

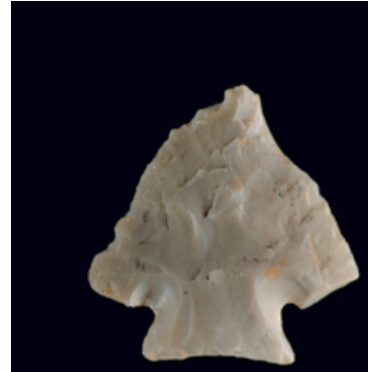

a

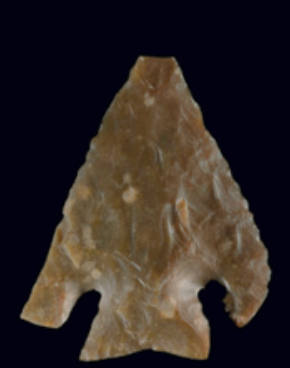

b

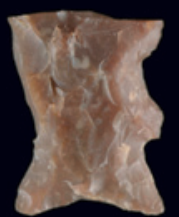

C

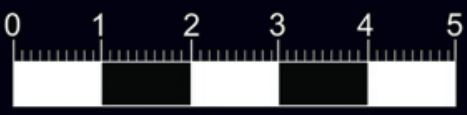

centimeters

Figure 3-4. Bandy points: (a) Specimen No. 56-1; (b) Specimen No. 179-2; (c) Specimen No. 261-1.

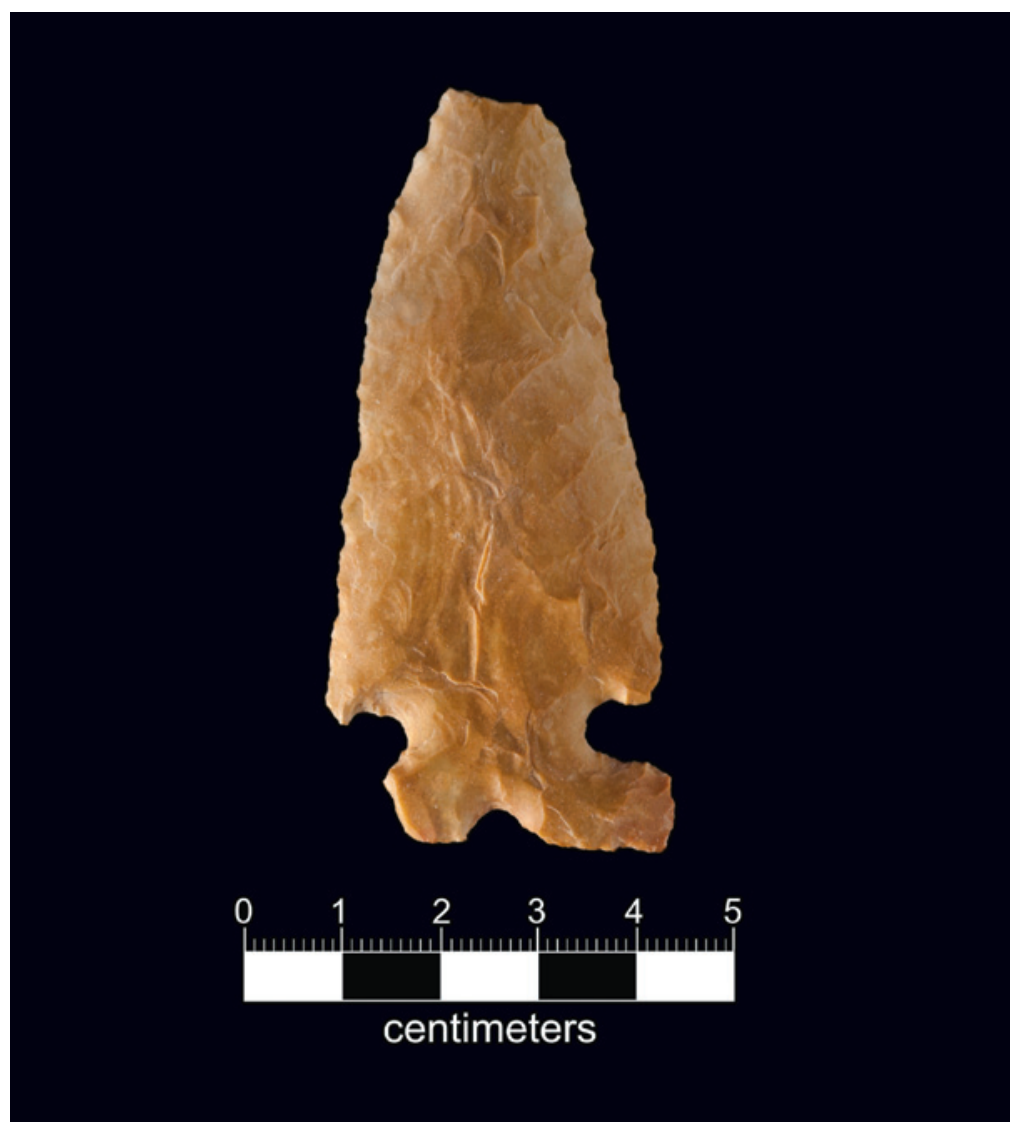

Figure 3-5. Base- and side-notched point, Specimen No. 16-1. because of its unique

characteristics. It is a large, broad, side-notched point with a thin blade. The uncharacteristic attribute is a deep $\mathrm{V}$ notch in the base. Its hue is orange-yellow, and it does not appear to be made from local Edwards chert. The tip is missing.

The side notches could be regarded as a variant of Big Sandy, but the base notch and thin blade rather than the characteristic lenticular cross-section of Big Sandy precludes placing it into that type.

\section{Bell $(n=1)$}

Specimen No. 133-1 (see Figure 4-28, page 70) has a slightly expanding stem, a slightly indented base, and one surviving prominent barb. The tip was broken by an impact fracture, and the stem exhibits steep bifacial flaking used to create the long stem and prominent barb characteristic of Bell/ Andice point manufacture (Collins 1994). Bell points were first defined at the Landslide site in Stillhouse Hollow Reservoir (Sorrow et al. 1967:12) and consistently 
occur elsewhere in association with the culturally related, heavy-barbed Andice (Mahoney et al. 2003). The single specimen from $41 \mathrm{HY} 147$ conforms well to the description of the type (e.g., Turner et al. 2011:65).

Bell points date approximately to 6000-4000 B.P. (Collins 2004:120; Mahoney et al. 2003); a tight range of calibrated radiocarbon dates were obtained from the mixed Bell/Early Triangular component at the Royal Coachman site (41CM111) bracketed between 5780 and 5460 B.P. (calibrated at one sigma [Mahoney et al. 2003:61]). At the Cibolo Crossing sites, radiocarbon dates between 5300 B.P. and 4800 B.P. are linked to Bell (Kibler and Scott 2000). Wyckoff (1994a) considers Bell as part of the Andice/Bell/Calf Creek horizon extending from the Edwards Plateau and Coastal Plain of Texas northward into southern Kansas.

\section{$\operatorname{Big} \operatorname{Sandy}(n=1)$}

One artifact is classified as Big Sandy (Figure 3-6). Specimen 288-24 is a side-notched point with a straight base, shallow side notches, and a triangular blade. One ear is missing. The banded brown-black chert does not appears not to be of local origin.

Big Sandy points are rare in Central Texas but occur more commonly in east Texas and into the Southeastern United States (Turner et al. 2011:66). Recent radiocarbon dates on a Big Sandy component in Arkansas yielded a calibrated date of 5980 B.C. (Trubitt 2009).

A large side-notched dart point classified as Big Sandylike is reported by Gerstle et al. (1978:Figure 15. 1) from Camp Bullis in northern Bexar County; a somewhat similar specimen, though much more narrow, was classified as Big Sandy at the Gatlin site in Kerr County (Houk et al. 2008:Figure 1, Appendix C). Collins (1998:397) illustrates a Big Sandy base from WilsonLeonard. At the Sandbur site in Fayette County, a complete

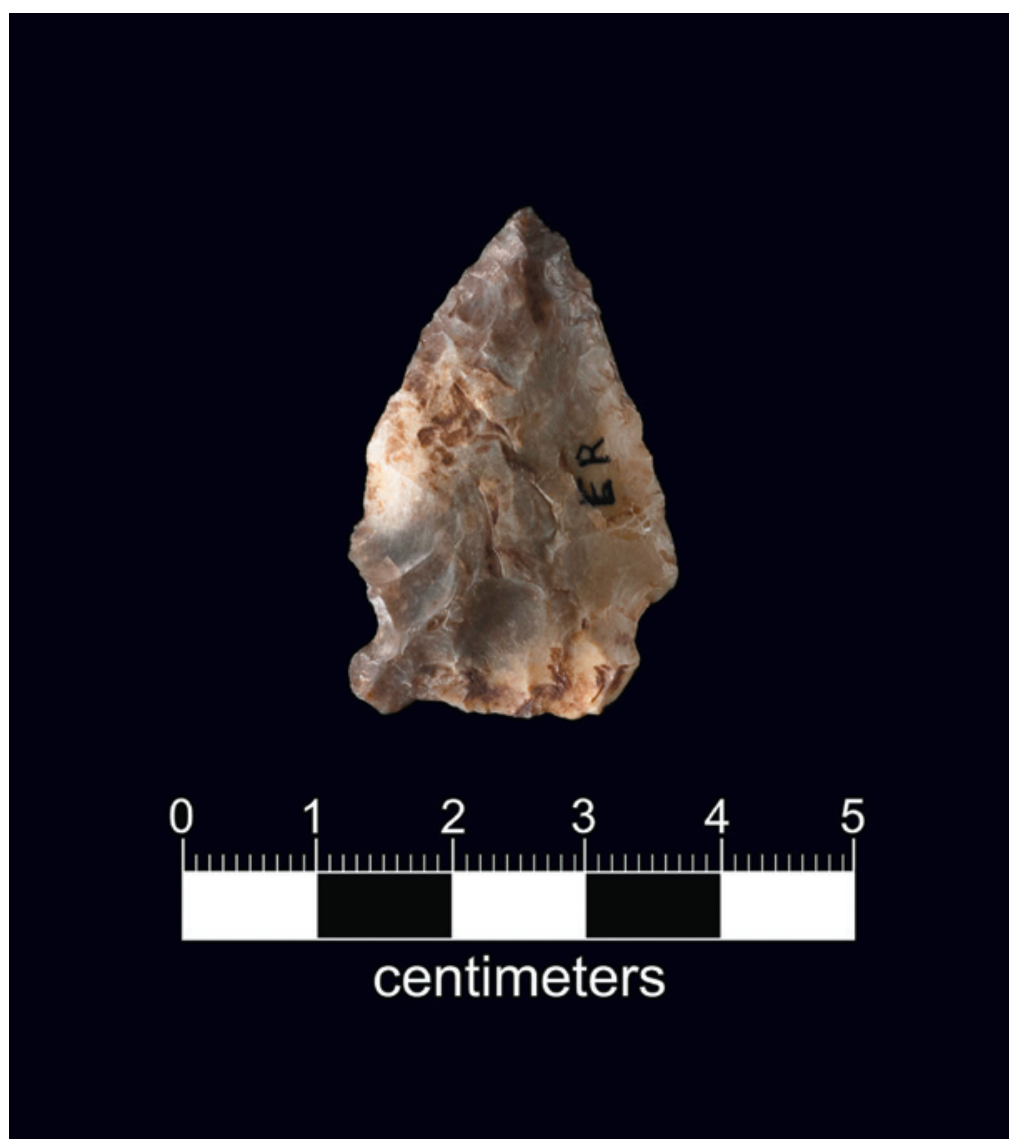

Figure 3-6. Big Sandy point, Specimen No. 288-24. 


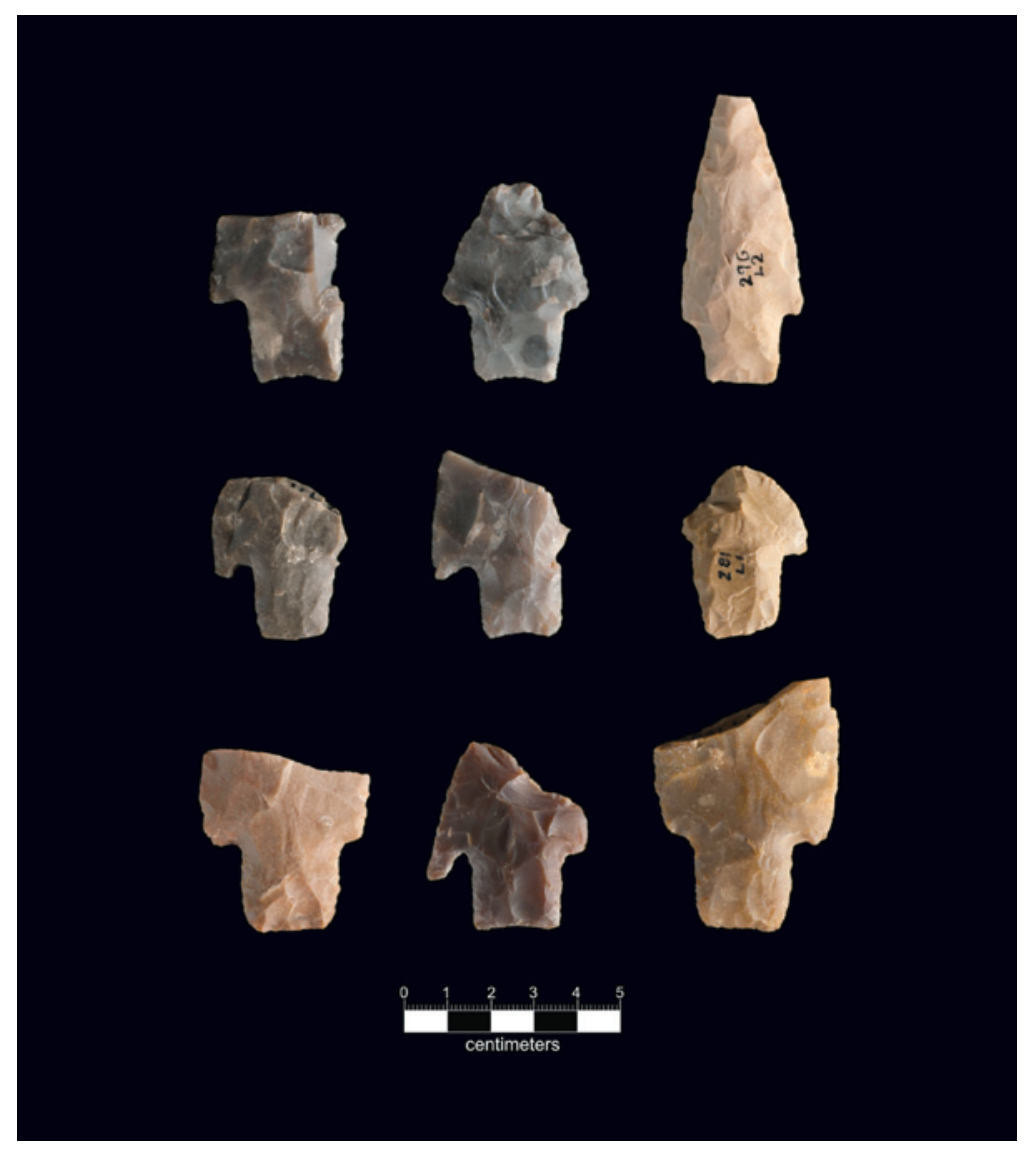

Figure 3-7. Bulverde points.
Big Sandy was found (Kalter et al. 2005:Figure 5-48). See Turner et al. 2011:66 for other Texas sites with Big Sandy points.

\section{Bulverde $(n=16)$}

These specimens (Figure 3-7) all display the classic form of Bulverde as originally described by Suhm et al. (1954:404). All but one are typical examples of Bulverde: the base profile tapers to a wedge-shaped base edge, stems are straight to slightly convex, and the shoulders are lightly barbed. The one variant (Specimen No. 1361) has a bulbar stem but otherwise has the overall characteristics of the type. Because the sample consists entirely of basal fragments with distal tips missing, blades on all are incomplete. Eleven show evidence of direct impact fractures. Seven exhibit snap breaks, including two with both direct impact and snap break. Three have reworked blades indicating in-field repair while the point was being hafted.

Bulverde points are an early Late Archaic marker for the eastern Edwards Plateau area, especially in the region from San Antonio to Georgetown. The temporal span for this type is approximately 4000-3500 B.P. (Collins 1998:Figure 4-1), and Bulverde precedes Pedernales in Central Texas chronology (Collins 1998:Figure 4-1; Sorrow et al. 1967:Figure 72).

\section{Castroville $(n=13)$}

The Castroville type (Figure 3-8) is characterized by broad, slightly expanding stems and broad, thin blades with prominent barbs (Turner et al. 2011:71-72). Three specimens are complete, but two of these have reworked blades. Six show evidence of impact fractures on blades; two have snap fractures. All are well made and conform to the thin, broad blade style characteristic of the type. 
Castroville points are a dominant type across much of the Edwards Plateau and adjacent parts of the Gulf Coastal Plain. The approximate date range for Castroville points is 400-800 years B.C. (Turner et al. 2011:71, 72). Calibrated radiocarbon dates from Bone Bed 3 at Bonfire Shelter, the Castroville/Montell component, yielded four dates that averaged 2645 B.P. (Turner et al. 2011:71).

\section{Clovis $(n=3)^{*}$}

One of two classic Clovis points in the collection (Figure 3-9), Specimen No. 310-1, has a much reworked blade, although it displays the characteristic attributes of the type: lenticular cross

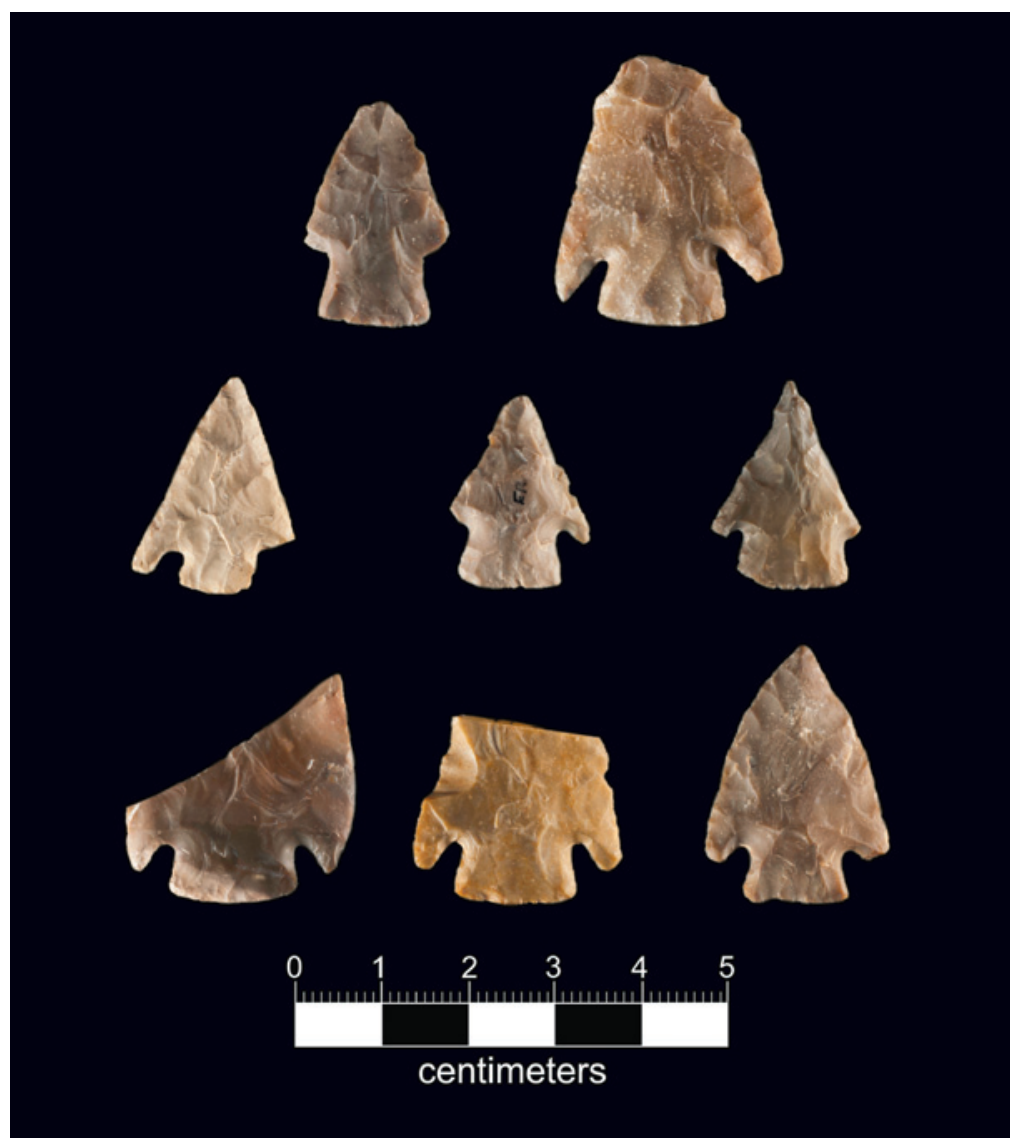

Figure 3-8. Castroville points. section and fluted base on both sides. The tip has been damaged. The base is thinned by a single flute on each face. Provenience information is not available.

The second Clovis point (Specimen No. 310-2) is much longer, but has been subjected to postdepositional damage. The chert is stained from a long period of submersion. This point has a single flute on one face and two parallel flutes on the opposite face. Provenience information is not available.

Specimen No. 77-2 is the base of a Clovis point fluted on one face; the opposite face shows a flat surface created by overshot thinning, which is commonly seen on Clovis points. The basal edges are slightly ground. The reddish brown chert does not appear to be of local origin.

\footnotetext{
* Two Clovis points, Specimen Nos. 310-1 and 310-2, and several other artifacts comprising Lot 310 were not recovered from $41 \mathrm{HY} 147$, but rather were apparently collected by screening sediment that was originally part of site $41 \mathrm{HY} 160$, located just across the early stream channel before the springs were dammed. These sediments were removed by a dredge and deposited into the mouth of Sink Creek where it joins Spring Lake today. While they were workig at 41HY147, Shiner and his students screened some of this material that had originated from 41HY160 and recovered at least one Clovis point (Specimen No. 310-2) as well as Golondrina, Marcos, Scallorn and Perdiz points (see discussion in Chapter 2). As is the case with the collection from the Terrace Locality, none of the material from $41 \mathrm{HY} 160$ has ever been reported. It is included in this analysis because it is attributed to Shiner's work in the lake and because it is important in filling out the picture of prehistoric occupation at Spring Lake.
} 


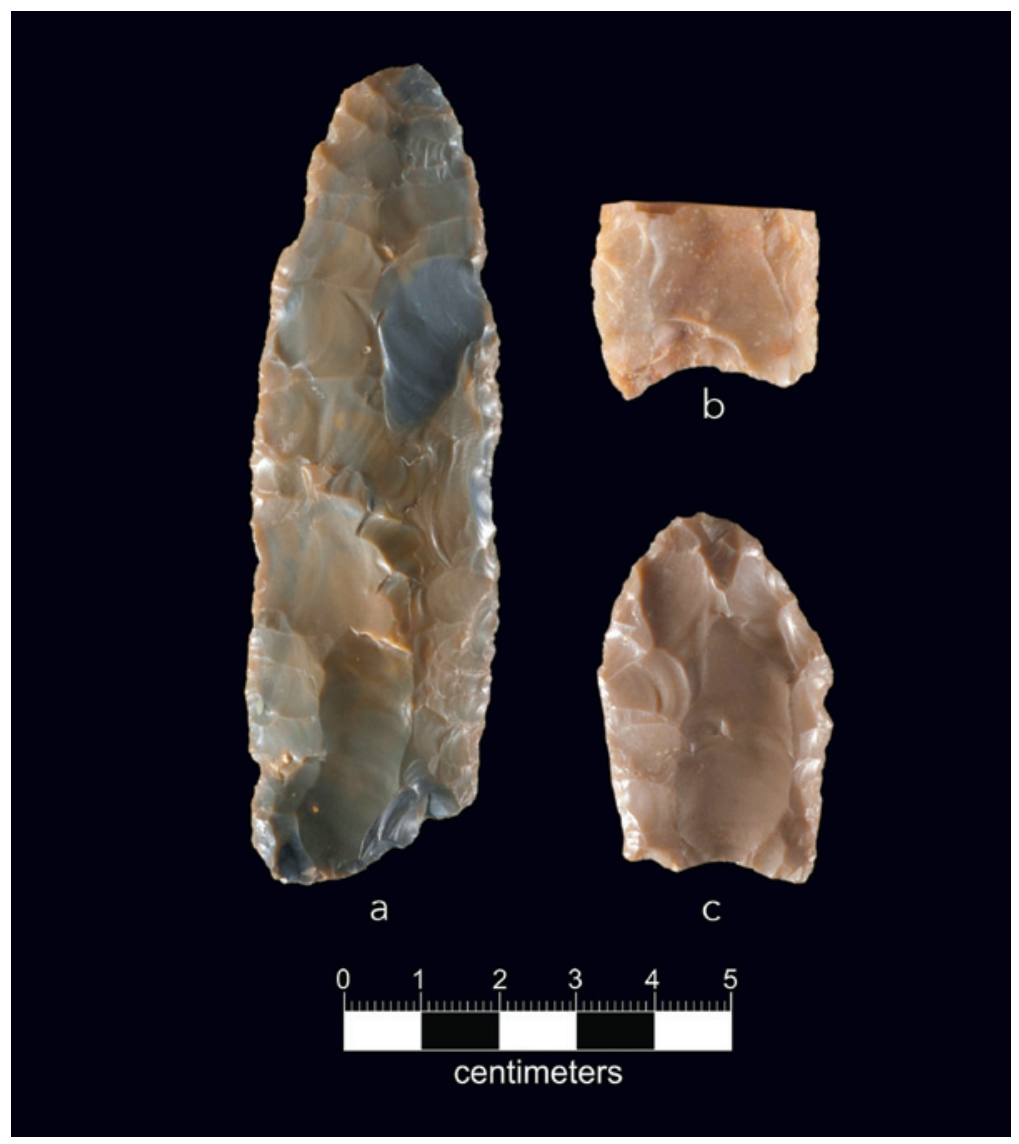

Figure 3-9. Clovis points from Spring Lake: (a) Specimen No. 310-2; (b) Specimen No. 77-2; (c) Specimen No. 310-1.

A fourth Clovis point from the site, a large specimen published by Shiner (1983:Figure 1) was not available for analysis.

The radiocarbon dates for the Clovis era in North America, generally dated to 11,500-10,900 B.P., have recently been reevaluated by Waters and Stafford (2007), who now date Clovis to $11,050-10,800$ B.P. (uncalibrated radiocarbon years). The oldest date, however, does not include the two dates from the Aubrey site (Ferring 2001), which Waters refuted.

\section{Possible Clovis Base $(n=1)$}

Specimen No. 13-1 (Figure $3-10)$ is the very base of a fluted point with a lightly ground base. One face is fluted and the opposite face is basally thinned. One edge has been damaged by postdepositional alteration, possibly by a trowel since the damage is unifacial.

\section{$\operatorname{Darl}(n=1)$}

Specimen No. 80-1 is the proximal fragment of a small Darl point (Figure 3-11) with a parallelsided stem, slightly indented base, and slight shoulders. It was made with fine pressure flaking but was badly damaged by burning.

Darl points were first named by Miller and Jelks (1952) based on the preliminary work at Belton Reservoir in Coryell and Bell counties. The type is a dominant terminal Archaic form between the Brazos and Colorado Rivers along the Balcones Escarpment and prairies to the east, but becomes only a minor type south of the Colorado River (see Prewitt 1995:Figure 14). Secure dates for Darl have been elusive, although the J. B. White site in Milam County yielded a calibrated probable date of A.D. 650. Stratigraphically, Darl precedes Scallorn throughout much of Central Texas south and west of the Brazos River. 


\section{Early Barbed $(n=1)$}

Specimen No. 59-1 is a point with a slightly contracting stem, indented base, and broad blade with small barbs(Figure 3-12). The blade has been reworked and is patinated on one face. The type designation is based on similar Early Barbed specimens in the Lower Pecos region (Parsons 1965:Figure 7i; Prewitt 1966; Ross 1965:Figure 12g-1). Early Barbed points occur in the same general analysis units and association with Gower, Uvalde, and Laguna points, ca. 6000-5000 B.P., based on the Devils Rockshelter assemblage (Prewitt 1966).

\section{Early Triangular $(n=17)$}

As the name of these points suggests, their shape is triangular. Early Triangular points are marked by very careful flaking, often paralleloblique along the lateral edges. Bases are often slightly concave and thinned. Blades are characteristically slightly beveled along one edge, right or left. At least five of these specimens (Figure 3-13) exhibit direct impact factures, and four show snap fractures, probably from impact, indicating they were used as

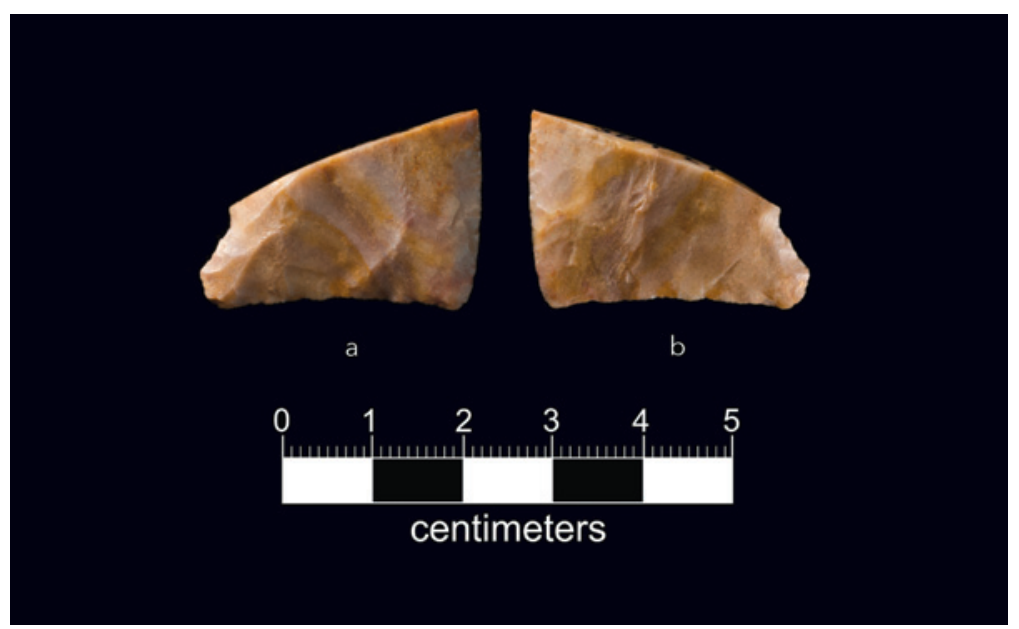

Figure 3-10. Possible Clovis base, Specimen No. 13-1: (a) fluted face: (b) basally thinned face.

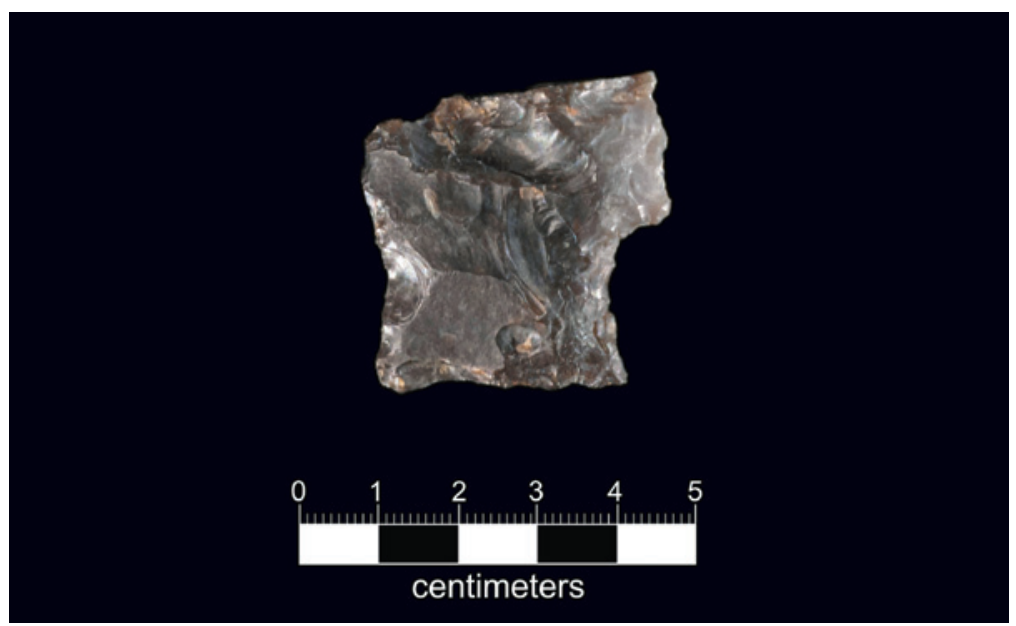

Figure 3-11. Proximal fragment of a Darl point, Specimen No. 80-1.

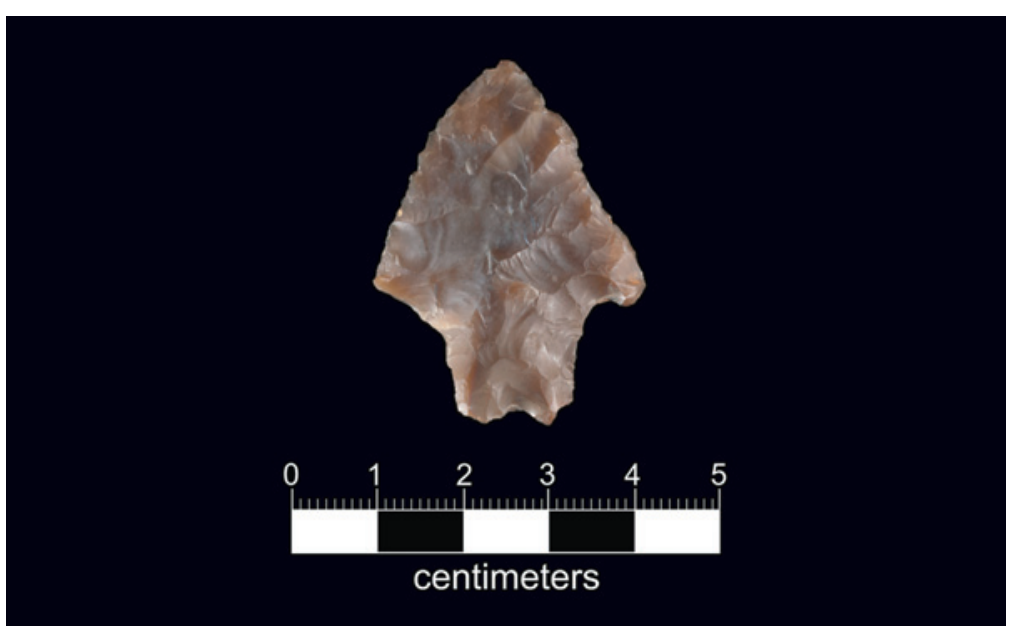

Figure 3-12. Early Barbed point type, Specimen No. 59-1. 


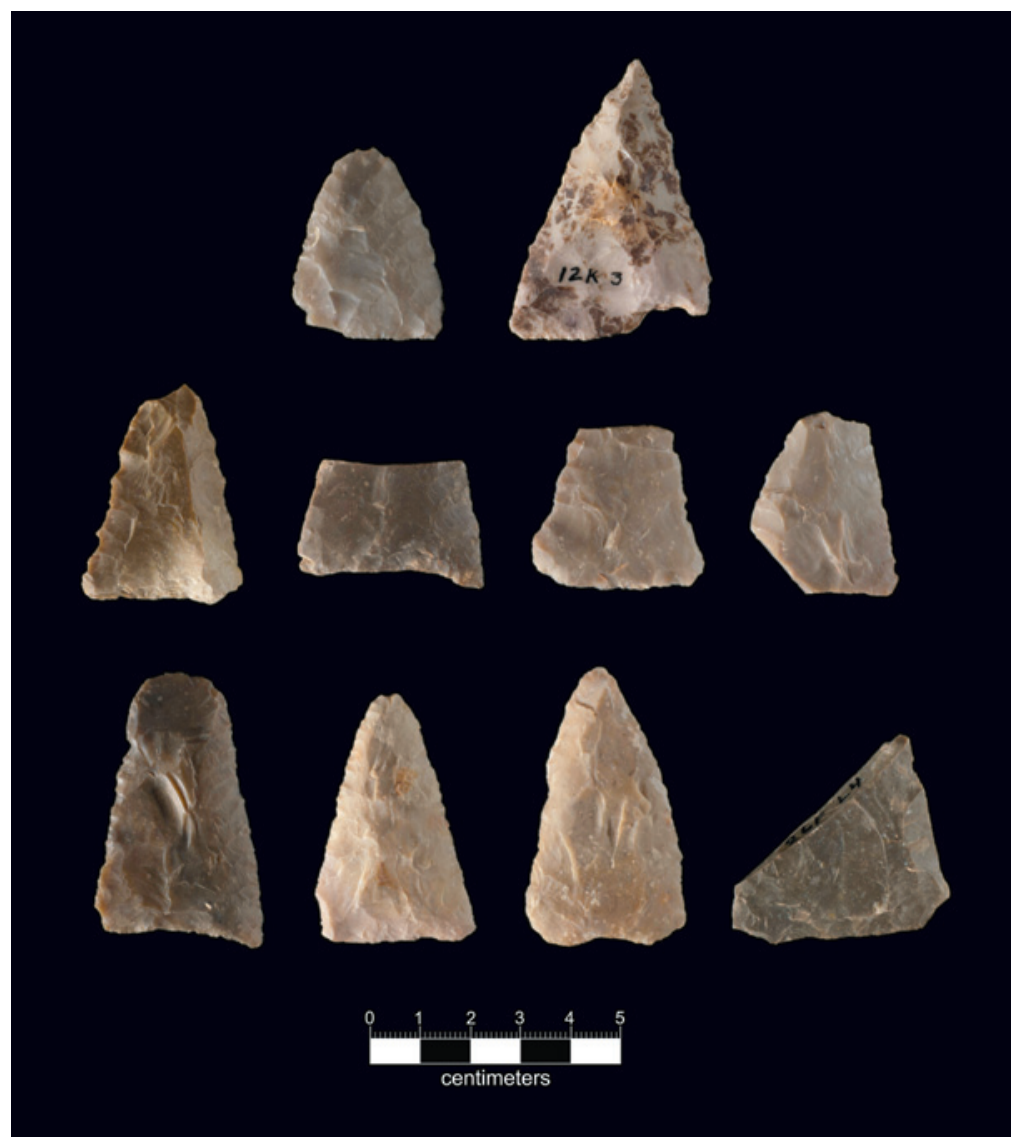

Figure 3-13. Early Triangular points. projectile points (see work by Harry Iceland about Early Triangular microwear, in Decker et al. 2000:256-263).

Early Triangular points have been variously called Baird Beveled Blade or Taylor Thinned Base. The type occurs in early Middle Archaic components in the Edwards Plateau. One of the largest samples of Early Triangular points was recovered from occupation zone 3 at the Gatlin site in Kerr County (see also report on Woodrow Heard site [Decker et al. 2000]), but this deposit was a badly mixed zone that yielded a range of other point types including Gower, Martindale, Bandy, Andice, Bell, Langtry, Montell and La Jita. Radiocarbon

dates from Nueces County range from 5919 B.P. to 4862 B.P. (Turner et al. 2011:58), more in line with Turpin and Bement (1992:52), who report a date of 5920 B.P. from the Lower Pecos.

A number of archaeological studies from the Edwards Plateau link the Early Triangular form with Martindale and Uvalde points (Black and McGraw 1985; Houk et al. 2008; Decker et al. 2000; Karbula 2000). Excavations at 41ME147 uncovered an Early Triangular component, without any other associated types, in a stratum below La Jita, and an overlying one with Nolan (Hester 2011:3). Though no radiocarbon dates are yet available for this sequence, a La Jita component is linked to a date of 4260 B.P. at site 41BN63 (Dornheim 2002).

\section{$\operatorname{Ensor}(n=8)$}

Ensor points (Figure 3-14) are made on triangular preforms and are corner notched with triangular blades. Two Ensor specimens exhibit direct impact fractures, three have snap fractures, one exhibits both direct impact and snap, and two are burned. Ensor points consistently date ca. 2100-1200 B.P. (Turner et al. 2011:94). 


\section{Chapter 3}

This sample of Ensor points contains two varieties that have their own general geographic distribution. One is a narrow form with distinctive deeper corner notches with straight or slightly convex bases; the other variant has a widebase form with shallower notching (see Turner et al. 2011:95, 96). The geographic distribution of the narrow form is mostly from San Antonio northward to the Brazos River along the Balcones Escarpment, while the wider base and shallow notch form trends from San Antonio/San Marcos to the Lower Pecos River Canyonlands.

\section{Evant $(n=10)$}

Evant points (Figure 3-15) are a newly defined type

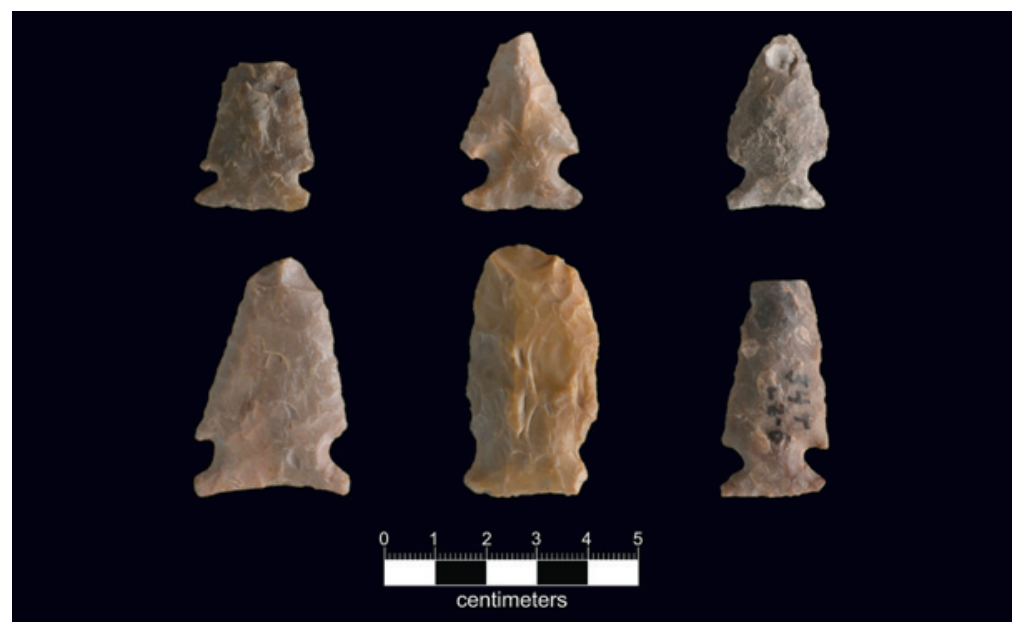

Figure 3-14. Ensor points.

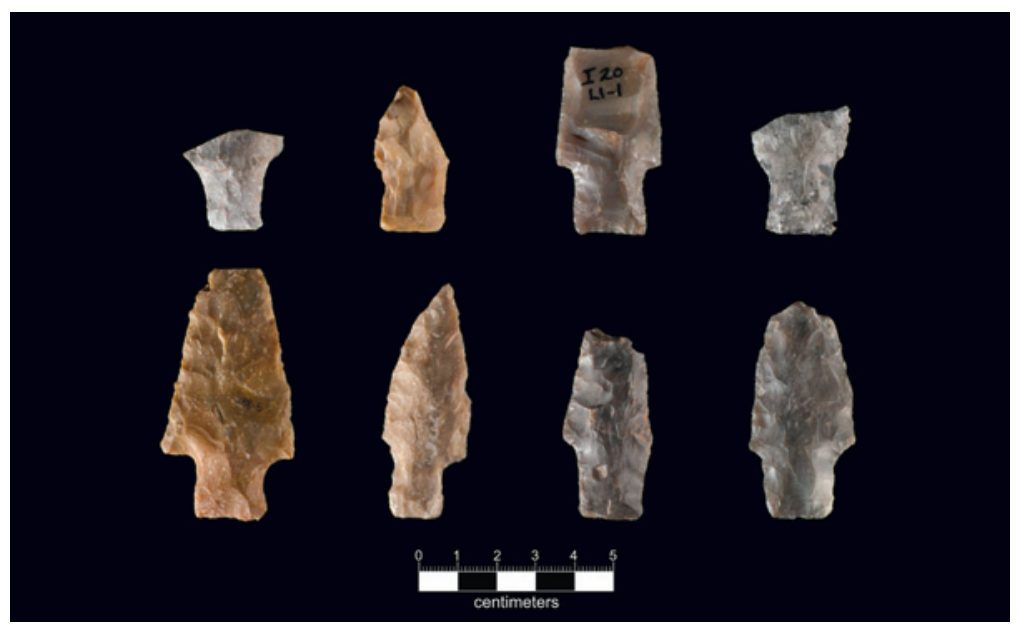

Figure 3-15. Evant points.

(Turner et al. 2011:95-96)

characterized by rectangular stems, moderate shoulders, and triangular blades, some of which have slightly convex blade edges. Only two of the Evant specimens in this collection are complete; four exhibit direct impact breaks, one has both an impact and a snap break, two are burned, and one has a reworked blade.

Evant points are similar to Bulverde except for the wedge-shaped stem of the latter. The type occurs in the same stratigraphic position as Bulverde, below Pedernales, along the Lampasas, Leon, and San Gabriel Rivers and their tributaries in Bell, Coryell, Hamilton, and Williamson Counties. The type is also similar to Travis, but lacks the square stem of the latter. It is a prominent Middle Archaic type at Fort Hood. Abbott and Trierweiler (1995), for example, classified Evant points as Bulverde, and Trierweiler (1996) called them Kent. Schuetz (1957) illustrates certain specimens that she classified as San Gabriel points that fit the description of Evant points from Williamson County. They also occur in Bell County along 


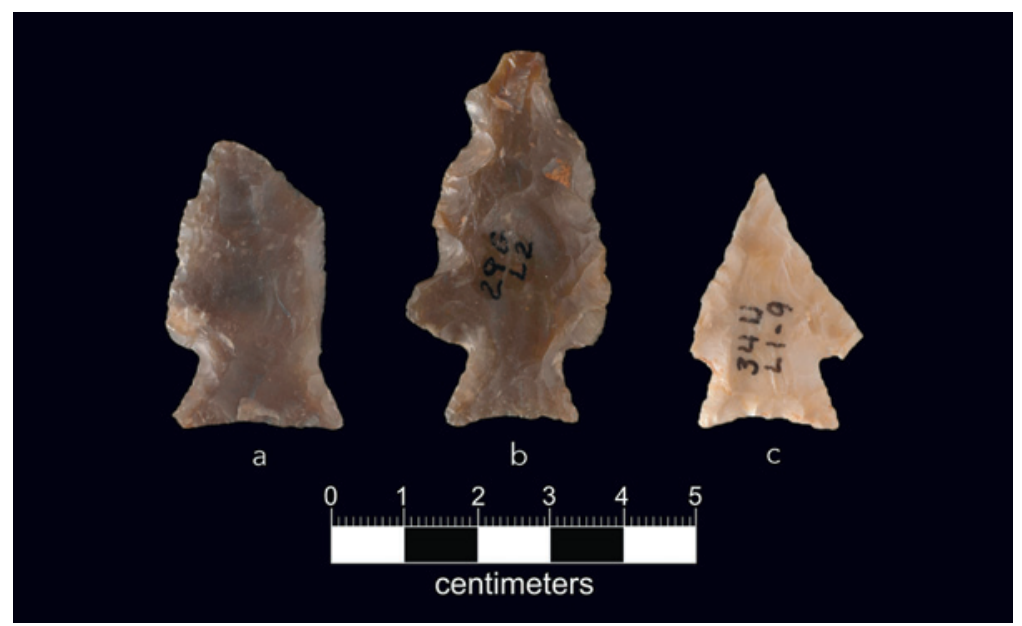

Figure 3-16. Fairland points: (a) Specimen No. 24-3; (b) Specimen No. 29-3; (c) Specimen No. 299-1. the Lampasas River (Shafer 1963; Sorrow et al. 1967).

Fairland $(n=3)$

Fairland points (Figure 3-16) are thin, delicately fashioned points with expanding stems, slightly indented bases, barbed shoulders, and thin blades. Two specimens were broken by direct impact fractures and the third is a complete specimen with a reworked blade.

Fairland points occur late in the Late Archaic sequence, coeval with Darl; we estimate the approximate date range for Fairland to be 1500-1200 B.P. based on their occurrence at the end of the Archaic sequence just prior to the introduction of the bow and arrow, which is dated ca. 1100 B.P. or ca. A.D. 800 (date estimates are provided by Collins 1998:Figure 4-1). Precise dates on components yielding Fairland are not yet available. The geographic distribution of the type seems to trend south of that for Darl, along the front edge of the Edwards Plateau (see Prewitt 1995:100, 104).

\section{Folsom $(n=1)$}

Specimen No. 119-2 is the distal portion of a classic Folsom point with characteristic channel flutes and delicately flaked, slightly convex lateral edges (see Figure 4-5, page 62). The flutes extend nearly the entire length on one face but terminate near the tip on the opposite face. It is made from creamy-pink, mottled Edwards chert, which is nonlocal to the area.

Folsom points are well dated throughout the Southern High Plains, with dates clustering around 10,500 B.P. \pm 300 years (Meltzer et al. 2002). Turner et al. (2011) mention several central Texas sites with Folsom points, such as Kincaid Rockshelter and Pavo Real (41BX52). Bone Bed II at Bonfire Shelter also yielded a Folsom point (Dibble and Lorrain 1968:36).

\section{Possible Folsom Base $(n=1)$}

This specimen is a burned fragment of a base with one fluted face apparent, although it is so badly damaged that the opposite face is missing (see Figure 4-6, page 62). The base is concave but there is no trace of a striking platform nipple typically seen on classic Folsom points. The lateral edges exhibit the delicate bifacial pressure flaking that, together with fluting, is a defining characteristic of the type. 


\section{Chapter 3}

\section{Frio $(n=3)$}

Frio points (Figure 3-17) are Late Archaic diagnostics often occurring in the same components with Ensor in the Balcones Canyonlands (see Prewitt 1995:106; Turner et al. 2011:106). Variations in the width of the base and blade are geographically similar to that of Ensor points. Narrower versions occur in the northern part of the Balcones Escarpment (see Miller and Jelks 1952:Pl. 22[2]), while wider versions tend to occur in the Canyonlands from Bexar County westward to the Lower Pecos (see variations in Turner et al. 2011:106). The accepted date range for Frio is 200 B.C. to A.D. 600.

Specimen No. 245-2 is a classic Frio with the typical corner-notched stem and notched base. The other examples are badly damaged but also bear characteristics of the type. Specimen No. 102-3 was split by impact and the other was badly burned.

\section{Golondrina $(n=3)$}

The Golondrina point type (Figure 3-18) is characterized by deeply indented bases, basal edges that are slightly concave, ground, and flared at the basal tip. Blades are usually lanceolate with slightly convex edges. Specimen No. 91-2, however, has a much-reworked blade beveled along the right and a distal impact fracture. Specimen No. 310-7 likewise exhibits a distal impact, as does No. 309-13, which also has a snapped blade.

Golondrina points were first described by Johnson (1964) at the Devil's Mouth site and have subsequently been found to be a relatively common type in Late Paleoindian components in 


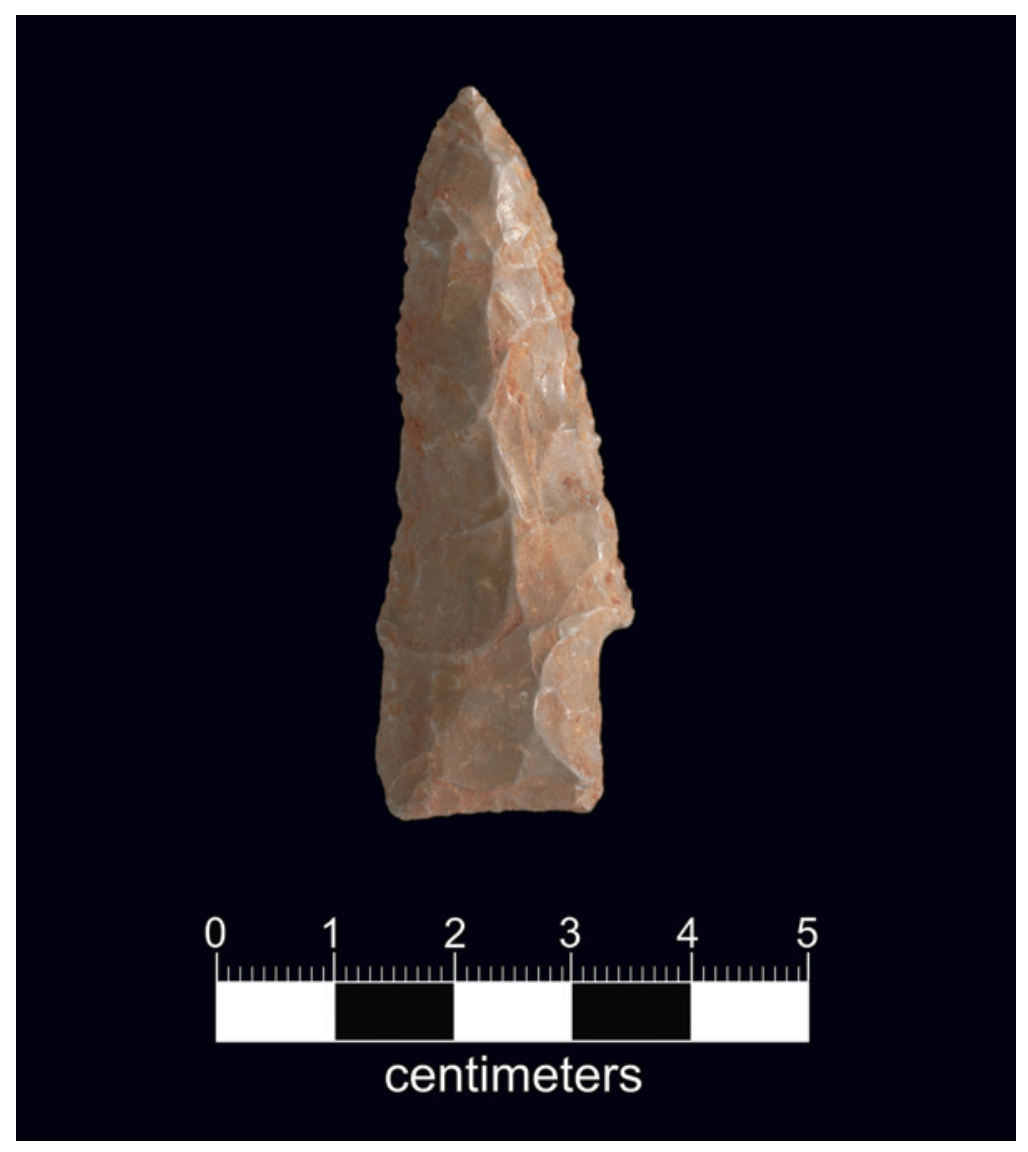

Figure 3-19. Hoxie point, Specimen No. 32-1.

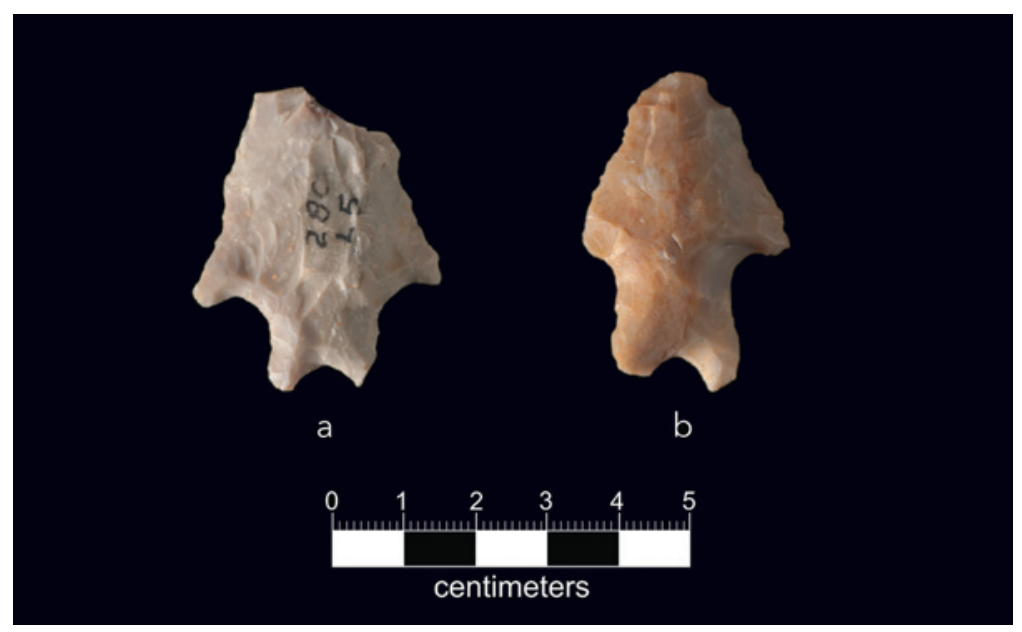

Figure 3-20. Jetta points: (a) Specimen No. 29-5; (b) Specimen No. 288-1. the Edwards Plateau, along the Balcones Escarpment, the Texas Coastal Plain, south Texas, and into Nuevo Leon (Epstein 1969; Turner et al. 2011:110, 111). Radiocarbon dates for Golondrina obtained from Baker Cave range from 7080 to 6830 B.C. (Hester 1983:104).

\section{Hoxie $(n=1)$}

Specimen No. $32-1$ is a long, narrow point (Figure 3-19) with a parallel stem, indented base, one weak shoulder and one shoulder removed by reworking the blade. Because of the repair, the blade is asymmetrical but nevertheless displays alternate beveling along the right edge. It resembles a Darl point in many ways but is thicker, with ground edges of the base and stem.

Hoxie points are an Early Archaic type (Collins 1998:352), although components containing Hoxie have not been accurately radiocarbon dated.

\section{$\operatorname{Jetta}(n=3)$}

Jetta points (Figure 3-20) are characterized by deeply indented bases, parallel stem edges, slight barbs, and triangular blades that twist to the left (Specimen No. 39-5) or right (Specimen No. 288-1). The latter specimen is broken by a direct impact fracture. 


\section{Chapter 3}

Jetta points appear to be in the genre of Gower/Uvalde and are often grouped with those two types. The Gatlin site yielded a series of dates on the Gower component; these were: 5320-5050 B.P., 7150-7130 B.P., and 7020-7420 B.P. (Smith and Oksanen 2008:Table 7.2). The approximate estimated Early Archaic date based on co-occurrence with Gower/Uvalde is 6000-7500 B.P.

Jetta points were first recognized at the Jetta Court site in Austin (Wesolowsky et al. 1976), though similar points were earlier shown to co-occur with Gower at the Youngsport site (Shafer 1963:Figure 7i). Crawford (1965:Figure 3h-l) illustrates several specimens from the Granite Beach site at Lake Buchannan that would be classified as Jetta. Twelve examples were recovered from the Wilson-Leonard site in various stratigraphic locations (Dial et al. 1998:355-357). The whole issue of Uvalde/Gower/Jetta is unresolved, both typologically and in terms of dating.

\section{Laguna $(n=2)$}

Laguna is a newly defined type (Turner et al. 2011:124, 125; Weber 2009). These points are distinguished by their wide, outswept, square-tipped barbs, weakly convex stem edges, and slightly concave bases (Figure 3-21). Base concavity varies from 2 to $3 \mathrm{~mm}$. Barb tips on both specimens are broken, but the stem and blade morphology are consistent with the type. Blades are extremely well made, and one (Specimen No. 159-2) exhibits oblique-parallel pressure flaking. Blade edges on both are slightly concave.

Laguna points have previously been classified as variants of Early Barbed (Prewitt 1966:Figure 4f, 4g) and Bell (Decker et al. 2000). Specimens from the Gatlin site were classified as Early Barbed Devil's Variant (Houk et al. 2008:17). Stratigraphically they are thought to predate Bell and Andice, at roughly 6900 B.P., based on radiocarbon dates from the Richard Beene site (Weber 2009). They are a recurrent type along the Balcones Escarpment to the Lower Pecos region.

\section{Lange $(n=9)$}

As a group Lange points (Figure 3-22) have slightly expanding stems, straight to slightly convex bases, slightly barbed shoulders, and triangular blades that are either straight or slightly convex (Turner et al. 2011:127). Only one of these specimens is complete; the remainder are broken in

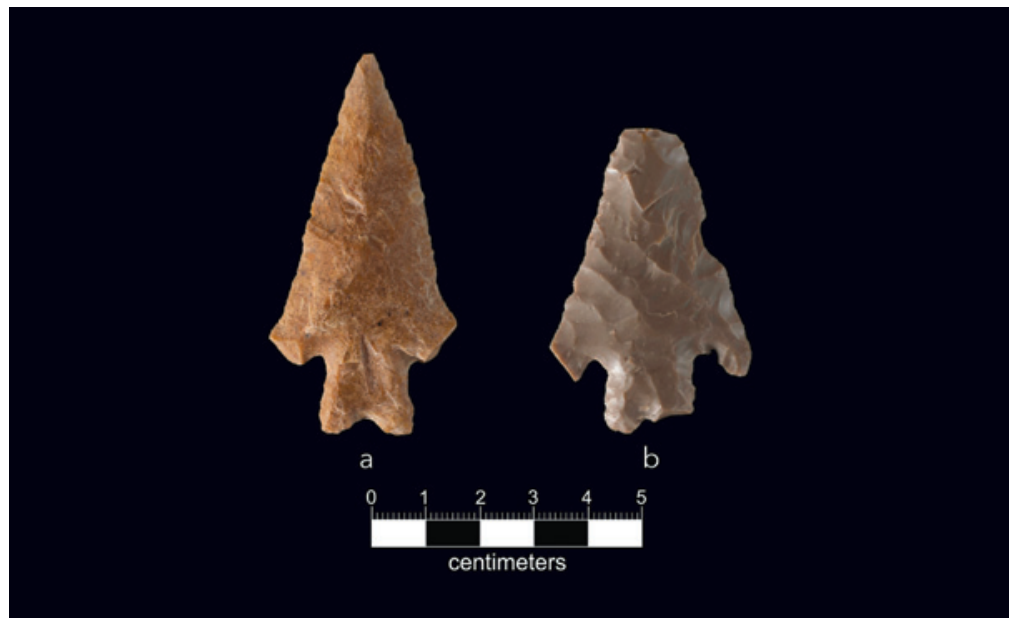

Figure 3-21. Laguna points: (a) Specimen No. 33-1; (b) Specimen No. 159-2. 


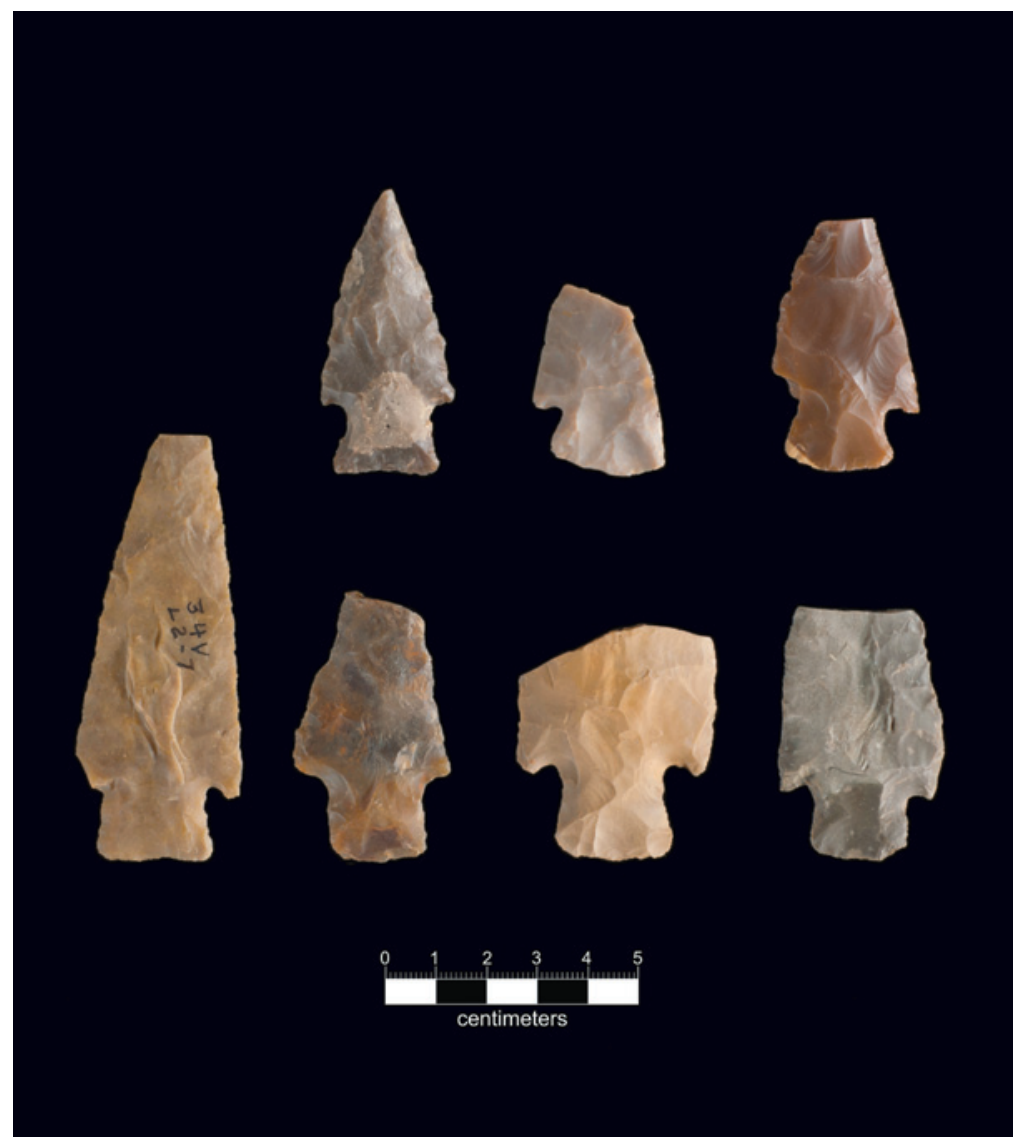

Figure 3-22. Lange points.

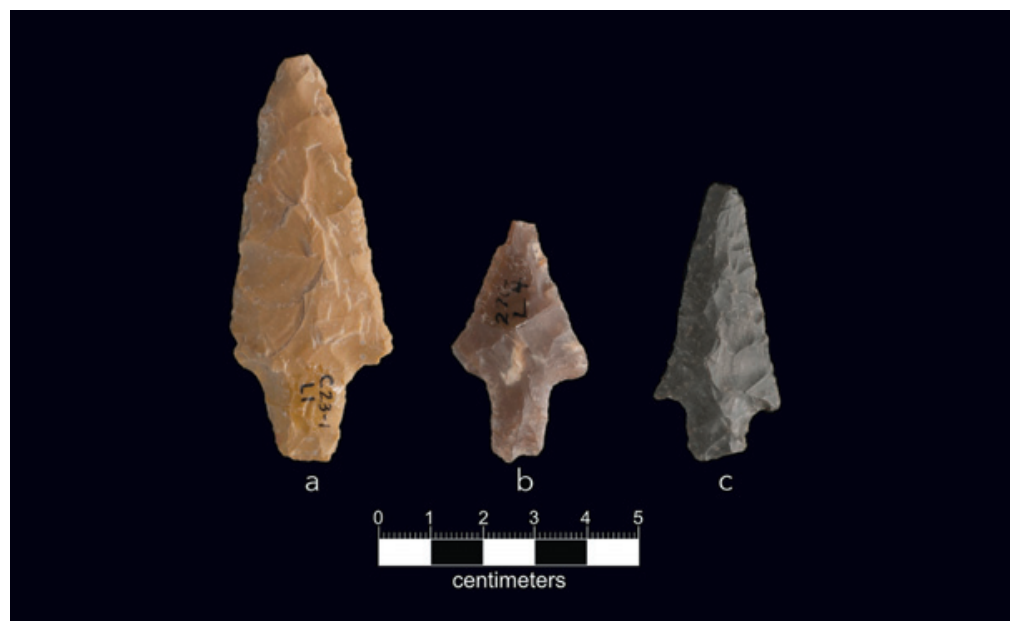

Figure 3-23. Langtry points: (a) Specimen No. 6-1; (b) Specimen No. 164-2; (c) Specimen No. 9-1. various ways, including by impact-snap (2), snaps (5), snap with rejuvenated blade (1), and burned (1).

Lange points resemble points of the Williams type, although Williams has a broader, more rounded base. The expanding stem on Lange also resembles Castroville, but the stems of Lange points are narrower and the points are not barbed. Temporally, they are Late Archaic: Turner et al. (2011:127) place the dates for Lange at around 850-600 B.C. The best Lange data, based on 36 specimens of the type, come from the Eckols site in Travis County (Karbula 2000), although no Williams points were found there. Lohse (2011:203) describes a sample of ten specimens from the Zatopec site in Hays County.

Langtry $(n=3)$

These points, as a group, have relatively long contracting stems, prominent but not barbed shoulders; two have long narrow blades, and the third (Specimen No. 9-1) has a shorter, triangular blade (Figure 3-23). Workmanship overall is good, but within the 41HY147 collection only Specimen No. 9-1 has the thin blade more characteristic of this type. 


\section{Chapter 3}

Langtry points are a minor type in the Late Archaic sequence in the Balcones Canyonlands of Central Texas, but Langtry is a dominant type to the west in the Lower Pecos region where it is well dated. Calibrated radiocarbon dates from Arenosa Shelter, for example, place the type between 2620 and 1480 B.C. (Texas Beyond History, 2011a).

\section{$\operatorname{Marcos}(n=15)$}

As a group these points have deep corner notches, expanding stems, and straight, weakly concave, or slightly convex bases (Figure 3-24). Blades are triangular. Two examples display direct impact fractures, five have snapped breaks, one exhibits a reworked blade, and one is burned.

Marcos points are a Late Archaic diagnostic, often occurring in components with Castroville and Montell (Karbula 2000; Sorrow et al. 1967:145), or with Ensor and Frio. Turner et al. (2011:130) place the dates approximately at 600 B.C. to A.D. 200. Their precise chronological placement is probably between the Castroville and Montell points groups, but an isolated Marcos component has not been encountered.

\section{Marshall $(n=5)$}

Parallel stems and indented bases with prominently barbed shoulders and broad thin blades define the Marshall type

(Figure 3-25). Three

specimens are fragmentary, and Specimen No. 85-2 has an unusual break that has been altered unifacially, probably by stream action since there is no clear indication of intentional modification.

Marshall points are a minor Late Archaic diagnostic occurring slightly later chronologically than Pedernales, which they strongly resemble. The broad blade and barbs also resemble Marcos, but Marshall points differ from Marcos in that the stem edges are straight rather than expanding.

Chronologically, Marshall points date about $1600-1200$ B.C. according to Johnson's

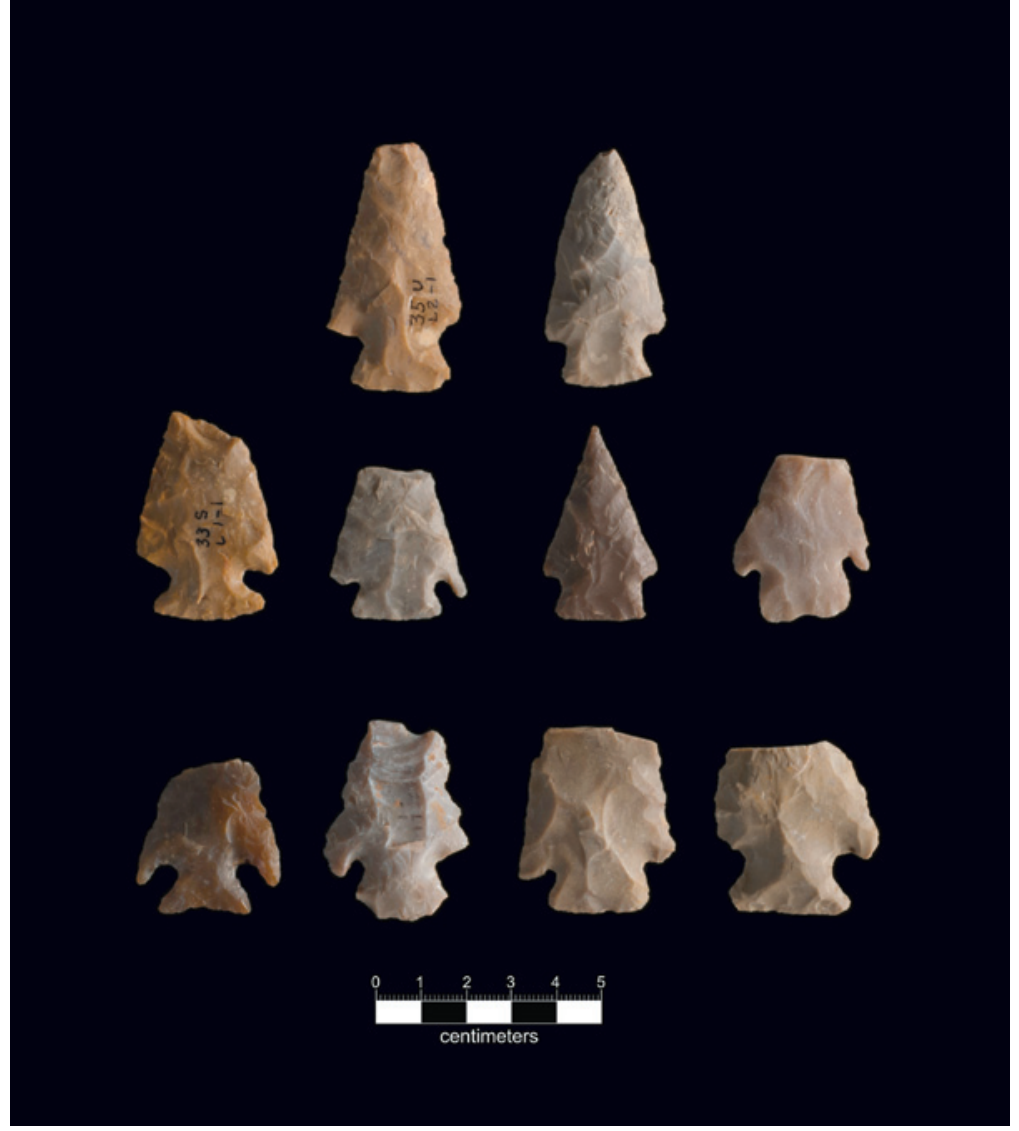

Figure 3-24. Marcos points. 
(1995:Figure 80) model, placing them after Pedernales and before Montell and Castroville. Collins (1998:59, Figure 4-1) places them a bit later in time, but Johnson's placement may be more accurate.

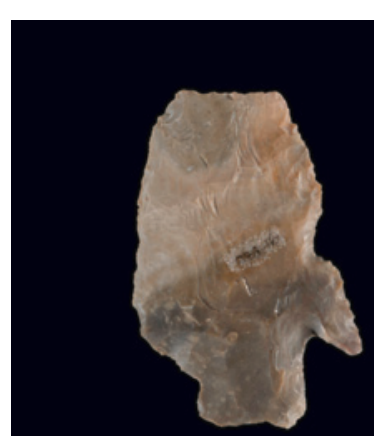

a

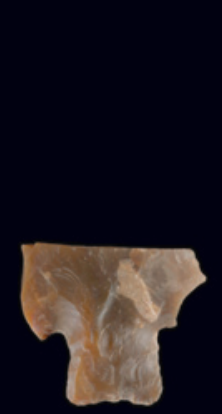

b

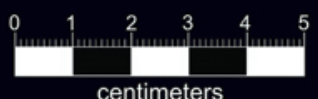

centimeters

Figure 3-25. Marshall points: (a) Specimen No. 288-16; (b) Specimen No. 269-1; (c) Specimen No. 230-1.

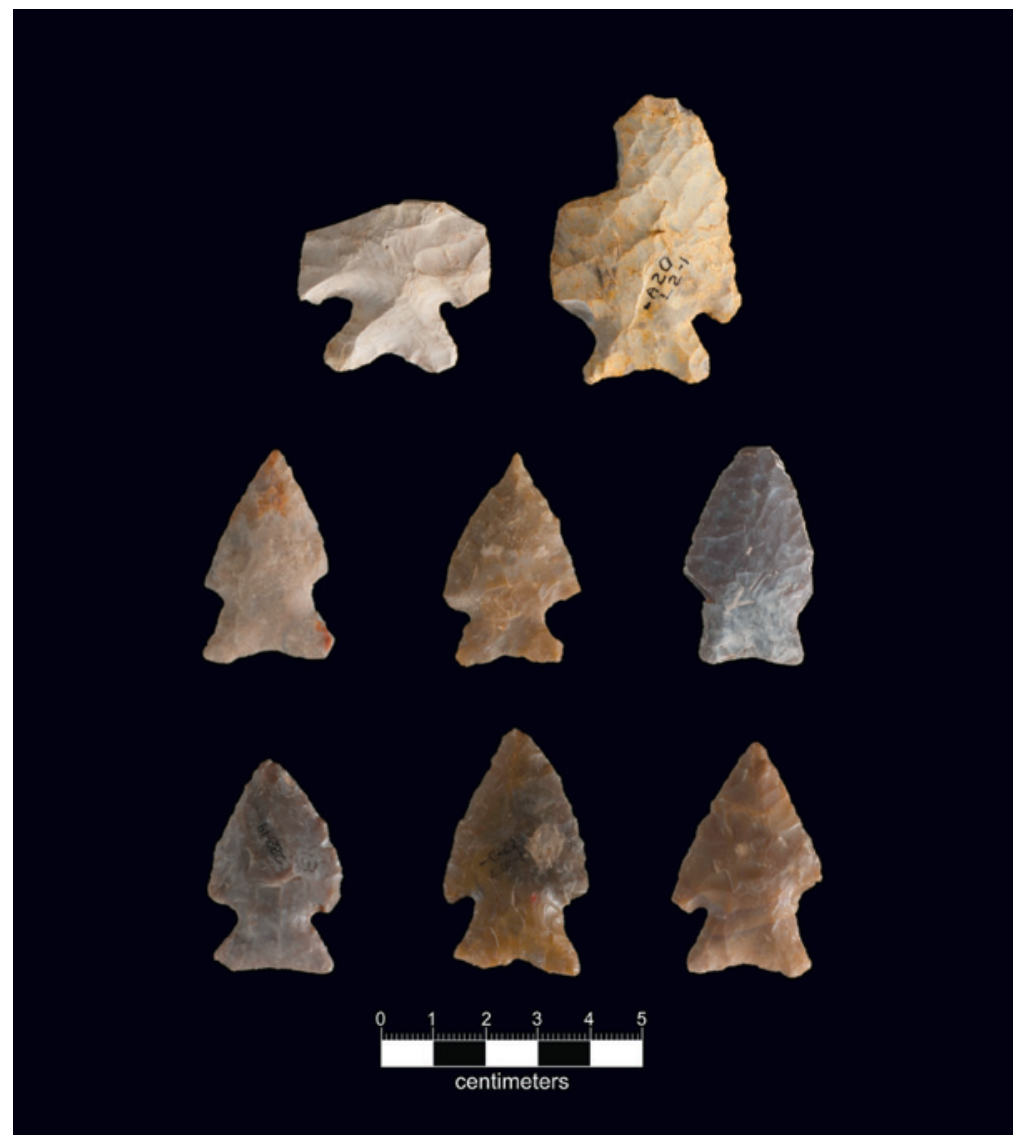

Figure 3-26. Martindale points.

\section{Martindale $(n=8)$}

The Martindale point type (Figure 3-26) is defined by a corner-notched blade with a strongly expanding stem and fishtail-like notched base. Blades are relatively broad and triangular with slightly convex blade edges. Four of these specimens have rejuvenated blades. One specimen displays a direct impact fracture, one blade has a snapped break, and one is burned.

Martindale points are an Early Archaic diagnostic. Their stratigraphic position was first defined at the Landslide site (41BL85) where they occurred in Stratum V with Gower points (Sorrow et al. 1967:Table 1). Subsequently they have been consistently recovered in Early Archaic components. Other good stratigraphic data on Martindale is reported from 41BX377, the Cibolo Crossing site (Kibler and Scott 2000). A large sample of 54 Martindale points was recovered from 41KR621, the Gatlin site (Houk et al. 2008:7-10). Martindale is variously dated from ca. 7000 
to 6000 B.P. (Houk et al. 2008:7). Hester (1971) noted overlap between classic Martindale and classic Uvalde points and used the term "Early Corner Notched" to describe them.

\section{Merrell $(n=1)$}

Specimen No. 176-1 (see Figure 4-29, page 70) is classified as the newly defined Merrell type, given its wide base and deep basal notch (Prewitt 1995:119; Turner et al. 2011:134). In appearance it resembles a Frio with a wide base, but the wide base and blade merit its classification here as Merrell. As is the case for any projectile point type, however, confident classification requires contextual confirmation, which is lacking in this case.

Based on our survey of the literature, the legitimacy and distribution of Merrell points is open to question. Points fitting the general description are rare in Early Archaic components along the eastern edge of the Balcones Escarpment (Prewitt 1995:119), and only a very few have been recognized. Individual specimens from the Merrell (Campbell 1948:Plate 3-9) and Landslide sites (Sorrow et al. 1967:Figure 15d) differ markedly from points labeled as Merrell at the Varga site (Quigg et al. 2008:Figure 11-19). In fact, Quigg et al. classify apparently identical point styles differently in their report, as Gower in their Figure 11-14 and as Merrell in their Figure 11-19. The single Merrell point at the Landslide site (miscellaneous dart point J) was recovered from the same deposit that yielded Bell, Early Triangular (Untyped Group 3), and Martindale (Sorrow et al. 1967:Table 1), hinting at the chronological position for this type.

\section{Montell $(n=13)$}

Montell points (Figure 3-27) are distinguished by a V-shaped notch in the base, straight to slightly expanding stem, small barbs, and thin triangular blade. The point resembles Castroville in form and technology except that the latter has more prominent barbs and does not have the V-shaped notch. Eight specimens display direct impact fractures; of these, four have snapped blades. Snapped blades occur on three others. The blade on one is reworked, and one specimen is burned. One specimen (No. 267-2) is a manufacturing failure and was aborted due to stacked step fractures during thinning.

Montell points typically co-occur with Castroville points and are a dominant type across much of the Edwards Plateau and adjacent parts of the Gulf Coastal Plain. The date range for Montell points is about 700-800 B.C. (Turner et al. 2011:71, 72). Calibrated radiocarbon dates from Bone Bed 3 at Bonfire Shelter, the Castroville/Montell component, yielded four dates that averaged 2645 B.P. (Turner et al. 2011:71). The Culebra Creek site (41BX126) produced two uncalibrated dates of 2700 B.P. and 2780 B.P.. (Nickels et al. 2001:219).

\section{Nolan $(n=18)$}

The Nolan type (Figure 3-28) is characterized by square stems beveled to the right, left, or unifacially; thin bases; rounded-to-square shoulders; and long, narrow triangular blades that may be slightly inwardly recurved. One specimen (No. 137-1) has the blade twisted slightly 
to the left like Pandale. Impact fractures represented by direct impact and snap fractures are common (represented by a total of 11 examples) within the assemblage. Three have rejuvenated blades, and one (No. 183-2) has a reworked blade that may have been a drill.

Nolan points are a regional Middle Archaic diagnostic in the eastern and southern Balcones Canyonlands (McKinney et al. 1998). Their distribution is generally south of the Lampasas River and into Edwards County; beyond Edwards County to the west Pandale points are coeval with Nolan, which is a minor type in the Lower Pecos region (Prewitt 1995:123). Together with the abundant Early Triangular and Travis points (see below), the frequency of this type identifies Spring Lake as a major locality within the region during the Middle Archaic period.

At 41BX11, dates for Nolan generally fall at ca. 3560 B.P. (Lukowski 1988:17), at the late end of its time span. Two uncalibrated dates were obtained from the Nolan component at 41BX126, the Culebra Creek site, of $4630 \pm 40$ B.P. and $4949 \pm 50$ B.P. (Nickles et al. 2001:115, 116). The stratigraphic position places Nolan later than Bell/Andice/Early Triangular at the Landslide site (Sorrow et al. 1967:Table 1). Recent excavations at 41ME147, the Eagle Bluff site, have found Nolan points overlying a deposit with La Jita points, with Early Triangular points below (Hester 2011:3).

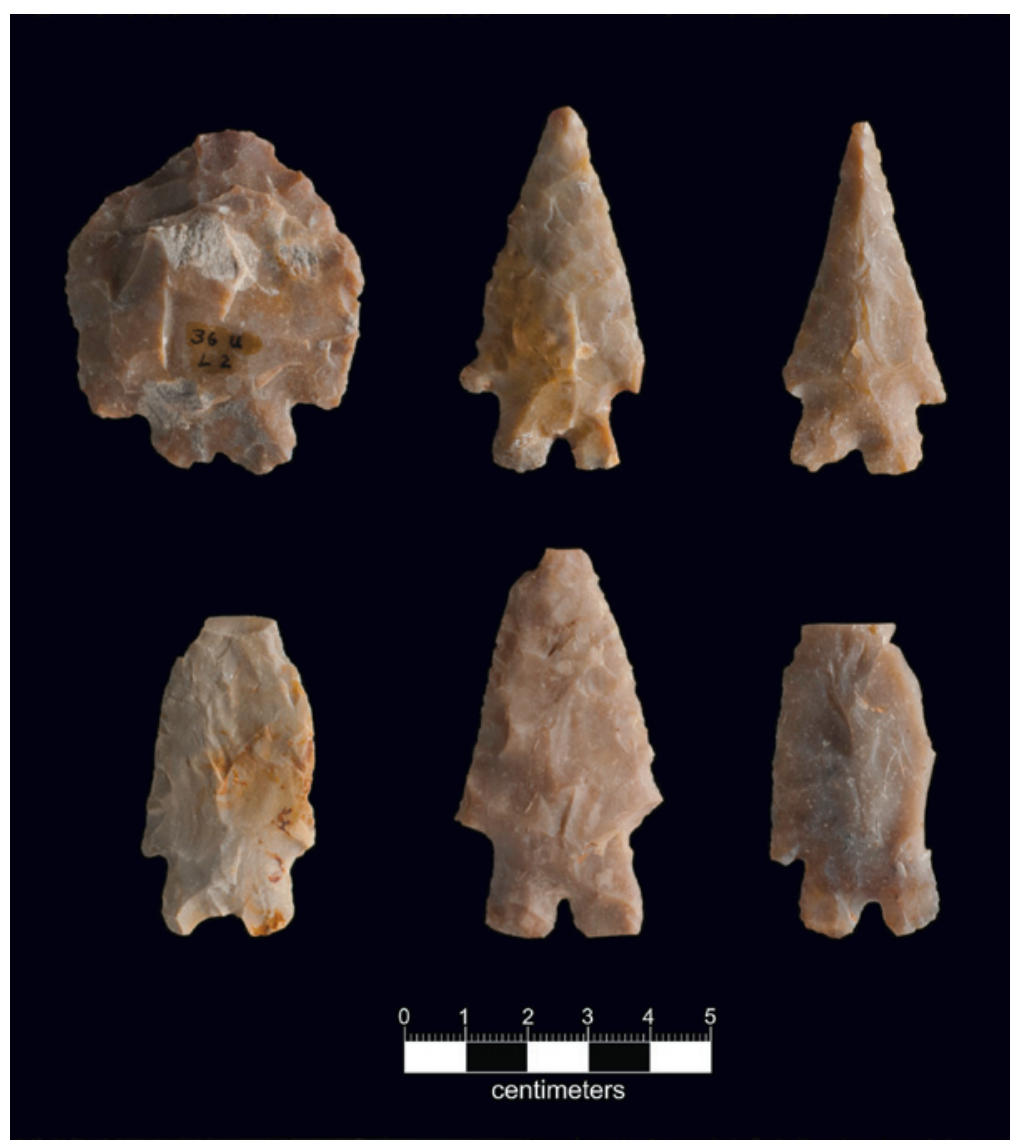

Figure 3-27. Montell points.

\section{Pedernales $(n=23)$}

Pedernales points are distinguished by mostly parallel stems and indented bases (Figure 3-29). Shoulders range from slight to barbed, but typically have only small barbs. Blades can be long, triangular or recurved, with needle-like tips. Considerable variation is seen in the base indentions, varying from V-shaped to U-shaped. One distinguishing technological characteristic of Pedernales is that the stem is fashioned first (sometimes thinned with a flute on both faces), before the blade is thinned. The thickest part of this point is usually at the base of the stem. 


\section{Chapter 3}

The present sample displays many of the formal attributes of the type as defined by Suhm et al. (1954) and Turner et al. (2011). Retooling is evident in nearly half the sample. Ten display direct impact fractures at the distal end; two of these also have snap breaks; and snap breaks appear on six additional examples. Blades were rejuvenated on three. Two are burned.

Pedernales is the most widespread Late Archaic type in Texas, extending from the Lower Pecos as a minor type eastward along the southern and eastern edge of the Edwards Plateau, where it is a dominant type, onto the Gulf Coastal Plain to the mouth of the Colorado and Brazos Rivers, and south to near Laredo, as a minor type (Prewitt 1995:125). Pedernales points date approximately to 1800-1200 B.C. or 4200-3800 B.P., based on radiocarbon dates from a nearly pure Pedernales component at 41WM13, the Bessie Kruze site (Johnson 2000:56-60).

In a regional comparison of Pedernales stem and blade forms, Tomka et al. (2003) studied collections from sites in two clusters of Texas counties. The southwest cluster included Uvalde, Bandera, and Bexar Counties; the north cluster encompassed Bell, Williamson, and Milam Counties. More than 600 specimens were sorted on the basis of stem and blade characteristics. Stem forms were divided into six groups, and blades were sorted in three morphological groups. The description of the stem and blade groups from the 2003 investigation, which did not include artifacts from Hays County, is beyond the scope of this study. However, since Hays County lies between the two clusters of sites in that investigation, we have sorted the $41 \mathrm{HY} 147$ sample and compared it to data presented by Tomka et al. (2003)

Stem form 1 , which is a parallel stem with moderately indented base, dominated the $41 \mathrm{HY} 147$ collection with nine specimens. Stem form 2, a barrel-shaped stem with more deeply indented base, was represented by three examples, and stem forms 4 (parallel with deeply indented base) and 6 (barrel shape slightly contracting and deeply indented base) are each represented by

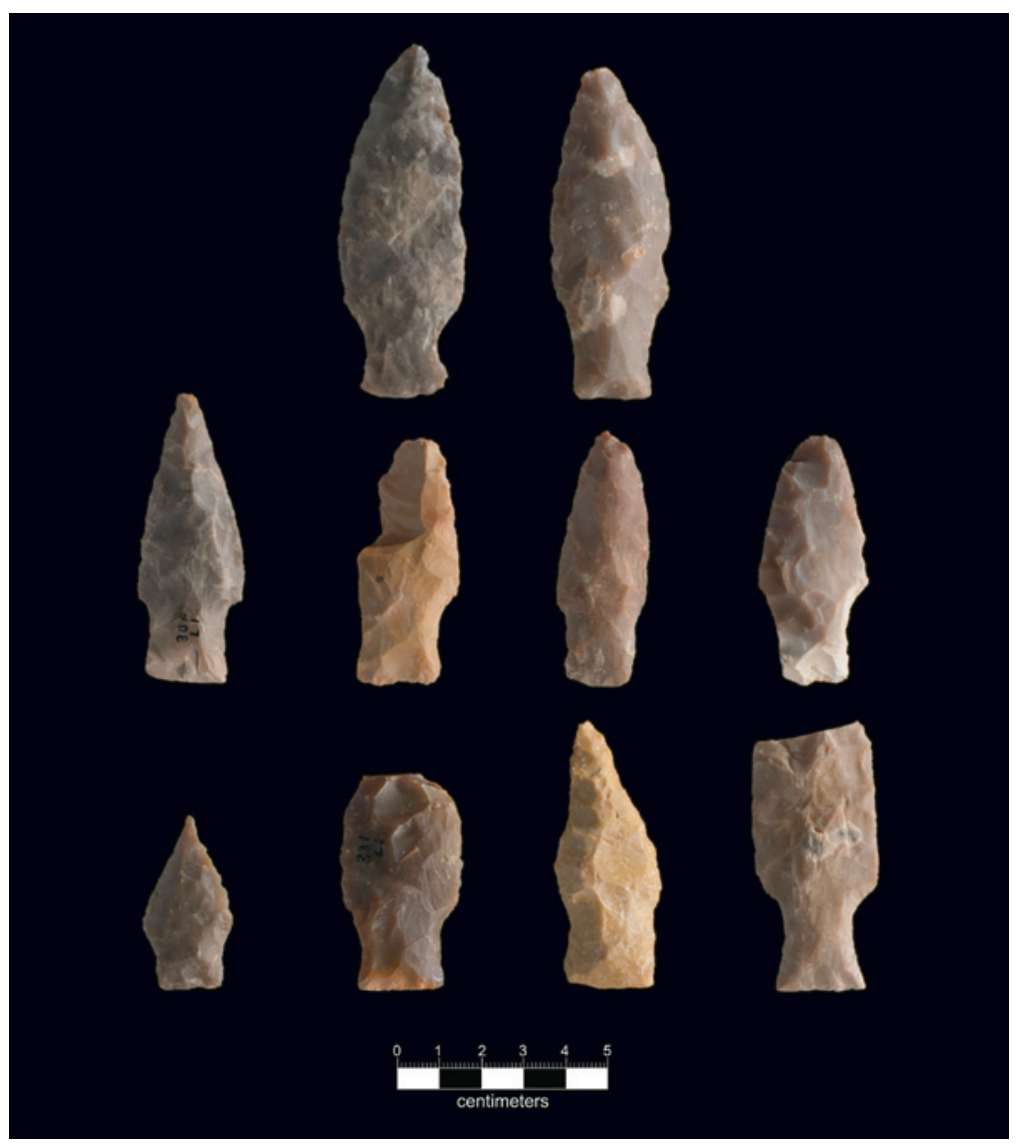

Figure 3-28. Nolan points. 
two examples. The pattern of variation is closer to the northern cluster, in which stem form 1 is popular, and differs from the southwest cluster, in which stem forms 2,3 , and 4 are more common (Tomka et al. 2003:142).

The blade form seen in the Hays County sample also differs from the southwest and north clusters, with most specimens from this collection falling between blade types 1 and 3 of Tomka et al. by having wide blades that are either shouldered or slightly barbed. Although the implications of these stem and blade variations is unclear, it can be noted that the broad distribution of Pedernales is comparable to that of Perdiz in that the same point type is used over a very broad area at the same chronological moment in time. Although the geographic ranges of Pedernales and Perdiz differ, it is interesting that bison were present during each interval. Tomka et al. (2003:144) dismiss the variation as merely "homogeneous Pedernales manufacturing strategies" or "regional variability in classifying Pedernales." It is possible that the stylistic variation in Pedernales across the Central Texas landscape may be the result of the same kinds of social interaction suggested by Arnn (2012) for the Toyah phenomenon.
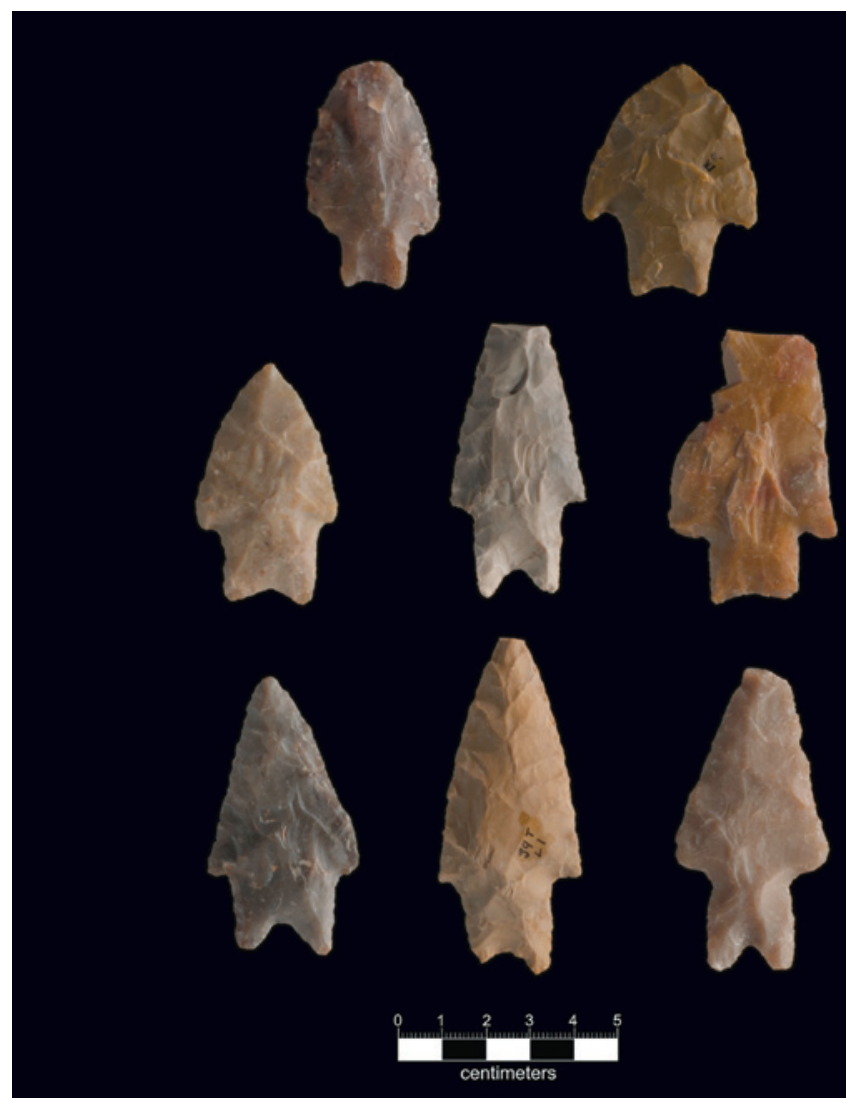

Figure 3-29. Pedernales points.

\section{San Patrice $(n=1)$}

The San Patrice point from the Aquarena Springs site (see Figure 4-17, page 66) readily conforms to the established type description as it has a short triangular blade, side notches, and deeply indented base creating the characteristic basal corners. The base is thinned but not fluted. The basal corners of these points suggest ears on the silhouette of a wolf's head, leading some East Texas collectors to dub the type Wolfshead, for which the Wolfshead site (which has a San Patrice component) in San Augustine County was named (Duffield 1963).

San Patrice points are generally short, the result of distal reworking, and 


\section{Chapter 3}

have thinning flakes along the base that sometimes approximate fluting, although parallel longitudinal flakes are equally common. Traditionally considered to date to the Paleoindian period in East Texas, they are also found in Louisiana, and as far north as Missouri (Jennings 2008; Turner et al. 2011:158).

Variations of San Patrice include the larger Brazos Fishtail and/or Rodgers Side Hollowed points in the Brazos Valley north to the Panhandle. Occasionally, however, more typical San Patrice points are found in excavations in Central Texas. For example, Collins (1998) reports five San Patrice points from the Wilson-Leonard site.

\section{St. Mary's Hall $(n=32)$}

This Middle to Late Paleoindian point type (Figure 3-30) is distinguished by a long, lanceolate form with relatively narrow blade, parallel to weakly tapering stem, and very fine obliqueparallel pressure flaking. Bases on some are thinned by short flute-like flakes and are slightly concave (rarely more than $5 \mathrm{~mm}$ ). Stem edges are lightly dulled. Blade morphology is so distinctive, because of the narrow blade and oblique-parallel pressure flaking, that distal and medial fragments can be accurately typed.

St. Mary's Hall points were first recovered from an excavated context at the St. Mary's Hall site in San Antonio in 1977. At the time, they were included in the broadly defined Plainview category (Hester 1991).

Later, when excavated at the Wilson-Leonard site (Collins 1998), they were sorted into a separate type, to which the St. Mary's Hall name was applied.

The chronological placement of St. Mary's Hall is becoming clearer. The Center for Archaeological Research at The University of Texas at San Antonio recently obtained a calibrated radiocarbon date of 10,490-10,230 B.P. on a

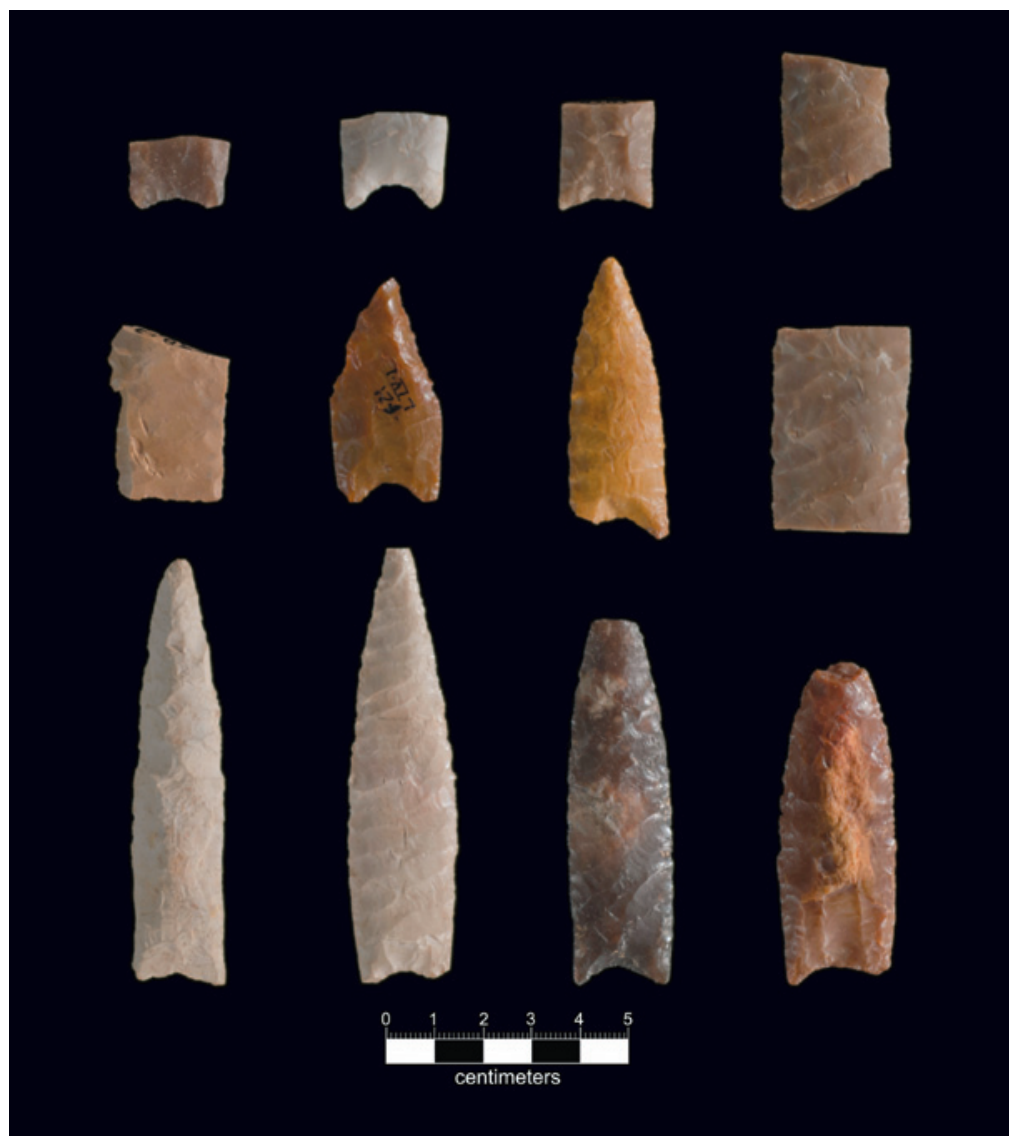

Figure 3-30. St. Mary's Hall points. 
well-stratified St. Mary's Hall component at Brackenridge Park in San Antonio (Ulrich 2011). Previously Collins (1998:328) applied radiocarbon data from Wilson-Leonard to suggest that the St. Mary's Hall type dated between 9990 B.P. and 8700 B.P. Collins further indicated that Plainview points at that site date earlier, between 11,000 B.C.and 10,100 B.C..

The Aquarena Springs site has one of the largest samples of St. Mary's Hall points thus far recorded, exceeded only by the hundreds from the Wilson County Sand Pit, a sand-mining operation where thousands of unprovenienced artifacts were recovered during sand and gravel sorting processes (Pfeiffer 2001).

Geographically, St. Mary's Hall points occur in the southern Edwards Plateau (another example is the Granite Beach site in Llano County [Crawford 1965]) and adjacent Gulf Coastal Plain in south-central Texas. Specimens are also documented from the Hog Eye site in Bastrop County and the Golden Sands site in Lee County (Turner et al. 2011; Hester 2012).

\section{Travis $(n=16)$}

This sample of Travis points includes specimens that have narrow triangular blades with convex lateral edges (Figure 3-31). Shoulders are rounded, varying from faint to fairly

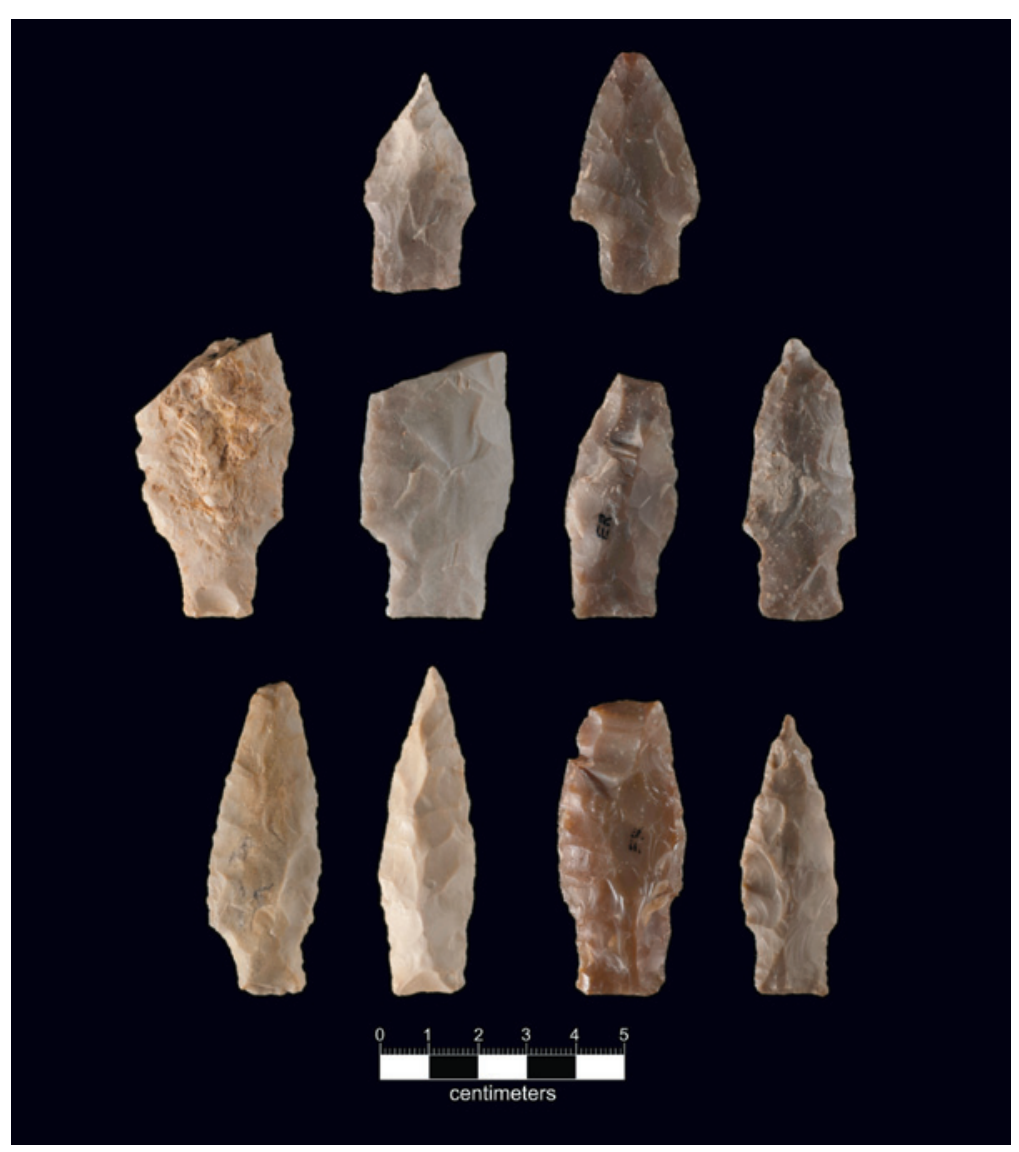

Figure 3-31. Travis points. prominent. The stem is usually square with parallel edges; stem edges are not beveled, as is seen on Nolan points with which they co-occur. Five specimens from this sample exhibit reworked blades; five show snap fractures, probably from impact; two have direct impact breaks; and two show evidence of burning.

Travis points are similar to Evant, although they generally lack the more rectangular stem of the latter. The geographic distribution also differs, as the geographic range for Evant occurs more to the north of Travis in Central Texas (Turner et al. 2011:98). 


\section{Uvalde/Gower $(n=11)$}

The combined Uvalde/Gower name is used here because both types are characterized by a strongly bifurcated stem and slight to moderate shoulders; some may have small barbs (Figure 3-32). Blades are relatively thick, and, in contrast to other point types such as Bandy, the workmanship is not refined. Eight of these 11 specimens display snap fractures, and two are broken by impact. Blade rejuvenation occurs on two, and one is burned.

The senior author believes Uvalde and Gower may be variations of the same type, although the junior author believes they are distinct types in the Balcones Canyonlands. The main difference between Uvalde and Gower may in part be the result of analyst preference, in part analyst perception, or in part geographic variation rather than differences in morphology. However, morphological variations are apparent when larger samples, such as those from the Varga site (Quigg et al. 2008:Figure 11-14) and Gatlin site (Houk et al. 2008:Figure 6), are compared to specimens from the Landslide site (Sorrow et al. 1967:Figure 12a-c) and Youngsport site (Shafer 1963:Figure 7). Uvalde and Gower occur at some sites within the same chronological interval (e.g., at the Landslide site) and date ca. 6300-5200 B.P. based on the dates for the Early Archaic component at the Varga site (Quigg et al. 2008:542, 543), which yielded numerous examples of points we would classify as Uvalde and Gower. The Gatlin site also yielded a series of dates on the Gower component; these were: 5320 5050 B.P., 7150-7130 B.P., and 7020-7420 B.P. (Smith and Oksanen 2008:Table 7-2). A date of 5820 B.P., linked to a Uvalde point, comes from 41ME147. The charcoal sample is from an earth oven in a bluff, carefully excavated by the Southern Texas Archaeological Association.

Uvalde points have a U- to V-shaped basal notch and slightly expanding basal corners, in contrast to Gower, with U-shaped to wide U-shaped notches and rounded stem edges that only

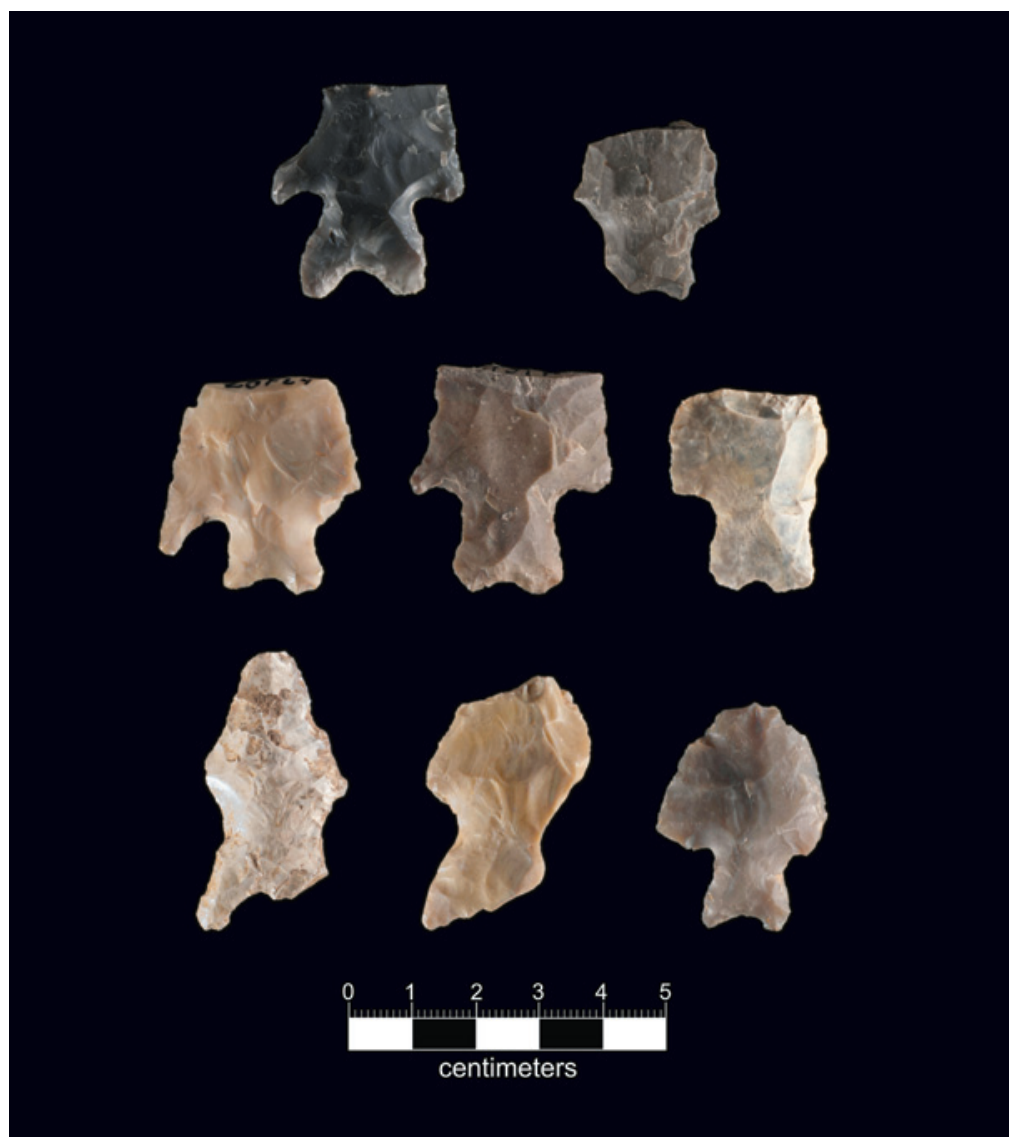

Figure 3-32. Uvalde/Gower points. 
occasionally expand. Moreover, Gower is often recognized by the arc-shaped flaking that forms the basal edge. Of course, during the use-life of specimens from these two types, reworking or breakage can sometimes make the types difficult to identify, as for example in Johnson's (1991:105-108) treatment of dart points at the Sleeper site, wherein his Early Split Stemmed points are subdivided into Uvalde and Gower subgroups. From our perspective, all fall within the range of the Gower type.

\section{Val Verde-like $(n=1)$}

Typical of the Lower Pecos, thin Val Verde points are similar to Langtry, but have a wide, expanding stem. They are contemporary with Langtry, late Middle to Late Archaic in age. They are rare in Central Texas assemblages. Because Specimen No. 288-44 from 41HY147 may not actually be derived from the Val Verde type, it has been classified as Val Verde-like (Figure 3-33).

\section{Williams $(n=3)$}

Williams points (Figure 3-34) are notable for their broad bodies with bulbous stems with rounded bases. In some cases, they overlap with Lange and are difficult to separate. Though

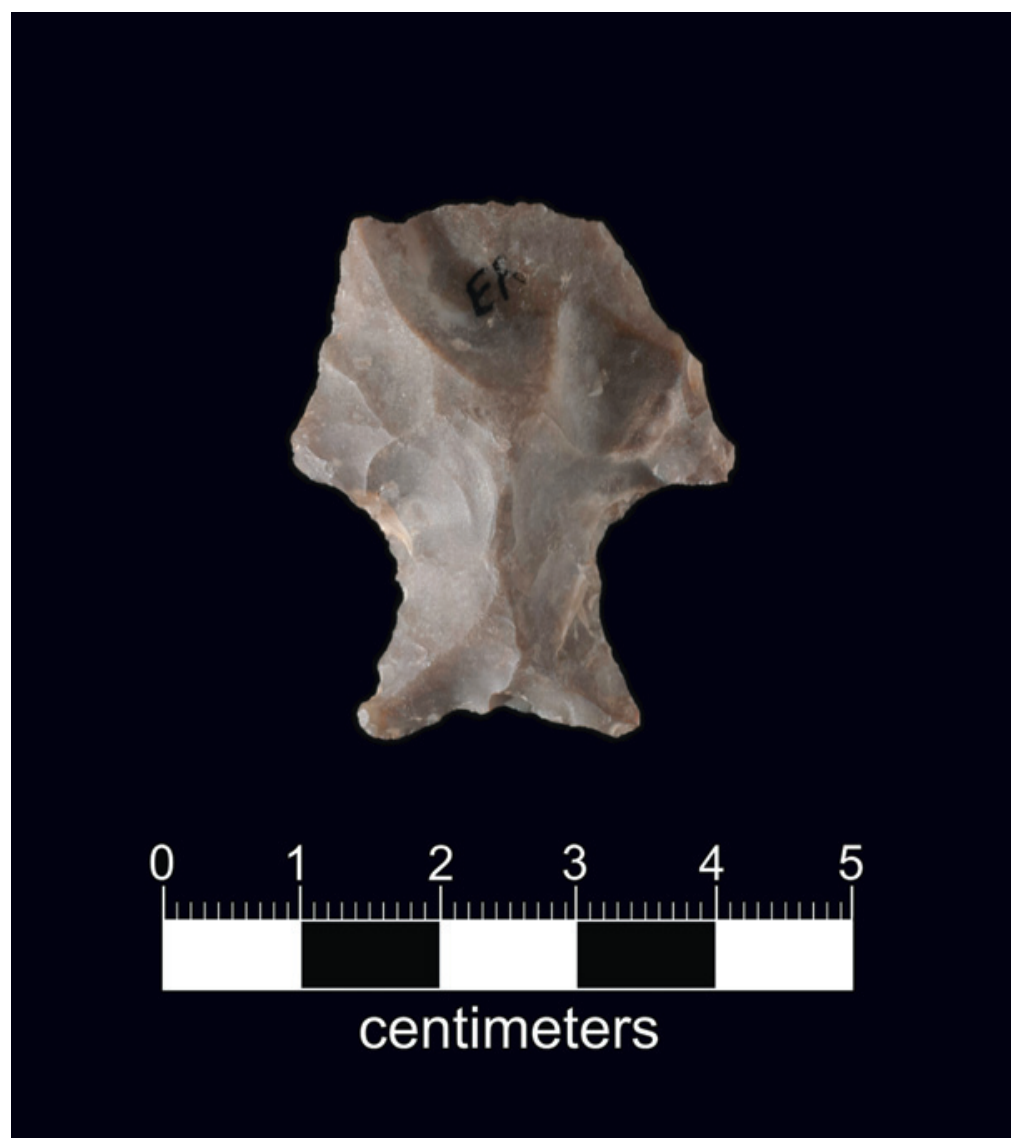

Figure 3-33. Val Verde-like point, Specimen No. 288-44.

\section{Williams points occur in}

small numbers at most sites, Kelly (1961:251) reported 11 specimens from the Crumley site. Black and McGraw (1985:322) were able to tie the specimens from the Panther Creek site to Local Period 8, associated with Montell, Castroville, and Marcos.

\section{Wilson $(n=6)$}

Wilson points are characterized by thick, sometimes biconvex, bodies and wide expanding stems with straight to slightly concave bases. The stems have grinding on all edges and are thinned by two or more vertical flakes. Shoulders are prominent to slightly barbed. Some 
regional variation is seen in thickness and stem length between specimens of the Lower Pecos and those of Central Texas.

Among the Wilson points (Figure 3-35) from Spring Lake, the blade on a complete point (Specimen No. 51-1) has a slight twist to the left. Blades on two (Specimen Nos. 50-1 and 53-1) have been extensively reworked; this alteration completely removed the shoulders on Specimen No. 50-1 and nearly so on No. 53-1. Two specimens (Nos. 90-1 and 237-1) exhibit direct impact fractures.

Wilson points were first described by Weir (1985) from the Wilson-Leonard site near Austin. These points were originally referred to as Early Stemmed (Turner and Hester 1985), but the formal name, Wilson, began to be widely applied in the 1990s (Collins 1998; see also Turner et al. 2011). It was not until the Wilson-Leonard project that numerous specimens were excavated and were placed in a time frame of $9500-10,000$ B.P. (Dial et al. 1998:376$382)$.

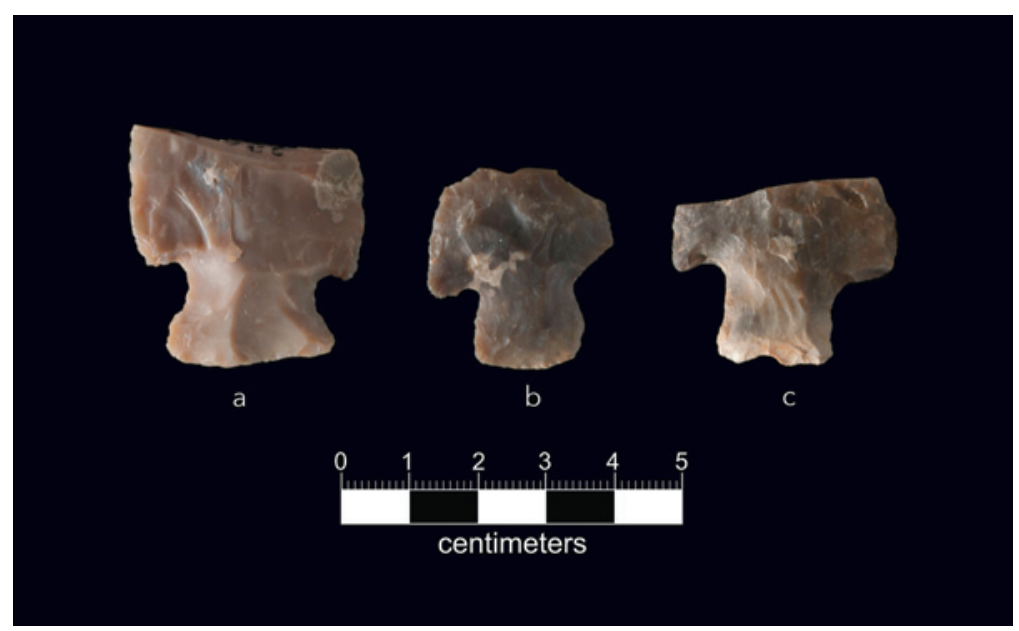

Figure 3-34. Williams points: (a) Specimen No. 104-1; (b) Specimen No. 251-1; (c) Specimen No. 65-2.

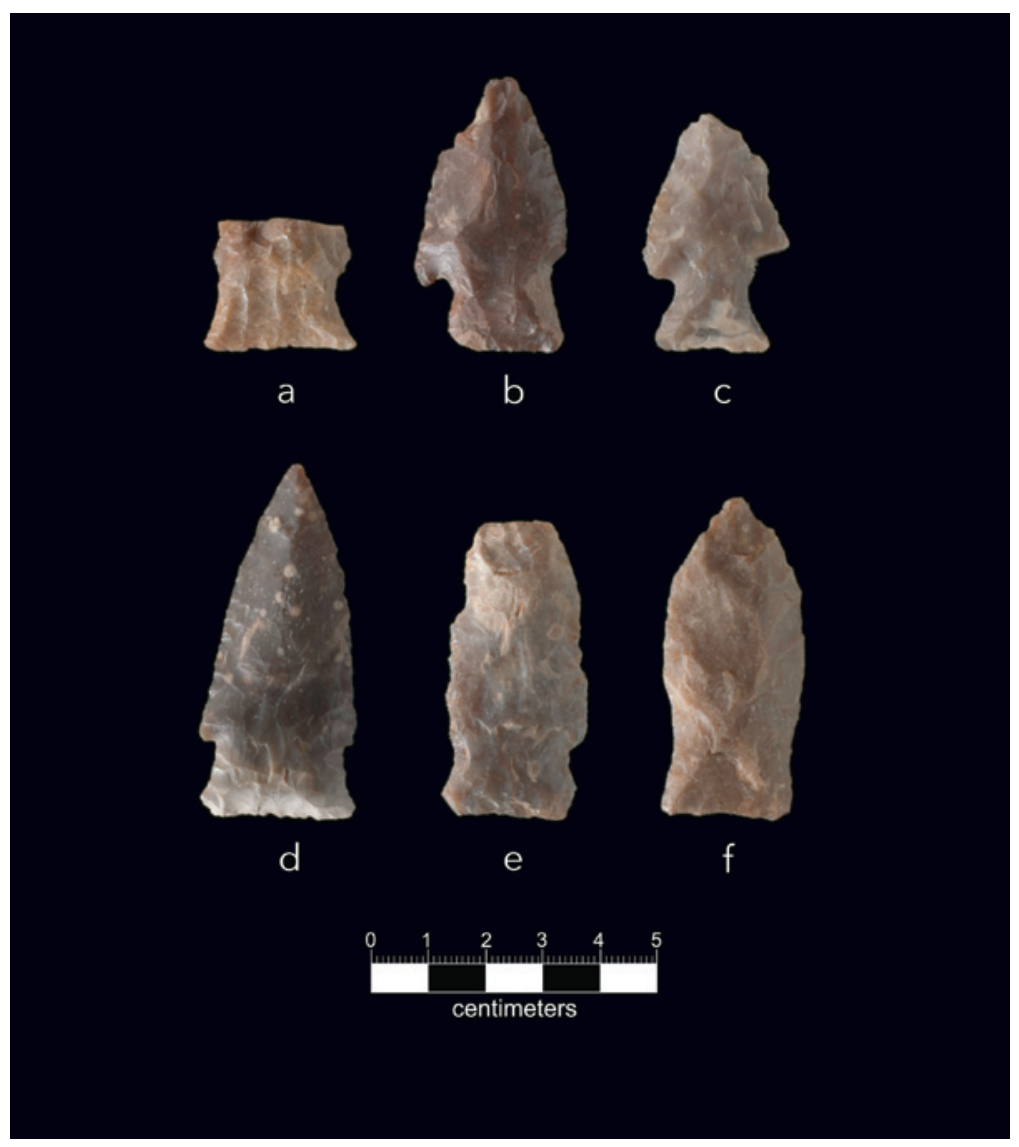

Figure 3-35. Wilson points: (a) Specimen No. 241-1; (b) Specimen No. 237-1; (c) Specimen No. 90-1; (d) Specimen No. 51-1; e: 53-1; (f) Specimen No. 50-1. 


\section{Untyped and Unclassifiable Dart Points $(n=20)$}

This group includes points that either do not fit any conventional type or are so badly damaged as to prevent confident classification (Figure 3-36). Specimen No. 8-2 has a rudimentary short stem with moderately barbed shoulders. The blade appears to be unfinished, as does the tip. This is probably a manufacturing reject. Seven specimens are thermally fractured, and one specimen was made from a broken distal fragment.

\section{Dart Point Fragments $(n=162)$}

A large number of artifacts represent unclassifiable fragments of projectile points. These include proximal, medial, and distal sections that for various reasons lack distinguishing characteristics that would permit more confident classification. The sample probably includes point fragments from every time interval as well as late stage preforms that in sorting could not be distinguished from finished point fragments. No further classification has been attempted on these artifacts.

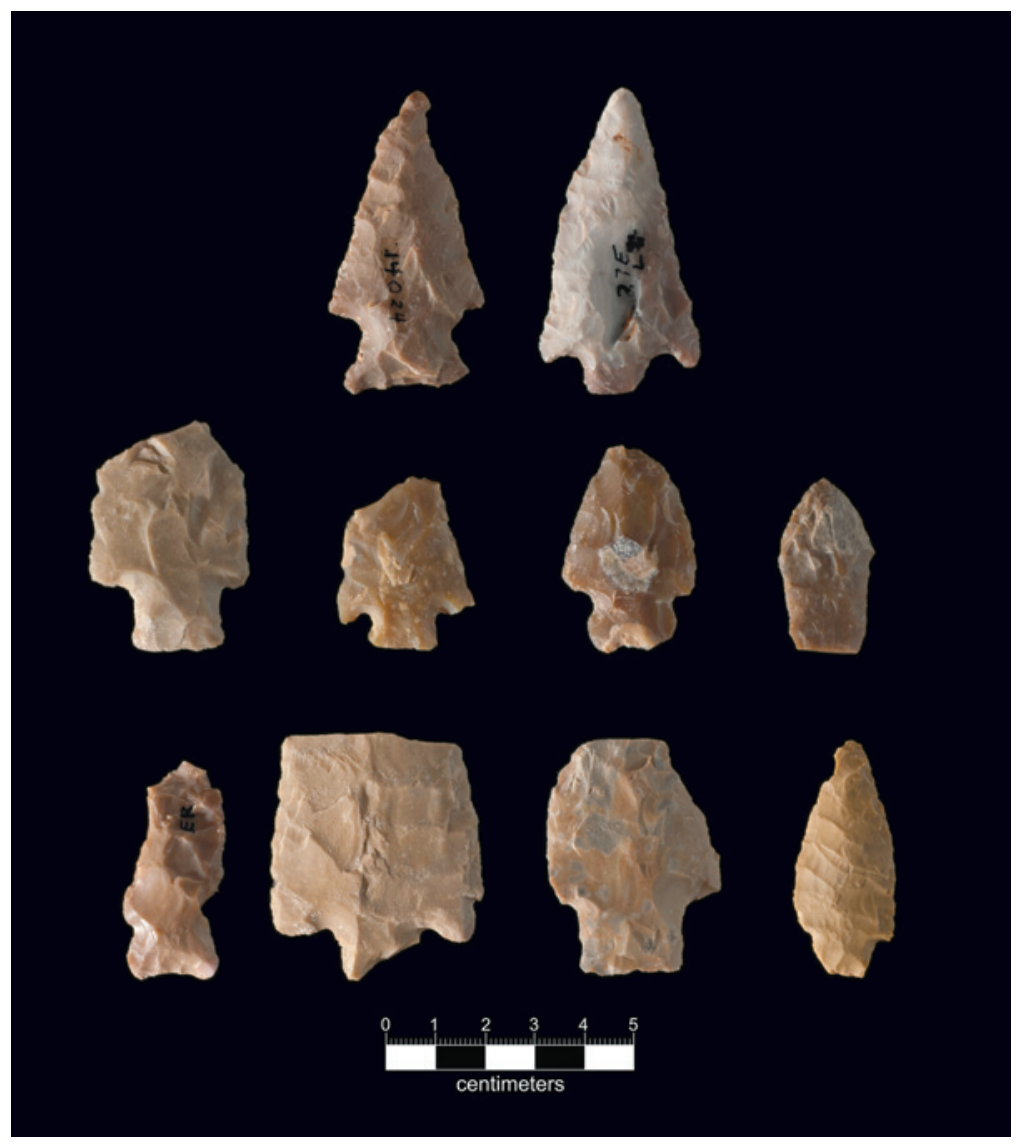

\section{Arrow Points}

Specimens from the $41 \mathrm{HY} 147$ collection selected for analysis include six arrow points (Figure 3-37).

\section{Edwards $(n=2)$}

The Edwards specimens (Figure 3-37d-e; also see Figure 4-61, page 82) are among the largest of the arrow points and appear to be the earliest form in the Balcones Canyonlands. They have straight to convex lateral edges that are frequently serrated and occasionally recurved. The prominent shoulders or barbs are pointed, and the expanding stem is deeply divided and recurved, producing projections

Figure 3-36. Ten untyped dart points from 41HY147. 


\section{Chapter 3}

that may curve upward or downward.

Edwards points were first defined by Sollberger (1967). Geographic distribution of the type extends from Hays County on the eastern periphery westward to Edwards County and the upper Nueces River Valley. The type is not commonly found in the Lower Pecos area. The earliest Edwards points at the Rainey site (Henderson 2001:277) come

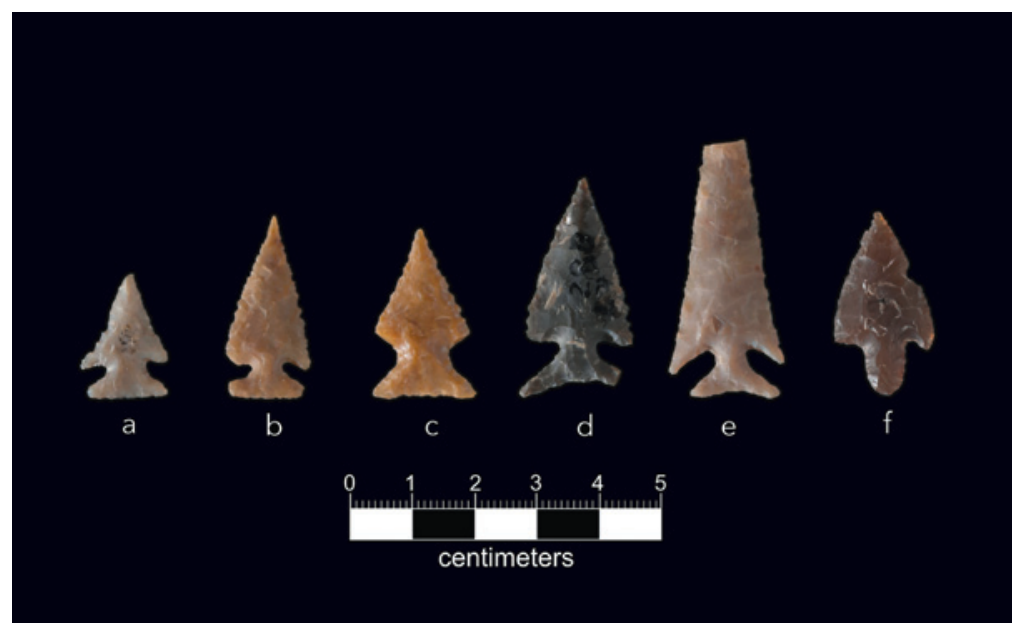

Figure 3-37. Arrow points. Scallorn type: (a) Specimen No. 310-4; (b) Specimen No. 291-1; (c) Specimen No. 151-2. Edwards type: (d) Specimen No. 43-2; (e) Specimen No. 288-48. Perdiz type: (f) Specimen No. 310-5. from a zone that, although not directly dated, occurs stratigraphically immediately below a date of A.D. 938-1025. Based on the Rainey site data, Scallorn and Sabinal arrow points may be in part coeval with Edwards.

\section{$\operatorname{Perdiz}(n=1)$}

This single Perdiz point (Figure 3-37f; also see Figure 4-62, page 83) has a barbed blade, slightly convex stem edges (one of which is damaged), and a slightly contracting stem with a rounded base. It readily conforms to the type as originally defined by Suhm et al. (1954:504).

Perdiz points are a diagnostic trait of the Toyah period and date from ca. A.D. 1300 to the early 1700s (Walter 2007:107). Two calibrated radiocarbon dates from a lower Perdiz component (IVe) at the Rainey site (41BN33) were A.D. 1207-1265, and A.D. 1186-1278 (Henderson 2001:277). These dates are earlier than expected and may not accurately date the first appearance of Perdiz points, although they probably do provide a maximum date for the point type. A calibrated date from the Black Vulture (41BN207) Toyah component is A.D. 1480-1660 (Clint McKenzie, personal communication 2012).

\section{Scallorn $(n=3)$}

These three arrow points (Figure 3-37a-c; also see Figure 4-60, page 82) fit the description of Scallorn as originally defined by Suhm et al. (1954:506). They have straight bases, deep corner notches, and finely pressure-flaked blades. One critical technological variable noted on Scallorn points is that they are bifacially made from triangular preforms.

Scallorn points are diagnostic of the Austin Phase and are recognized as the earliest arrow points in the core area of Central Texas. They typically date ca. A.D. 800-1200 (Prewitt 1983). 


\section{Arrow Point Fragments $(n=4)$}

These are thin, delicately flaked bifaces that are undoubtedly arrow point fragments. The fragmentary state precludes further classification into known types.

\section{Other Stone Tools And Artifacts}

Specimens from this collection that we evaluated also contained numerous tools other than projectile points. Brief descriptions of these artifacts are provided here.

\section{Multipurpose Bifacial Tool $(\mathrm{n}=1)$}

Specimen No. 14-1 (Figure 3-38) is a long, parallel-sided, well-made biface with a reworked tip that is slightly beveled to the left. The tool may have been a projectile point, although this possible function seems questionable inasmuch as the wider end appears to have been the working end of the tool. The wider end has a distinctive bifacial retouch that created a bitlike edge with an approximate angle of 60 degrees (measured with a goniometer). Slight edge damage and polish are also apparent at this end.

\section{Large Drills $(n=8)$}

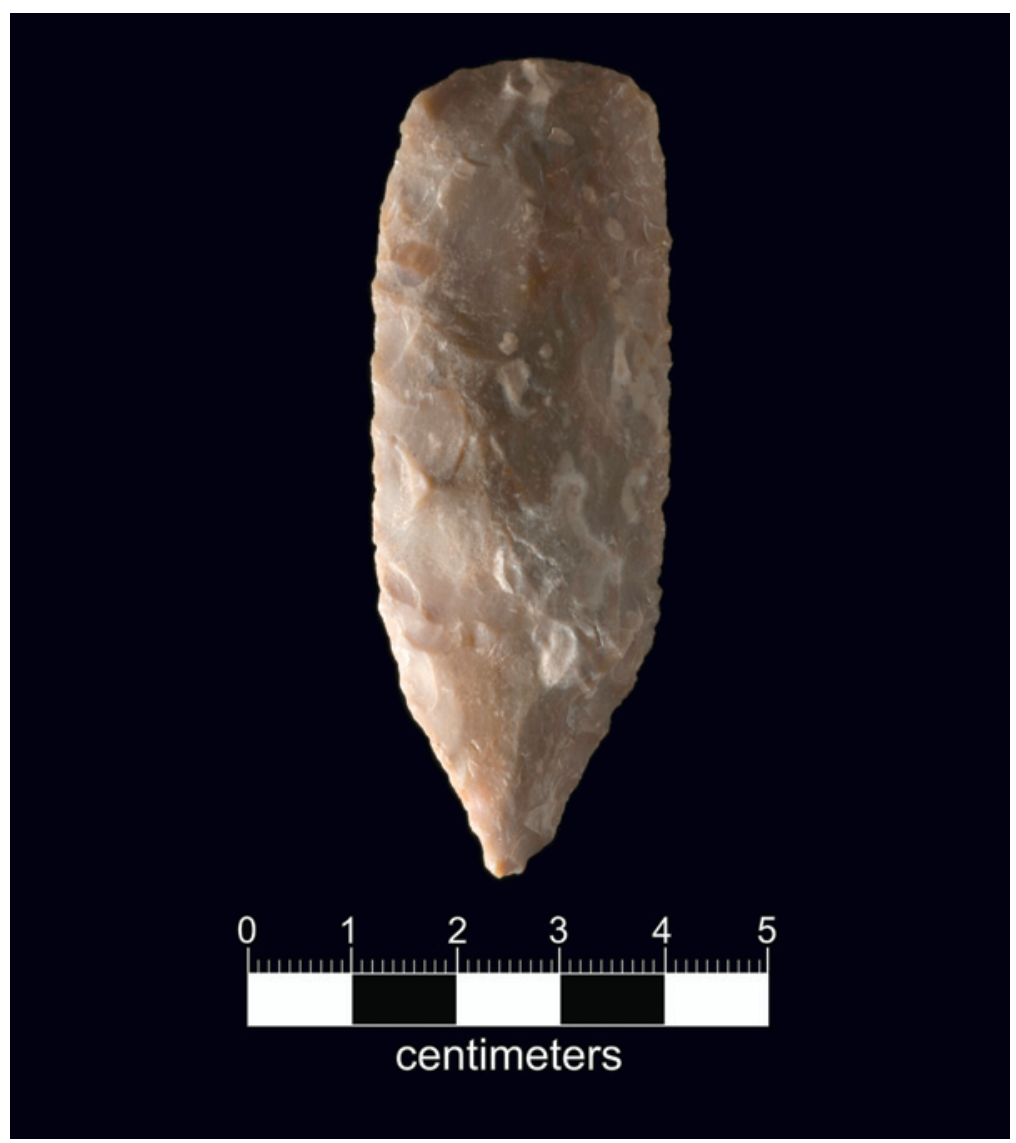

Figure 3-38. Multipurpose bifacial tool, Specimen No. 14-1.
These distinctive tools (Figure 3-39) were expediently, but often delicately, made from flakes, bifaces, or recycled projectile points. Shaft lengths may be as long as 66 mm (Specimen No. 232-1). Bit width varies from 8 to $13 \mathrm{~mm}$.

Large drills are frequently found in midden deposits of the Archaic period, but they are different from the small flake drills that are found in Toyah Phase assemblages (see Black and McGraw 1985:Figure 33). One function of large drills such as these, persuasively demonstrated by LaBudde (2008), is that they were used to drill a perforation at the distal end of an atlatl 


\section{Chapter 3}

spear shaft in order to insert the pointed or proximal end of the foreshaft. Large drills can be expected to be present in campsite components where tool manufacture and maintenance took place. Drills in the central Texas area could well have been used for working dart shaft sockets, but varying wear patterns indicate that additional uses involved drilling of shell and of stone (Turner et al. 2011:239).

\section{Beveled Knife (n = 1)}

Specimen No. 141-5 (Figure $3-40 \mathrm{~b})$ is the proximal end of a thin four-edged beveled knife. It has a slight bevel on both faces near the pointed end that adds to the characteristic twist of this type of knife. It was broken by a snap fracture. Four-edged beveled knives are diagnostic of the Toyah phase tool assemblage, and date from ca. A.D. 1300-1700 (Turner et al. 2011).

\section{Large End Scraper $(n=1)$}

Specimen No. 31-2 is an end scraper made on a large secondary cortex flake (Figure 3-40a). The bulb of percussion has been removed by several flakes taken from the ventral surface in order to thin the proximal end of the scraper, perhaps to facilitate hafting.

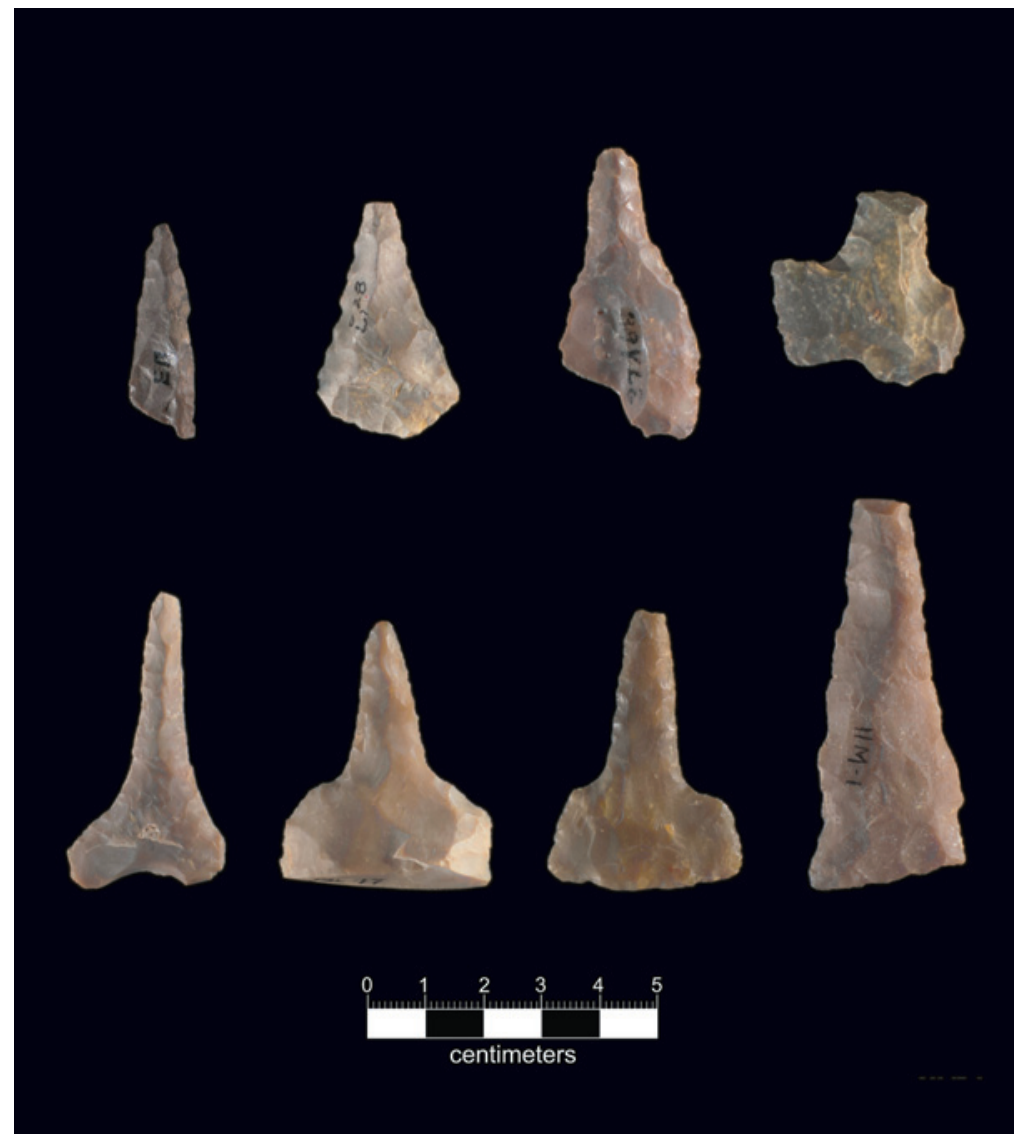

Figure 3-39. Large drills.

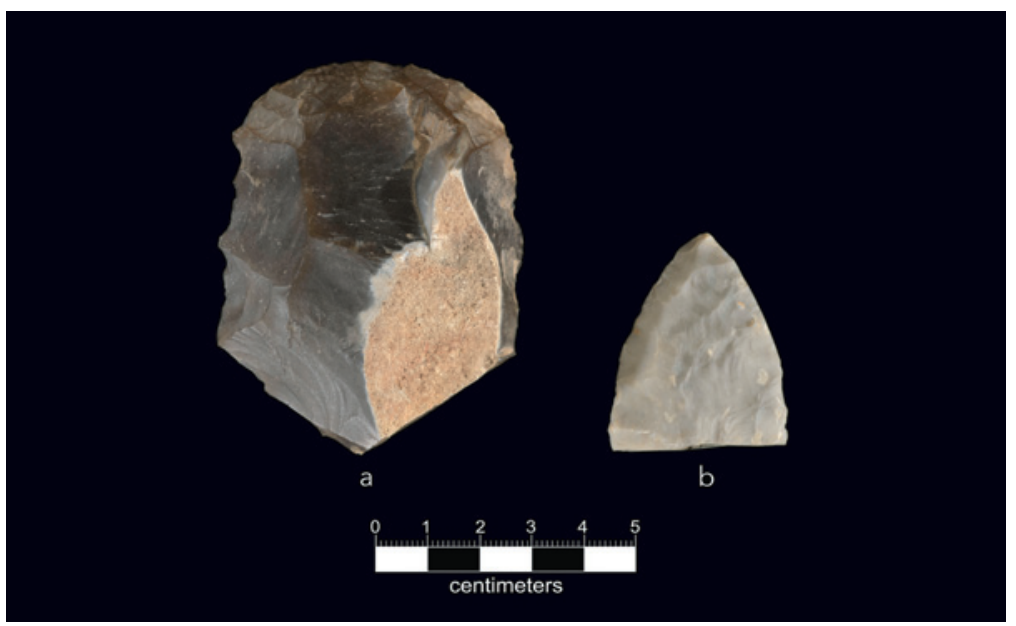

Figure 3-40. Large end scraper, Specimen No. 31-2 (a) and beveled knife fragment, Specimen No. 141-5 (b). 
Inasmuch as large end scrapers are often associated with intervals when bison were present in the landscape, this specimen could be associated either with the interval marked by Castroville and Montell points, or perhaps with the Toyah interval.

\section{Small End Scraper $(n=1)$}

This specimen appears to be a bifacially worked arrow point but has a distinctive beveled convex wider end that resembles an end scraper. Its size, however, probably precludes this function.

\section{Clear Fork Adzes $(\mathrm{n}=7)$}

Although the bit ends are missing on all but two specimens, each artifact in this group of Clear Fork bifaces exhibits the basic attributes of the tool type (Figure 3-41). We feel they functioned as adzes and were used as woodworking implements (Hudler 1997). Technologically they are relatively thick bifacial artifacts fashioned with a lenticular cross section that, when chipped unifacially at the wider end, creates a scoop-like bit. Lateral edges are dulled to facilitate hafting. Two are relatively complete (67-1 and 86-1),

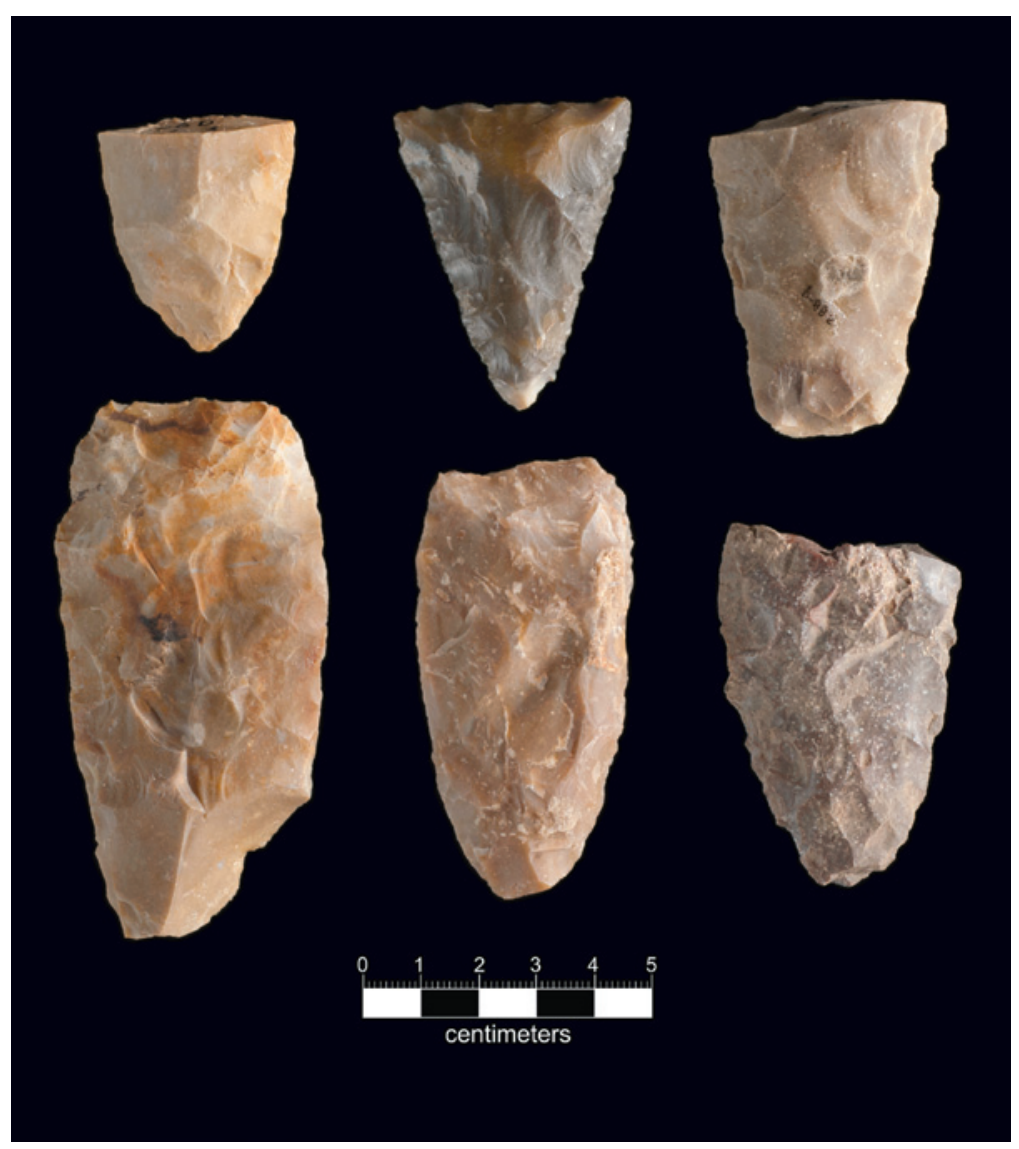
although the latter of the two has some damage on the proximal end that appears to be pick-struck. Four are proximal ends, three of which have bending snap fractures; one is a medial section also broken by snap fractures.

The bifacial Clear Fork adze is a diagnostic tool associated with Late Paleoindian (Early Archaic adzes are large, unifacial artifacts). Some of the earliest examples come from Baker Cave, at 9000 B.P. Dial (1998:520-535) provides a lengthy discussion about the chronological and temporal distribution of Clear Fork tools and the possibly related Figure 3-41. Clear Fork adzes. Brushy Creek Bifaces. 


\section{Adzes Made on Point Fragments $(n=2)$}

These tools are made on fragments of St. Mary's Hall points (Figure 3-42). Specimen No. 2921 is the proximal end of a St. Mary's Hall point that was rejuvenated into a small adze with the distinctive unifacially beveled bit. Specimen No. 259-2 is made on a medial fragment that exhibits the characteristic oblique-parallel flaking of the type. Interestingly, the rejuvenation into an adze bit was possibly done after the two-tone gray point fragment was slightly patinated, as a slightly darker gray interior can be seen at the bit. This evidence suggests the St. Mary's Hall point had been discarded for some time before it was recycled into an adze.

\section{Miscellaneous Adzes ( $n=8)$}

This group includes tools that have wider bit ends and that (1) are unifacial (Specimen Nos. 100-1 and 235-1 [see Figure 4-24, page 69]), or (2) have unifacially fashioned bit ends (Specimen Nos. 288-32, 131-1, and 150-1), or (3) have bifacially fashioned bit ends that display impact fracture. Specimen No. 202-2, for example, is a small oval biface that exhibits impact damage at the wider end; this end also has a slightly scooped appearance. Impact damage is also seen at the narrow end, suggesting that the tool may have been reworked from a projectile point fragment.

\section{Lunate Uniface $(n=1)$}

Specimen No. 34-1 is an unusual artifact, made from a large flake that is rounded on one end and constricted to a dull point at the opposite end (Figure 3-43). It is partly shaped by earlystage bifacial flaking. One later edge is convex; the opposite, slightly smoothed concave edge displays a steep bevel. Clearly, the working edge is the concave edge with an 80-degree angle.

A similar specimen was reported by Crawford (1965:Figure 10a) from the Granite Beach site in Burnet County. The function of this tool is unknown, but one possibility is that it was a beaming tool used to process the hides of large animals. 


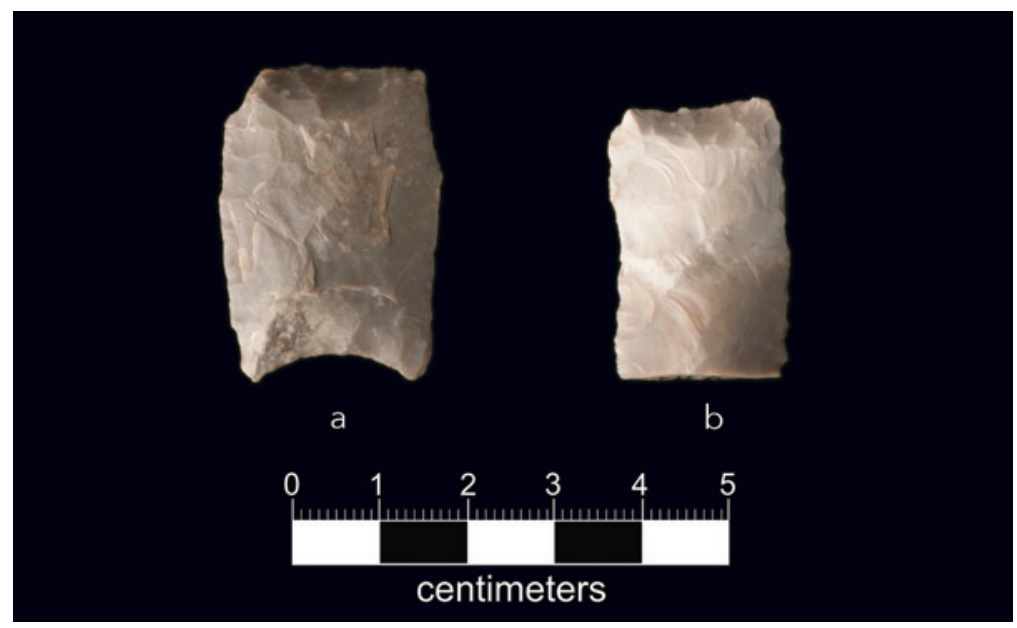

Figure 3-42. Adzes made on point fragments: (a) Specimen No. 292-1; (b) Specimen No. 259-2.

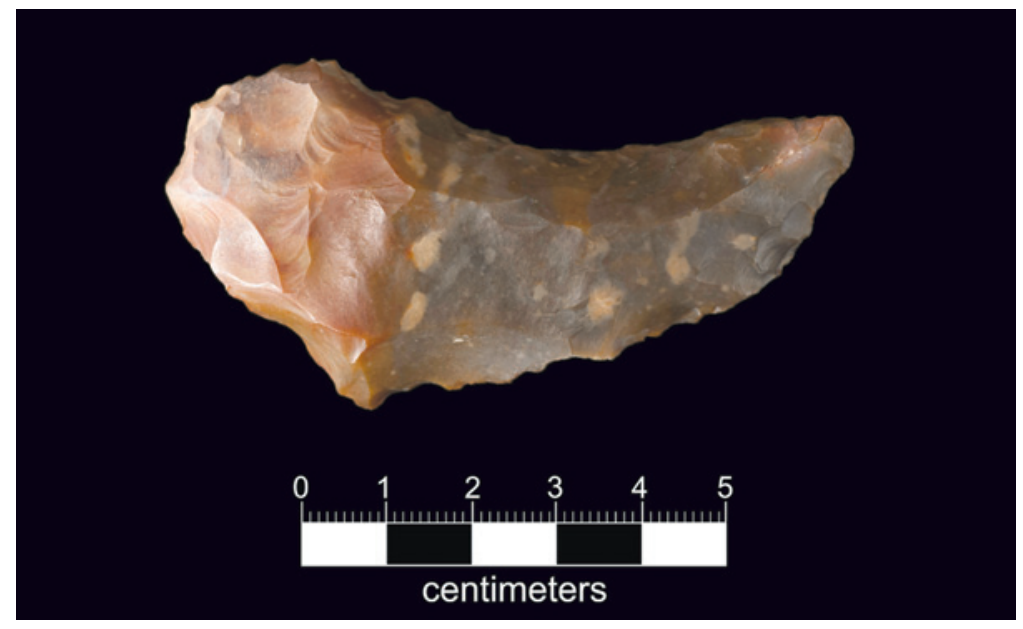

Figure 3-43. Lunate uniface, Specimen No. 34-1. 



\section{Chapter 4 \\ A Glance Through 13,500 Years}

Jon C. Lohse

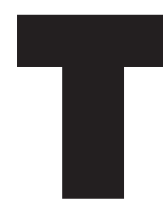

he importance of the Spring Lake site in New World prehistory is reflected through its artifacts, especially those from Shiner's underwater work of the 1970s and 1980s. The significance of the site, not generally recognized at the time the early studies were conducted, has gradually become apparent as continued research has revealed a seemingly unbroken record of human occupation beginning more than 13,000 years ago during Clovis times. This remarkable record continues through the historical period of Spanish exploration and into the twenty-first century.

Such a long record of human occupation at one place is very rare among known archaeological sites in Texas and even throughout the Americas. The thorough study of a site with deeply buried deposits typically requires many seasons of labor-intensive fieldwork and, because of constraints of time and resources, happens infrequently. Consequently, archaeologists have not yet developed a clear understanding about the role sites like these played in regional prehistoric cultural history.

The presence of fresh water and abundant environmental resources at Spring Lake, including fish, frogs and turtles, terrestrial mammals and many useful plant species, is undoubtedly part of the reason this site was occupied for so long. But the easy availability of these resources tells only part of the story. A defining characteristic of the earliest prehistoric occupants of the region was their residential mobility; these hunter-gatherer groups never established a sedentary way of life (Collins 1995). Spring Lake was always part of more extensive cultural systems of settlement, economy, social relationships and interaction, and subsistence, and its story can only be fully understood within these larger contexts. Even under Shiner's "base camp" or Takac's "home base" models (discussed in Chapter 2), both of which recognized the central role that Spring Lake would have played in these regional patterns, site 


\section{Chapter 4}

occupants would also have relied extensively on resources outside the local environment. At certain times of the year they would have occupied sites located elsewhere.

The nature of the relationships between the occupants of Spring Lake occupants and residents of other geographic areas is another little-understood aspect of the cultural history of these groups. For example, biological evidence, in the form of stable carbon and nitrogen isotopes from a burial from the Fish Ponds site, just downhill from Old Main on the University's main campus, shows that at least some of the area residents came from outside the local area. Dietary reconstructions of a woman, who was 25-45 years old when she was buried more than 500 years ago, showed that she had enjoyed a nitrogen-rich diet consistent with coastal environments. This evidence suggests that she had lived much of her life on or near the Texas coast before coming to Spring Lake shortly before she died (Munoz et al. 2011; Stull and Hamilton 2011). Our understanding of Spring Lake within a larger geographic context will improve as research continues on all of the various kinds of sites in the surrounding region, extending at least as far away as the shores of the Gulf of Mexico.

Given the long occupation of Spring Lake, one of its many research potentials is that it allows archaeologists to study the passage of time in an archaeological context. The term "archaeological context" is somewhat misleading here because so much of the record of occupation of a site depends on environmental and geologic factors. For example, sediments encasing layer upon layer of time-ordered remains (older at the bottom and progressively younger toward the top) may have accumulated without interruption through time, or some of the evidence-containing sediments may have been washed away by erosion. Moreover, much of the significance of the Spring Lake site involves its historical nature, as will be discussed below. Nevertheless, the systematic documentation of approximately 13,500 years of occupation, together with the description and interpretation of this record in terms of continuity, constitutes a major contribution to Texas and North American archaeology

\section{How Archaeologists Tell Time}

In their use of different techniques to record, verify, or calibrate the passage of time, archaeologists recognize subtle but meaningful differences in terminology as well as approaches. In the research at Spring Lake, for example, archeologists observe significant distinctions between ages and dates and between chronologies and single dates.

\section{Absolute dates}

Absolute or chronometric dates are expressions of a computed numerical age cited as a certain number of years from a common reference point. Using the contemporary Gregorian calendar as an example, absolute dates are given as a specific number of years B.C. or A.D. (before Christ, Anno Domini) or B.C.E. and C.E. ("before common era," or sometimes just "common era"). In this system, time is measured in solar years. . 
Radiocarbon dates, based on the most commonly used method of absolute dating in archaeology, are often conveyed as some number of radiocarbon years before present (B.P.). In radiocarbon dating, "present" is arbitrarily defined as A.D. 1950, the year in which calibration curves for radiocarbon dating were first established. Although radiocarbon years are not the same as calendar years, they can be converted or "calibrated" to calendar years, with results expressed in the format of cal B.C. or cal A.D. (or as cal B.C.E or cal C.E.), or sometimes as cal B.P. When calibrated, a resultant date is expressed as a span of years that represents a statistical probability of being accurate - the larger the span, the greater the probability that the dated event occurred within that span. Although dates obtained through radiocarbon dating are often referred to as absolute dates, it is important to understand that even the best radiocarbon dates can provide only a general idea about when an event took place.

\section{Relative ages}

In contrast to absolute dates, relative ages indicate the temporal order of certain objects or events relative to other objects or events. Relative ages tell researchers which events are older and which ones are younger in a sequence. Technically, inasmuch as relative ages do not indicate the computed age of an artifact or deposit in absolute terms, these are not actual dates. This distinction illustrates the major difference between "age" and "date." The former is used in general terms to describe the antiquity, in either absolute or relative terms, of an object, whereas the latter is used more precisely to convey in a given unit of time how old something is. Work at Spring Lake, starting in the late 1970s and continuing up until the present, has amassed a considerable radiocarbon record that provides absolute dates for large segments of the cultural record. However, many deposits, particularly the older ones, still remain to be directly dated.

Whereas a single date may be helpful in developing an idea about how old a site or deposit is, a more fundamental archaeological concern is the construction of a chronology, or a sequence of dated events, deposits, or layers. One of the most significant features of the Spring Lake record is the apparently unbroken chronology of occupation from the earliest of Clovis times up to and beyond the arrival of Spanish explorers in the region. To our knowledge, no comparable degree of continuity has yet been documented at a single site anywhere else in the New World.

\section{Cross-Dating}

Chronology-building has long been one of the guiding objectives of research in Central Texas (Collins 2004; Houk et al. 2009; Lohse et al. 2014). Defining cultural behaviors for any time interval and geographic area allows researchers to recognize when certain adaptations occurred, what material evidence these adaptations generated, and how they changed through time. Without temporal controls, all subsequent analyses are left unanchored or floating in time and are devoid of much of their interpretive significance. Aside from absolute dates, which 


\section{Chapter 4}

may be cost-prohibitive to produce in some projects, one way to provide chronological control to a sequence is by the use of cross-dating. Through the recognition of stylistically distinctive or diagnostic projectile points, cross-dating provides the basis of most chronology-building in Texas archaeology. A fine discussion of the approaches to and value of cross-dating and of typological analyses is presented in Chapter 3.

The simple concept behind cross-dating is that a particular artifact type known to date to a certain time period at one site will date to approximately the same period elsewhere. One strength of this technique is that it is relatively inexpensive, simply requiring a familiarity with artifact types and styles from a region in question. Another advantage, at least in the case of projectile points and other diagnostic tool forms that occur in large numbers in Central Texas, is the easy application of cross-dating to hundreds or even thousands of artifacts from a site, in many cases regardless of contextual preservation or quality of association.

Cross-dating, however, also has significant weaknesses. Predicated on the concept of archaeological types (see discussion, Chapter 3), the method assumes that certain types (1) are well defined where they were initially recognized, (2) are securely dated, (3) do not include unrecognized stylistic or technological variations warranting alternative typological designations, and (4) are coeval wherever they occur. Frequently one or more of these conditions is not sufficiently satisfied to the degree necessary for a certain type to be used in the cross-dating of deposits elsewhere. The fullest range of technological and stylistic variation is almost never defined when a type is first recognized. Clarification and refinement of descriptions is an ongoing process, contributing to the gradual growth of archaeological knowledge. Here, too, the present analysis of Shiner's collection is an important contribution to regional and statewide research.

As previously noted, at the time they were first defined, many types found at Spring Lake and in Central Texas were not well dated, and, many years later, subsequent research may still not have produced suites of absolute dates sufficient for anchoring those types in real time. However, differences in the chronological placement of types from one site to the next, even if the difference is only a few dozen years, may have crucial implications in the development of an archaeological understanding of acculturation processes, the documenting of shifts in subsistence strategies, or the identification of changes in site occupation through time. In general terms, cross-dating rarely provides the temporal resolution necessary to observe chronological changes on the order of a hundred years or less, which in prehistoric times may have encompassed as many as four human generations. Ideally, cultural chronologies should rely on all available and appropriate dating techniques, and sequences built mainly on crossdating should be bolstered by absolute dates from secure, reliable contexts.

As Shafer and Hester note in Chapter 3, more than 60 years of work on the definition of time-diagnostic types is one of the main strengths of archaeological research in Texas. This is certainly the case in Central Texas, where numerous researchers have constructed and refined 
Table 4-1. Cultural chronology for Central Texas.

All time periods and all diagnostic types are present at Spring Lake (from Lohse et al. 2014).

\begin{tabular}{|c|c|c|c|}
\hline $\begin{array}{l}\text { Geological } \\
\text { Epoch }\end{array}$ & $\begin{array}{l}\text { Archaeological } \\
\text { Period }\end{array}$ & $\begin{array}{l}\text { Selected Diagnostic } \\
\text { Point Types }\end{array}$ & $\begin{array}{c}\text { Age, in } \\
\text { Calendar Years } \\
\text { Before Present }\end{array}$ \\
\hline \multirow{10}{*}{ 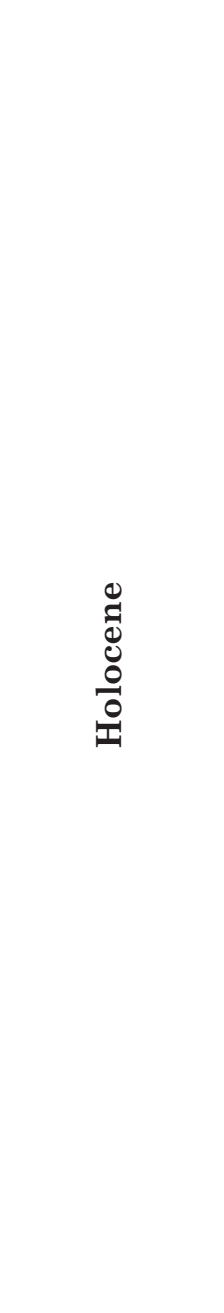 } & Historical & & $\begin{array}{c}\text { In Central Texas, } \\
\text { Historical period } \\
\text { begins } \\
\text { ca. A.D. } 1550\end{array}$ \\
\hline & Late Prehistoric/Toyah & Perdiz & $650-<300$ \\
\hline & $\begin{array}{c}\text { Transitional Archaic/ } \\
\text { Austin }\end{array}$ & Darl, Scallorn, Edwards & $1270-650$ \\
\hline & Late Archaic III & Ensor, Fairland, Frio, Ellis & $2150-1270$ \\
\hline & Late Archaic II & Montell, Castroville, Marcos & $3100-2150$ \\
\hline & Late Archaic I & $\begin{array}{l}\text { Bulverde, Pedernales, } \\
\text { Marshall, Lange, Williams }\end{array}$ & $4200 / 4100-3100$ \\
\hline & Middle Archaic & $\begin{array}{c}\text { Early Triangular (Baird, } \\
\text { Taylor), } \\
\text { Nolan, Travis }\end{array}$ & $5750-4200 / 4100$ \\
\hline & Early Archaic III & $\begin{array}{c}\text { Calf Creek (Bell, Andice), } \\
\text { Martindale, Bandy }\end{array}$ & $6000(?)-5750$ \\
\hline & Early Archaic II & Uvalde, Gower, Hoxie, Jetta & $8000-6300(?)$ \\
\hline & Early Archaic I & Angostura & $8800-8000$ \\
\hline \multirow{2}{*}{$\begin{array}{l}0 \\
\stackrel{0}{0} \\
0 \\
0 \\
\frac{0.0}{0} \\
\frac{0}{a}\end{array}$} & Late Paleoindian & Golondrina, St. Mary's Hall & $10,200-8800$ \\
\hline & Early Paleoindian & Clovis, Folsom & $13,500-10,200$ \\
\hline
\end{tabular}




\section{Chapter 4}

regional cultural sequences based on the definition and dating of artifact types and their associated remains. Significant examples have been provided by Elton Prewitt (1981, 1983), Michael Collins (1995, 2004), and Ellen Sue Turner and her colleagues (Turner et al. 2011). Using these models as a foundation, recent work at Spring Lake and elsewhere has been used to construct a detailed chronology that defines all the major recognized time periods in the region (Table 4-1). Some variations to this sequence can be expected, such as with associated dates (especially for older periods), and some researchers may choose to recognize additional subperiods. Nevertheless, in an ideal setting (e.g., freshwater springs, abundant associated resources, alluvial deposits that were not completely eroded during the climatic perturbations of the middle Holocene), archaeological research in Central Texas can expect to encounter this sequence.

\section{3,500 Years at Spring Lake}

Although the Spring Lake chronology is based largely on cross-dating of time-diagnostic artifact styles, most of which are defined and discussed in Chapter 3, years of archaeological research have produced many radiocarbon dates ( $\mathrm{n}=96$ at the time of this writing), which can now be used to help clarify certain time periods and deposits across the site. As Figure 4-1 illustrates, the continuous radiocarbon record actually extends only to approximately 8000 years ago, reflecting the limitations so far on controlled excavations at this site. Presumably, future work that reaches lower depths will continue to fill gaps in earlier time periods.

Nevertheless, through the use of cross-dating, archaeologists know that people were present not only during periods well represented in the radiocarbon record, but during earlier periods as well.

\section{Archaeological Time Divisions}

In terms of material culture (the physical remains left behind by millennia of occupation), what do 13,500 years look like? Archaeologists divide human presence in the Americas into two very general time periods, called the Prehistoric and the Historical eras. The Prehistoric covers by far the greatest part of this time span, from the initial appearance of people in the study region, well over 13,500 years ago, all the way up to the entry of Spanish explorers in the early 1500s. Archaeologists divide the very long Prehistoric era into the Paleoindian, Archaic, and Late Prehistoric periods. As presently understood, the Paleoindian period began at Spring Lake approximately 13,500 calendar years ago, although evidence from elsewhere (Collins and Bradley 2008; Waters et al. 2011) suggests people were present in Central Texas 1000 years or more before this date. The beginning of the Historical era, sometimes referred to archaeologically as the Protohistoric period, specifically covers the time of Spanish missionization. From a scientific perspective, the primary difference between Prehistoric and Historic periods is the occasional availability of written records that help archaeologists reconstruct historical events and interpret material remains. Native Americans remained 


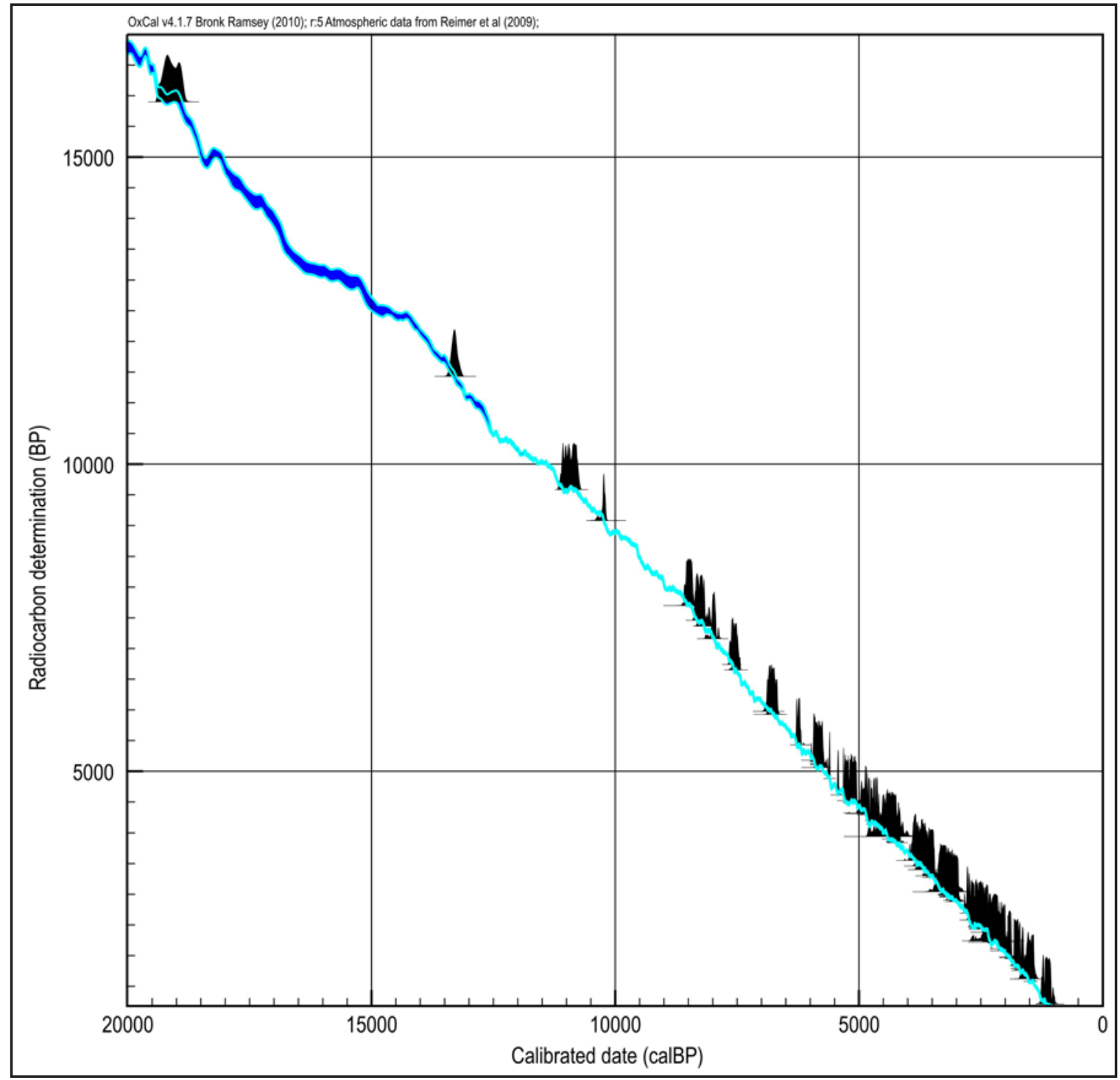

Figure 4-1. Calibrated results of 96 radiocarbon dates available from Spring Lake. Although the oldest dates are not from cultural contexts, they do indicate the presence of very old sediments potentially capable of containing archaeological materials. The decreasing frequency of older dates reflects the fact that controlled excavations at this site have seldom reached levels predating approximately 8000 years ago.

numerous in the region for at least 200 years after Europeans first arrived, and even today San Marcos is a center of activity for indigenous organizations, celebrations, and advocacy groups. Historical records chronicle the use of the springs by Spanish and Native American groups in the seventeenth, eighteenth, and nineteenth centuries, and as early as the mid-nineteenth century by Edward Burleson and other Anglo settlers. In addition to their public and scientific value, today the springs are viewed by some indigenous groups as sacred. Below is a brief, summarized history of some of the material culture sequence from Spring Lake. 


\section{Chapter 4}

\section{Paleoindian}

The Paleoindian period marks the time of the earliest human occupation of North America, lasting until approximately 8800 B.P. Generally, Paleoindian people, especially Early Paleoindians, were long thought to be nomadic wanderers who used stone-tipped spears to hunt large game animals such as mammoth, mastodon, bison, camel, and horse (Black 1989), ranging broadly and randomly wherever their prey led them. However, some large Paleoindian sites, such as the Gault site in Bell County, contain evidence of long-term, serial reoccupation, suggesting that Paleoindian settlement models also need to account for large, central place-type camps. Recent research has shown that, in addition to hunting large animals, Paleoindians also utilized a wide variety of plants and numerous smaller animals, including raccoons, badgers, mice, alligators, turtles and tortoises (Black 1989; Collins and Brown 2000; Hester 1983; Lemke and Timperley 2008). Large Pleistocene animal remains, including horse, mammoth, and perhaps bison, have been reported from Shiner's work at Spring Lake. However, fine-recovery excavation methods necessary to the recovery of evidence of smaller animals have not yet been employed here.

Whereas Clovis points are associated both with kill sites of large mammals and with a broad-spectrum diet linked to encampments such as Gault, Folsom points are more closely associated with specialized bison hunting across extensive areas of the Great Plains (e.g., Meltzer 2006). Folsom groups were highly mobile over large expanses, and many sites suggest a high degree of specialization in hunting bison. Most Folsom sites occur as surface scatters, but deeply buried deposits have also been discovered. Sites containing Clovis and Folsom points occur throughout Texas (Bousman et al. 2004). Recent reevaluations of Early Paleoindian evidence suggest that Folsom may have stood out in terms of Paleoindian-like traits (high mobility, specialized big game hunting) while Clovis peoples pursued a more generalized, Archaic-like lifestyle (described below).

Diagnostic Early Paleoindian point types include Clovis, Folsom, and Midland. Both Clovis (Figure 4-2, Figure 4-3, Figure 4-4) and Folsom (Figure 4-5, Figure 4-6) are present at Spring Lake, albeit in small numbers. To date, no contexts from Early Paleoindian times have been identified in controlled excavations. Nevertheless, based on the presence of these points at $41 \mathrm{HY} 147$, remains from these earliest of time periods are known to be located somewhere in the vicinity, perhaps deeply buried beneath many feet of sediment.

Early Paleoindian point types are followed by numerous Late Paleoindian types, including Golondrina, St. Mary's Hall, Barber, Scottsbluff, and others. The diversification of distinctive styles at this time implies population growth and expansion, as sparsely occupied areas of the continental landscape became more densely inhabited. Spring Lake is particularly notable for the many St. Mary's Hall points found here (Figure 4-7, Figure 4-8, Figure 4-9, Figure 4-10, Figure 4-11). In Chapter 3, Shafer and Hester note that perhaps only one other site, the Wilson County Sand Pit, has produced more St. Mary's Hall points than Spring Lake. Other 


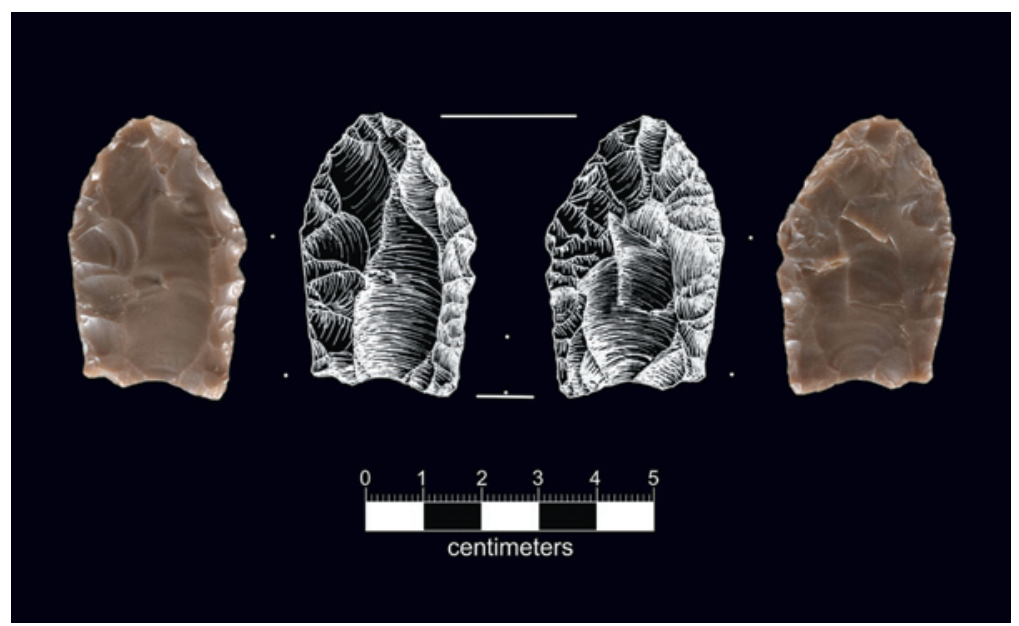

Figure 4-2. Clovis point, Specimen No. 310-1.

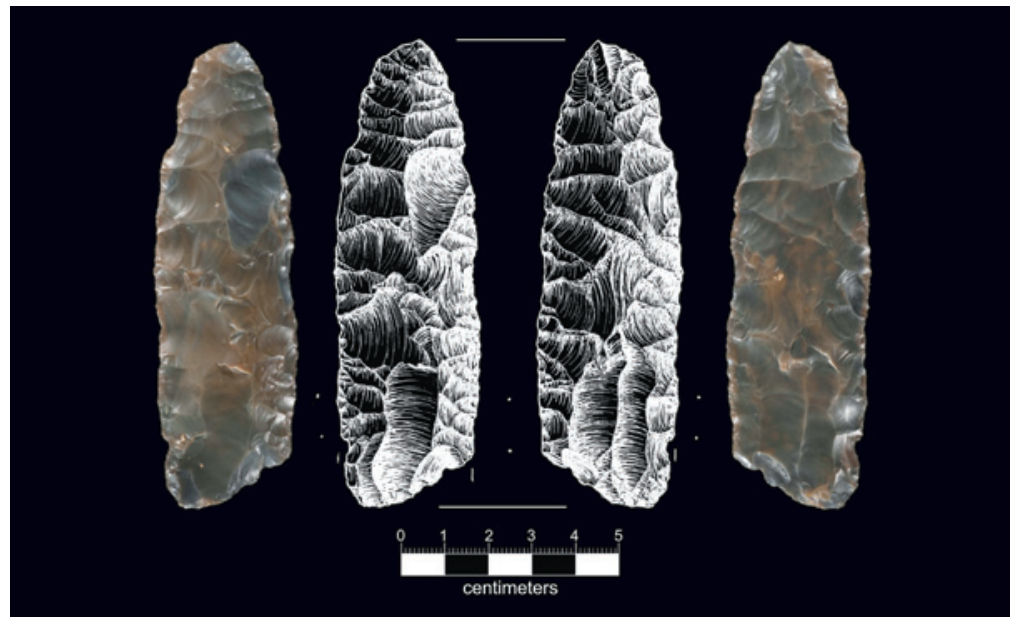

Figure 4-3. Clovis point, Specimen No. 310-2.

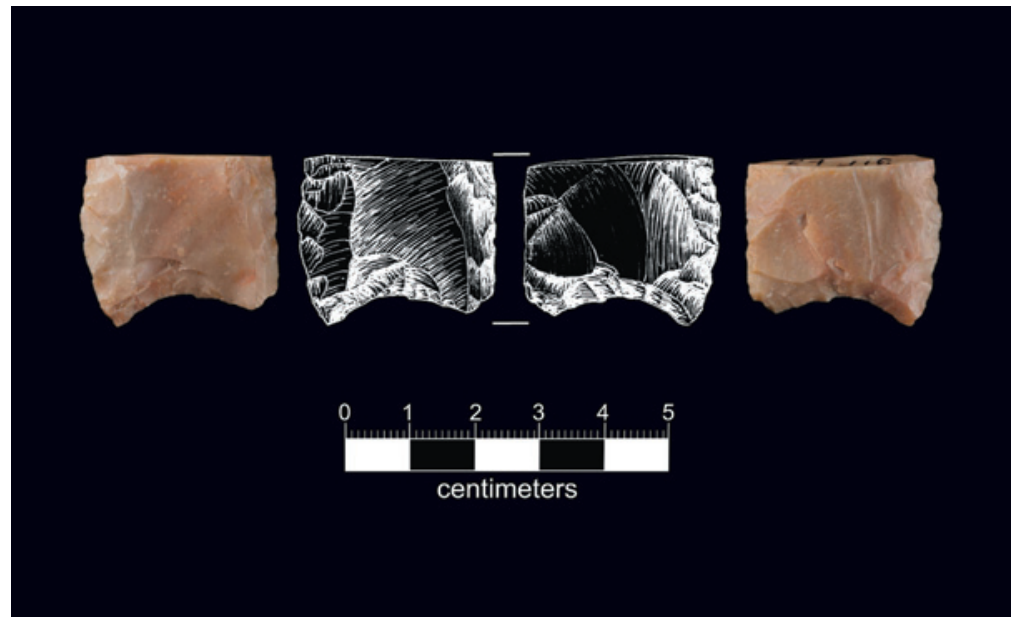

Figure 4-4. Clovis base, Specimen No. 77-2.
Late Paleoindian types

from Spring Lake include Golondrina (Figure 4-12, Figure 4-13), Angostura (Figure 4-14, Figure 4-15, Figure 4-16), San Patrice (Figure 4-17), and Wilson (Figure 4-18, Figure 4-19, Figure 4-20). Angostura points have recently been dated at the very end of this sequence, and extending slightly into the following Early Archaic period, thereby marking the end of the gradual transition out of Paleoindian lifeways.

Archaeological evidence indicates that large Pleistocene animals, with the exception of ancient bison (Bison antiquus), were extinct before 10,000 years ago. Hunters began concentrating instead on deer, antelope, and other game (Bousman et al. 2002, 2004). Reduced mobility is implied by the concentration of extensive deposits in some sites (including Spring Lake), and also by the diversification of point styles. This behavioral and technological shift accompanied a relatively sudden warming of climate at the end of the Pleistocene and beginning of the ensuing Holocene geologic epoch at 
approximately 11,000 years ago. Immediately following this rapid transition, numerous cultural groups may have lived in Central Texas, as is suggested by the many different styles of artifacts. Also as a result of climate change, diets were transformed as habitats became more diverse.

Technological responses to these kinds of changes are noted in toolkits that date to this period. A wider array of implements associated with cutting plants and working wood, including adzes fashioned on reworked St. Mary's Hall points (Figure 4-21), shows a little of what this transition looks like at Spring Lake. Collectively, these changes signal a new period in prehistoric chronologies, one that archaeologists refer to as the Archaic.

\section{Archaic}

Using data from numerous sites across North America, archaeologists define the Archaic on the basis of several indicators.

Subsistence patterns became heavily reliant on plant foods, as reflected by the appearance of earth ovens and grinding

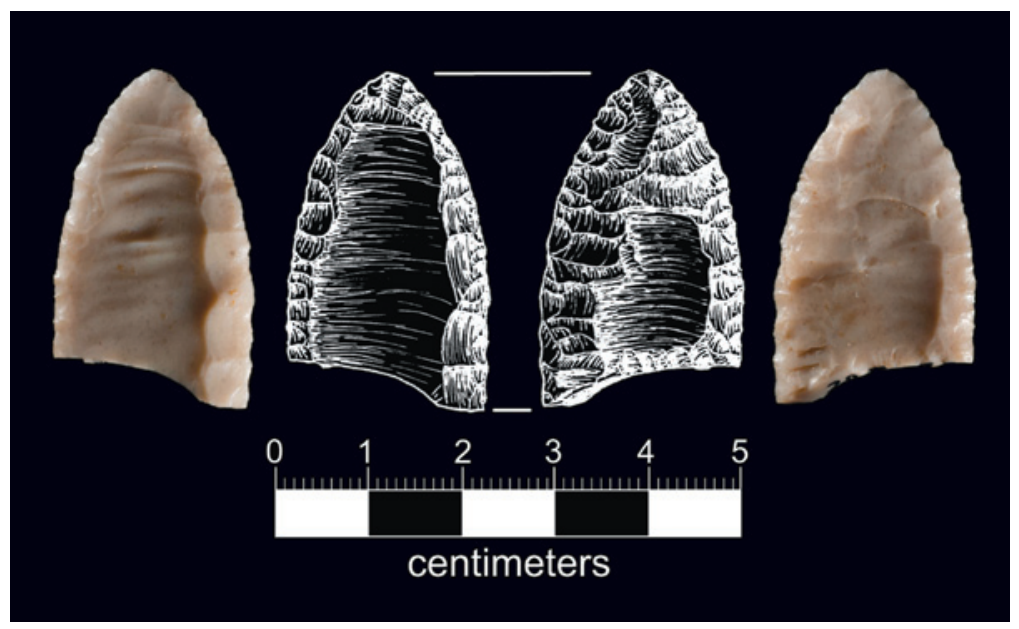

Figure 4-5. Folsom point, Specimen No. 119-2

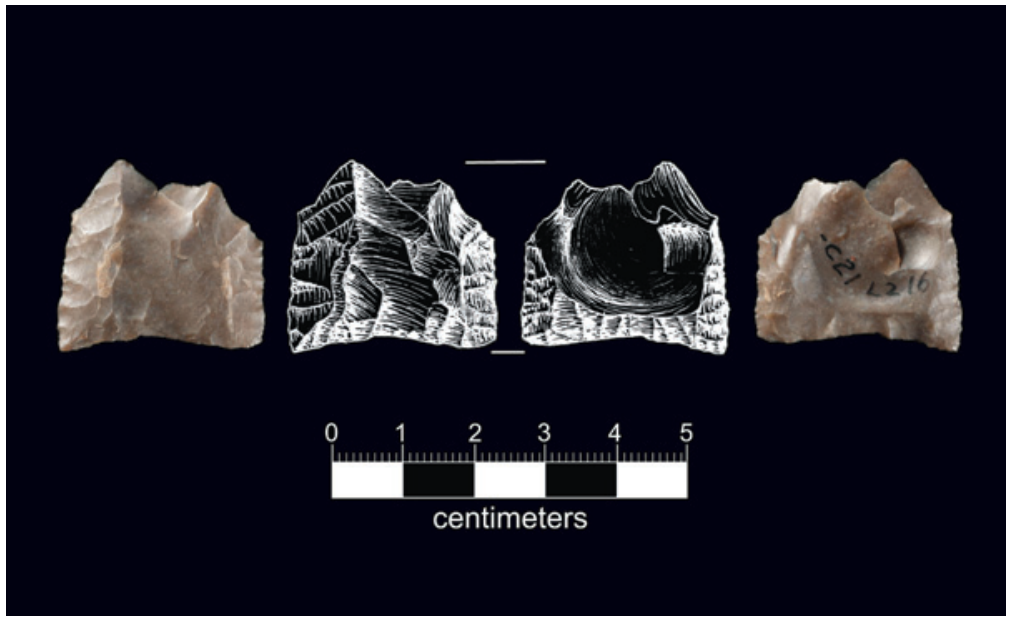

Figure 4-6. Possible Folsom base, Specimen No. 201-3.

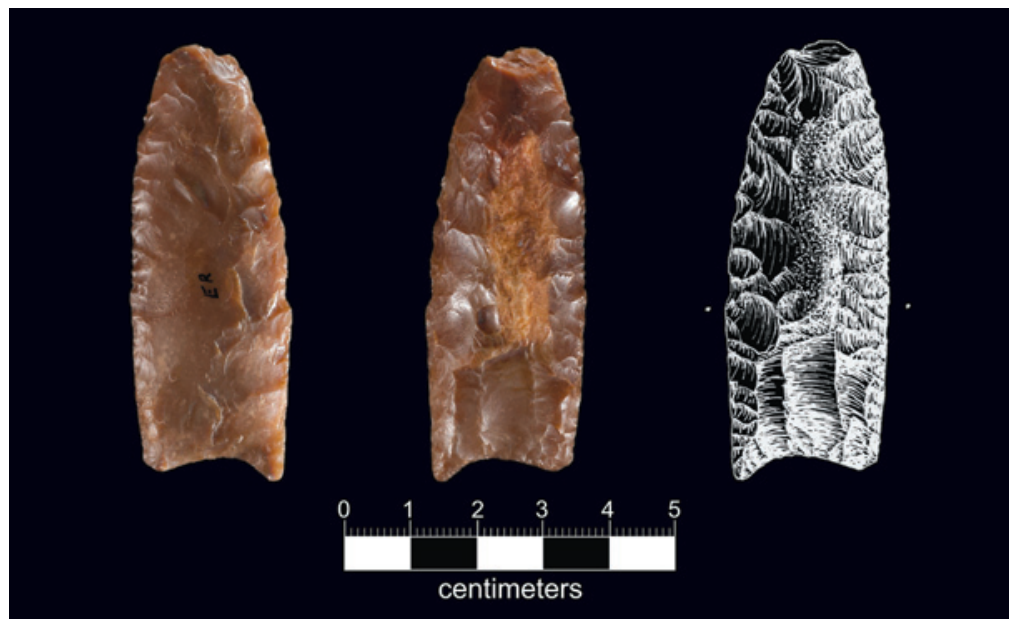

Figure 4-7. St. Mary's Hall point, Specimen No. 288-59. 


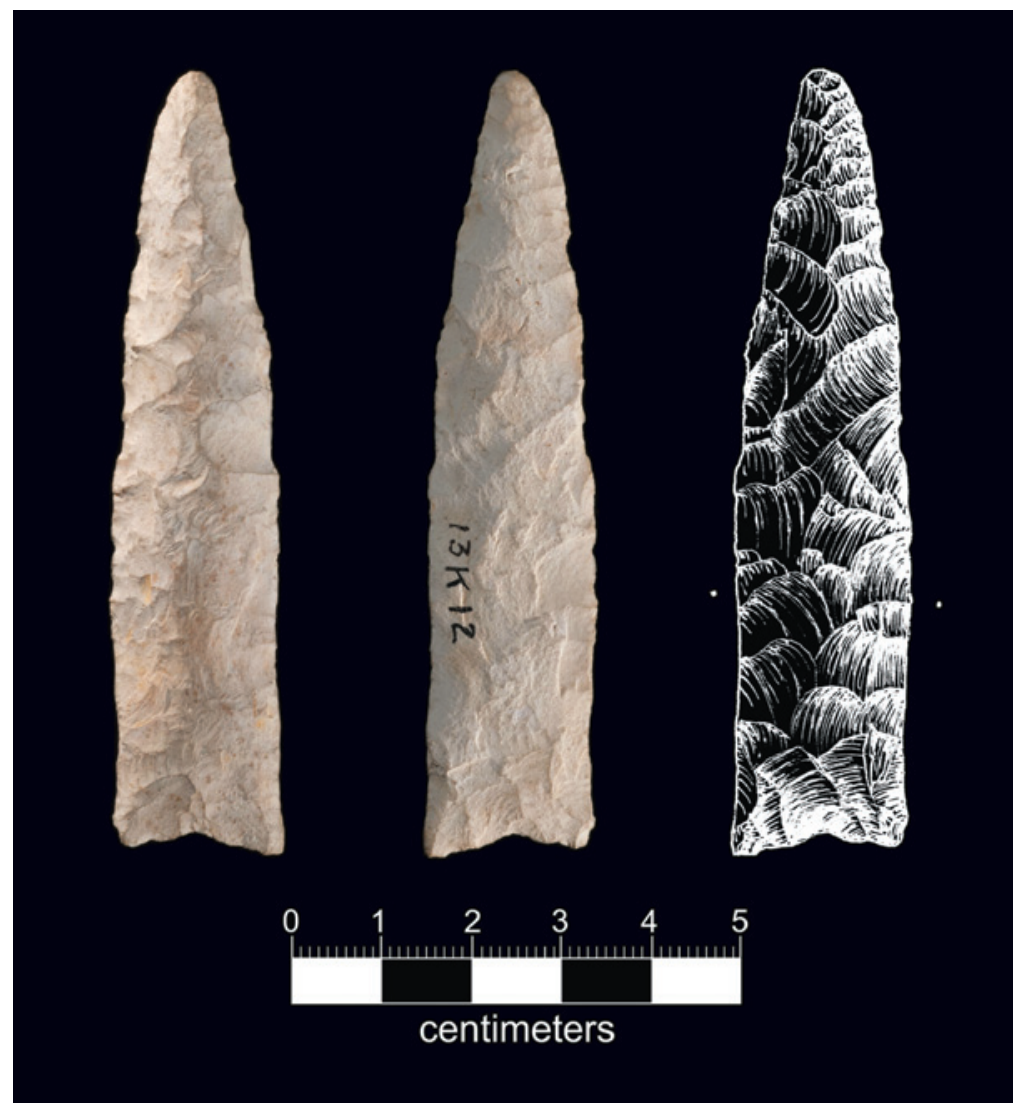

Figure 4-8. St. Mary's Hall point, Specimen No. 296-1.

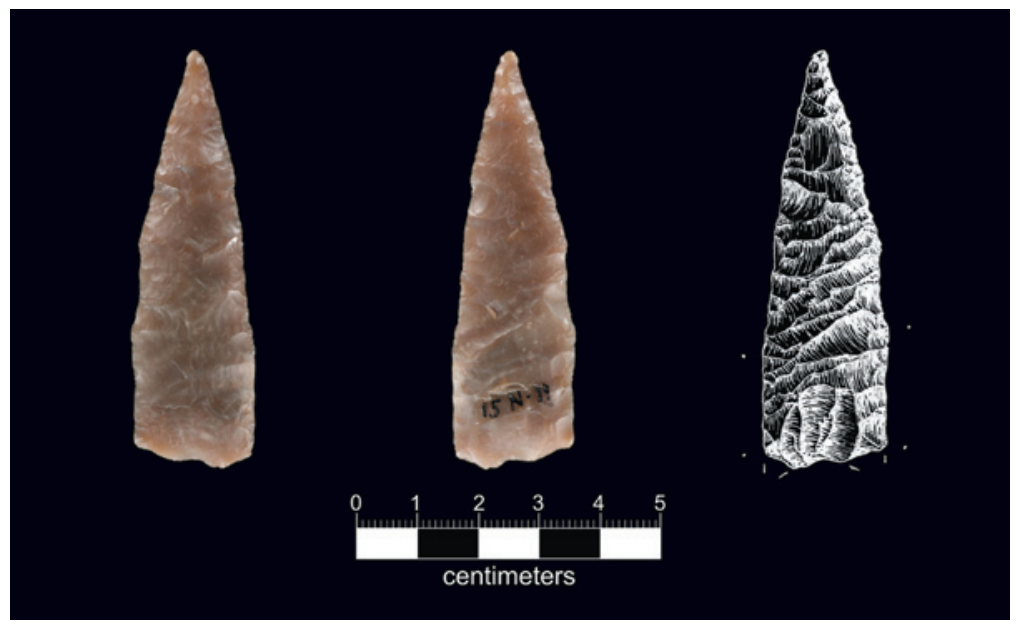

Figure 4-9. St. Mary's Hall point, Specimen No. 253-2. stones for processing nuts and seeds (Thoms 2008).

New cooking technologies involved the use of stones for their heat-retaining properties. Wood- and plantworking implements became stylistically formalized for perhaps the first time; archaeologists call some of these tools Clear Fork adzes (Figure 4-22, Figure 4-23). Other, non-standardized tool forms show multiple uses, such as for cutting, scraping, and perhaps use as an awl or possibly a drill. Unlike anything noted in the earlier period, regionalized Archaic traditions are established. One pattern that developed near the beginning of this period was the ritualized burial of the dead. Cemeteries were established in some locations in Texas by as early as 7500 years ago and even earlier elsewhere in North America.

Dating from as early as ca. 8800 years ago until ca. 650 years ago, the long Archaic period is divided into three parts: Early, Middle, and Late (Weir 1976). Traditionally, scholars have defined the end of the Archaic period by the appearance of bow and arrow technology, around 1200 years ago. However, recent research by CAS (Lohse et al. 2014) indicates that this shift, though significant, was relatively minor compared to evidence for strong cultural continuity 


\section{Chapter 4}

that lasted until ca. 650 years ago. As a result, we describe the Archaic as lasting until almost exactly A.D. 1300 thereby limiting the ensuing Late Prehistoric period to a narrow interval from ca. A.D. 1300 to the early 1500 s.

\section{Early Archaic}

As previously noted, the beginning of the Holocene was marked by a significant climate change associated with the extinction of megafauna, an environmental change which in turn triggered behavioral changes in land use and technological strategies. Specifically, groups began to focus more intensively on the exploitation of local resources such as deer, fish, and plant bulbs. This dietary change is evidenced by an increase in the number of ground stone artifacts, the presence of middens (accumulations of burned and fire-cracked-rock), and the appearance of woodworking tools such as Clear Fork adzes, Guadalupe bifaces, and other miscellaneous, nonstandardized adzes (Figure

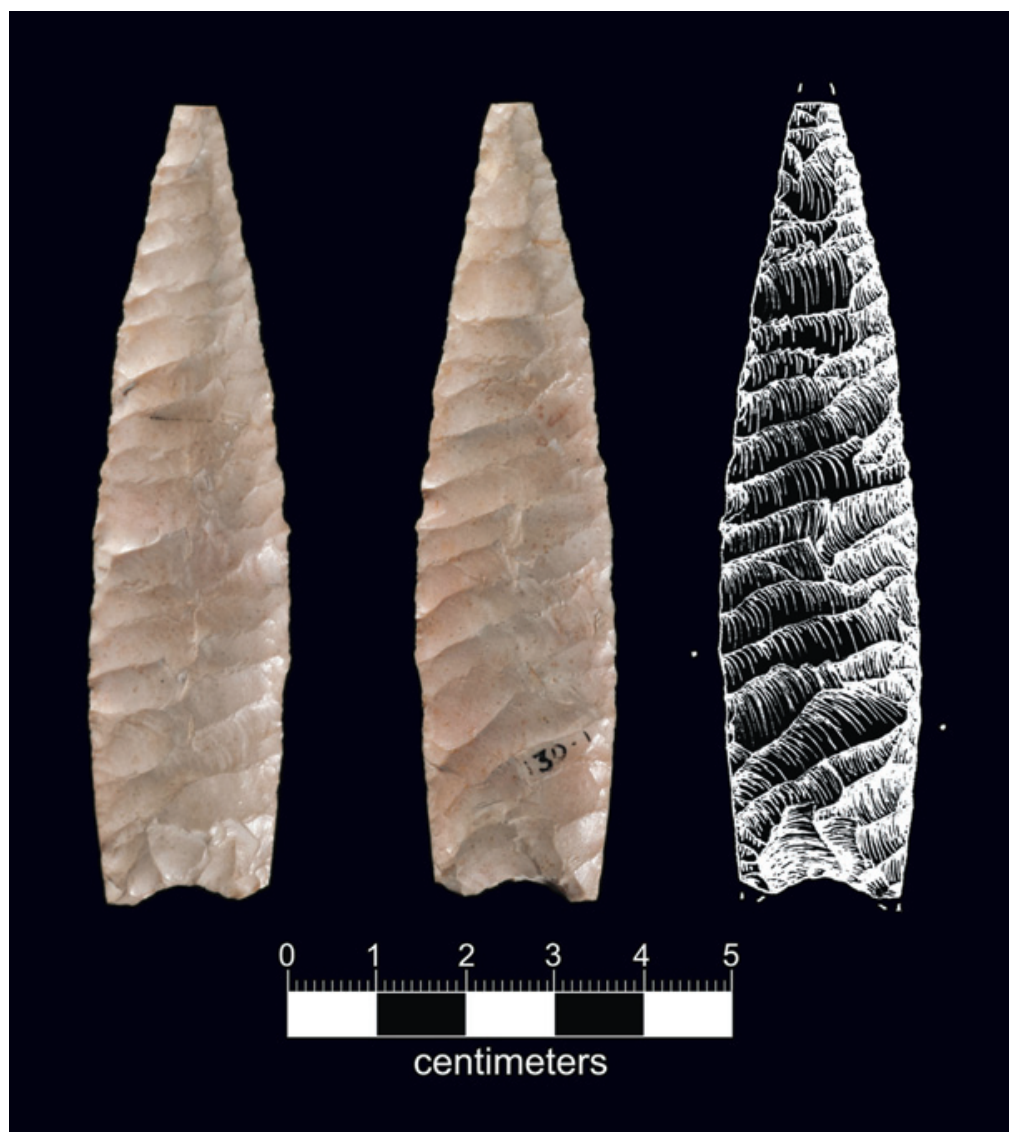

Figure 4-10. St. Mary's Hall point, Specimen No. 293-1.

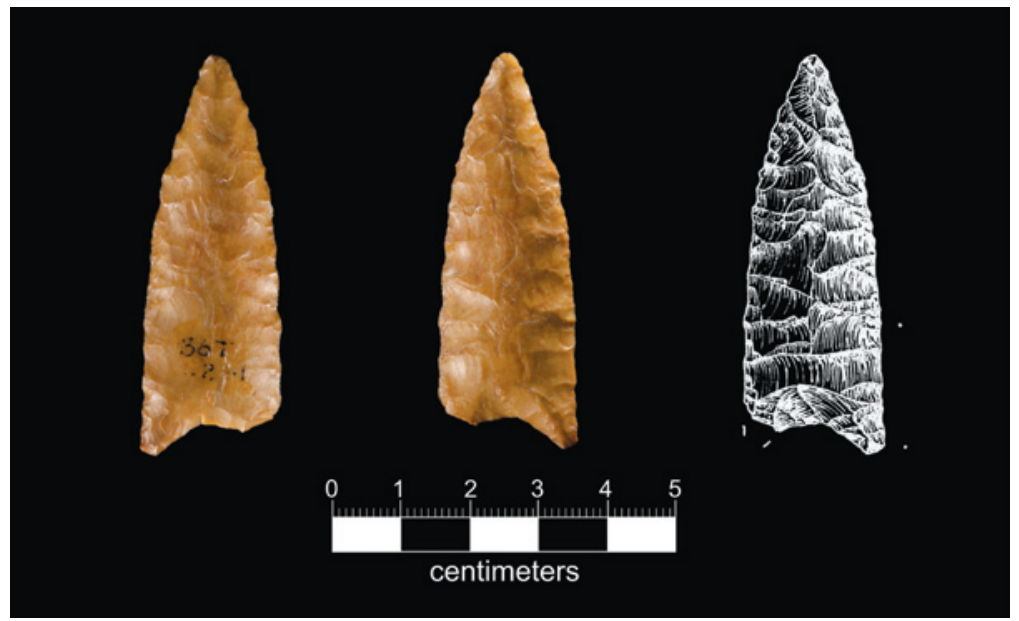

Figure 4-11. St. Mary's Hall point, Specimen No. 265-1. 4-24) (Turner and Hester

1993:246-256). Additional evidence for the diversification of toolkits for meeting general needs is in the form of long, well-fashioned drills made on broken and reworked bifaces (Figure 4-25). 


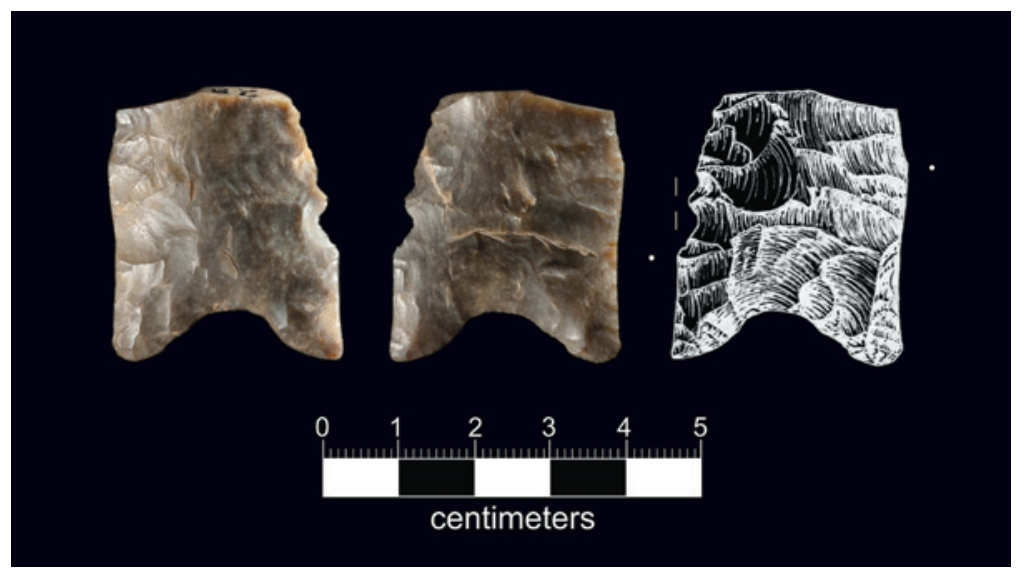

Figure 4-12. Golondrina point, Specimen No. 309-14.

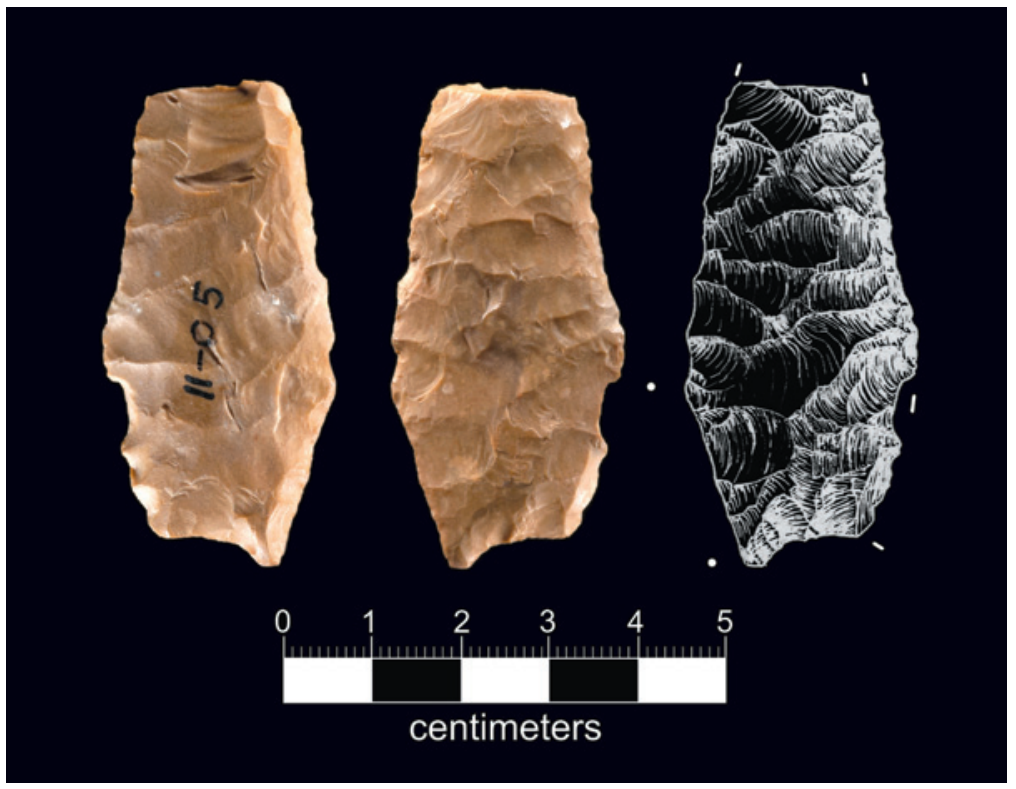

Figure 4-13. Golondrina point, Specimen No. 310-7.

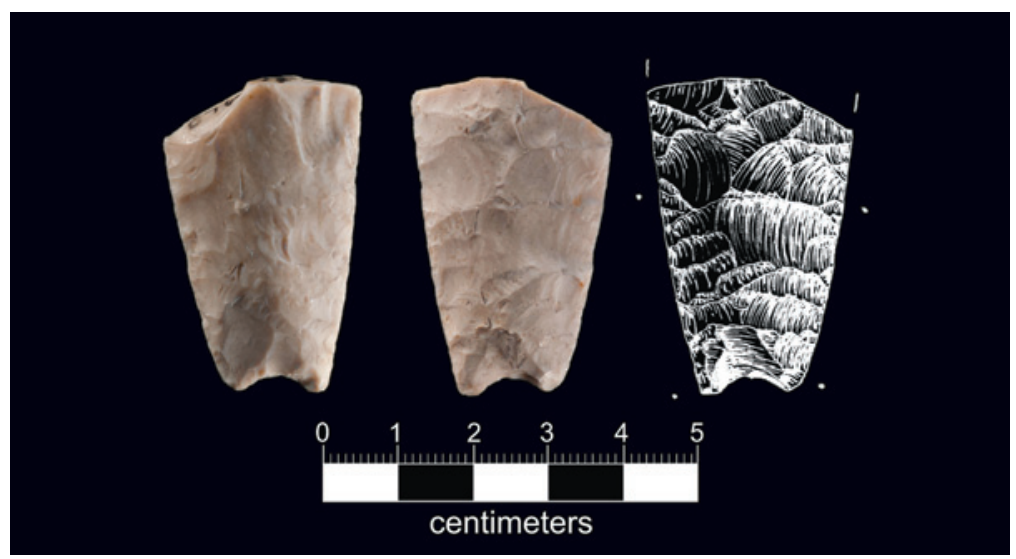

Figure 4-14. Angostura point fragment, Specimen No. 81-3.
Michael Collins (1995) places Angostura points at the beginning of the Early Archaic, although this point type has traditionally been viewed as a Late Paleoindian style. In any case, these points stylistically mark the transition from Paleoindian into Archaic times. Although points with well-made stems appeared earlier (e.g., Wilson points), following Angostura, all Archaic forms were stemmed until the Middle Archaic. Early types falling into this category have bifurcated or split-stem morphologies often grading from one type into another in terms of style and design. Archaeologists call groups of point types that strongly resemble one another in form a series (Jelks 1978); the Early Archaic series has proven extremely difficult for Texas archaeologists to separate precisely. From Spring Lake, these types include Jetta (Figure 4-26, Figure 4-27), Hoxie, Uvalde, and Gower points, all of which share stylistic similarities. A distinctive exception to this trend are side-notched Big Sandy points, which are more common in the Southeast 
(Turner et al. 2011), but also occur in Early Archaic assemblages on the Northern Plains.

Based on theoretical expectations derived from global studies of huntergatherer-fishers as well as data from South and Central Texas, the cultural landscape of the study area probably reached a critical threshold of population density by the Early Archaic. In response to this development numerous adaptations and behaviors are evident. First, since at least 7000 years ago, regional population dynamics became relatively stable, with territorial limitations imposed by what archaeologists call "population packing," or densities of more than 9 individuals per 100 square kilometers. This stability is reflected, minimally, by the appearance of cemeteries that show repeated use. In Victoria County two of the oldest cemeteries in North America, the Morhiss Site (Hard and Katzenberg 2011) and the Buckeye Knoll Site (Ricklis 2011), had been used for human interments by at least 7000 years ago, and both were intensively used for

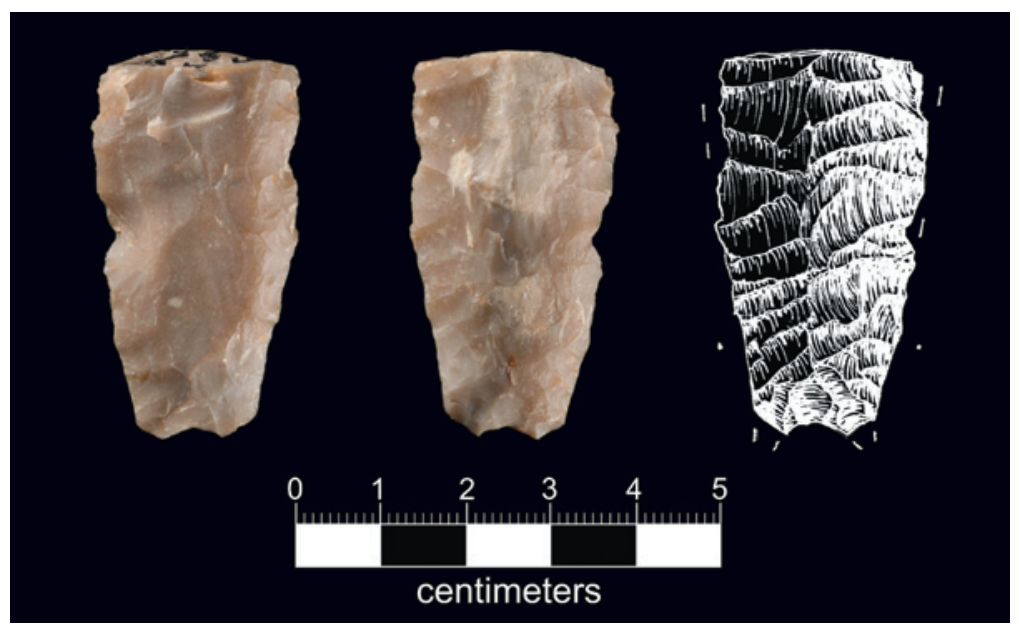

Figure 4-15. Angostura point, Specimen No. 108-1.

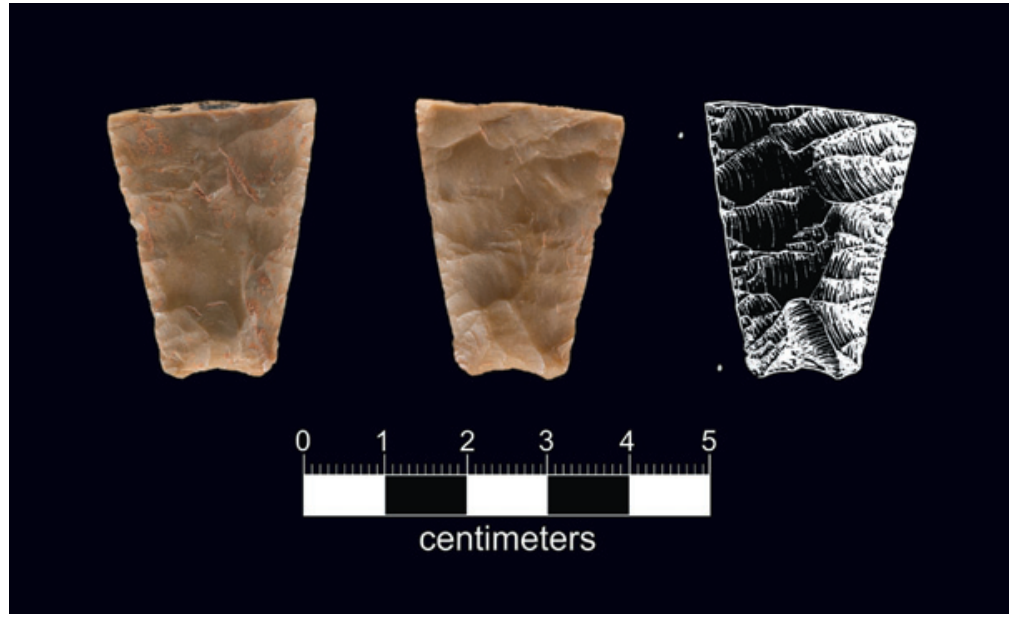

Figure 4-16. Angostura point fragment, Specimen No. 309-12.

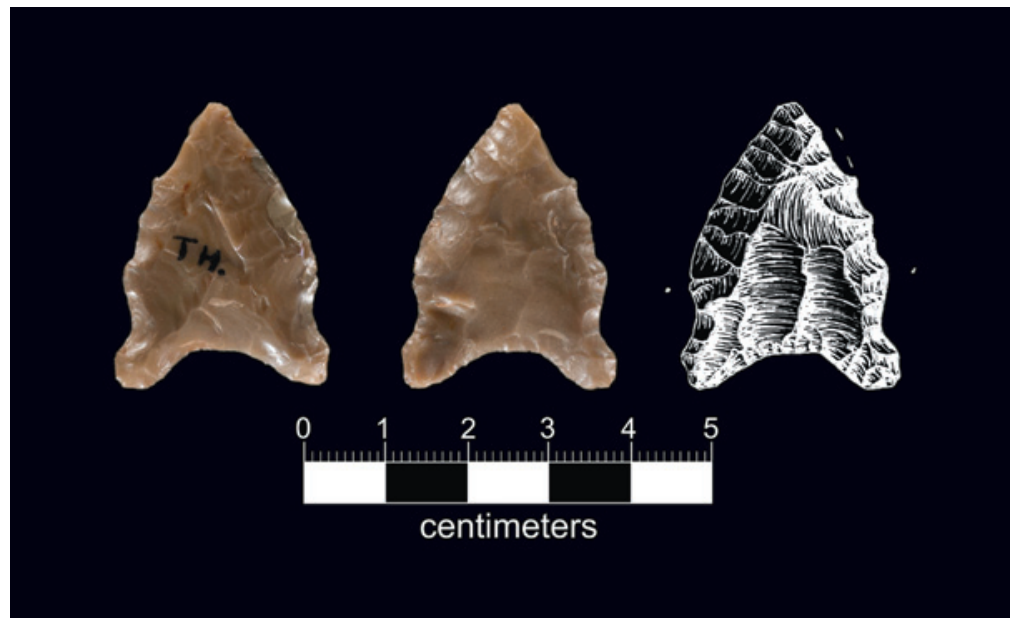

Figure 4-17. San Patrice point, Specimen No. 309-5. 


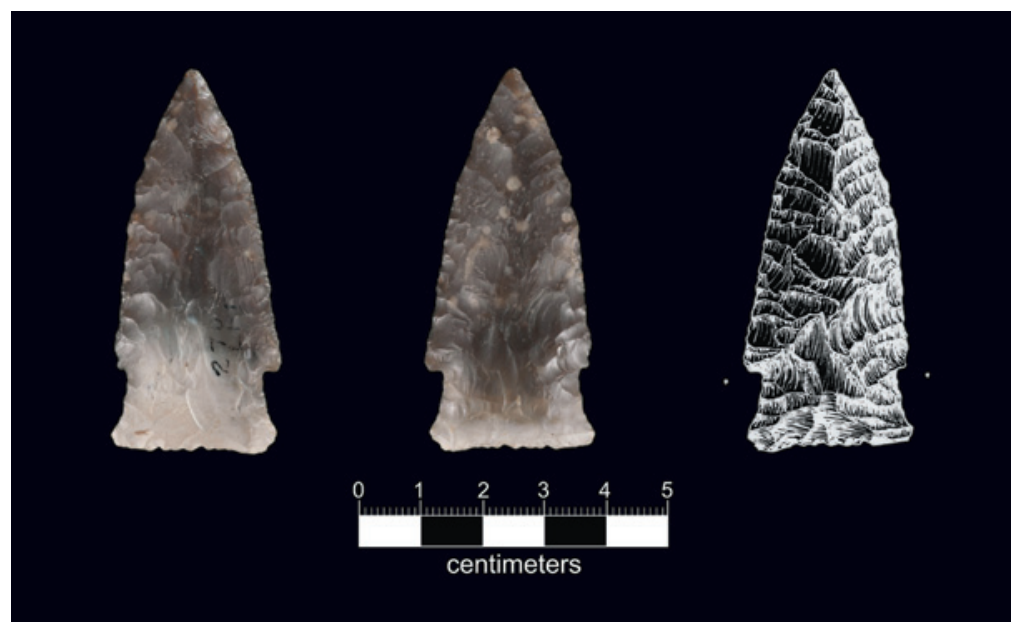

Figure 4-18. Wilson point, Specimen No. 51-1.

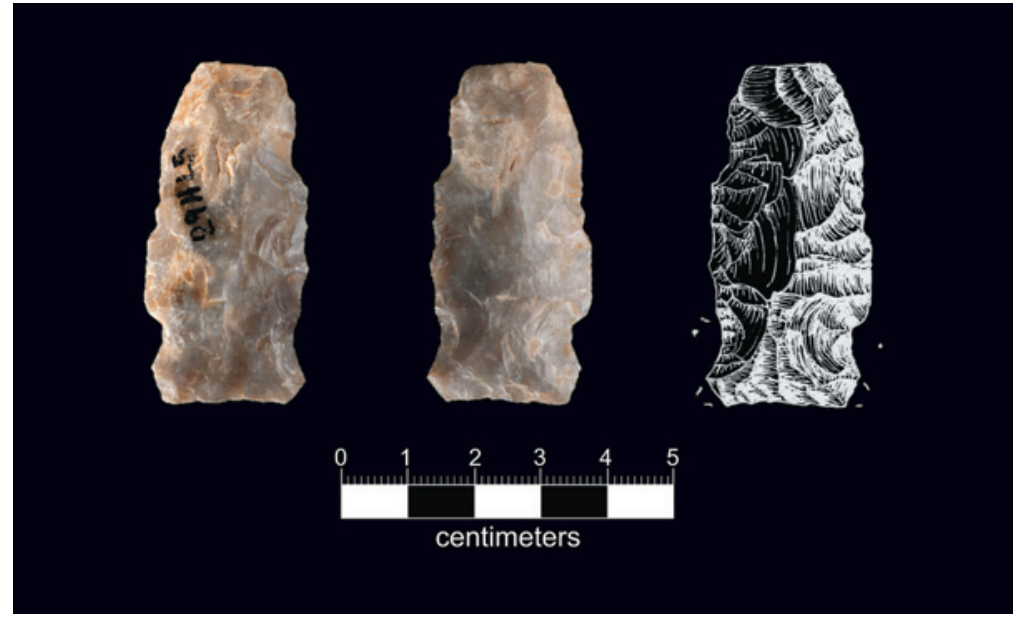

Figure 4-19. Wilson point, Specimen No. 53-1.

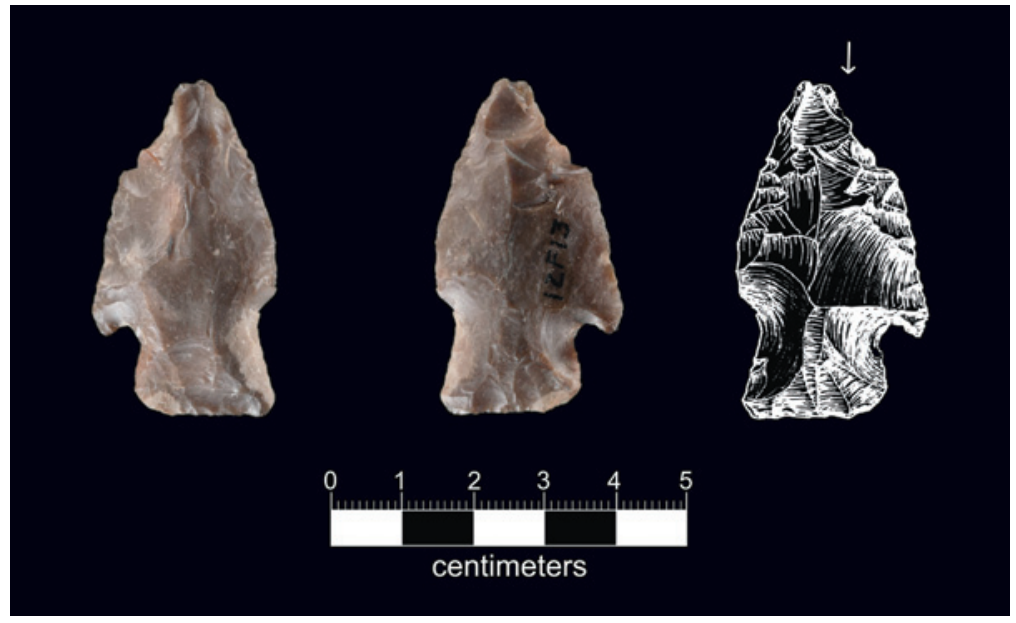

Figure 4-20. Wilson point, Specimen No. 237-1. long periods of time. Styles

of many diagnostic tool forms

commonly lasted for intervals of 300 years or more,

suggesting conservative rates of change and innovation.

The marked similarities in the Early Archaic styles noted above exemplify this conservative rate of technological change, and provide additional evidence of stability.

Lewis Binford (2001) noted that this kind of population packing is only possible through subsistence intensification (also described by Johnson and Hard 2008, and Thoms 2008), the production of greater quantities of food through increasingly labor-intensive techniques and processes. The use of hot-rock cooking technology to process wild bulbs and tubers and an increased reliance on riverine resources exemplify the subsistence intensification that occurred in Central Texas. (Prehistoric groups in the study area never practiced agriculture, which would have been the culmination of this process of subsistence intensification.) Within this gradually evolving land-use system, 
reliance on food resources that returned high yields with relatively low labor requirements for procurement and processing would have remained crucial; specifically, these resources included large game animals.

Tom Dillehay (1974) proposed a model for the Southern Plains that described the widespread presence of bison, including both the now-extinct Bison antiquus and modern Bison bison, throughout the Early Archaic. Precisely when modern bison appeared is not well known, but the antique species may have become extinct by the end of the Early Archaic. Evidence accumulated from the San Marcos area thus far neither confirms nor refutes the continuous presence of bison throughout the Early Archaic. However, numerous directly dated remains from Spring Lake establish that bison were in the region during a narrow interval from 60005750 years ago (Lohse et al. 2014). These dates are closely associated with a widespread phenomenon covering most of the Southern Plains, known as the Calf Creek horizon (Wyckoff 1994a, 1995). Calf

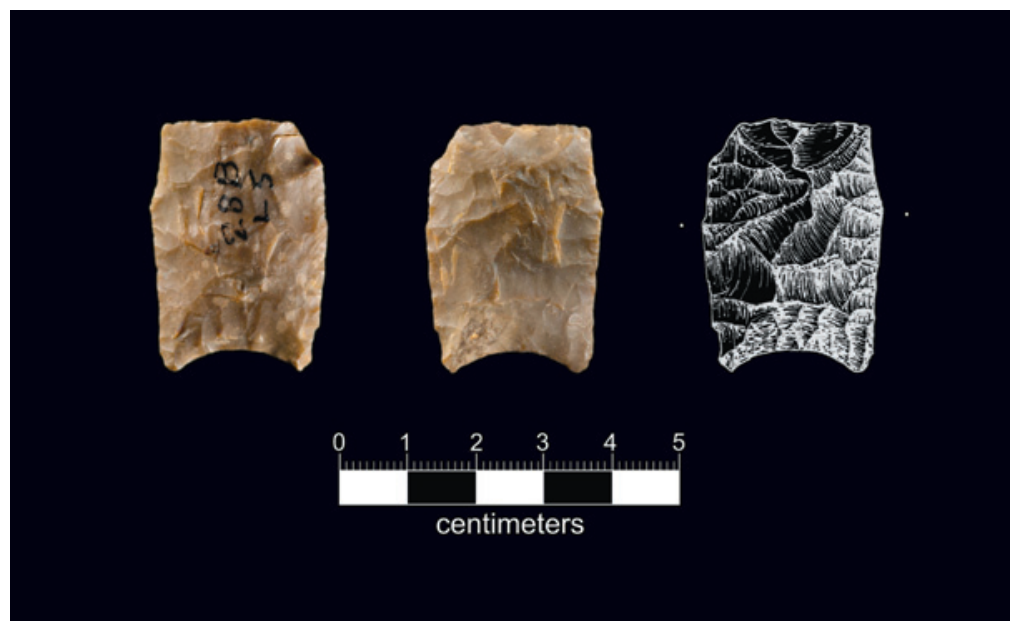

Figure 4-21. Adze made on fragment of St. Mary's Hall point, Specimen No. 292-1.

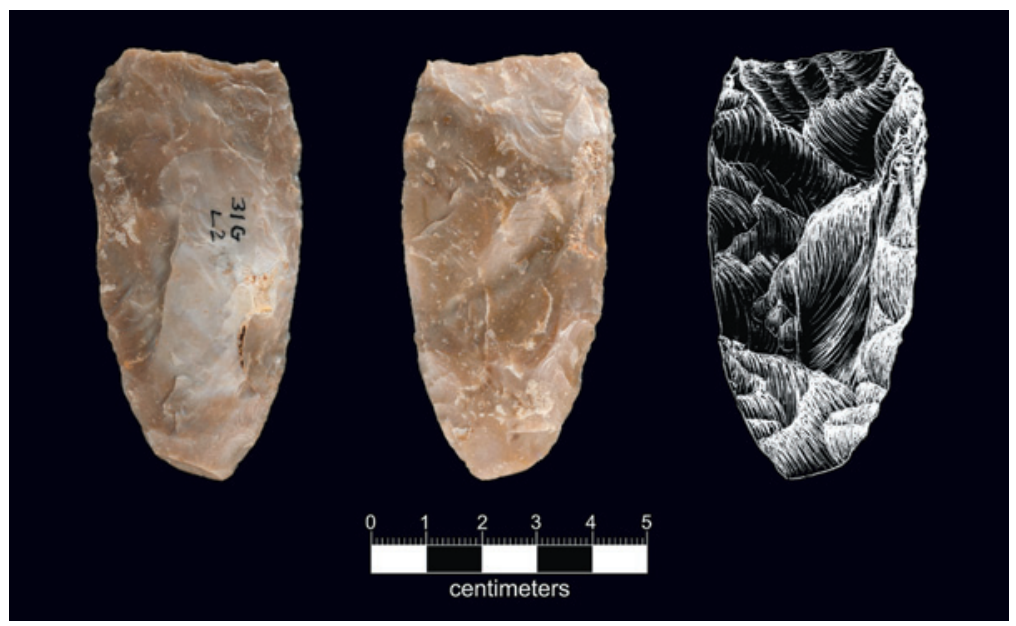

Figure 4-22. Clear Fork adze, Specimen No. 67-1.

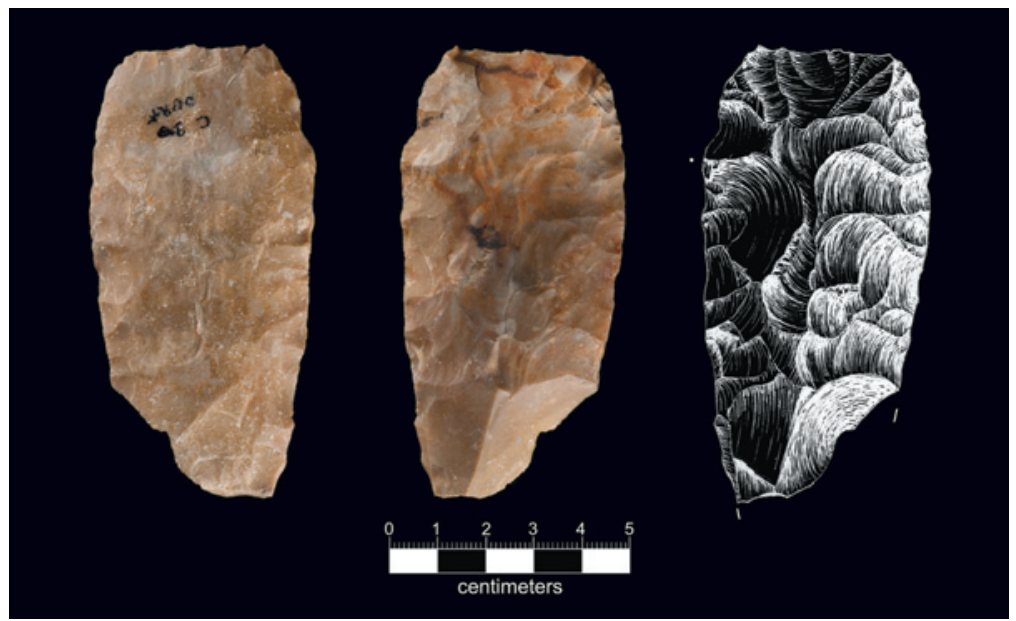

Figure 4-23. Clear Fork Adze, Specimen No. 86-1. 


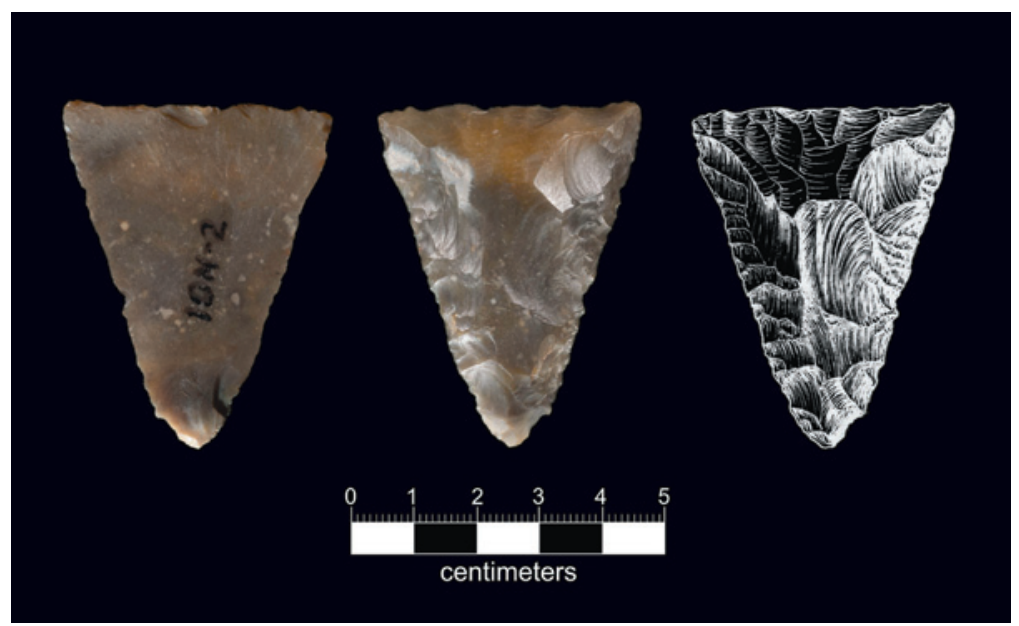

Figure 4-24. Miscellaneous adze, Specimen No. 235-1.

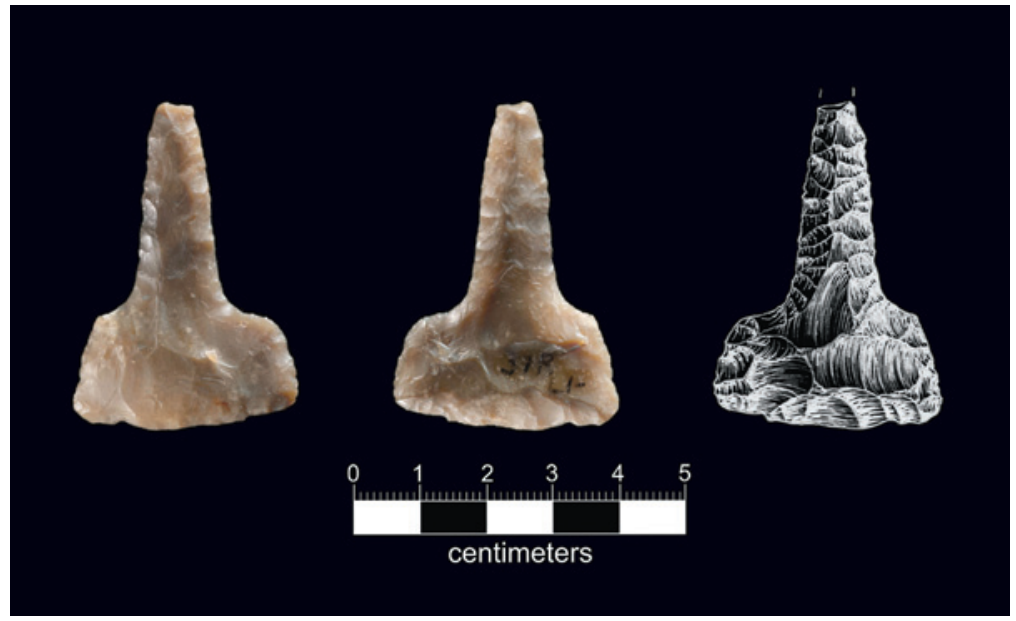

Figure 4-25. Large drill, Specimen No. 7-1.

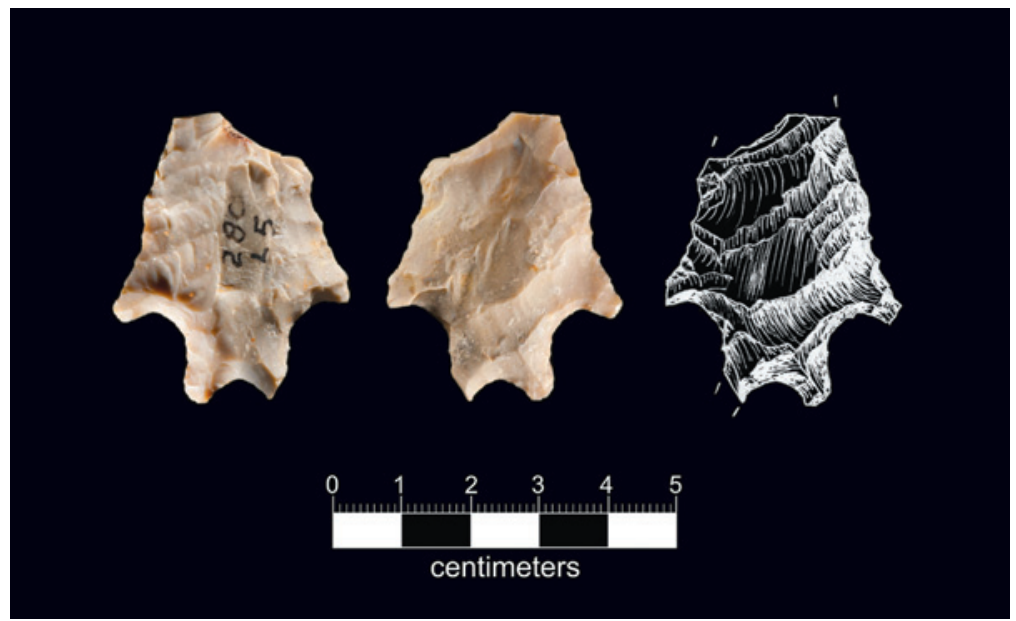

Figure 4-26. Jetta point, Specimen No. 39-5.
Creek-related point types in the study area include Bell (Figure 4-28) and Andice. These styles are closely associated with and may have derived from, or at least been influenced by similar types that are found here earlier, including Merrell (Figure 4-29), Martindale (Figure 4-30, Figure 4-31), and Bandy (Figure 4-32). Laguna (Figure 4-33, Figure 4-34), which is similar to a variety earlier called Early Barbed, is another type that seemingly predates the two Calf Creek styles (Bell and Andice), although it also remains poorly dated. The beginning of the Calf Creek horizon occurs almost exactly at 6000 B.P. and its terminal date of 5750 is clearly established by the presence of modern bison in the archaeological record at Spring Lake. We use the Calf Creek horizon to define the end of the Early Archaic.

Based on these theoretical models, plus the somewhat limited available data, the Early Archaic can be understood as a period of "settling in" across the Central Texas landscape, as it was elsewhere. This process almost certainly started during Late Paleoindian 
times, even though evidence for established regional traditions, based on cemeteries, does not appear before the Early Archaic. In addition to other laborintensive food-procurement activities, the reliance on large game, especially bison, was a very important feature of lifeways during the end of this period.

Technologically, a large degree of continuity is seen in tool and point forms during the early part of the Early Archaic. Later, Calf Creek materials, distinguished by characteristically deep basally notched, triangularform points, may have been developed from preceding point types that are similar in shape but that are corner notched (including Bandy, Merrell, and perhaps Laguna or Early Barbed). All these distinctive types are present at Spring Lake, and future research promises to shed a great deal more light on this period.

\section{Middle Archaic}

Based largely on the absence of bison in the archaeological record at Spring Lake after the Calf Creek interval, we place the beginning of the

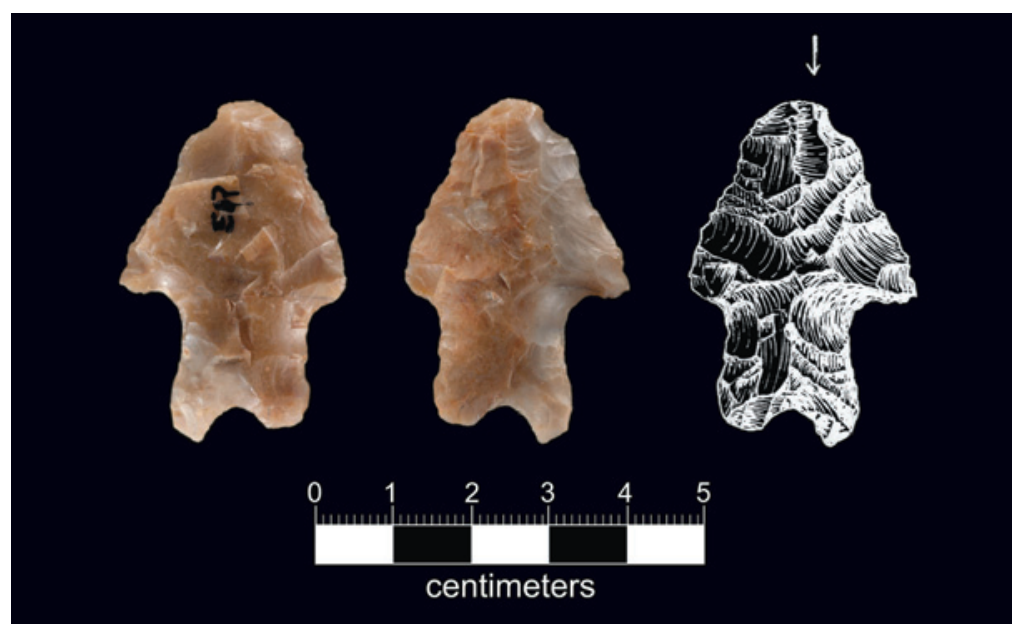

Figure 4-27. Jetta point, Specimen No. 288-1.

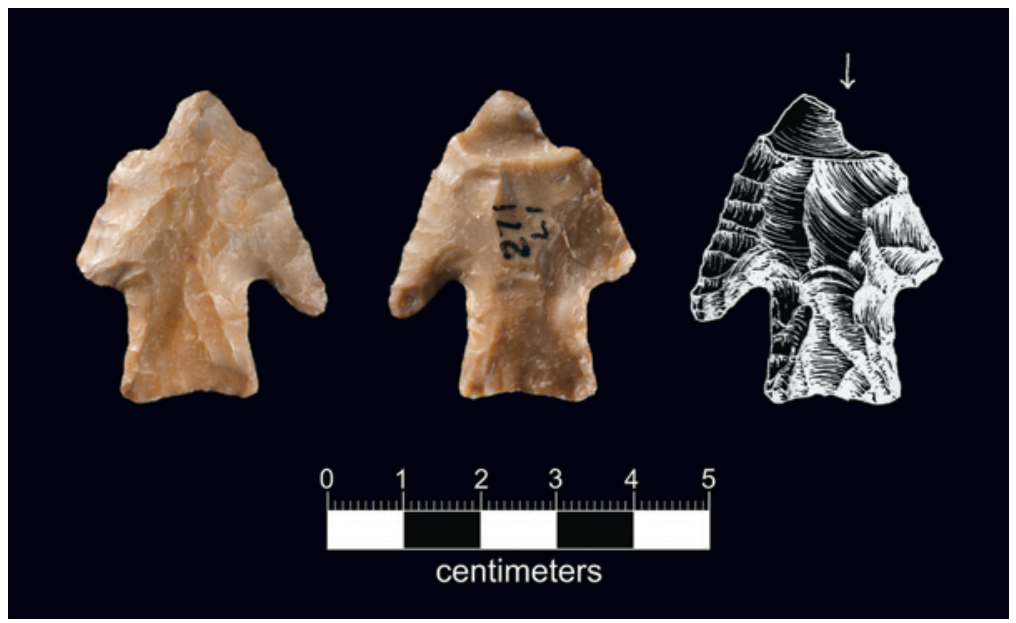

Figure 4-28. Bell point, Specimen No. 133-1.

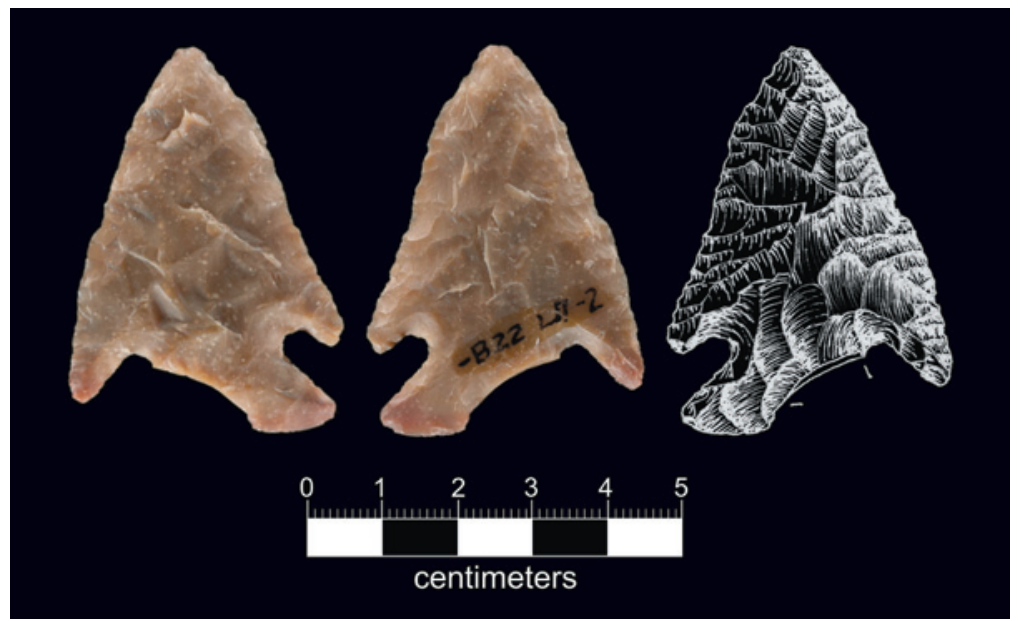

Figure 4-29. Merrell point, Specimen No. 176-1. 


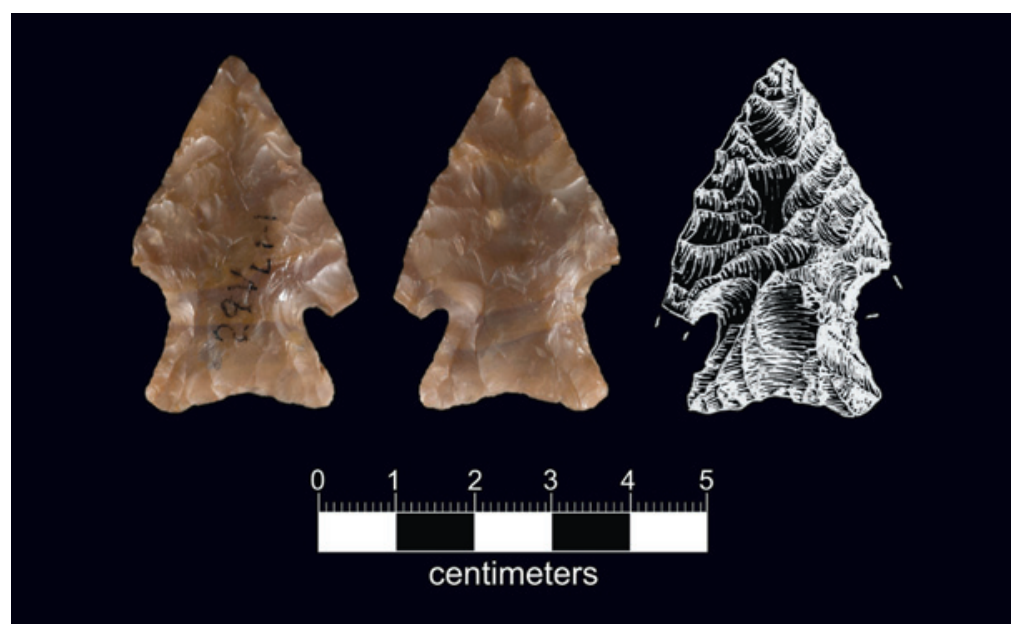

Figure 4-30. Martindale point, Specimen No. 58-1.

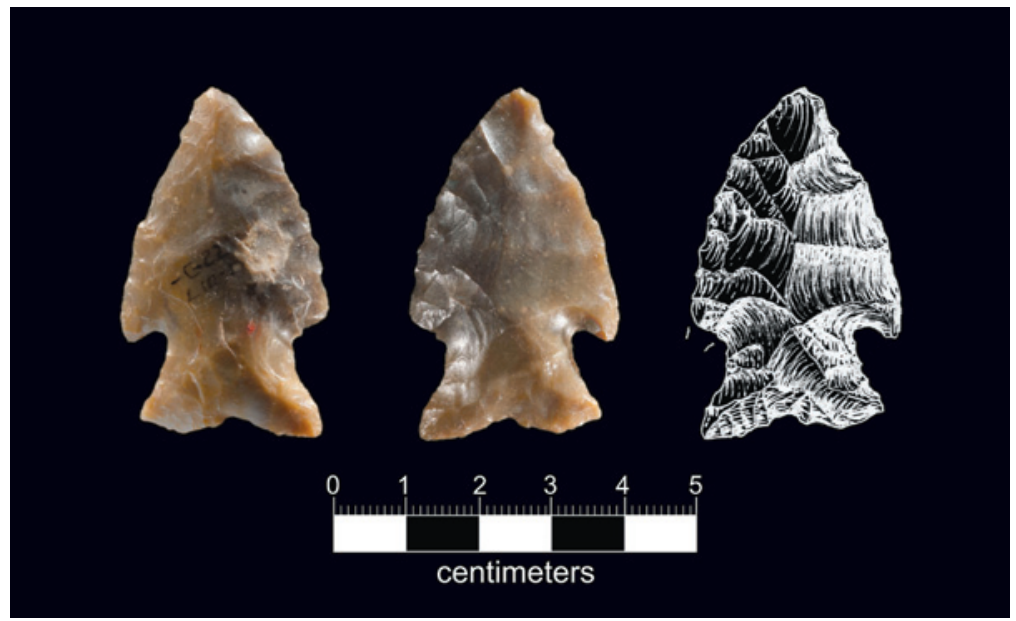

Figure 4-31. Martindale point, Specimen No. 178-2.

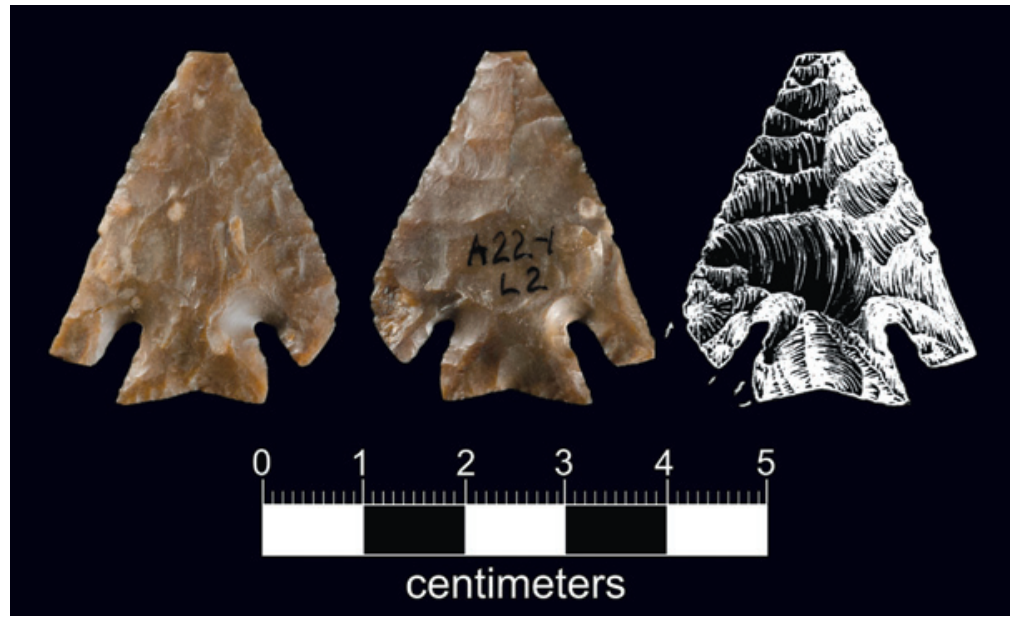

Figure 4-32. Bandy point, Specimen No. 179.2.
Middle Archaic period at approximately 5750 years ago (Figure 4-35). Regionally, the Middle Archaic is associated with the Holocene Climatic Optimum (HCO), a prolonged interval in the mid-Holocene of increasingly warm temperatures as well as increasing volatility with respect to precipitation. As the HCO progressed and conditions in South and Central Texas turned ever warmer and drier, it became ever more critical for campsites to be located near reliable water sources. Within the region, it is difficult to find any sites with intact deposits from this time period. Arid conditions affected plant growth, causing a reduction in ground cover, which in turn intensified soil erosion during rainfall events. As a consequence, archaeologists have been able to identify few landforms containing well-preserved remains from this period. The Middle Archaic deposits from Spring Lake, however, are relatively extensive, even though they appear slightly jumbled in terms of internal mixing.

Stemmed projectile point styles disappeared along with 


\section{Chapter 4}

the bison at the beginning of this period and were replaced by triangular forms called Taylor and Baird, which are commonly subsumed into one type called Early Triangular (Figure 4-36, Figure 4-37, Figure 4-38). Impact damage on some of these specimens indicates they were used in hunting. However, many other specimens were also apparently used as knives as well as for other more general purposes.

By the latter part of the Middle Archaic, stemmed projectile points, including Nolan (Figure 4-39, Figure 4-40) and Travis (Figure 4-41, Figure 4-42) types, replace Early Triangular styles. Given the poor geologic context of many sites from this period, however, the exact time of this transition

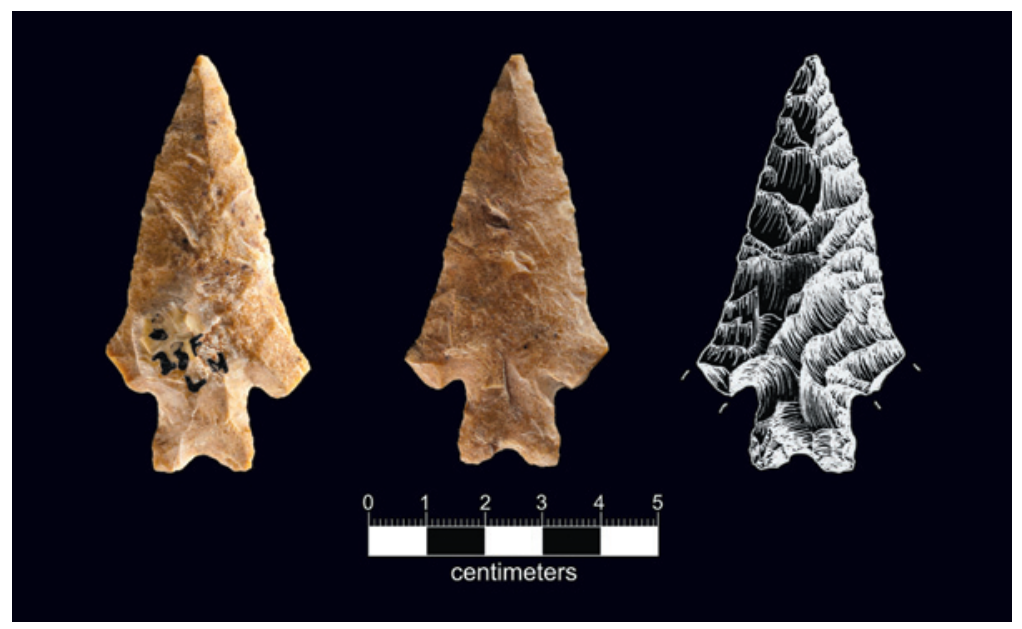

Figure 4-33. Laguna point, Specimen No. 33-1.

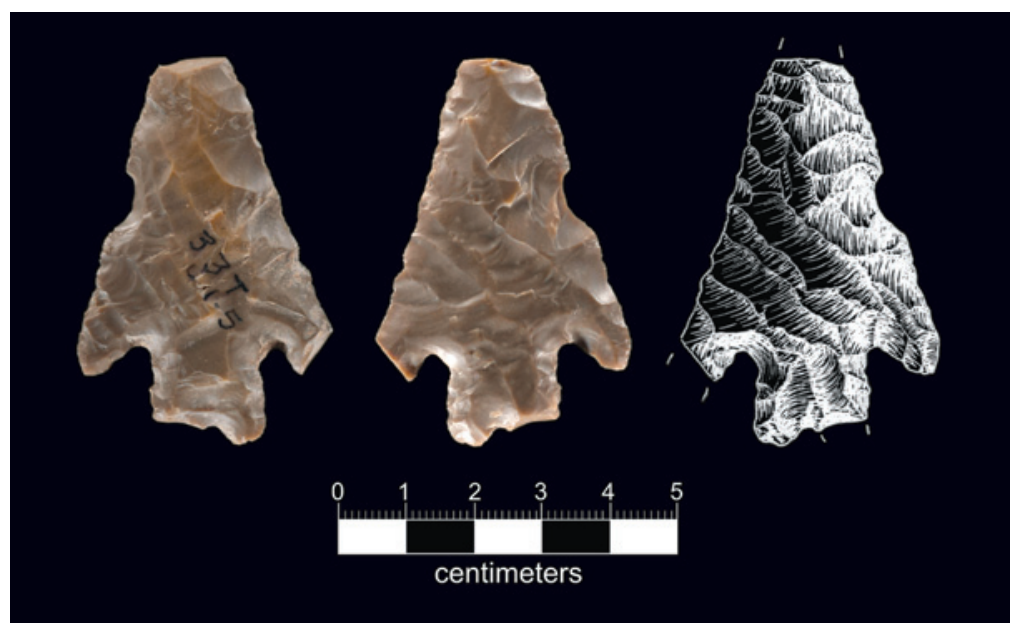

Figure 4-34. Laguna point, Specimen No. 159-2. has not yet been clearly dated. While both Nolan and Travis are distinct from earlier styles, they are highly comparable to each other, and also to newly defined types that grade into the early part of the following Late Archaic Period. For instance, the recently defined Evant point type (see Chapter 3), which is present at Spring Lake, suggests a continuous sequence of occupation through the Middle Archaic into later time periods. We date the end of the Middle Archaic at around 4200 to 4100 years ago. This probably represents the culmination of the climatic trends that began almost two millennia before (Lohse et al. 2014).

\section{Late Archaic}

The Late Archaic represents in many ways a continuation of the preceding period. However, its duration was longer, approximately 3500 years, lasting from around 4200 years ago until A.D. 1300. Accordingly, it encompasses much more variation in projectile point styles and associated 


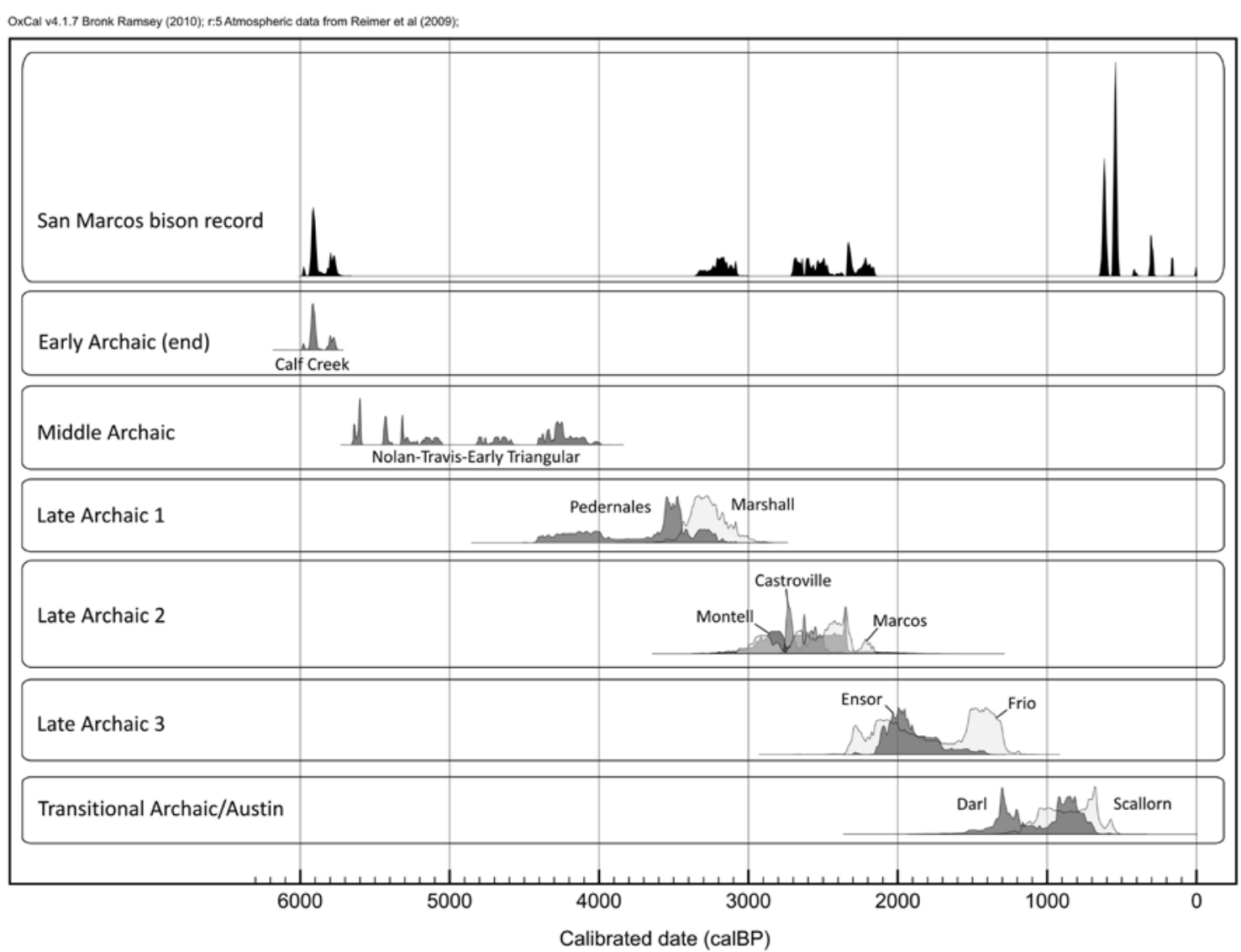

Figure 4-35. Diagram of the time-ordering of Archaic periods, starting with Calf Creek and the end of the Early Archaic, based on calibrated radiocarbon data plus evidence for bison exploitation. Black or gray shaded areas represent the probability distribution of the best available radiocarbon dates for that period or point type. All dates are shown in calendar years before present (from Lohse et al. 2014).

cultural patterns than is seen in the Middle Archaic. The Late Archaic is long enough that we subdivide it into smaller periods, both for the sake of convenience but also to better recognize significant developments that took place within the Late Archaic. Late Archaic I lasted from approximately 4200 to 3100 years ago. Late Archaic II dates from about 3100 to 2150 years ago. The final period, Late Archaic III, lasted from 2150 to approximately 1270 years ago. (The precision implied by these dates should not be taken literally; these age ranges are only approximations based on available data). Periods of bison hunting, evidenced by the record of 55 high-precision dates taken directly from remains excavated from Spring Lake and the nearby site 41HY188 help to provide a basis for distinguishing between these subperiods (see Figure 4-35).

Late Archaic I at Spring Lake is characterized by two diagnostic point types, Bulverde (Figure 4-43, Figure 4-44) and Pedernales (Figure 4-45, Figure 4-46, Figure 4-47), as well as 
less common forms such as Marshall and Lange.

Pedernales points, in particular, are among the most common point types of any period in the region, and some archaeologists have postulated that the frequency of this type reflects high overall populations in Central Texas. This period includes the first reappearance of bison into the region since Calf Creek times, around 3200 years ago. Whether Pedernales points are associated with bison has yet to be demonstrated. Other types, specifically Marshall, seem to be good candidates for association with bison remains.

Late Archaic II is defined almost exclusively by the close association of a distinctive series of types, including Montell (Figure 4-48, Figure 4-49, Figure 4-50), Castroville (Figure 4-51, Figure 4-52, Figure 4-53), and Marcos (Figure 4-54, Figure 4-55, Figure 4-56), with bison hunting across much of Central Texas and beyond. All three of these types occur at Spring Lake, and a number of bison remains have been directly dated to this interval.

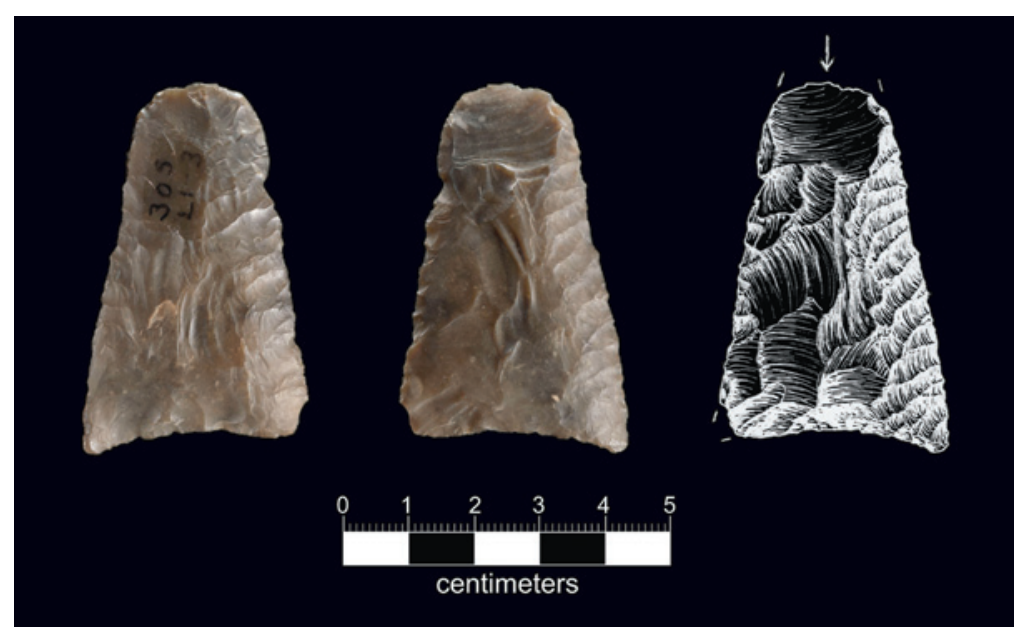

Figure 4-36. Early Triangular point, Specimen No. 89-1.

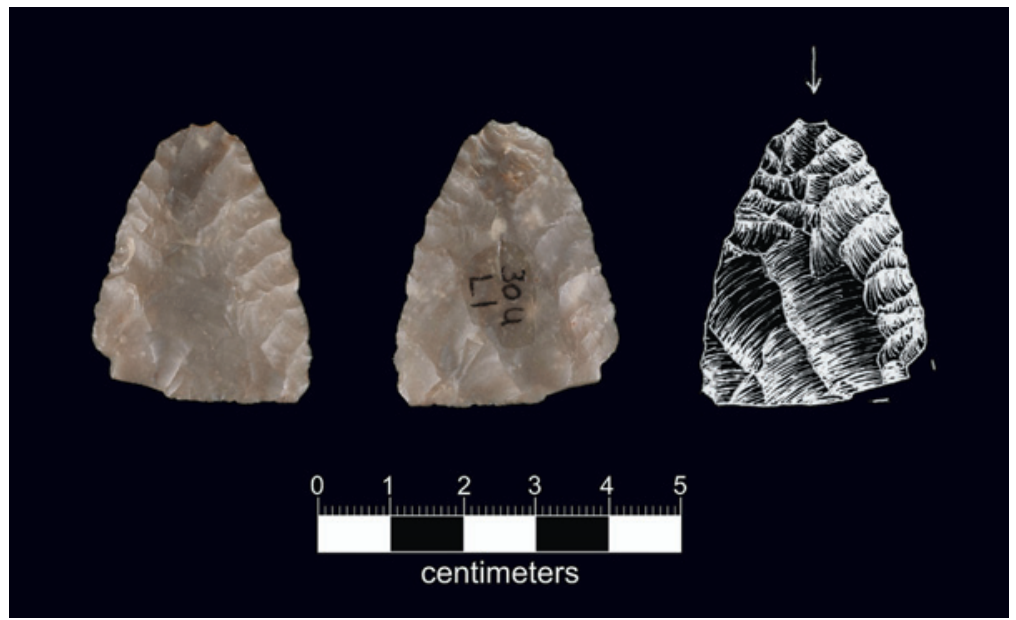

Figure 4-37. Early Triangular point, Specimen No. 90-2.

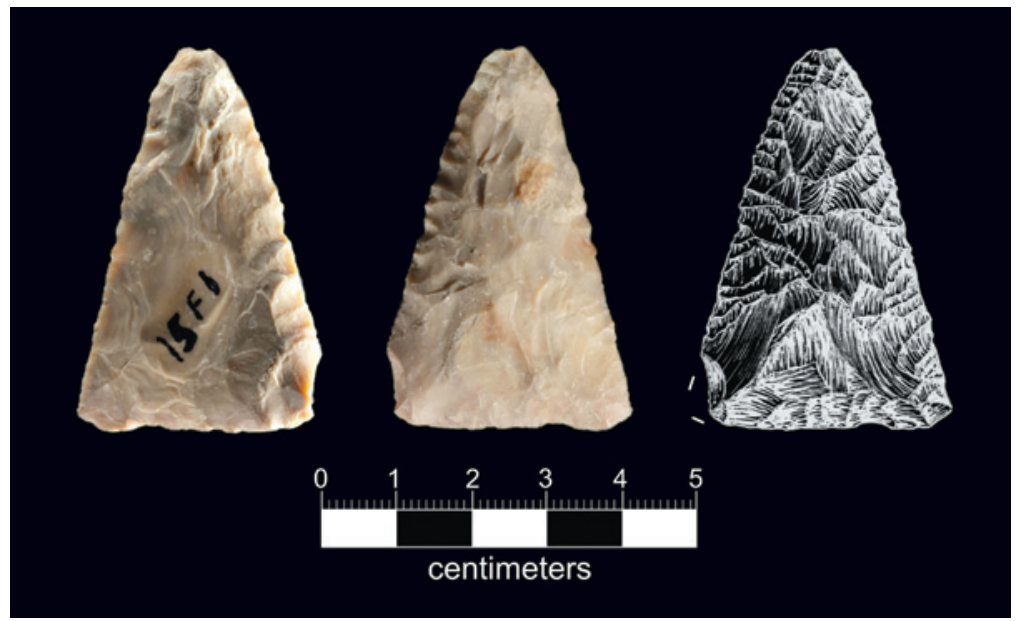

Figure 4-38. Early Triangular point, Specimen No. 250-1. 


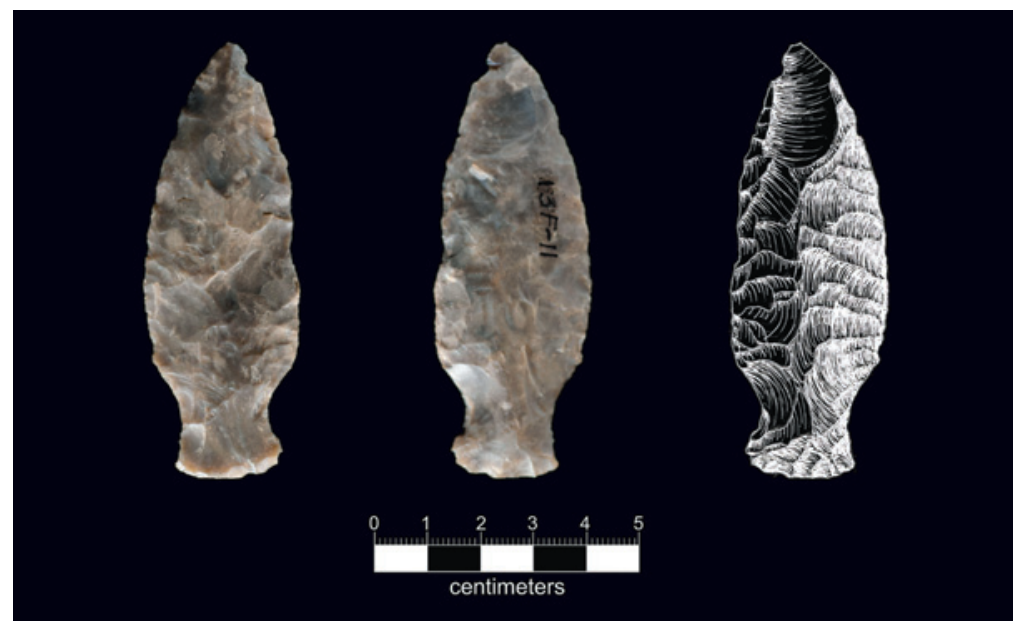

Figure 4-39. Nolan point, Specimen No. 3-1.

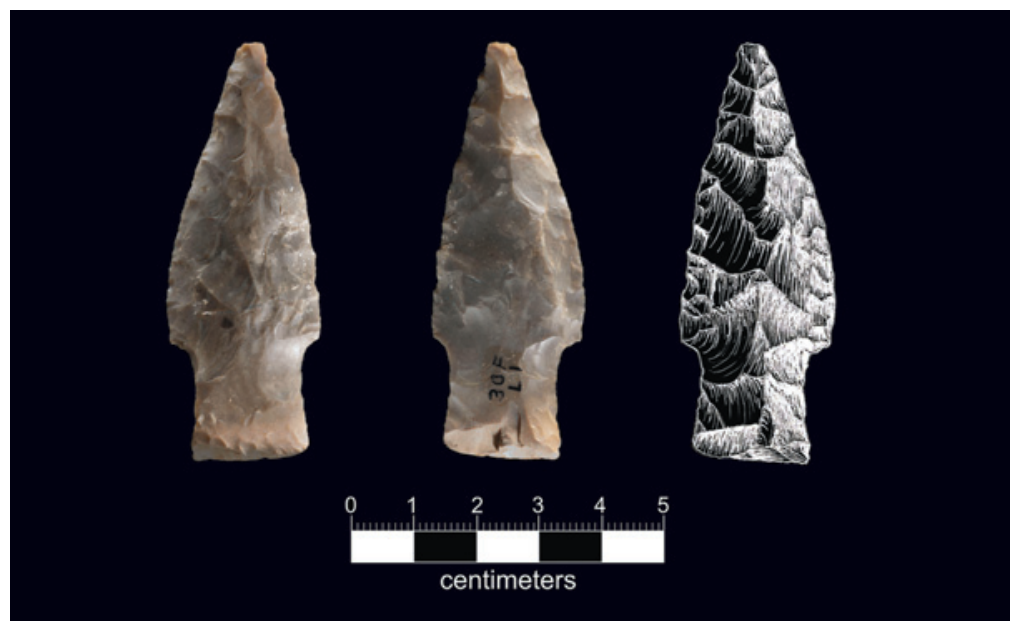

Figure 4-40. Nolan point, Specimen No. 93-1.

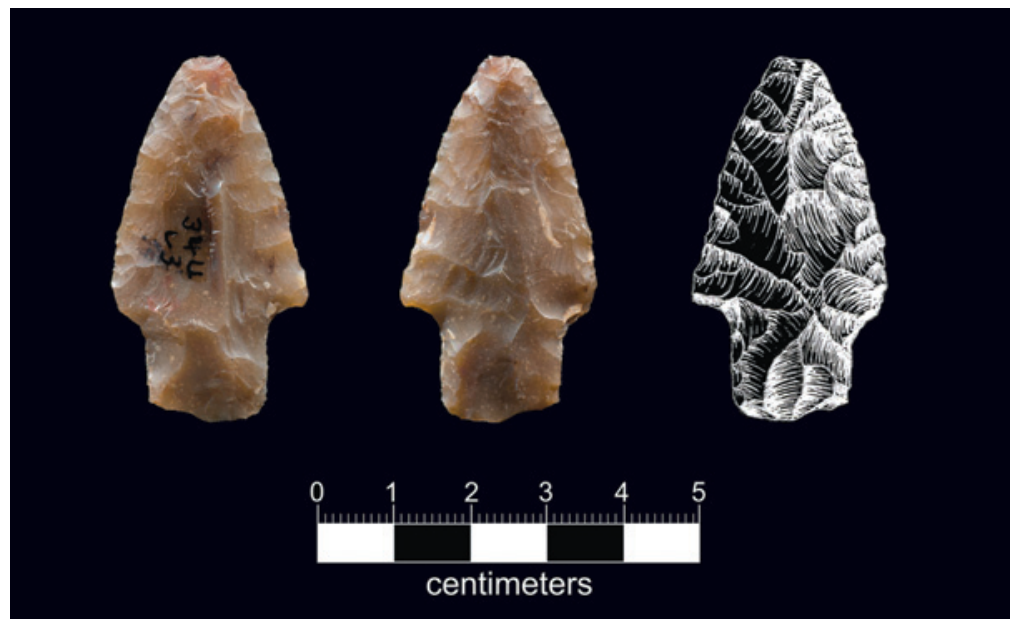

Figure 4-41. Travis point, Specimen No. 202-1.
Our Late Archaic III period seems to represent the onset of another prolonged time interval when bison were absent from the study area. Work at Spring Lake indicates that these animals, which had previously played a fundamental role in local subsistence practices, disappeared from the regional landscape somewhat abruptly around 2150 years ago.

Many sites farther north, near the Texas-Oklahoma border, have provided strong evidence for continued bison hunting. It appears that as a result of changes in climate at this time, the regional environment near Spring Lake may no longer have supported enough forage to sustain the bison herds that had previously ranged here. Late Archaic III diagnostic points recovered from Spring Lake include Ensor (Figure 4-57, Figure 4-58), Fairland (Figure 4-59), Frio and others.

Aside from the changes in bison frequencies in the region throughout the Late Archaic, many archaeologists view this as a period of relative continuity and cultural stability. Many of the subsistence strategies, technological choices, and 
patterns of site location remained relatively constant for more than 3000 years.

One significant development that reemerged during this time was the establishment once again of several large cemeteries that seem to mark regional territories. Although some Middle Archaic interments are known, the scale and magnitude of burial practices in the Late Archaic exceeds that known for any previous time period. Cemeteries at sites such as Ernest Witte in Austin County (Hall 1981) and Olmos Dam in San Antonio (Lukowski 1988) may suggest that populations increased and that some groups were once again establishing territorial ranges (Story 1985:44-45).

\section{Transitional Archaic/Austin}

Traditionally, the appearance of the bow and arrow, visible in the record with the introduction of Scallorn points around A.D. 800, has been used to mark the end of the Archaic and the beginning of what archaeologists call the Late Prehistoric period. No one yet knows, however, precisely when the bow and arrow were first used in

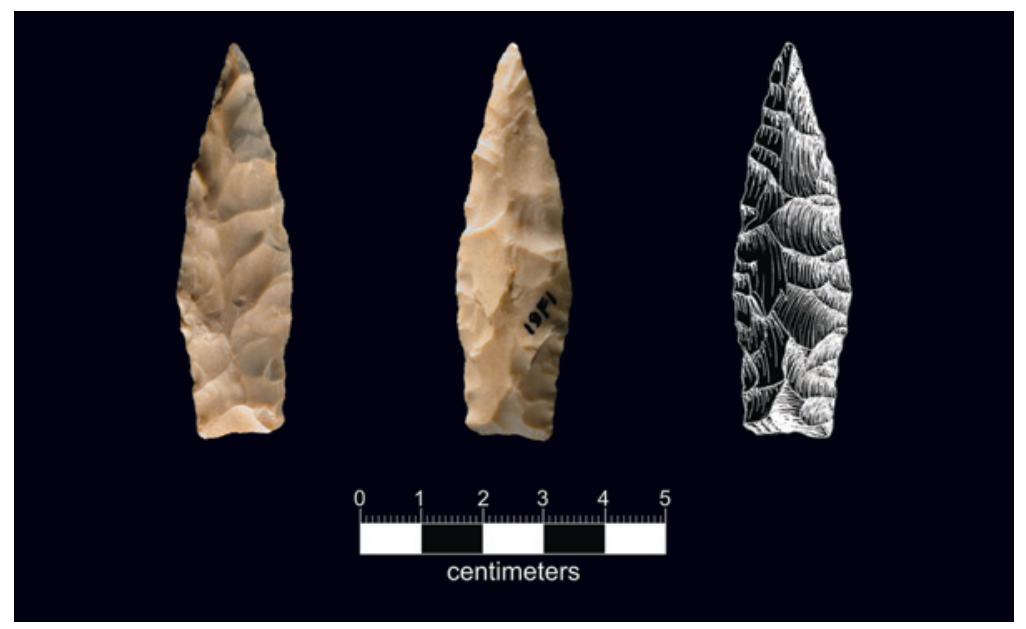

Figure 4-42. Travis point, Specimen No. 304-1.

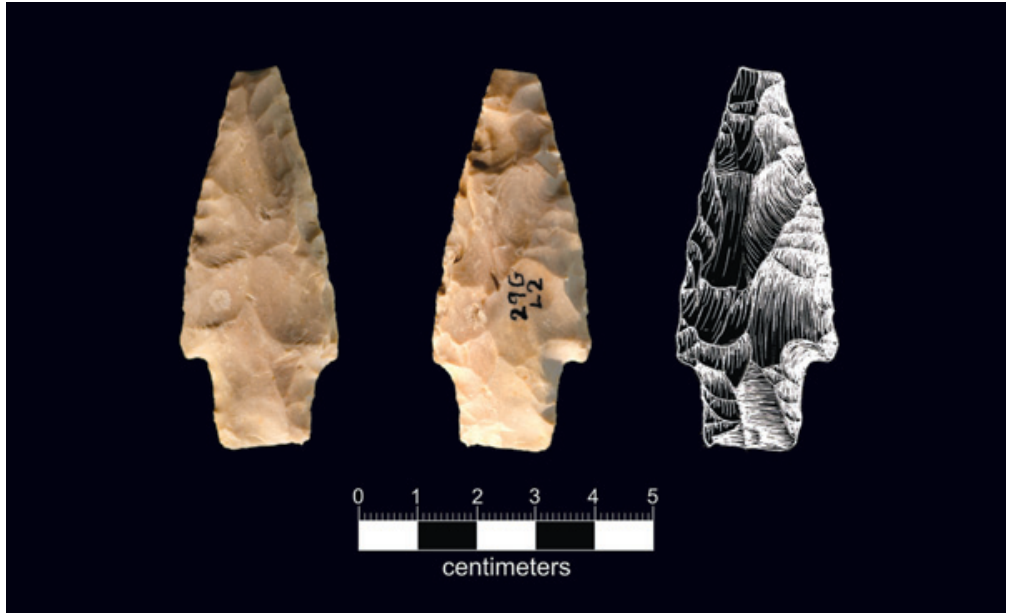

Figure 4-43. Bulverde point, Specimen No. 29-2.

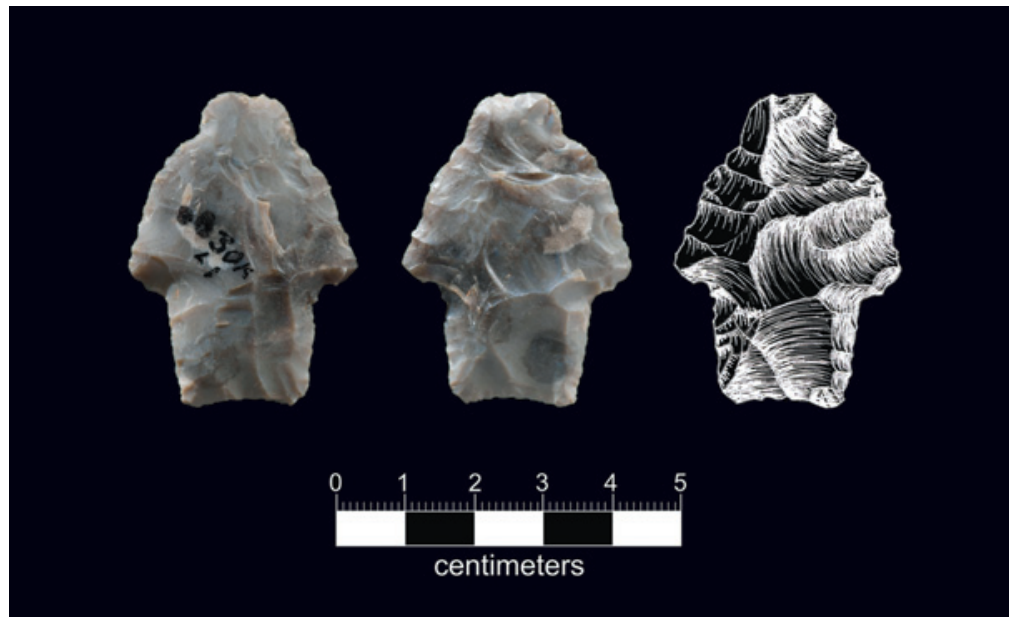

Figure 4-44. Bulverde point, Specimen No. 85-1. 


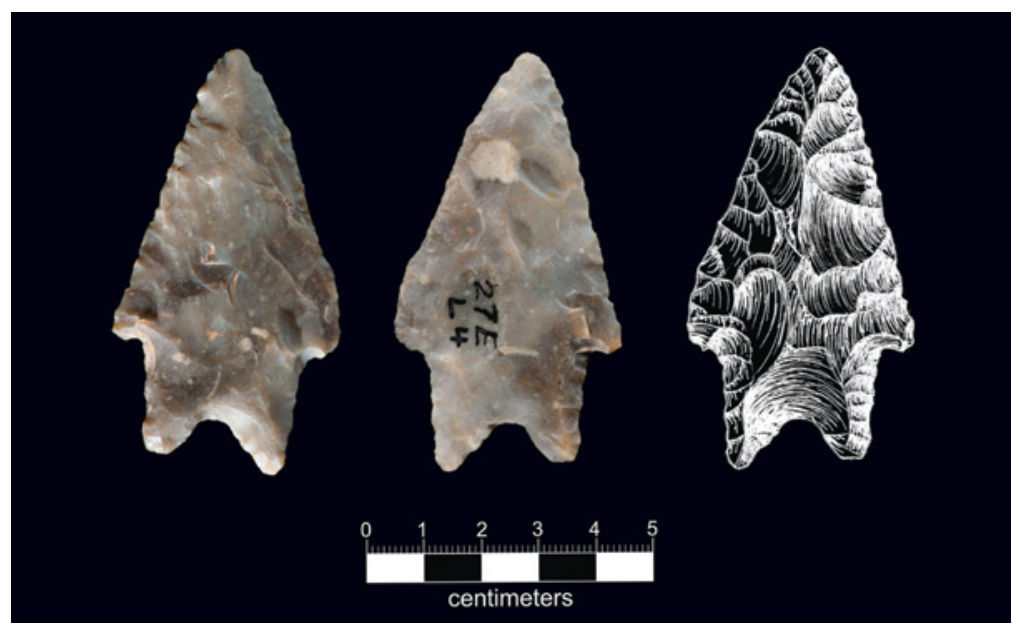

Figure 4-45. Pedernales point, Specimen No. 8-1.

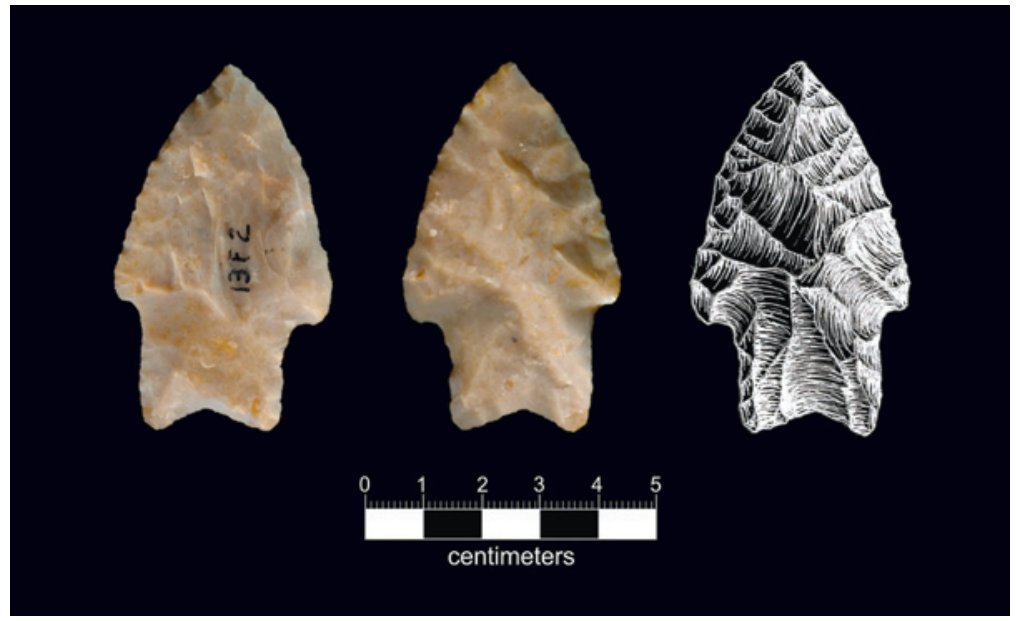

Figure 4-46. Pedernales point, Specimen No. 10-1.

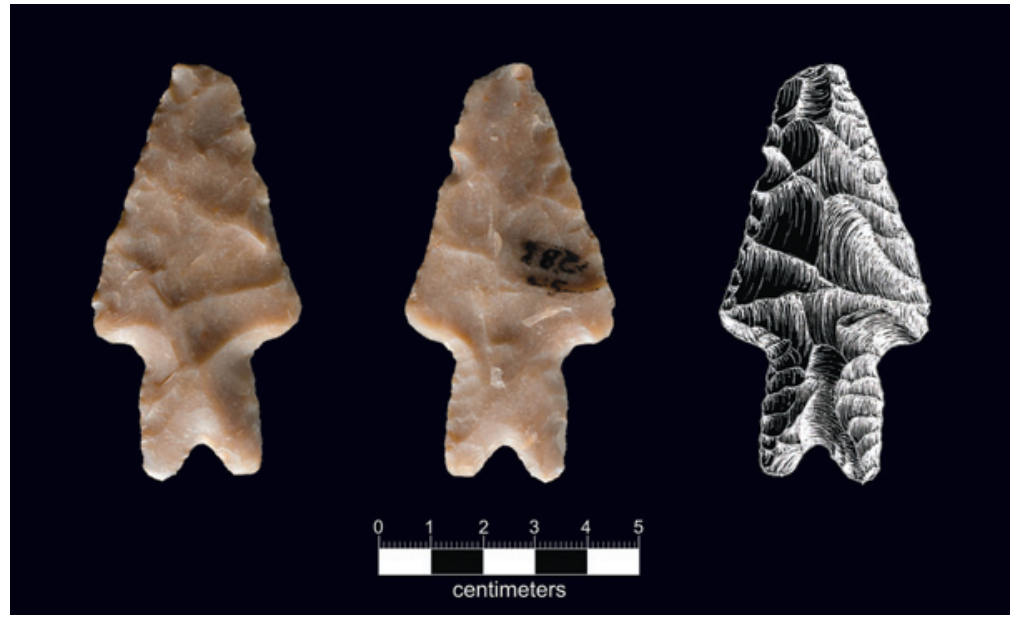

Figure 4-47. Pedernales point, Specimen No.39-4.
Central Texas, and it seems likely that this technological adaptation was gradual rather than abrupt. Although the bow and arrow represents a significant development over previous methods for hurling spears and darts at game animals (or people), the overall record of the region shows a great deal of continuity in almost all other respects, suggesting that the bow and arrow did not actually mark a significant shift in many cultural patterns (see recent summary by Arnn 2012:167-168).

Some examples of behavioral continuity include a broadspectrum diet, continued reliance on bifacial stone tool technologies, mortuary practices, increasing reliance on hot rock cooking techniques and the plant foods associated with these ovens, and site distribution and settlement patterning. In view of the evidence for cultural continuity, we have defined the end of the Archaic by combining what some have called the Transitional Archaic with the Austin phase, which is characterized by the bow and arrow and which until now has marked the beginning of an altogether 
new temporal unit, the Late Prehistoric (Lohse et al. 2014).

Evidence from bison remains provides another compelling reason for defining the end of the Archaic in this manner. Following the Late Archaic II, no bison remains from Spring Lake have been dated to earlier than A.D. 1300, a hiatus of over 1500 years. Among all of the available classes of data that can be used to address this part of the regional chronology, this distinction is among the clearest and best defined. In contrast, a review of existing radiocarbon dates from across the region shows the continual, gradually changing preference for time-diagnostic point types, from Ensor and Frio to Darl and Scallorn (Figure 4-60), the earliest arrow point type known in the study area (see Figure 4-35). In some regions, particularly south of Spring Lake along the southern margin of the Balcones Escarpment west of San Antonio, the Edwards arrow point type (Figure 4-61) is also common. In Shiner's material from 41HY147, this transitional period out of the Archaic is

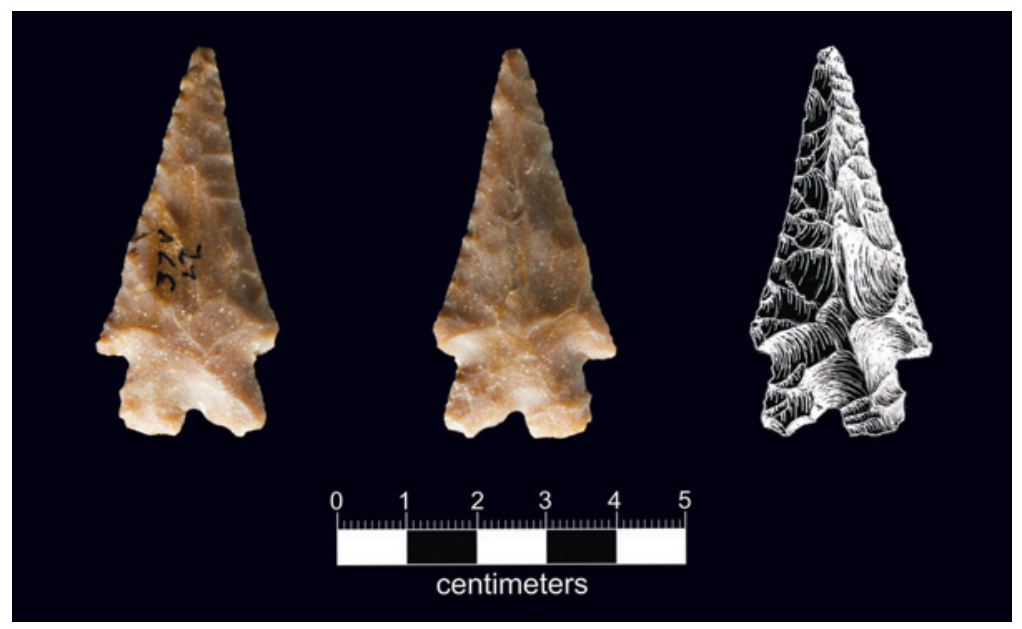

Figure 4-48. Montell point, Specimen No. 11-1.

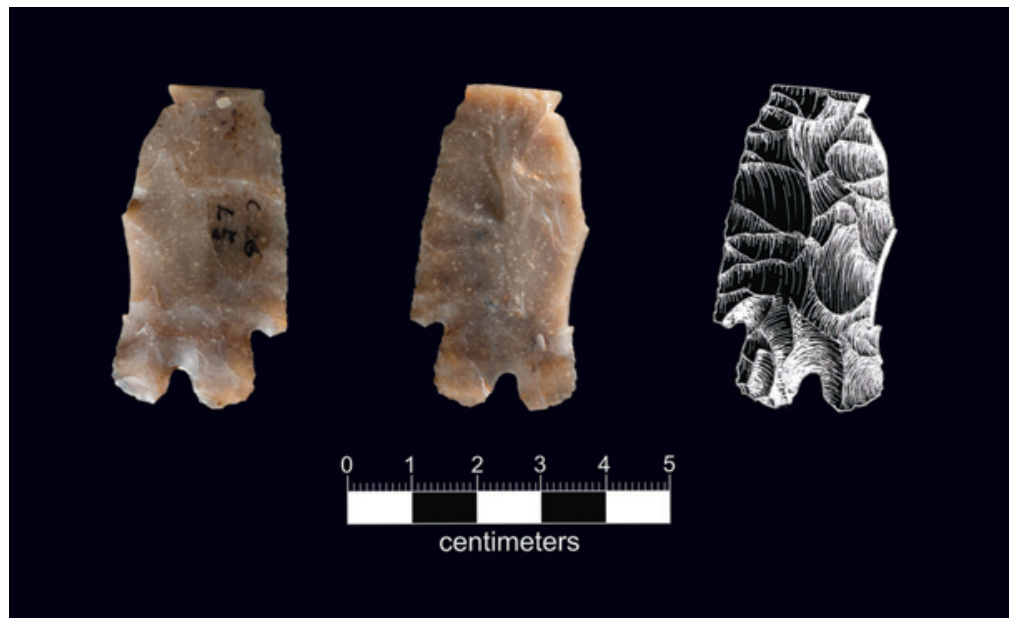

Figure 4-49. Montell point, Specimen No. 20-1.

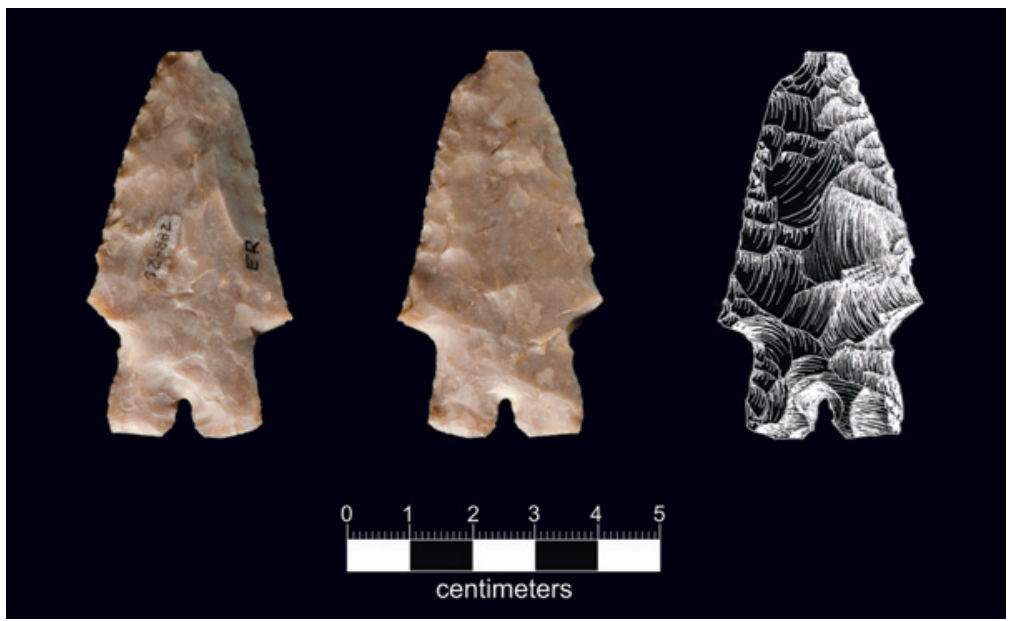

Figure 4-50. Montell point, Specimen No. 288-25. 


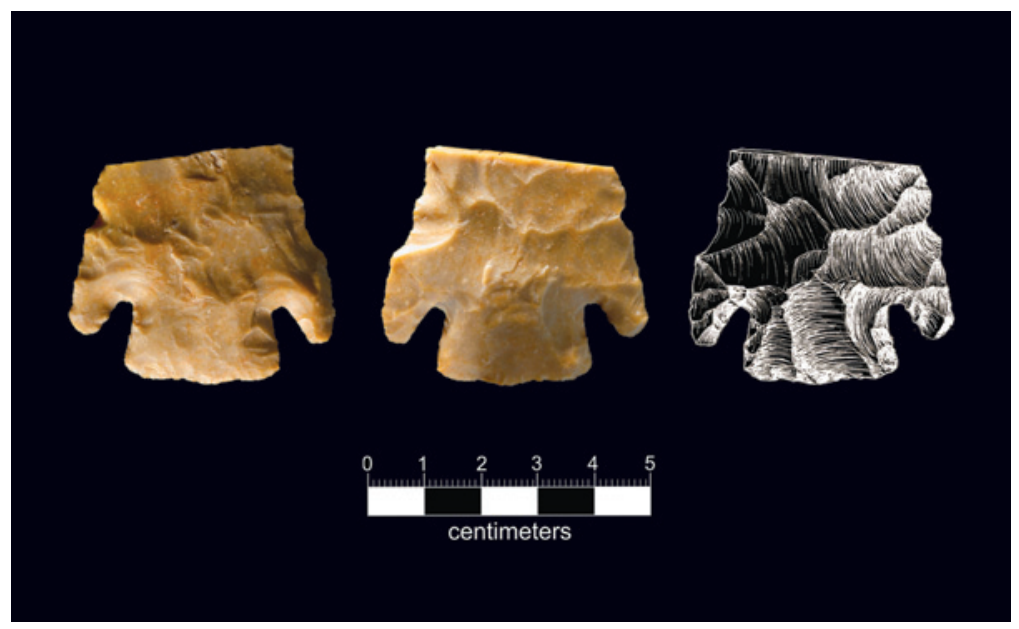

Figure 4-51. Castroville point, Specimen No. 17-1.

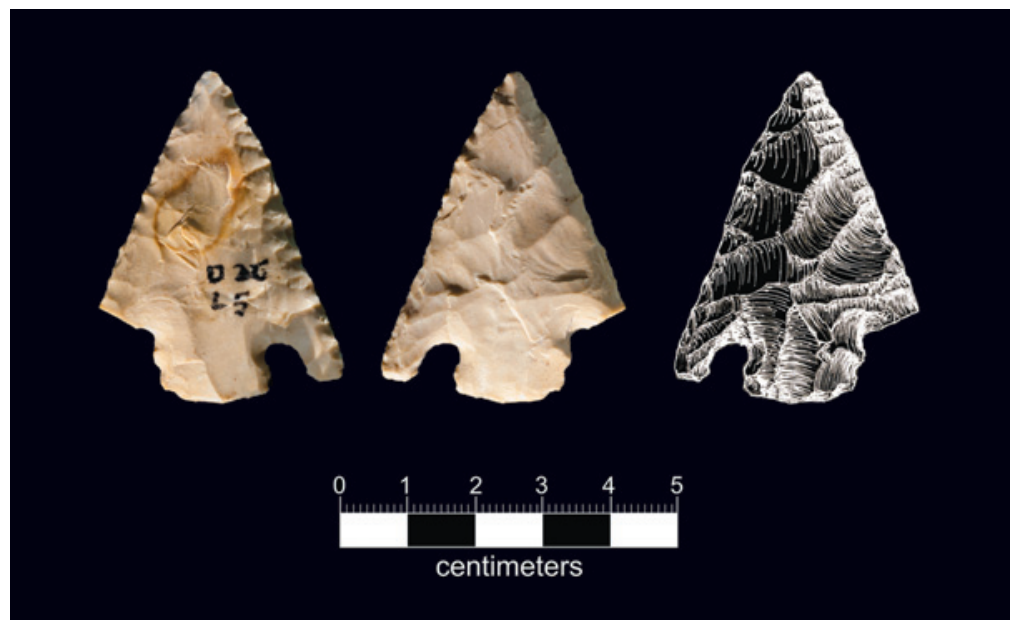

Figure 4-52. Castroville point, Specimen No. 23-6.

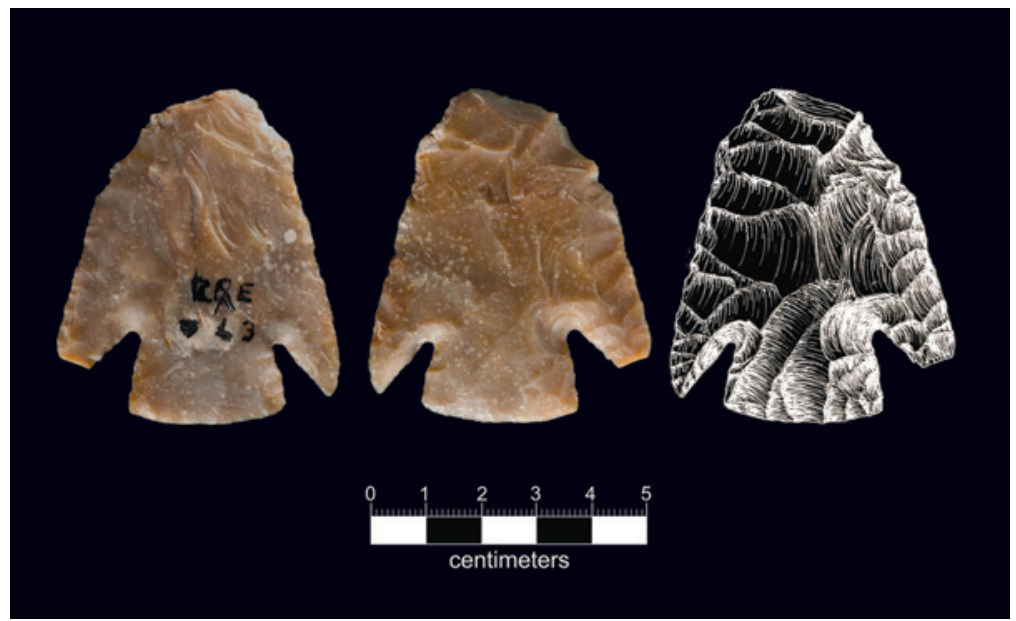

Figure 4-53. Castroville point, Specimen No. 309-13. not as strongly represented as earlier transitional periods (see discussion of Ensor, Frio, Fairland, Darl, and Scallorn points in Chapter 3). Nevertheless, examples of each of these types is present, and other excavations across the area have recovered additional evidence from this period.

\section{Late Prehistoric}

Texas archaeologists have customarily divided the Late Prehistoric period into two phases, Austin and Toyah. As discussed above, we include the Austin phase with the Transitional Archaic, thereby specifically limiting the Late Prehistoric in Central Texas to the Toyah interval, which seems to have started immediately around A.D. 1300. John Arnn (2012) has described Toyah as a time when coalitions of Native American groups were actively traversing the Central Texas region, resulting in widely shared artifact technologies and styles. Other archaeologists have argued persuasively that one primary impetus to this shift in mobility and cultural interaction was an intense, focused exploitation 
of bison. At this time, many

Plains cultures far to the north of Central Texas were actively exchanging bison meat and hides with Pueblo villages to the west as well as with complex societies in the Mississippi River drainages and tributaries to the east (Spielman 1991). Trade goods from external regions, including obsidian, turquoise, and exotic ceramic styles appear more commonly than in previous times, providing evidence that supports this model (e.g., Kibler 2012). Additionally, the previously described female burial recovered many years ago from the University's main campus was shown by carbon and nitrogen isotope data to have come from the Texas Coast (Munoz et al. 2011; Stull and Hamilton 2011). Early-period historical accounts detail how, in order to provide additional labor to process bison, tribes commonly exchanged marriage partners. This individual, who was probably not originally from the study area, may represent an early example of this practice.

Dating the end of Toyah is complicated, as several material traits clearly extend

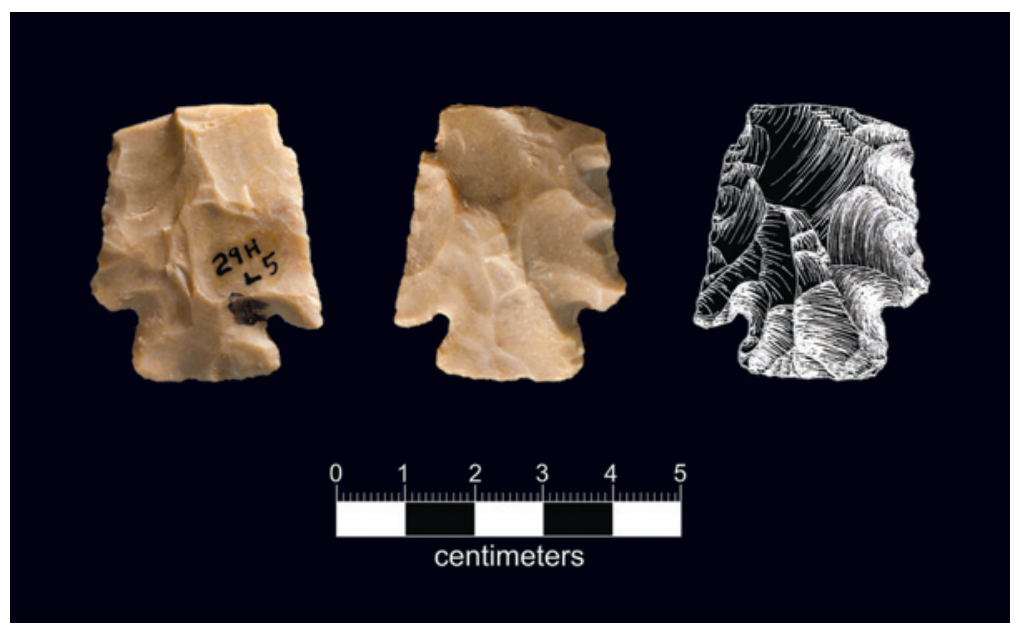

Figure 4-54. Marcos point, Specimen No. 53-4.

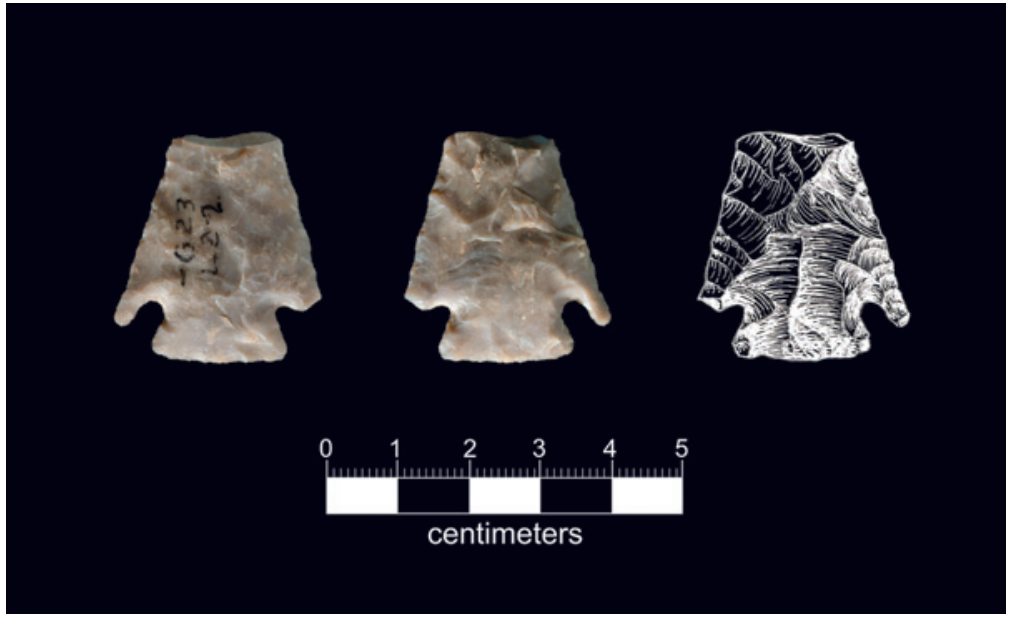

Figure 4-55. Marcos point, Specimen No. 152-1.

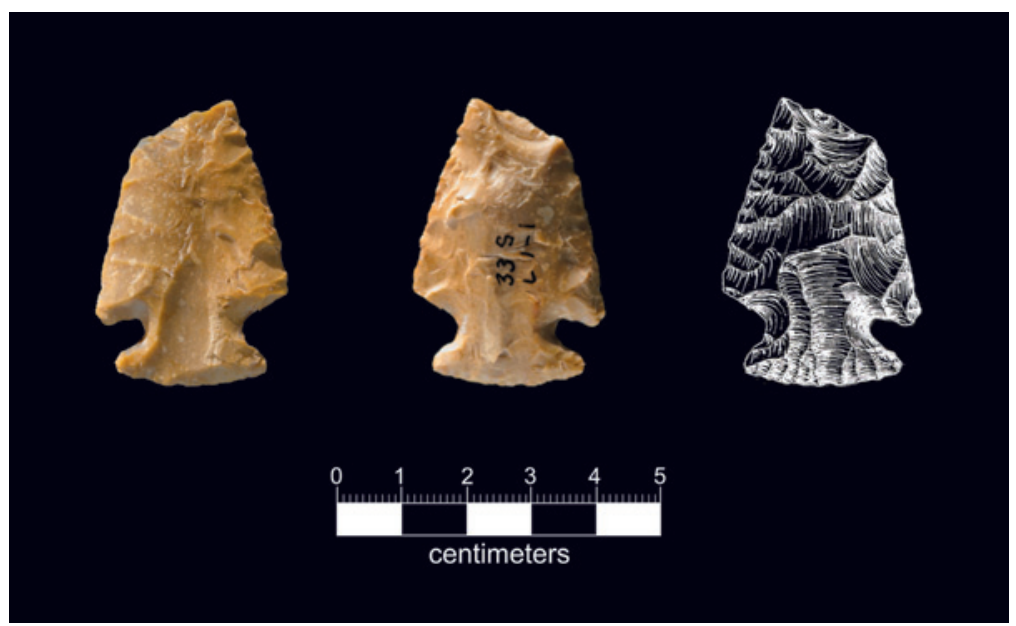

Figure 4-56. Marcos point, Specimen No. 157-1. 


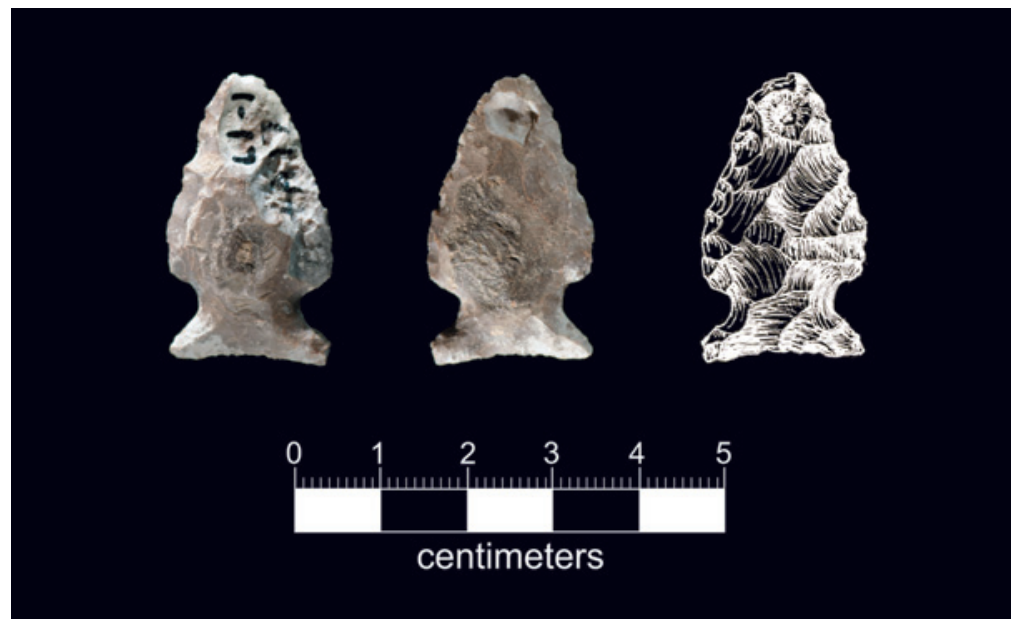

Figure 4-57. Ensor point, Specimen No. 154-2.

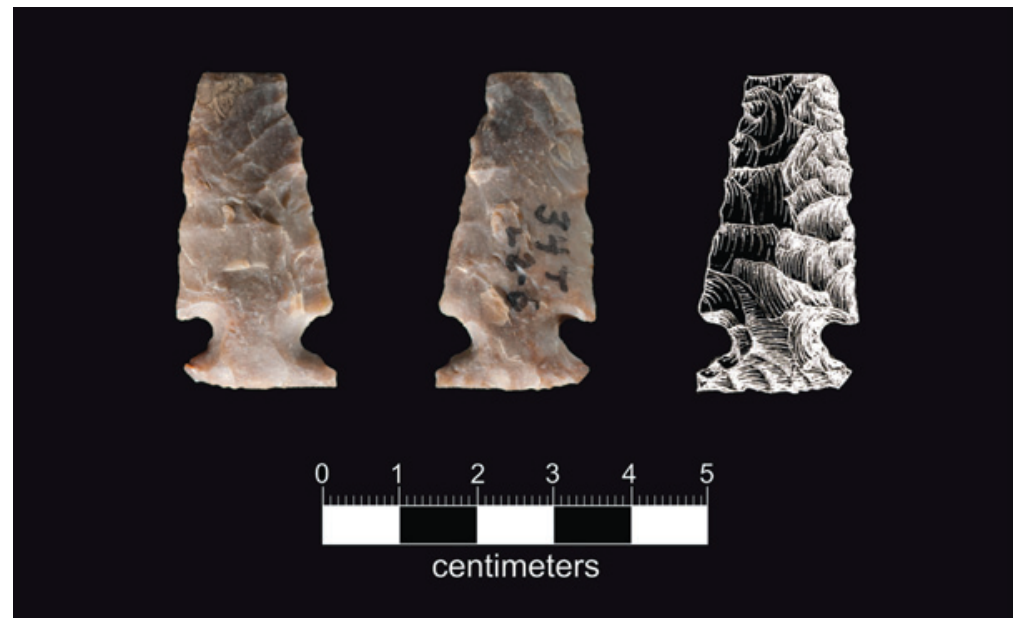

Figure 4-58. Ensor point, Specimen No. 208-1.

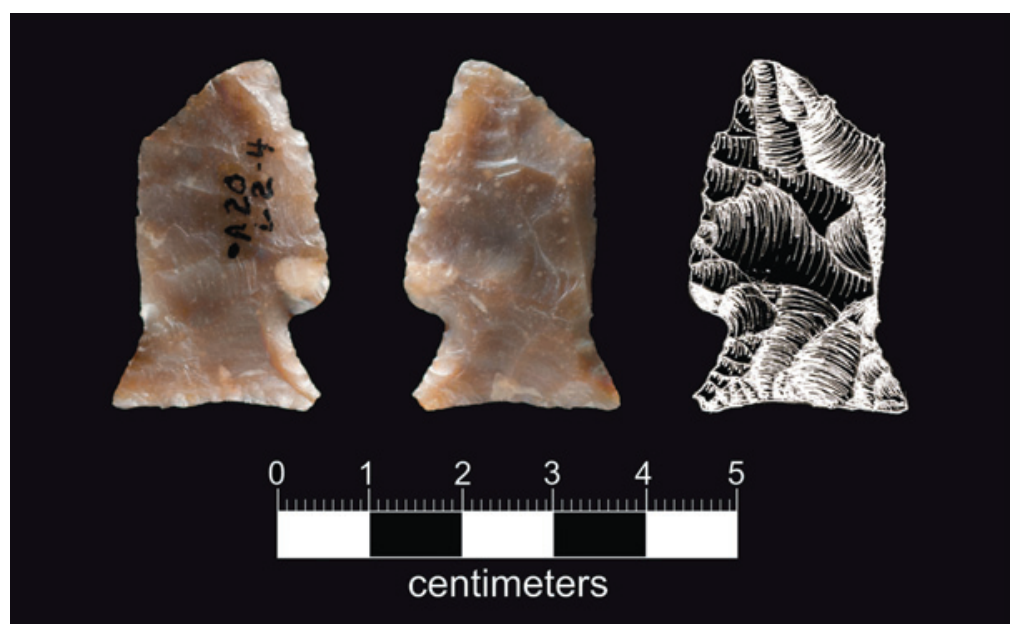

Figure 4-59. Fairland point, Specimen No. 24-3. into the early part of the Historical period. Perdiz arrow points (Figure 4-62) are the most common type from this period, although others are also found in Late Prehistoric assemblages from elsewhere. Some Perdiz styles made of glass have even been recovered from Spanish Mission contexts in San Antonio (Lohse 1999), attesting to the prolonged interaction between native inhabitants and early European colonizers. Other distinctive Toyah tools include four-edge- beveled knives, perhaps used for fileting and processing bison; steep-edge scrapers, some but not all of which were made on coarse blades; large drills; and other tools. After approximately A.D. 1700, it is difficult to recognize Toyah patterns in the material record, and even this late date is in many respects problematic. As the Spanish and French mission era took hold across parts of Texas, the trail of archaeological evidence about native inhabitants eventually disappears. Most aboriginal societies were assimilated, died off from disease or conflict, or left the area. A few 
descendants have returned, but most are gone forever.

\section{The Rest of THE Story}

The overall record of human presence at Spring Lake continues into the present. Because some parts of the story occurred in relatively recent times and have been documented historically (e.g., the millions of Texans who visited the Aquarena Springs water park before it closed in 1996 [Weber 2009], or the early settlement in the 1840s by Edward Burleson [Bousman and Nickels 2003]) these recent chapters of the past are generally far better known than the extensive prehistoric period.

Of all phases of human occupation at this site, however, perhaps the least

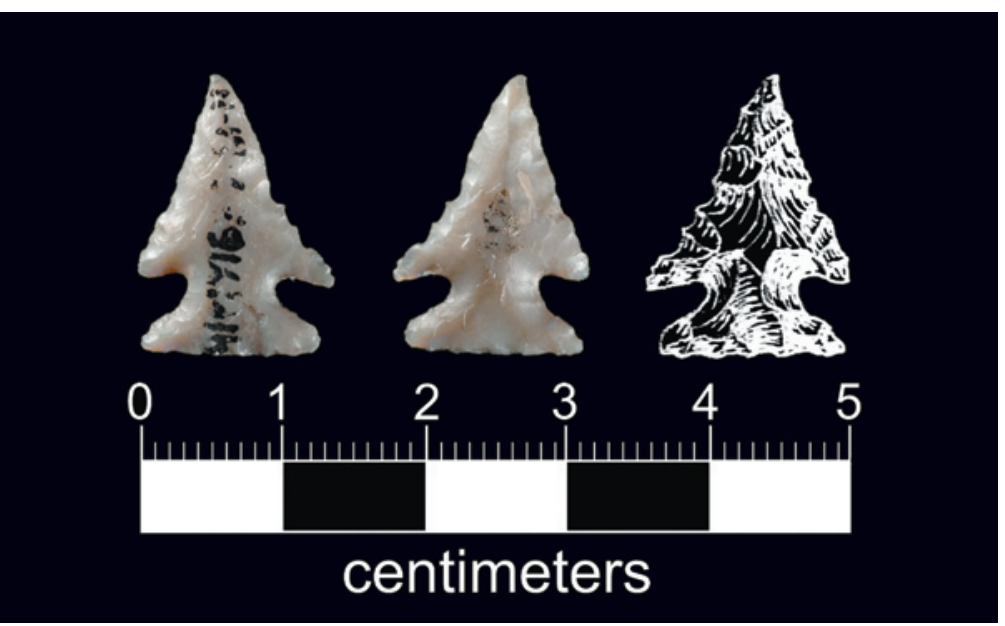

Figure 4-60. Scallorn point, Specimen No. 310-4.

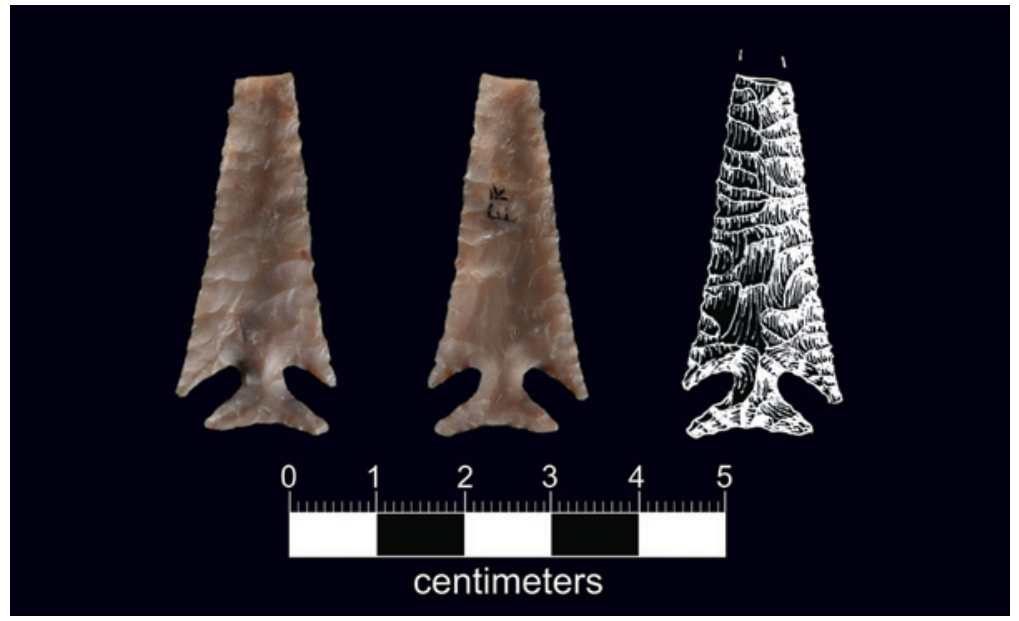

Figure 4-61. Edwards point, Specimen No. 277-48. understood time interval is that of Spanish exploration. According to early research (Bolton 1970), in or around 1755, a collection of Spanish missions were temporarily relocated to the San Marcos area from the San Gabriel River, near present-day Rockdale. Within a short time, the San Marcos missions, their inhabitants, and properties were dispersed either to San Antonio de Béxar, to the area of the present town of Menard on the San Sabá River, or to a newly constructed (but similarly short-lived) mission near New Braunfels. The Spanish returned to the San Marcos area about 50 years later when they established the original San Marcos de Neve townsite. However, within four years this settlement was also abandoned (Horrell 1999). Mission-era arrow points have been recovered in the study area, including one in the mid-1990s from the banks of Spring Lake (Ringstaff 2000), and a fragment of colonial pottery was among the ceramic artifacts found at the Zatopec Site (identified as Black Luster Glaze by Carole Leezer; see 


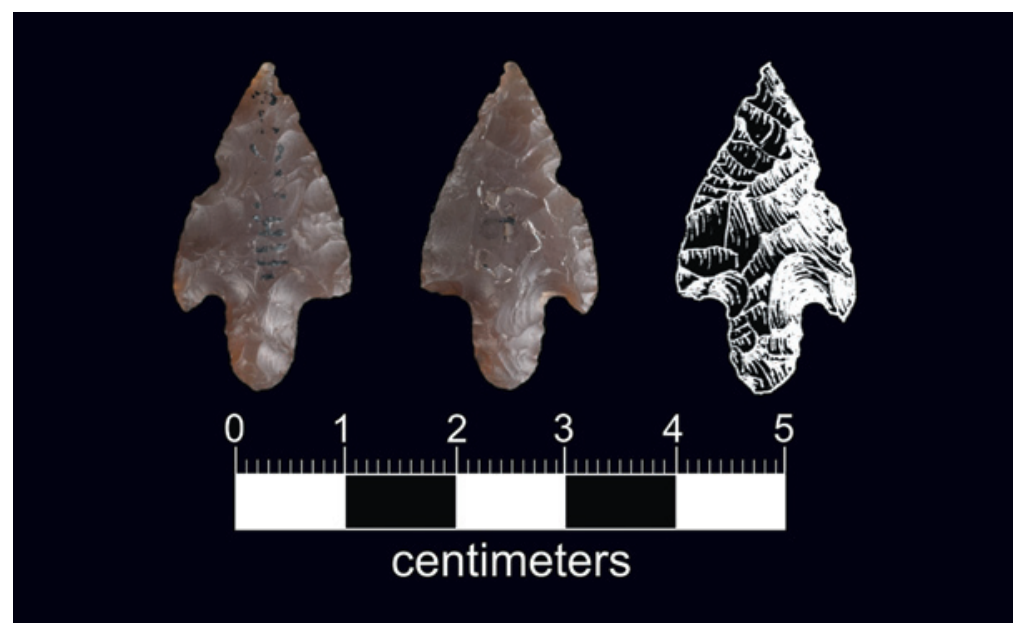

Figure 4-62. Perdiz point, Specimen No. 310-5.
Cecil 2011: Table 6-4), also known as the Wonder World Drive Site, along Purgatory Creek. Apart from this fragmentary evidence, little can presently be said about the material remains of this transformational period. A great deal more research is obviously required in order to fully understand the Spanish period of exploration, colonization, and missionization in the study

area.

By its nature, the historical past can be at least as well understood through archival, documentary, or oral history research as from the analyses of material remains. This is not to say, however, that archaeology has little to contribute to the study of recent time periods at Spring Lake. To the contrary, modern perceptions of a place like Spring Lake, including its cultural value and the significance ascribed to it, change as fresh perspectives emerge and new approaches are developed to investigate and understand the past. It is natural that the recognition and appreciation of the historical and cultural significance of this and other similar sites should evolve with the passage of time. At Spring Lake, archaeologists and public historians can perhaps take the lead in documenting and interpreting the site for the general public. However, it is important for historians and other stakeholders, including interested members of the surrounding community, to also be involved in the ongoing evaluation of this unique place.

Both the University and the City of San Marcos frequently refer to the extensive record of human presence at Spring Lake, celebrating the fact that for millennia people have called the San Marcos Springs their home (San Marcos Horizons City Master Plan 1996:2-7), as, for example in the application of a recent slogan "America's oldest neighborhood" linking the contemporary community with its deep-rooted past. For the expression to retain its meaning, however, all time periods represented in the Spring Lake record of continuous occupation must be valued equally. During the few decades of its comparatively short history as an amusement park (1929-1994), there are likely to have been incalculably more visitors to Aquarena Springs than the total number who came here, even if they could all be added together, during the 13,500 years from Clovis to Late Prehistoric times. The cultural significance of Spring Lake is not based solely on the heritage of and remains left behind by a sometimes idealized, long- 


\section{Chapter 4}

forgotten people. As part of the community's more recent historical legacy, the later era is also worthy of recognition and commemoration.

Historical and cultural significance is not always self-evident in remains of the past, particularly in elements from the more recent past. Although recognition of the value of some of the more recent aspects of the past at Spring Lake can be expected to require time, the process is underway. For example, the Aquarena property, including the University golf course and the remains of the Aquarena Springs amusement park have recently been evaluated for historical significance in compliance with the National Historic Preservation Act (NHPA). The purpose of this study, which was required as part the construction by the City of San Marcos and Texas Department of Transportation of an elevated overpass on Aquarena Springs Drive as it crosses a set of train tracks running through town, was to determine (a) whether any historically significant resources exist in the project area and, if so, (b) whether they would be adversely or negatively impacted by the proposed development. The study (Reynolds and Russo 2012) identified what it called the Aquarena Historic District as eligible for listing to the National Register of Historic Places. In its review of that assessment, the THC concurred with that conclusion (project files dated 20 September, 2012).

In 1966, when the United States Congress passed the NHPA, they wrote "The Congress finds that the historical and cultural foundations of the Nation should be preserved as a living part of our community life ... in order to give a sense of orientation to the American people" (as

cited in Crass 2007:254). The prehistoric and historical records clearly demonstrate that Spring Lake has projected a power of place and provided a sense of orientation to residents of this area for more than 13 millennia. Through these thousands of years, this orientation has evolved from a central place for Native communities closely related to the first occupants of North America sometime late in the last Ice Age, to a struggling mission in the wavering Spanish New World empire, to a frontier homestead and industrial resource, to a popular automobileage travel destination, to a source of pride for the San Marcos community. Today, as a restored natural wonder, Spring Lake serves as a model for natural and cultural resource conservation and management. This unique place promises to continue providing a sense of orientation to both residents and visitors into the next millennium. 
Appendix A. Projectile Points

\begin{tabular}{|c|c|c|c|c|c|c|c|c|c|c|c|}
\hline Type & $\begin{array}{l}\text { Spec. } \\
\text { No. }\end{array}$ & Unit & Level & $\begin{array}{c}\text { Length } \\
(\mathrm{mm})\end{array}$ & $\begin{array}{l}\text { Width } \\
(\mathrm{mm})\end{array}$ & $\begin{array}{c}\text { Thick- } \\
\text { ness } \\
\text { (mm) }\end{array}$ & $\begin{array}{c}\text { Stem } \\
\text { Length } \\
(\mathrm{mm})\end{array}$ & $\begin{array}{c}\text { Stem } \\
\text { Width } \\
(\mathrm{mm})\end{array}$ & $\begin{array}{c}\text { Base } \\
\text { Width } \\
(\mathrm{mm})\end{array}$ & $\begin{array}{l}\text { Break } \\
\text { Type* }\end{array}$ & Notes, Comments \\
\hline \multicolumn{12}{|c|}{ DART POINTS } \\
\hline \multicolumn{12}{|c|}{ Abasolo-like } \\
\hline & 112 & $29-\mathrm{E}$ & 3 & 50 & 25 & 10 & 21 & 25 & 18 & $\mathrm{~A} / \mathrm{D}$ & \\
\hline & $288-33$ & $* *$ & & 62 & 23 & 10 & 29 & 26 & 23 & $\mathrm{X}$ & \\
\hline \multicolumn{12}{|c|}{ Andice } \\
\hline & $49-1$ & $25-\mathrm{F}$ & 4 & $20.5+$ & $18+$ & $6+$ & 21 & 17 & 19.5 & $\mathrm{~B}$ & stem \\
\hline & $99-1$ & $30-\mathrm{G}$ & 2 & $30+$ & $27+$ & $8+$ & 23 & 20 & 15 & $\mathrm{C}$ & base, one barb \\
\hline & $247-1$ & $16-\mathrm{O}$ & surface & $32+$ & 33 & 7 & 23 & 20 & 17 & $\mathrm{~A} / \mathrm{D}$ & base, no barbs \\
\hline \multicolumn{12}{|c|}{ Angostura } \\
\hline & $23-5$ & 26-D & 5 & $34+$ & $20+$ & 7.5 & 23 & $17+$ & 24 & $\mathrm{~A} / \mathrm{B}$ & base, much impact \\
\hline & $27-1$ & 27-D & 5 & $17+$ & $14+$ & 5 & 1 & 22 & 15 & B & base only \\
\hline & $55-1$ & $29-\mathrm{R}$ & 2 & $33+$ & 21 & 5 & - & - & - & $\mathrm{B}$ & no edge dulling \\
\hline & $81-3$ & $31-\mathrm{M}$ & 2 & $42+$ & 26 & 7 & - & - & - & $\mathrm{B}$ & \\
\hline & $108-1$ & $25-\mathrm{C}$ & 5 & $45+$ & $24+$ & 7.5 & 24 & 22 & 14 & $\mathrm{~B}$ & base, damaged edges \\
\hline & $109-1$ & $25-\mathrm{F}$ & 5 & $82+$ & 21 & 8.5 & 24 & 17 & 15 & $\mathrm{~A}$ & tip missing \\
\hline & $288-28$ & $* *$ & $\mathrm{n} / \mathrm{a}$ & $49+$ & 20 & 7 & 27 & 20 & 9 & $\mathrm{~B}$ & $\begin{array}{l}\text { reworked from St. Mary's } \\
\text { Hall? }\end{array}$ \\
\hline & $303-1$ & $19-\mathrm{K}$ & $\mathrm{n} / \mathrm{a}$ & $52+$ & 25 & 7 & 22 & 21 & 17 & $\mathrm{~B} / \mathrm{D}$ & \\
\hline & $306-1$ & $13-\mathrm{K}$ & $\mathrm{n} / \mathrm{a}$ & $23+$ & $18+$ & 6 & 23 & 17 & 18 & $\mathrm{~A} / \mathrm{B}$ & base \\
\hline & 309-12 & $27-\mathrm{F}$ & 5 & $33+$ & $25+$ & 6 & 20 & 20 & 14 & $\mathrm{~B}$ & base \\
\hline
\end{tabular}

* Key to types of breakage patterns:

$\mathrm{X}=$ complete point

$\mathrm{A}=$ direct impact break at the tip, barbs, or base (often appears as a "burin-like" break, though more commonly as a flute-like flake extending from the tip down one face of the point)

$\mathrm{B}=$ snap or bending fracture probably caused by impact on used points or manufacturing mistakes on preforms

$\mathrm{C}=$ burned (usually marked by crazing fractures and pot lid fractures on the artifact)

$\mathrm{D}=$ reworked tip or blade

Points with more than one break were labeled accordingly; e.g. if evidence for both direct impact and snap break was observed, the breakage pattern was coded as A/B.

** Lot No. 288 contains artifacts for which the unit number was eroded and could not be read.

$* * *$ Lot No. 310 contains artifacts from other work at Spring Lake. See end note, Chapter 3. 
Appendix A. Projectile Points, continued

\begin{tabular}{|c|c|c|c|c|c|c|c|c|c|c|c|}
\hline Type & $\begin{array}{c}\text { Spec. } \\
\text { No. }\end{array}$ & Unit & Level & $\begin{array}{c}\text { Length } \\
(\mathrm{mm})\end{array}$ & $\begin{array}{c}\text { Width } \\
(\mathrm{mm})\end{array}$ & $\begin{array}{c}\text { Thick- } \\
\text { ness } \\
(\mathrm{mm})\end{array}$ & $\begin{array}{c}\text { Stem } \\
\text { Length } \\
(\mathrm{mm})\end{array}$ & $\begin{array}{c}\text { Stem } \\
\text { Width } \\
(\mathrm{mm}) \\
\end{array}$ & $\begin{array}{c}\text { Base } \\
\text { Width } \\
(\mathrm{mm})\end{array}$ & $\begin{array}{l}\text { Break } \\
\text { Type* }\end{array}$ & Notes, Comments \\
\hline \multicolumn{12}{|c|}{ Possible Angostura preform } \\
\hline & $42-1$ & $28-\mathrm{B}$ & 3 & 68 & 23 & 11.5 & 20 & 20 & 14 & - & complete \\
\hline & $238-1$ & $12-\mathrm{I}$ & surface & $23+$ & $33+$ & 6 & - & - & - & & slight grinding on edges \\
\hline \multicolumn{12}{|c|}{ Bandy } \\
\hline & $56-1$ & $30-\mathrm{P}$ & 2 & $32+$ & $31+$ & 4,5 & 9 & 13 & 17 & $\mathrm{~A} / \mathrm{D}$ & tip missing \\
\hline & $179-2$ & $22-\mathrm{A}$ & 1 & $34+$ & 28 & 4 & 8 & 11 & 14.5 & B & tip missing \\
\hline & $261-1$ & $35-\mathrm{W}$ & 1 & $23+$ & $17+$ & 4 & 9 & 7 & 16 & $\mathrm{~A}$ & base \\
\hline \multicolumn{12}{|c|}{ Base and Side-Notched } \\
\hline & $16-1$ & $27-\mathrm{C}$ & 3 & $77+$ & 33 & 6 & 12 & 18 & $29.5+$ & $\mathrm{A}$ & very large; $\mathrm{V}$ notch in base \\
\hline \multicolumn{12}{|l|}{ Bell } \\
\hline & $133-1$ & $27-\mathrm{I}$ & 1 & $41+$ & $32+$ & 7 & 15 & 15 & 17.5 & $\mathrm{~A} / \mathrm{B}$ & tip, barb missing \\
\hline \multicolumn{12}{|c|}{ Big Sandy } \\
\hline & $288-24$ & $* *$ & $\mathrm{n} / \mathrm{a}$ & 53 & 39 & 8 & 17 & 22 & 18 & $\mathrm{X}$ & ear missing \\
\hline \multicolumn{12}{|c|}{ Bulverde } \\
\hline & $29-2$ & $29-\mathrm{G}$ & 2 & $66+$ & 28 & 8.5 & 16 & 19 & 16.5 & $\mathrm{~B}$ & tip snapped \\
\hline & $37-3$ & $28-\mathrm{I}$ & 1 & $33+$ & 28 & 8 & 22 & 20 & 27 & $\mathrm{~A} / \mathrm{D}$ & reworked blade \\
\hline & $47-1$ & $28-\mathrm{N}$ & 2 & $38+$ & $26+$ & 7 & 21 & 21 & 19 & $\mathrm{~A} / \mathrm{D}$ & proximal \\
\hline & $85-1$ & $30-\mathrm{K}$ & 1 & $45+$ & 33 & 7 & 18 & 22 & 10 & $\mathrm{~A}$ & tip missing \\
\hline & $136-1$ & $27-\mathrm{K}$ & 2 & $39+$ & 32 & 8.5 & 19 & 17 & 16 & B & bulbar stem \\
\hline
\end{tabular}

* Key to types of breakage patterns:

$\mathrm{X}=$ complete point

A = direct impact break at the tip, barbs, or base (often appears as a "burin-like" break, though more commonly as a flute-like flake extending from the tip down one face of the point)

$\mathrm{B}=$ snap or bending fracture probably caused by impact on used points or manufacturing mistakes on preforms

$\mathrm{C}=$ burned (usually marked by crazing fractures and pot lid fractures on the artifact)

$\mathrm{D}=$ reworked tip or blade

Points with more than one break were labeled accordingly; e.g. if evidence for both direct impact and snap break was observed, the breakage pattern was coded as A/B.

** Lot No. 288 contains artifacts for which the unit number was eroded and could not be read.

$* * *$ Lot No. 310 contains artifacts from other work at Spring Lake. See end note, Chapter 3. 
Appendix A. Projectile Points, continued

\begin{tabular}{|c|c|c|c|c|c|c|c|c|c|c|c|}
\hline Type & $\begin{array}{l}\text { Spec. } \\
\text { No. }\end{array}$ & Unit & Level & $\begin{array}{l}\text { Length } \\
\text { (mm) }\end{array}$ & $\begin{array}{l}\text { Width } \\
\text { (mm) }\end{array}$ & $\begin{array}{l}\text { Thick- } \\
\text { ness } \\
\text { (mm) }\end{array}$ & $\begin{array}{l}\text { Stem } \\
\text { Length } \\
(\mathrm{mm})\end{array}$ & $\begin{array}{l}\text { Stem } \\
\text { Width } \\
\text { (mm) }\end{array}$ & $\begin{array}{l}\text { Base } \\
\text { Width } \\
\text { (mm) }\end{array}$ & $\begin{array}{l}\text { Break } \\
\text { Type* }\end{array}$ & Notes, Comments \\
\hline & $161-1$ & $33-Q$ & 2 & 53 & 34 & 7 & 18 & 20 & 18 & $\mathrm{~A} / \mathrm{D}$ & contracting stem \\
\hline & $174-1$ & & 3 & $47+$ & $31+$ & $7+$ & 18 & 18 & 18 & $\mathrm{~A} / \mathrm{B}$ & base, one barb \\
\hline & $195-1$ & $18-\mathrm{K}$ & surface & $37+$ & 31 & 7 & 16 & 20 & 15 & $\mathrm{~A} / \mathrm{B}$ & base \\
\hline & $199-1$ & $21-\mathrm{F}$ & 1 & $57+$ & 43 & 8 & 21 & 22 & 19 & $\mathrm{~A}$ & base \\
\hline & 209-1 & $34-\mathrm{T}$ & 3 & $43+$ & 39 & 9 & 20 & 22 & 20 & $\mathrm{~B}$ & base \\
\hline & $223-1$ & $24-\mathrm{B}$ & 1 & $39+$ & $31+$ & 9 & 19 & 22 & 20 & A & base \\
\hline & $231-1$ & $11-\mathrm{L}$ & surface & $37+$ & $30+$ & 9 & 17 & 19 & 15 & $\mathrm{~A}$ & base \\
\hline & $233-1$ & $11-\mathrm{N}$ & surface & $39+$ & 24 & 9 & 14 & 16 & 16 & B & base \\
\hline & $243-1$ & $12-\mathrm{O}$ & surface & 43 & 35 & 6 & 18 & 21 & 19 & $\mathrm{~A}$ & base \\
\hline & 275-1 & $38-\mathrm{U}$ & 1 & $29+$ & $\mathrm{n} / \mathrm{a}$ & 7 & 16 & 19 & 17 & $\mathrm{~B} / ?$ & base \\
\hline \multicolumn{12}{|c|}{ Castroville } \\
\hline & $17-1$ & $39-\mathrm{S}$ & 1 & $42.5^{+}$ & 48 & 7 & 13 & 15 & 28 & A & $\begin{array}{l}\text { impact possible one side; tip } \\
\text { missing }\end{array}$ \\
\hline & $18-1$ & $28-\mathrm{O}$ & 1 & $57.5+$ & $40.5+$ & 8 & 21 & 15 & 23.5 & $\mathrm{~A}$ & one barb missing \\
\hline & $22-1$ & $25-B$ & 4 & 59.5 & 41.5 & 8 & 21 & 13 & 22 & - & $\begin{array}{l}\text { complete, very thick and } \\
\text { heavy; reworked and short- } \\
\text { ened }\end{array}$ \\
\hline & $23-1$ & 26-D & 5 & $50+$ & $54+$ & 6 & 27 & $13.5+$ & 29.5 & B & broad, thin \\
\hline & $23-6$ & $26-\mathrm{D}$ & 5 & 49 & $37+$ & 6.5 & 17 & 11,5 & $17+$ & & barbs \\
\hline
\end{tabular}

* Key to types of breakage patterns:

$\mathrm{X}=$ complete point

A = direct impact break at the tip, barbs, or base (often appears as a "burin-like" break, though more commonly as a flute-like flake extending from the tip down one face of the point)

$\mathrm{B}=$ snap or bending fracture probably caused by impact on used points or manufacturing mistakes on preforms

$\mathrm{C}=$ burned (usually marked by crazing fractures and pot lid fractures on the artifact)

$\mathrm{D}=$ reworked tip or blade

Points with more than one break were labeled accordingly; e.g. if evidence for both direct impact and snap break was observed, the breakage pattern was coded as A/B.

** Lot No. 288 contains artifacts for which the unit number was eroded and could not be read. 
Appendix A. Projectile Points, continued

\begin{tabular}{|c|c|c|c|c|c|c|c|c|c|c|c|}
\hline Type & $\begin{array}{c}\text { Spec. } \\
\text { No. }\end{array}$ & Unit & Level & $\begin{array}{c}\text { Length } \\
\text { (mm) }\end{array}$ & $\begin{array}{l}\text { Width } \\
\text { (mm) }\end{array}$ & $\begin{array}{c}\text { Thick- } \\
\text { ness } \\
\text { (mm) }\end{array}$ & $\begin{array}{c}\text { Stem } \\
\text { Length } \\
(\mathrm{mm})\end{array}$ & $\begin{array}{c}\text { Stem } \\
\text { Width } \\
\text { (mm) }\end{array}$ & $\begin{array}{c}\text { Base } \\
\text { Width } \\
(\mathrm{mm})\end{array}$ & $\begin{array}{l}\text { Break } \\
\text { Type* }\end{array}$ & Notes, Comments \\
\hline & $76-1$ & $31-\mathrm{F}$ & & $38+$ & $34+$ & 9 & 12.5 & 21 & 27 & B & \\
\hline & $176-2$ & $22-\mathrm{B}$ & 2 & $42+$ & 44 & 8 & 16 & 22 & 24 & $\mathrm{~B}$ & \\
\hline & $183-1$ & $20-\mathrm{I}$ & surface & 47 & $34+$ & 7 & 13 & 23 & 25 & $\mathrm{D}$ & \\
\hline & $185-1$ & $20-\mathrm{O}$ & 1 & $37+$ & $30+$ & $6+$ & 14 & 26 & 29 & $\mathrm{C}$ & \\
\hline & $246-1$ & $16-\mathrm{F}$ & surface & $43+$ & $38+$ & 8 & $10+$ & 22 & $\mathrm{n} / \mathrm{a}$ & $\mathrm{A} ?$ & \\
\hline & $264-1$ & $35-\mathrm{Y}$ & 1 & $51+$ & 33 & 7 & 16 & 21 & 25 & $\mathrm{~A} / \mathrm{D}$ & tip; barbs missing \\
\hline & $288-23$ & $* *$ & & 44 & $32+$ & 6 & 13 & 20 & 24 & $?$ & barb missing \\
\hline & $309-13$ & $?$ & 3 & $62+$ & 52 & 6 & 15 & 25 & 29 & A & tip missing \\
\hline \multicolumn{12}{|c|}{ Clovis } \\
\hline & $77-2$ & $31-\mathrm{F}$ & 3 & $25+$ & 29 & 7 & & 29.5 & 26 & $\mathrm{~B}$ & base; one side fluted \\
\hline & $310-1$ & $* * *$ & $\mathrm{n} / \mathrm{a}$ & 42 & 30 & 7 & 22 & 29 & 24 & $\mathrm{D}$ & see description in Chapter 3 \\
\hline & $310-2$ & $* * *$ & $\mathrm{n} / \mathrm{a}$ & 105 & 32 & 9 & 23 & 31 & 29 & $\mathrm{n} / \mathrm{a}$ & see description in Chapter 3 \\
\hline \multicolumn{12}{|c|}{ Possible Clovis Base } \\
\hline & 13-1 & 38-T & 1 & $31+$ & $21+$ & $5+$ & & & & $\mathrm{B}$ & fluted on one face; trowel hit \\
\hline \multicolumn{12}{|l|}{ Darl } \\
\hline & 80-1 & $31-\mathrm{C}$ & & $20+$ & $19+$ & $4+$ & 12 & 14 & 15 & $\mathrm{C}$ & base; heavily burned \\
\hline \multicolumn{12}{|c|}{ Early Barbed } \\
\hline & 59-1 & 26-B & 4 & 42 & $31+$ & 7 & $15+$ & 16 & $14+$ & $\mathrm{X}$ & barb missing \\
\hline \multicolumn{12}{|c|}{ Early Triangular } \\
\hline & $15-1$ & 31-P & 1 & 56 & 32 & 6 & & & 32 & A & beveled to left, base damaged \\
\hline \multicolumn{12}{|c|}{$\begin{array}{l}\text { * Key to types of breakage patterns: } \\
\mathrm{X}=\text { complete point } \\
\mathrm{A} \text { = direct impact break at the tip, barbs, or base (often appears as a "burin-like" break, though more commonly a } \\
\text { the point) } \\
\mathrm{B} \text { = snap or bending fracture probably caused by impact on used points or manufacturing mistakes on preforms } \\
\mathrm{C} \text { = burned (usually marked by crazing fractures and pot lid fractures on the artifact) } \\
\text { D = reworked tip or blade } \\
\text { Points with more than one break were labeled accordingly; e.g. if evidence for both direct impact and snap break }\end{array}$} \\
\hline
\end{tabular}


Appendix A. Projectile Points, continued

\begin{tabular}{|c|c|c|c|c|c|c|c|c|c|c|c|}
\hline Type & $\begin{array}{l}\text { Spec. } \\
\text { No. }\end{array}$ & Unit & Level & $\begin{array}{l}\text { Length } \\
\text { (mm) }\end{array}$ & $\begin{array}{l}\text { Width } \\
\text { (mm) }\end{array}$ & $\begin{array}{l}\text { Thick- } \\
\text { ness } \\
\text { (mm) }\end{array}$ & $\begin{array}{c}\text { Stem } \\
\text { Length } \\
\text { (mm) }\end{array}$ & $\begin{array}{l}\text { Stem } \\
\text { Width } \\
(\mathrm{mm})\end{array}$ & $\begin{array}{c}\text { Base } \\
\text { Width } \\
(\mathrm{mm})\end{array}$ & $\begin{array}{l}\text { Break } \\
\text { Type* }\end{array}$ & Notes, Comments \\
\hline & $35-2$ & $28-\mathrm{R}$ & 1 & $33+$ & 34.5 & 5 & - & - & 34 & $\mathrm{~A}$ & ET technology \\
\hline & $63-1$ & $26-\mathrm{F}$ & 4 & $39+$ & $43.5+$ & $7.5^{+}$ & & - & 43.5 & $\mathrm{~B}$ & prox \\
\hline & $89-1$ & $30-\mathrm{S}$ & 1 & $55+$ & 35 & 6.5 & - & & $33+$ & $\mathrm{A}$ & $\begin{array}{l}\text { parallel oblique flaking; alt } \\
\text { bevel }\end{array}$ \\
\hline & $90-2$ & $30-\mathrm{U}$ & 1 & $18+$ & 30 & 6.5 & - & & - & $\mathrm{A}$ & $\begin{array}{l}\text { parallel oblique flaking; alt } \\
\text { bevel }\end{array}$ \\
\hline & $120-1$ & $29-\mathrm{F}$ & 4 & $25+$ & 37 & 5 & & & 37 & $\mathrm{~B}$ & ET base \\
\hline & $128-1$ & $27-\mathrm{E}$ & 3 & $25+$ & $25+$ & $5.5+$ & & & & $\mathrm{C}$ & reworked Early Triangular \\
\hline & $131-2$ & $27-\mathrm{C}$ & 4 & $36+$ & $29+$ & 7 & & & & $\mathrm{~A}$ & medial frag of ET \\
\hline & $156-2$ & $17-\mathrm{N}$ & 2 & $39+$ & 29 & 8 & & & 28 & $\mathrm{~B}$ & ET \\
\hline & $168-1$ & 13-J & $\begin{array}{l}\text { sur- } \\
\text { face }\end{array}$ & $28+$ & 31 & 7 & & & 30 & $\mathrm{C}$ & small ET \\
\hline & $169-1$ & $13-\mathrm{Q}$ & 1 & $43+$ & $32+$ & 8 & & & 31 & $\mathrm{~A} / \mathrm{C}$ & strongly beveled to right \\
\hline & $180-1$ & $22-\mathrm{D}$ & 1 & 45 & 32 & 10 & & & 32 & A & thick reworked base \\
\hline & $240-1$ & $12-\mathrm{K}$ & $1(3)$ & 54 & 40 & 8 & & & & $\mathrm{D}$ & \\
\hline & $250-1$ & $15-\mathrm{F}$ & surface & 50 & 32 & 6 & - & & 32 & & edge beveled left \\
\hline & $288-34$ & $* *$ & & $28+$ & 33 & 5 & & & & B & base \\
\hline & $288-4$ & $* *$ & & $53+$ & $30+$ & 10 & & & & & reworked but failed \\
\hline & $288-53$ & $* *$ & & $35+$ & $34+$ & 7 & & & & & base fragment \\
\hline \multicolumn{12}{|c|}{ Ensor } \\
\hline & $25-4$ & $28-\mathrm{E}$ & 5 & $30+$ & $20.5+$ & $4+$ & 10 & $11+$ & $21+$ & $\mathrm{C}$ & heavily burned \\
\hline \multicolumn{12}{|c|}{$\begin{array}{l}\text { * Key to types of breakage patterns: } \\
\mathrm{X}=\text { complete point } \\
\mathrm{A}=\text { direct impact break at the tip, barbs, or base (often appears as a "burin-like" break, though more commonly as a flute-like flake extending from the tip down one face of } \\
\text { the point) } \\
\mathrm{B}=\text { snap or bending fracture probably caused by impact on used points or manufacturing mistakes on preforms } \\
\mathrm{C}=\text { burned (usually marked by crazing fractures and pot lid fractures on the artifact) } \\
\mathrm{D}=\text { reworked tip or blade } \\
\text { Points with more than one break were labeled accordingly; e.g. if evidence for both direct impact and snap break was observed, the breakage pattern was coded as A/B. } \\
* * * \text { Lot No. } 288 \text { contains artifacts for which the unit number was eroded and could not be read. } \\
* * * * \text { Lot No. } 310 \text { contains artifacts from other work at Spring Lake. See end note, Chapter } 3 .\end{array}$} \\
\hline
\end{tabular}


Appendix A. Projectile Points, continued

\begin{tabular}{|c|c|c|c|c|c|c|c|c|c|c|c|}
\hline Type & $\begin{array}{l}\text { Spec. } \\
\text { No. }\end{array}$ & Unit & Level & $\begin{array}{l}\text { Length } \\
(\mathrm{mm})\end{array}$ & $\begin{array}{l}\text { Width } \\
\text { (mm) }\end{array}$ & $\begin{array}{c}\text { Thick- } \\
\text { ness } \\
\text { (mm) }\end{array}$ & $\begin{array}{c}\text { Stem } \\
\text { Length } \\
(\mathrm{mm})\end{array}$ & $\begin{array}{c}\text { Stem } \\
\text { Width } \\
\text { (mm) }\end{array}$ & $\begin{array}{c}\text { Base } \\
\text { Width } \\
\text { (mm) }\end{array}$ & $\begin{array}{l}\text { Break } \\
\text { Type* }\end{array}$ & Notes, Comments \\
\hline & $154-2$ & $17-\mathrm{A}$ & 1 & 33 & 18 & 7 & 10 & 12.5 & 19 & $\mathrm{C}$ & Ensor; burned base \\
\hline & $156-1$ & $17-\mathrm{N}$ & surface & $22+$ & $28+$ & 5 & 11 & $21+$ & $21+$ & $\mathrm{B}$ & $\begin{array}{l}\text { short and wide stem; beveled } \\
\text { on one edge }\end{array}$ \\
\hline & $158-1$ & $33-\mathrm{R}$ & 1 & $46+$ & 29 & 5 & 10 & & 30 & A & wide base form \\
\hline & $208-1$ & $34-\mathrm{T}$ & 2 & $42+$ & 20 & 5 & 10 & 12 & 20 & $\mathrm{~B}$ & \\
\hline & $235-2$ & $10-\mathrm{N}$ & surface & $49+$ & 26 & 9 & 10 & 20 & 24 & $\mathrm{~A}$ & \\
\hline & $290-1$ & $32-\mathrm{T}$ & 2 & 29 & 22 & 7 & 7 & 15 & 22 & $\mathrm{~A} / \mathrm{B}$ & tip missing \\
\hline & $294-1$ & $20-\mathrm{C}$ & 3 & $34+$ & 23 & 6 & 10 & 14 & 23 & $\mathrm{~B}$ & tip missing \\
\hline \multicolumn{12}{|c|}{ Evant } \\
\hline & $141-1$ & $27-\mathrm{F}$ & 5 & $42+$ & 21 & 7 & 15 & 16 & 17 & A & distal impact \\
\hline & $141-2$ & $27-\mathrm{F}$ & 5 & $49+$ & 23 & 7.5 & 18 & 17 & 16 & A & Evant prox \\
\hline & $144-1$ & $27-\mathrm{B}$ & 4 & $32+$ & $25+$ & 6.5 & 20 & & 18 & $\mathrm{C}$ & $\begin{array}{l}\text { proximal frag of Nolan or } \\
\text { Evant? }\end{array}$ \\
\hline & $164-1$ & $33-\mathrm{Y}$ & 2 & $55+$ & 27 & 7 & 17 & 19 & 18 & $\mathrm{C}$ & tip missing \\
\hline & $170-1$ & $13-\mathrm{A}$ & surface & 38 & 19 & 7.5 & 15 & 16 & 17 & $\mathrm{X} / \mathrm{D}$ & reworked blade \\
\hline & $184-1$ & $20-\mathrm{I}$ & 1 & $47+$ & 27 & 9 & 17 & 18 & 18 & $\mathrm{~A}$ & proximal \\
\hline & $210-1$ & $34-\mathrm{T}$ & $?$ & $19+$ & - & 7 & 19 & 16 & 15 & $\mathrm{~A}$ & base \\
\hline & 213-1 & $28-\mathrm{H}$ & 4 & $25+$ & $25+$ & 7 & 18 & 16 & 13 & B & \\
\hline & 255-1 & $33-\mathrm{P}$ & 1 & 60 & 22 & 9 & 13 & 12 & 13 & & complete \\
\hline
\end{tabular}

* Key to types of breakage patterns:

$\mathrm{X}=$ complete point

$\mathrm{A}=$ direct impact break at the tip, barbs, or base (often appears as a "burin-like" break, though more commonly as a flute-like flake extending from the tip down one face of the point)

$\mathrm{B}=$ snap or bending fracture probably caused by impact on used points or manufacturing mistakes on preforms

$\mathrm{C}=$ burned (usually marked by crazing fractures and pot lid fractures on the artifact)

$\mathrm{D}=$ reworked tip or blade

Points with more than one break were labeled accordingly; e.g. if evidence for both direct impact and snap break was observed, the breakage pattern was coded as A/B.

** Lot No. 288 contains artifacts for which the unit number was eroded and could not be read.

*** Lot No. 310 contains artifacts from other work at Spring Lake. See end note, Chapter 3. 
Appendix A. Projectile Points, continued

\begin{tabular}{|c|c|c|c|c|c|c|c|c|c|c|c|}
\hline Type & $\begin{array}{l}\text { Spec. } \\
\text { No. }\end{array}$ & Unit & Level & $\begin{array}{l}\text { Length } \\
(\mathrm{mm})\end{array}$ & $\begin{array}{l}\text { Width } \\
\text { (mm) }\end{array}$ & $\begin{array}{l}\text { Thick- } \\
\text { ness } \\
(\mathrm{mm})\end{array}$ & $\begin{array}{l}\text { Stem } \\
\text { Length } \\
\text { (mm) }\end{array}$ & $\begin{array}{l}\text { Stem } \\
\text { Width } \\
(\mathrm{mm})\end{array}$ & $\begin{array}{c}\text { Base } \\
\text { Width } \\
(\mathrm{mm})\end{array}$ & $\begin{array}{l}\text { Break } \\
\text { Type* }\end{array}$ & Notes, Comments \\
\hline & $288-5$ & $* *$ & & $64+$ & 34 & 8 & 16 & 17 & 18 & $\mathrm{~A} / \mathrm{B}$ & tip missing \\
\hline \multicolumn{12}{|c|}{ Fairland } \\
\hline & $24-3$ & $20-\mathrm{A}$ & 2 & $38+$ & $24+$ & 4.5 & 16 & 11.5 & 23 & $\mathrm{C}$ & thin; translucent tan \\
\hline & $29-3$ & $29-\mathrm{G}$ & 2 & $50.5+$ & $28+$ & 5 & 11 & 14 & 19 & edge & stream rolled \\
\hline & $299-1$ & $34-\mathrm{U}$ & 1 & 34 & 23 & 23 & 10 & 14 & 19 & $\mathrm{D}$ & barb missing \\
\hline \multicolumn{12}{|c|}{ Folsom } \\
\hline & $119-2$ & $29-\mathrm{G}$ & $3(\mathrm{~A})$ & $34+$ & 21 & 5 & & & & $\mathrm{~B}$ & distal 2/3 of Folsom \\
\hline \multicolumn{12}{|c|}{ Possible Folsom Base } \\
\hline & $201-3$ & 21-C & 2 & $25+$ & 28 & 5 & & & 27 & $\mathrm{C}$ & no nipple \\
\hline \multicolumn{12}{|l|}{ Frio } \\
\hline & $30-1$ & $27-\mathrm{H}$ & 4 & $25+$ & $25+$ & $5+$ & 9.5 & 19 & 21 & $\mathrm{C}$ & heavily burned; potlids \\
\hline & $102-3$ & $30-\mathrm{G}$ & 5 & $45+$ & $20+$ & 6.5 & & & & $\mathrm{~A}$ & Frio point \\
\hline & $245-2$ & $16-\mathrm{A}$ & 2 & $37+$ & 27 & 5 & 10 & 16 & 19 & $\mathrm{~B}$ & tip missing \\
\hline \multicolumn{12}{|c|}{ Golondrina } \\
\hline & $91-2$ & $30-\mathrm{I}$ & 3 & $56+$ & 22 & 7 & $23+$ & 22.5 & $24+$ & $\mathrm{A}$ & typical flared; alt bev right \\
\hline & $309-14$ & $29(?)$ & 6 & $35+$ & $23+$ & 7 & $29+$ & 28 & 30 & $\mathrm{~B}$ & $\begin{array}{l}\text { heavily ground stem; beveled } \\
\text { left }\end{array}$ \\
\hline \multicolumn{12}{|c|}{$\begin{array}{l}\text { * Key to types of breakage patterns: } \\
\mathrm{X}=\text { complete point } \\
\mathrm{A}=\text { direct impact break at the tip, barbs, or base (often appears as a "burin-like" break, though more commonly as a flute-like flake extending from the tip down one face of } \\
\text { the point) } \\
\mathrm{B}=\text { snap or bending fracture probably caused by impact on used points or manufacturing mistakes on preforms } \\
\mathrm{C}=\text { burned (usually marked by crazing fractures and pot lid fractures on the artifact) } \\
\mathrm{D}=\text { reworked tip or blade } \\
\text { Points with more than one break were labeled accordingly; e.g. if evidence for both direct impact and snap break was observed, the breakage pattern was coded as A/B. }\end{array}$} \\
\hline
\end{tabular}


Appendix A. Projectile Points, continued

\begin{tabular}{|c|c|c|c|c|c|c|c|c|c|c|c|}
\hline Type & $\begin{array}{l}\text { Spec. } \\
\text { No. }\end{array}$ & Unit & Level & $\begin{array}{c}\text { Length } \\
(\mathrm{mm})\end{array}$ & $\begin{array}{l}\text { Width } \\
(\mathrm{mm})\end{array}$ & $\begin{array}{c}\text { Thick- } \\
\text { ness } \\
(\mathrm{mm})\end{array}$ & $\begin{array}{l}\text { Stem } \\
\text { Length } \\
(\mathrm{mm})\end{array}$ & $\begin{array}{l}\text { Stem } \\
\text { Width } \\
(\mathrm{mm})\end{array}$ & $\begin{array}{l}\text { Base } \\
\text { Width } \\
\text { (mm) }\end{array}$ & $\begin{array}{l}\text { Break } \\
\text { Type* }\end{array}$ & Notes, Comments \\
\hline & $310-7$ & $* * *$ & $\mathrm{n} / \mathrm{a}$ & $54+$ & 26 & 6 & 21 & 26 & $17+$ & $\mathrm{A} / \mathrm{B}$ & $\begin{array}{l}\text { contracting stem, beveled } \\
\text { right }\end{array}$ \\
\hline \multicolumn{12}{|c|}{ Hoxie } \\
\hline & $32-1$ & $26-\mathrm{B}$ & 6 & 61 & 22.5 & 8 & 15 & 18 & 17 & $\mathrm{D}$ & dulled stem edges \\
\hline \multicolumn{12}{|l|}{ Jetta } \\
\hline & $39-5$ & $28-\mathrm{C}$ & 5 & $42+$ & 34 & 8 & 15 & 15 & 15 & $\mathrm{~A}$ & $\begin{array}{l}\text { tip missing, blade twist to } \\
\text { left }\end{array}$ \\
\hline & $288-1$ & $* *$ & & $54+$ & 39 & 9 & 15 & 21 & - & A & \\
\hline & $288-41$ & $* *$ & & 50 & 39 & 8 & 15 & 20 & & $\mathrm{~A}$ & twist to right \\
\hline \multicolumn{12}{|c|}{ Laguna } \\
\hline & $33-1$ & $28-\mathrm{F}$ & 4 & 70 & $33+$ & 7 & 14 & 15 & 17 & B & barbs snapped \\
\hline & $159-2$ & $33-\mathrm{T}$ & 1 & $56+$ & $37+$ & 7 & 14 & 16 & 16 & B & \\
\hline \multicolumn{12}{|c|}{ Lange } \\
\hline & $23-3$ & $26-\mathrm{D}$ & 5 & & $34.5+$ & 25 & 5 & 12 & 22 & $\mathrm{~A} / \mathrm{B}$ & \\
\hline & $37-1$ & 28 -I & 1 & $49.5+$ & 32 & 7 & 14 & 18 & 19 & B & proximal \\
\hline & $141-4$ & $27-\mathrm{F}$ & 5 & $49+$ & $28+$ & 6 & 14 & 17 & 20.5 & B & Lange, tip broken \\
\hline & $154-1$ & 17-A & 1 & $46+$ & $39+$ & 7 & 18 & 19.5 & 22 & B & base \\
\hline & $165-1$ & $33-\mathrm{V}$ & 1 & 46 & 32 & 6 & 14 & 17 & 18 & B & \\
\hline & $206-1$ & $34-\mathrm{V}$ & 2 & $83+$ & 32 & 6 & 14 & 20 & 22 & B & \\
\hline & 268-1 & $36-\mathrm{W}$ & 1 & $53+$ & 30 & 8 & 16 & 18 & 18 & B & \\
\hline & 280-1 & $39-\mathrm{V}$ & 2 & $29+$ & $\mathrm{n} / \mathrm{a}$ & 7 & 12 & 10 & 9 & $\mathrm{C}$ & base \\
\hline
\end{tabular}

* Key to types of breakage patterns:

$\mathrm{X}=$ complete point

$\mathrm{A}=$ direct impact break at the tip, barbs, or base (often appears as a "burin-like" break, though more commonly as a flute-like flake extending from the tip down one face of the point)

$\mathrm{B}=$ snap or bending fracture probably caused by impact on used points or manufacturing mistakes on preforms

$\mathrm{C}=$ burned (usually marked by crazing fractures and pot lid fractures on the artifact)

$\mathrm{D}=$ reworked tip or blade

Points with more than one break were labeled accordingly; e.g. if evidence for both direct impact and snap break was observed, the breakage pattern was coded as A/B.

** Lot No. 288 contains artifacts for which the unit number was eroded and could not be read.

*** Lot No. 310 contains artifacts from other work at Spring Lake. See end note, Chapter 3. 
Appendix A. Projectile Points, continued

\begin{tabular}{|c|c|c|c|c|c|c|c|c|c|c|c|}
\hline Type & $\begin{array}{l}\text { Spec. } \\
\text { No. }\end{array}$ & Unit & Level & $\begin{array}{c}\text { Length } \\
(\mathrm{mm})\end{array}$ & $\begin{array}{l}\text { Width } \\
(\mathrm{mm})\end{array}$ & $\begin{array}{c}\text { Thick- } \\
\text { ness } \\
(\mathrm{mm})\end{array}$ & $\begin{array}{c}\text { Stem } \\
\text { Length } \\
(\mathrm{mm})\end{array}$ & $\begin{array}{l}\text { Stem } \\
\text { Width } \\
(\mathrm{mm})\end{array}$ & $\begin{array}{c}\text { Base } \\
\text { Width } \\
(\mathrm{mm})\end{array}$ & $\begin{array}{l}\text { Break } \\
\text { Type* }\end{array}$ & Notes, Comments \\
\hline & $288-27$ & $* *$ & & 55 & 26 & 8 & 13 & 16 & 20 & $\mathrm{X}$ & $\begin{array}{l}\text { expanding stem, concave } \\
\text { base }\end{array}$ \\
\hline \multicolumn{12}{|c|}{ Langtry } \\
\hline & 6-1 & $23-\mathrm{C}$ & 1 & $77+$ & 31 & 8 & 20 & 14 & 11 & $\mathrm{~B}$ & very tip missing \\
\hline & $9-1$ & $27-G$ & 4 & $45^{+}$ & $25.5+$ & 4.5 & 17 & 12 & 10 & $\mathrm{~A}$ & tip both barbs missing \\
\hline & $164-2$ & $33-\mathrm{Y}$ & 2 & $53+$ & 24 & 7 & 11 & 12 & 12 & $\mathrm{~B}$ & possibly Langtry \\
\hline \multicolumn{12}{|c|}{ Marcos } \\
\hline & $35-1$ & $28-\mathrm{R}$ & 1 & $34+$ & $33+$ & 7 & 11.5 & 14 & $19.5^{+}$ & $\mathrm{B}$ & $\begin{array}{l}\text { looks like Maros but stem } \\
\text { edges are dinged and give a } \\
\text { "changed" appearance }\end{array}$ \\
\hline & $53-4$ & $29-\mathrm{H}$ & 5 & $41+$ & $33+$ & 7 & 9 & 19 & 22 & $\mathrm{~B}$ & tip gone \\
\hline & 89-3 & $30-\mathrm{S}$ & 1 & $22+$ & $30+$ & 7.5 & 11.5 & 18.5 & 23.5 & B & base only, barb missing \\
\hline & $109-2$ & $25-\mathrm{F}$ & 5 & $36+$ & 29 & 5 & 11 & 18 & 20 & $\mathrm{~A} / \mathrm{D}$ & $\begin{array}{l}\text { base indention not inten- } \\
\text { tional }\end{array}$ \\
\hline & $113-1$ & $29-\mathrm{C}$ & 1 & $38+$ & $34+$ & 8.5 & 13 & 19 & 26 & $\mathrm{~B}$ & thick, heavy \\
\hline & $133-2$ & $27-\mathrm{I}$ & 1 & $40+$ & 28.5 & 5 & 8 & 15 & 20 & $\mathrm{~B}$ & tip, barb missing \\
\hline & $152-1$ & $23-G$ & 2 & $33+$ & $30+$ & 5 & 8 & 16 & 19 & $\mathrm{~B}$ & Marcos \\
\hline & $157-1$ & $33-\mathrm{S}$ & 1 & $45+$ & $31+$ & 5 & 13 & 16 & 24 & $\mathrm{~B}$ & large \\
\hline & $181-1$ & $20-\mathrm{B}$ & 1 & $51+$ & 26 & 8 & 11 & 16 & 19 & $\mathrm{~A}$ & Marcos with barbs removed \\
\hline & $196-1$ & $18-\mathrm{L}$ & surface & $33+$ & 31 & 6 & 11 & 7 & 20 & $\mathrm{~B}$ & base \\
\hline
\end{tabular}

* Key to types of breakage patterns:

$\mathrm{X}=$ complete point

$\mathrm{A}=$ direct impact break at the tip, barbs, or base (often appears as a "burin-like" break, though more commonly as a flute-like flake extending from the tip down one face of

the point)

$\mathrm{B}=$ snap or bending fracture probably caused by impact on used points or manufacturing mistakes on preforms

$\mathrm{C}=$ burned (usually marked by crazing fractures and pot lid fractures on the artifact)

$\mathrm{D}=$ reworked tip or blade

Points with more than one break were labeled accordingly; e.g. if evidence for both direct impact and snap break was observed, the breakage pattern was coded as A/B.

** Lot No. 288 contains artifacts for which the unit number was eroded and could not be read.

$* * *$ Lot No. 310 contains artifacts from other work at Spring Lake. See end note, Chapter 3. 
Appendix A. Projectile Points, continued

\begin{tabular}{|c|c|c|c|c|c|c|c|c|c|c|c|}
\hline Type & $\begin{array}{c}\text { Spec. } \\
\text { No. }\end{array}$ & Unit & Level & $\begin{array}{l}\text { Length } \\
(\mathrm{mm})\end{array}$ & $\begin{array}{l}\text { Width } \\
\text { (mm) }\end{array}$ & $\begin{array}{c}\text { Thick- } \\
\text { ness } \\
\text { (mm) }\end{array}$ & $\begin{array}{c}\text { Stem } \\
\text { Length } \\
(\mathrm{mm})\end{array}$ & $\begin{array}{c}\text { Stem } \\
\text { Width } \\
\text { (mm) }\end{array}$ & $\begin{array}{c}\text { Base } \\
\text { Width } \\
\text { (mm) }\end{array}$ & $\begin{array}{l}\text { Break } \\
\text { Type* }\end{array}$ & Notes, Comments \\
\hline & $244-1$ & $16-\mathrm{A}$ & 1 & $43+$ & $31+$ & 6 & 15 & 15 & 20 & $\mathrm{~A}$ & tip missing; \\
\hline & $252-2$ & $15-\mathrm{K}$ & surface & 42 & 25 & 5 & 8 & 17 & 19 & $\mathrm{D}$ & complete \\
\hline & $260-1$ & $35-\mathrm{U}$ & 2 & $54+$ & 30 & 9 & 10 & 16 & 21 & $\mathrm{~B}$ & tip missing; straight base \\
\hline & $288-20$ & $* *$ & & $33+$ & $35+$ & $6+$ & 10 & 20 & $23+$ & $\mathrm{C}$ & badly burned \\
\hline & $310-6$ & $* * *$ & & 36 & 25 & 6 & 10 & 15 & 20 & & complete \\
\hline \multicolumn{12}{|c|}{ Marshall } \\
\hline & $24-2$ & $20-\mathrm{A}$ & 2 & $37+$ & 36 & 7 & & & & & \\
\hline & $85-2$ & $30-K$ & 1 & $31+$ & $35+$ & 8.5 & 15 & $19+$ & & $\mathrm{A}$ & \\
\hline & $230-1$ & $11-\mathrm{H}$ & surface & $41+$ & 39 & 10 & 18 & 23 & 24 & $\mathrm{~A} / \mathrm{B}$ & \\
\hline & $269-1$ & $37-\mathrm{S}$ & 1 & $28+$ & $\mathrm{n} / \mathrm{a}$ & 6 & 11 & 16 & 17 & $\mathrm{~B}$ & base \\
\hline & $288-16$ & $* *$ & & $58+$ & 39 & 6 & 15 & 19 & 18 & $\mathrm{~B} ?$ & tip and barb missing \\
\hline \multicolumn{12}{|c|}{ Martindale } \\
\hline & 21-1 & $22-\mathrm{E}$ & 3 & $32+$ & $36+$ & 6 & 16 & 14 & 26 & $\mathrm{~B}$ & proximal \\
\hline & $24-1$ & $20-\mathrm{A}$ & 2 & $54+$ & 36 & 7 & 19 & 14 & 24 & $\mathrm{C}$ & $\begin{array}{l}\text { heavy patina, parallel } \\
\text { oblique }\end{array}$ \\
\hline & $58-1$ & $29-\mathrm{V}$ & 1 & 44 & $28+$ & 7 & 13 & 17 & 23.5 & $\mathrm{n} / \mathrm{a}$ & barbs missing, biconvex \\
\hline & $130-1$ & 27-M & 3 & 41 & 23 & 7 & 15 & 17 & 25 & $\mathrm{D}$ & blade reworked \\
\hline & $178-2$ & $22-\mathrm{G}$ & 3 & 46 & 26.5 & 7 & 13.5 & 18 & 24 & $\mathrm{X} / \mathrm{D}$ & classic Martindale \\
\hline & $189-2$ & $19-\mathrm{E}$ & 1 & $41.5+$ & $24+$ & 6 & 12 & 18 & 19 & $\mathrm{~A}$ & \\
\hline
\end{tabular}

* Key to types of breakage patterns:

$\mathrm{X}=$ complete point

$\mathrm{A}=$ direct impact break at the tip, barbs, or base (often appears as a "burin-like" break, though more commonly as a flute-like flake extending from the tip down one face of the point)

$\mathrm{B}=$ snap or bending fracture probably caused by impact on used points or manufacturing mistakes on preforms

$\mathrm{C}=$ burned (usually marked by crazing fractures and pot lid fractures on the artifact)

$\mathrm{D}=$ reworked tip or blade

Points with more than one break were labeled accordingly; e.g. if evidence for both direct impact and snap break was observed, the breakage pattern was coded as A/B.

** Lot No. 288 contains artifacts for which the unit number was eroded and could not be read.

*** Lot No. 310 contains artifacts from other work at Spring Lake. See end note, Chapter 3. 
Appendix A. Projectile Points, continued

\begin{tabular}{|c|c|c|c|c|c|c|c|c|c|c|c|}
\hline Type & $\begin{array}{l}\text { Spec. } \\
\text { No. }\end{array}$ & Unit & Level & $\begin{array}{l}\text { Length } \\
\text { (mm) }\end{array}$ & $\begin{array}{l}\text { Width } \\
\text { (mm) }\end{array}$ & $\begin{array}{l}\text { Thick- } \\
\text { ness } \\
\text { (mm) }\end{array}$ & $\begin{array}{l}\text { Stem } \\
\text { Length } \\
\text { (mm) }\end{array}$ & $\begin{array}{l}\text { Stem } \\
\text { Width } \\
(\mathrm{mm})\end{array}$ & $\begin{array}{c}\text { Base } \\
\text { Width } \\
(\mathrm{mm})\end{array}$ & $\begin{array}{l}\text { Break } \\
\text { Type* }\end{array}$ & Notes, Comments \\
\hline & $288-14$ & $* *$ & & 40 & 25 & 7 & 12 & 13 & 22 & $\mathrm{D}$ & base convex \\
\hline & $300-1$ & & & 40 & 26 & 7 & 10 & 14 & 20 & $\mathrm{n} / \mathrm{a}$ & complete \\
\hline \multicolumn{12}{|c|}{ Merrell } \\
\hline & $176-1$ & $22-\mathrm{B}$ & 2 & 52 & 36 & 6 & 14 & 17 & 0 & $\mathrm{D}$ & base ear missing \\
\hline \multicolumn{12}{|c|}{ Montell } \\
\hline & $11-1$ & $37-\mathrm{V}$ & 2 & 57 & 26 & 6 & 13 & 18 & 21 & $\mathrm{D}$ & complete, reworked blade \\
\hline & $19-1$ & $27-\mathrm{H}$ & 5 & $31+$ & $40+$ & 6.5 & 19 & 15 & 22 & $\mathrm{~B}$ & \\
\hline & $20-1$ & 26-C & 5 & $50+$ & $28.5+$ & 5.5 & 20 & 14 & 22.5 & $\mathrm{~A}, \mathrm{~B}$ & transluscent chert \\
\hline & $68-1$ & $31-\mathrm{E}$ & & $29.5+$ & $23.5^{+}$ & 5.5 & 14 & 17 & 21 & $\mathrm{~B}$ & \\
\hline & $77-1$ & $31-\mathrm{F}$ & & $52+$ & 27 & 6 & 14 & 20 & 21 & $\mathrm{~A} / \mathrm{B}$ & top missing; base damaged \\
\hline & $83-1$ & $31-\mathrm{H}$ & 5 & 59 & 29 & 6.5 & 14 & 18 & 20.5 & $\mathrm{~A}$ & $\begin{array}{l}\text { beat up edges, stream dam- } \\
\text { age? }\end{array}$ \\
\hline & $139-1$ & $27-\mathrm{F}$ & 2 & $26+$ & $32+$ & $6.5+$ & - & - & - & $\mathrm{A}$ & $\begin{array}{l}\text { prox, likely of a Montell } \\
\text { point; heavily damaged }\end{array}$ \\
\hline & $160-2$ & $33-\mathrm{Q}$ & 1 & $38+$ & 17 & 6 & 14 & 19 & 22 & $\mathrm{~A} / \mathrm{B}$ & Montell \\
\hline & $172-1$ & $22-\mathrm{E}$ & 1 & $13+$ & $19+$ & $6+$ & 10 & 13 & 17 & $\mathrm{C}$ & small \\
\hline & $191-2$ & 19-A & 1 & $28+$ & 37 & 5 & 11 & 22 & $24+$ & $\mathrm{B}$ & base \\
\hline & $198-1$ & $24-\mathrm{G}$ & 2 & $44+$ & $33+$ & 5 & 11 & 22 & - & $\mathrm{A}$ & base \\
\hline & $267-2$ & $36-\mathrm{U}$ & 2 & 55 & 48 & 12 & 10 & 23 & 23 & & flaw, novice? \\
\hline & $288-25$ & $* *$ & & $63+$ & $33+$ & 6 & 16 & 22 & 25 & $\mathrm{~A}$ & tip, barbs missing \\
\hline
\end{tabular}

* Key to types of breakage patterns:

$\mathrm{X}=$ complete point

$\mathrm{A}=$ direct impact break at the tip, barbs, or base (often appears as a "burin-like" break, though more commonly as a flute-like flake extending from the tip down one face of the point)

$\mathrm{B}=$ snap or bending fracture probably caused by impact on used points or manufacturing mistakes on preforms

$\mathrm{C}=$ burned (usually marked by crazing fractures and pot lid fractures on the artifact)

$\mathrm{D}=$ reworked tip or blade

Points with more than one break were labeled accordingly; e.g. if evidence for both direct impact and snap break was observed, the breakage pattern was coded as A/B.

** Lot No. 288 contains artifacts for which the unit number was eroded and could not be read.

*** Lot No. 310 contains artifacts from other work at Spring Lake. See end note, Chapter 3. 
Appendix A. Projectile Points, continued

\begin{tabular}{|c|c|c|c|c|c|c|c|c|c|c|c|}
\hline Type & $\begin{array}{c}\text { Spec. } \\
\text { No. }\end{array}$ & Unit & Level & $\begin{array}{l}\text { Length } \\
(\mathrm{mm})\end{array}$ & $\begin{array}{l}\text { Width } \\
\text { (mm) }\end{array}$ & $\begin{array}{c}\text { Thick- } \\
\text { ness } \\
(\mathrm{mm})\end{array}$ & $\begin{array}{c}\text { Stem } \\
\text { Length } \\
(\mathrm{mm})\end{array}$ & $\begin{array}{c}\text { Stem } \\
\text { Width } \\
(\mathrm{mm})\end{array}$ & $\begin{array}{c}\text { Base } \\
\text { Width } \\
(\mathrm{mm})\end{array}$ & $\begin{array}{l}\text { Break } \\
\text { Type* }\end{array}$ & Notes, Comments \\
\hline \multicolumn{12}{|c|}{ Nolan } \\
\hline & $3-1$ & $13-\mathrm{F}$ & 11 & 84 & 30 & 8 & 24 & 18 & 16.5 & $\mathrm{~A} / \mathrm{D}$ & impact reworked \\
\hline & $39-1$ & $28-\mathrm{C}$ & 5 & $78+$ & 28 & 11 & 21 & 19 & 18 & $\mathrm{~A}$ & \\
\hline & $44-1$ & $28-\mathrm{F}$ & 1 & $44+$ & $27+$ & 9 & 20 & 16 & 19 & $\mathrm{~A} / \mathrm{B}$ & stem unificially beveled \\
\hline & $48-2$ & $29-\mathrm{F}$ & 5 & 41 & 21 & 8 & 15 & 15 & 15 & $\mathrm{X} / \mathrm{D}$ & heavily reworked \\
\hline & $50-2$ & $29-G$ & 6 & $20+$ & $20+$ & $7+$ & 17 & 17 & 19 & $\mathrm{C}$ & stem \\
\hline & $71-1$ & $31-\mathrm{S}$ & & $63.5^{+}$ & 29 & 8 & 24 & 16 & 21 & $\mathrm{~B}$ & proximal \\
\hline & $93-1$ & $30-\mathrm{F}$ & 1 & 68.5 & 25 & 8 & 19 & 18 & 19 & $\mathrm{X}$ & \\
\hline & $98-1$ & $30-\mathrm{G}$ & 1 & 60 & 21 & 9 & 16 & 17 & 16 & $\mathrm{~A}$ & much reworked \\
\hline & $103-1$ & $30-\mathrm{W}$ & 2 & $52.5+$ & 24 & 8 & 22 & 18 & 19.5 & $\mathrm{~A}$ & blade beveled to left \\
\hline & $133-3$ & $27-\mathrm{I}$ & 1 & $51+$ & 29 & 8 & 16 & 19 & 19 & $\mathrm{~A}$ & \\
\hline & $137-1$ & $27-\mathrm{K}$ & 3 & 65 & 22 & 8.5 & 14 & 16 & 16 & $\mathrm{X}$ & alt bev right on stem \\
\hline & $166-1$ & $14-\mathrm{H}$ & surface & $60+$ & 26 & 9 & 18 & 20 & 20 & A & tip missing \\
\hline & $166-2$ & $13-\mathrm{H}$ & surface & $59+$ & 25 & 6.5 & 22 & 17 & 16 & A & $\begin{array}{l}\text { Nolan, casually made on a } \\
\text { flake }\end{array}$ \\
\hline & $171-2$ & $22-\mathrm{C}$ & 1 & $21+$ & 22 & $7+$ & 22 & 19 & 21 & $\mathrm{~B}$ & stem \\
\hline & $183-2$ & $20-\mathrm{I}$ & surface & 63 & 24 & 9.5 & 21 & 19.5 & 21 & $\mathrm{D}$ & asymmetrical, drill? \\
\hline & $215-1$ & $28-G$ & 2 & $31+$ & 24 & 6 & 14 & 15 & 15 & $\mathrm{~B}$ & \\
\hline & $257-1$ & $14-\mathrm{H}$ & surface & $34+$ & $32+$ & 7 & 12 & 18 & 18 & $\mathrm{~B}$ & base \\
\hline & $288-56$ & $* *$ & & $66+$ & 30 & 18 & 10 & 18 & 18 & $\mathrm{~B}$ & tip missing \\
\hline
\end{tabular}

* Key to types of breakage patterns:

$\mathrm{X}=$ complete point

$\mathrm{A}=$ direct impact break at the tip, barbs, or base (often appears as a "burin-like" break, though more commonly as a flute-like flake extending from the tip down one face of the point)

$\mathrm{B}=$ snap or bending fracture probably caused by impact on used points or manufacturing mistakes on preforms

$\mathrm{C}=$ burned (usually marked by crazing fractures and pot lid fractures on the artifact)

$\mathrm{D}=$ reworked tip or blade

Points with more than one break were labeled accordingly; e.g. if evidence for both direct impact and snap break was observed, the breakage pattern was coded as A/B.

** Lot No. 288 contains artifacts for which the unit number was eroded and could not be read.

*** Lot No. 310 contains artifacts from other work at Spring Lake. See end note, Chapter 3. 
Appendix A. Projectile Points, continued

\begin{tabular}{|c|c|c|c|c|c|c|c|c|c|c|c|}
\hline Type & $\begin{array}{c}\text { Spec. } \\
\text { No. }\end{array}$ & Unit & Level & $\begin{array}{c}\text { Length } \\
\text { (mm) }\end{array}$ & $\begin{array}{c}\text { Width } \\
(\mathrm{mm})\end{array}$ & $\begin{array}{c}\text { Thick- } \\
\text { ness } \\
(\mathrm{mm})\end{array}$ & $\begin{array}{c}\text { Stem } \\
\text { Length } \\
(\mathrm{mm})\end{array}$ & $\begin{array}{c}\text { Stem } \\
\text { Width } \\
(\mathrm{mm}) \\
\end{array}$ & $\begin{array}{c}\text { Base } \\
\text { Width } \\
(\mathrm{mm})\end{array}$ & $\begin{array}{l}\text { Break } \\
\text { Type* }\end{array}$ & Notes, Comments \\
\hline \multicolumn{12}{|c|}{ Pedernales } \\
\hline & 8-1 & $27-\mathrm{E}$ & 4 & 63 & 34 & 7 & 18 & 24 & 21 & $\mathrm{D} / \mathrm{X}$ & reworked blade \\
\hline & $10-1$ & $13-\mathrm{F}$ & 2 & 54.5 & 31 & 6.5 & 18 & 22 & 21 & $\mathrm{X}$ & complete \\
\hline & $39-4$ & $28-\mathrm{C}$ & 5 & 68.5 & 34 & 7 & 23 & 18 & 20 & $\mathrm{~A}$ & tip, barb missing \\
\hline & $50-5$ & $29-\mathrm{G}$ & 6 & $58.5+$ & 34 & 7 & 14 & 19 & 16 & $\mathrm{~A}$ & tip missing \\
\hline & $64-2$ & $26-\mathrm{F}$ & 5 & $17.5^{+}$ & $24+$ & $7+$ & & - & - & B & stem only \\
\hline & $70-1$ & $31-\mathrm{E}$ & & $28+$ & $24+$ & $6+$ & $17+$ & 21 & - & $\mathrm{C}$ & stem only \\
\hline & $82-2$ & $31-\mathrm{H}$ & 3 & $16+$ & $22+$ & 5 & & 21 & 22 & $\mathrm{~B}$ & base only \\
\hline & $132-2$ & $27-\mathrm{C}$ & 5 & $16+$ & $24+$ & $6+$ & & & 20 & $\mathrm{C}$ & stem frag of Pedernales \\
\hline & $151-1$ & $23-\mathrm{G}$ & 1 & 73 & 29 & 7 & 20 & 20 & 16 & $\mathrm{~A}$ & partial impact shatter at tip \\
\hline & $182-1$ & $20-\mathrm{G}$ & 1 & 64 & $38+$ & 8 & 19 & 20 & 19 & $\mathrm{~A} / \mathrm{D}$ & asymmetrical \\
\hline & $187-1$ & $19-\mathrm{H}$ & surface & $20+$ & 22.5 & $5+$ & 16 & 21 & 19 & $\mathrm{~B}$ & stem frag \\
\hline & $194-1$ & $18-\mathrm{I}$ & 1 & 18 & 16 & 6 & - & - & - & $\mathrm{A} / \mathrm{B}$ & \\
\hline & 204-2 & $34-\mathrm{X}$ & 3 & $62+$ & $31+$ & 9 & 18 & 21 & 22 & A & proximal \\
\hline & $211-1$ & $28-\mathrm{H}$ & 2 & 63 & 32 & 9 & 11 & 17 & 12 & $\mathrm{X}$ & novice \\
\hline & $222-1$ & 24-A & 1 & $50+$ & 29 & 9 & 12 & 14 & 14 & $\mathrm{~A} / \mathrm{B}$ & \\
\hline & $227-1$ & $32-\mathrm{V}$ & 1 & $60+$ & 39 & 7 & 14 & 20 & 20 & $\mathrm{~A}$ & \\
\hline & $249-1$ & $15-\mathrm{C}$ & 1 & 61 & 31 & 9 & 19 & 20 & 18 & B & tip missing \\
\hline & 258-1 & $14-\mathrm{L}$ & surface & $16+$ & 17 & 6 & 16 & - & 16 & $\mathrm{~B}$ & \\
\hline
\end{tabular}

* Key to types of breakage patterns:

$\mathrm{X}=$ complete point

A = direct impact break at the tip, barbs, or base (often appears as a "burin-like" break, though more commonly as a flute-like flake extending from the tip down one face of the point)

$\mathrm{B}=$ snap or bending fracture probably caused by impact on used points or manufacturing mistakes on preforms

$\mathrm{C}=$ burned (usually marked by crazing fractures and pot lid fractures on the artifact)

$\mathrm{D}=$ reworked tip or blade

Points with more than one break were labeled accordingly; e.g. if evidence for both direct impact and snap break was observed, the breakage pattern was coded as A/B.

** Lot No. 288 contains artifacts for which the unit number was eroded and could not be read. 
Appendix A. Projectile Points, continued

\begin{tabular}{|c|c|c|c|c|c|c|c|c|c|c|c|}
\hline Туре & $\begin{array}{l}\text { Spec. } \\
\text { No. }\end{array}$ & Unit & Level & $\begin{array}{l}\text { Length } \\
\text { (mm) }\end{array}$ & $\begin{array}{l}\text { Width } \\
\text { (mm) }\end{array}$ & $\begin{array}{c}\text { Thick- } \\
\text { ness } \\
(\mathrm{mm})\end{array}$ & $\begin{array}{c}\text { Stem } \\
\text { Length } \\
(\mathbf{m m})\end{array}$ & $\begin{array}{c}\text { Stem } \\
\text { Width } \\
(\mathrm{mm})\end{array}$ & $\begin{array}{c}\text { Base } \\
\text { Width } \\
\text { (mm) }\end{array}$ & $\begin{array}{l}\text { Break } \\
\text { Type* }\end{array}$ & Notes, Comments \\
\hline & $270-1$ & $37-\mathrm{T}$ & 2 & $53+$ & 40 & 7 & $19+$ & 25 & 25 & $\mathrm{~A} / \mathrm{B}$ & proximal \\
\hline & $278-1$ & $3-\mathrm{T}$ & 1 & $77+$ & 32 & 8 & 22 & 20 & 19 & $\mathrm{~B}$ & tip missing \\
\hline & $283-1$ & $39-\mathrm{W}$ & 2 & $38+$ & 32 & 7 & 14 & 13 & 12 & $\mathrm{~B}$ & proximal \\
\hline & $288-6$ & $* *$ & & $63+$ & $40+$ & 6 & 16 & 24 & 21 & A & tip missing \\
\hline & $288-26$ & $* *$ & & 53 & 39 & 5 & 11 & 19 & $21+$ & $\mathrm{D}$ & \\
\hline \multicolumn{12}{|c|}{ San Patrice } \\
\hline & $309-5$ & & & 34 & 22 & 5 & 13 & 22 & 26 & $\mathrm{X}$ & fluted on one face \\
\hline \multicolumn{12}{|c|}{ St. Mary's Hall } \\
\hline & $11-3$ & $37-\mathrm{V}$ & 2 & $40+$ & $29+$ & 5 & & & & & $\begin{array}{l}\text { medial, oblique parallel, } \\
\text { burin }\end{array}$ \\
\hline & $25-1$ & $28-\mathrm{E}$ & 5 & $18.5+$ & 21.5 & 6 & $\mathrm{n} / \mathrm{a}$ & $\mathrm{n} / \mathrm{a}$ & 19 & B & ground edges \\
\hline & $26-1$ & $20-\mathrm{F}$ & 1 & 23 & 23 & 5 & & 22 & 22 & B & base \\
\hline & $28-1$ & $32-\mathrm{S}$ & 2 & $20+$ & $19+$ & $5+$ & - & 0 & 19 & $\mathrm{C}$ & $\begin{array}{l}\text { base Paleoindian, light lat- } \\
\text { eral dulling }\end{array}$ \\
\hline & $29-1$ & $29-\mathrm{G}$ & 2 & $14+$ & 20 & $4.5+$ & & & 19.5 & B & $\begin{array}{l}\text { base frag prob St. Mary's } \\
\text { Hall; vertical thinning } \\
\text { flakes; light edge dulling }\end{array}$ \\
\hline & $34-2$ & $31-\mathrm{G}$ & 5 & $49+$ & 25 & 6 & 23 & 25 & 19.5 & B & $\begin{array}{l}\text { final stage preform; basal } \\
\text { edge has platform for thin- } \\
\text { ning and parallel oblique } \\
\text { flakes }\end{array}$ \\
\hline
\end{tabular}

* Key to types of breakage patterns:

$\mathrm{X}=$ complete point

$\mathrm{A}=$ direct impact break at the tip, barbs, or base (often appears as a "burin-like" break, though more commonly as a flute-like flake extending from the tip down one face of the point)

$\mathrm{B}=$ snap or bending fracture probably caused by impact on used points or manufacturing mistakes on preforms

$\mathrm{C}=$ burned (usually marked by crazing fractures and pot lid fractures on the artifact)

$\mathrm{D}=$ reworked tip or blade

Points with more than one break were labeled accordingly; e.g. if evidence for both direct impact and snap break was observed, the breakage pattern was coded as A/B.

** Lot No. 288 contains artifacts for which the unit number was eroded and could not be read.

$* * *$ Lot No. 310 contains artifacts from other work at Spring Lake. See end note, Chapter 3. 
Appendix A. Projectile Points, continued

\begin{tabular}{|c|c|c|c|c|c|c|c|c|c|c|c|}
\hline Type & $\begin{array}{l}\text { Spec. } \\
\text { No. }\end{array}$ & Unit & Level & $\begin{array}{l}\text { Length } \\
\text { (mm) }\end{array}$ & $\begin{array}{l}\text { Width } \\
(\mathrm{mm})\end{array}$ & $\begin{array}{l}\text { Thick- } \\
\text { ness } \\
(\mathrm{mm})\end{array}$ & $\begin{array}{l}\text { Stem } \\
\text { Length } \\
(\mathrm{mm})\end{array}$ & $\begin{array}{l}\text { Stem } \\
\text { Width } \\
\text { (mm) }\end{array}$ & $\begin{array}{l}\text { Base } \\
\text { Width } \\
\text { (mm) }\end{array}$ & $\begin{array}{l}\text { Break } \\
\text { Type* }\end{array}$ & Notes, Comments \\
\hline & $60-3$ & $26-\mathrm{B}$ & 5 & $39+$ & 23 & 6.5 & - & & $20+$ & $\mathrm{A} / \mathrm{B} / \mathrm{C}$ & $\begin{array}{l}\text { parallel oblique, preform for } \\
\text { St. Mary's Hall point }\end{array}$ \\
\hline & $63-3$ & $26-\mathrm{F}$ & 4 & 30.5 & 17 & 6.5 & 13 & 26 & $14+$ & $\mathrm{A} / \mathrm{C}$ & $\begin{array}{l}\text { prox; St. Mary's Hall paral- } \\
\text { lel oblique, edges dulled; } \\
\text { burned; impact fractures }\end{array}$ \\
\hline & $86-2$ & $30-\mathrm{C}$ & 2 & $50+$ & $19+$ & 8.5 & - & & - & $\mathrm{A} / \mathrm{C}$ & parallel oblique flaking \\
\hline & $131-4$ & $27-\mathrm{C}$ & 4 & $40+$ & 18 & 6 & & & & $\mathrm{~A}$ & distal St. Mary's Hall \\
\hline & $201-2$ & $21-\mathrm{C}$ & 2 & $50+$ & 28 & 6 & & & & $\mathrm{~B} / \mathrm{D}$ & $\begin{array}{l}\text { oblique parallel, part grind- } \\
\text { ing }\end{array}$ \\
\hline & 201-4 & $21-\mathrm{C}$ & 2 & $20+$ & 19 & 5 & - & - & - & $\mathrm{C}$ & medial with oblique-parallel \\
\hline & $226-1$ & $32-\mathrm{U}$ & 2 & $54+$ & 19 & 6 & 21 & 16 & 15 & $\mathrm{~A} / \mathrm{B}$ & \\
\hline & $239-1$ & $12-\mathrm{J}$ & surface & $22+$ & 17 & 5 & - & - & - & & medial with oblique-parallel \\
\hline & $239-2$ & 12-J & surface & $35+$ & 27 & 8 & - & - & - & & medial with parallel flaking \\
\hline & $253-2$ & $15-\mathrm{N}$ & surface & 62 & 18 & 6 & 21 & 20 & 20 & $\mathrm{D}$ & edge beveled right \\
\hline & $256-1$ & $14-\mathrm{F}$ & surface & $14+$ & $17 ?$ & 4 & $\mathrm{n} / \mathrm{a}$ & 18 & 17 & B & base \\
\hline & $265-1$ & $36-\mathrm{T}$ & 2 & 57 & 19 & 5 & 18 & 19 & 20 & $\mathrm{D}$ & moderate basal grinding \\
\hline & $271-1$ & $37-\mathrm{V}$ & 1 & $22+$ & 19 & 7 & $\mathrm{n} / \mathrm{a}$ & $\mathrm{n} / \mathrm{a}$ & $\mathrm{n} / \mathrm{a}$ & $\mathrm{C}$ & beveled right, medial frag \\
\hline
\end{tabular}

* Key to types of breakage patterns:

$\mathrm{X}=$ complete point

A = direct impact break at the tip, barbs, or base (often appears as a "burin-like" break, though more commonly as a flute-like flake extending from the tip down one face of

the point)

$\mathrm{B}=$ snap or bending fracture probably caused by impact on used points or manufacturing mistakes on preforms

$\mathrm{C}=$ burned (usually marked by crazing fractures and pot lid fractures on the artifact)

$\mathrm{D}=$ reworked tip or blade

Points with more than one break were labeled accordingly; e.g. if evidence for both direct impact and snap break was observed, the breakage pattern was coded as A/B.

** Lot No. 288 contains artifacts for which the unit number was eroded and could not be read.

*** Lot No. 310 contains artifacts from other work at Spring Lake. See end note, Chapter 3. 
Appendix A. Projectile Points, continued

\begin{tabular}{|c|c|c|c|c|c|c|c|c|c|c|c|}
\hline Type & $\begin{array}{l}\text { Spec. } \\
\text { No. }\end{array}$ & Unit & Level & $\begin{array}{c}\text { Length } \\
(\mathrm{mm})\end{array}$ & $\begin{array}{c}\text { Width } \\
(\mathrm{mm})\end{array}$ & $\begin{array}{c}\text { Thick- } \\
\text { ness } \\
(\mathrm{mm})\end{array}$ & $\begin{array}{c}\text { Stem } \\
\text { Length } \\
(\mathbf{m m})\end{array}$ & $\begin{array}{c}\text { Stem } \\
\text { Width } \\
(\mathrm{mm}) \\
\end{array}$ & $\begin{array}{c}\text { Base } \\
\text { Width } \\
(\mathrm{mm})\end{array}$ & $\begin{array}{l}\text { Break } \\
\text { Type* }\end{array}$ & Notes, Comments \\
\hline & $288-29$ & $* *$ & & $34+$ & 24 & 7 & $\mathrm{n} / \mathrm{a}$ & $\mathrm{n} / \mathrm{a}$ & $\mathrm{n} / \mathrm{a}$ & $\mathrm{B} / ?$ & $\begin{array}{l}\text { oblique parallel, part grind- } \\
\text { ing }\end{array}$ \\
\hline & $288-58$ & $* *$ & & $41+$ & 27 & 8 & & & & $\mathrm{~B} / \mathrm{B}$ & medial frag \\
\hline & $288-59$ & $* *$ & & $64+$ & 23 & 9 & 27 & 23 & 20 & A & mult flute on one side \\
\hline & $289-1$ & $27-\mathrm{G}$ & 5 & $62+$ & 20 & 8 & $\mathrm{n} / \mathrm{a}$ & $\mathrm{n} / \mathrm{a}$ & $\mathrm{n} / \mathrm{a}$ & $\mathrm{B} / \mathrm{B}$ & medial, oblique parallel \\
\hline & $293-1$ & $30-\mathrm{I}$ & 1 & $88+$ & 22 & 6 & 20 & 20 & 18 & B & tip missing; oblique-parallal \\
\hline & $295-1$ & $20-\mathrm{B}$ & 3 & $21+$ & $\mathrm{n} / \mathrm{a}$ & 6 & $21+$ & 19 & 18 & $\mathrm{~B}$ & base \\
\hline & $296-1$ & $13-\mathrm{K}$ & 1 & 85 & 19 & 7 & 23 & 18 & 19 & $\mathrm{X}$ & basal grinding, no oblique \\
\hline & $297-1$ & $39-5$ & 1 & $20+$ & 17 & 6 & 18 & 18 & 17 & B & base, basal grinding \\
\hline & $298-1$ & $21-\mathrm{F}$ & 4 & 45 & 19 & 6 & 20 & 22 & 20 & $\mathrm{~A} / \mathrm{D}$ & beveled right \\
\hline & $301-1$ & $22-\mathrm{D}$ & 1 & $12+$ & $\mathrm{n} / \mathrm{a}$ & 6 & $\mathrm{n} / \mathrm{a}$ & 17 & $\mathrm{n} / \mathrm{a}$ & $\mathrm{B}$ & ground edges \\
\hline & $302-1$ & $33-\mathrm{O}$ & 1 & $27+$ & 24 & 6 & $\mathrm{n} / \mathrm{a}$ & $\mathrm{n} / \mathrm{a}$ & $\mathrm{n} / \mathrm{a}$ & $\mathrm{A}$ & medial, oblique parallel \\
\hline & $308-1$ & $17-\mathrm{O}$ & 1 & $31+$ & 22 & 5 & $\mathrm{n} / \mathrm{a}$ & $\mathrm{n} / \mathrm{a}$ & $\mathrm{n} / \mathrm{a}$ & $\mathrm{B}$ & medial, oblique parallel \\
\hline & $310-3$ & $* * *$ & $\mathrm{n} / \mathrm{a}$ & $74+$ & 21 & 7 & 16 & 21 & 21 & $\mathrm{~B}$ & tip missing \\
\hline \multicolumn{12}{|c|}{ Travis } \\
\hline & $50-6$ & $29-\mathrm{G}$ & 6 & 70 & 24 & 9 & 16 & 20 & 22 & $\mathrm{C}$ & burned tip \\
\hline & $92-1$ & $30-\mathrm{I}$ & 4 & 43.5 & 21.5 & 7 & 15 & 17 & 17 & $\mathrm{D}$ & reworked blade \\
\hline & $133-4$ & $29-\mathrm{I}$ & 4 & $31+$ & 29 & 8 & 12 & 16 & $14+$ & $\mathrm{C}$ & burned \\
\hline & $158-2$ & $33-\mathrm{R}$ & 1 & $57+$ & 32 & 9 & 15 & 17 & 14 & $\mathrm{~B}$ & $\begin{array}{l}\text { narrow stem Nolan-like not } \\
\text { beveled }\end{array}$ \\
\hline
\end{tabular}

* Key to types of breakage patterns:

$\mathrm{X}=$ complete point

$\mathrm{A}=$ direct impact break at the tip, barbs, or base (often appears as a "burin-like" break, though more commonly as a flute-like flake extending from the tip down one face of the point)

$\mathrm{B}=$ snap or bending fracture probably caused by impact on used points or manufacturing mistakes on preforms

$\mathrm{C}=$ burned (usually marked by crazing fractures and pot lid fractures on the artifact)

$\mathrm{D}=$ reworked tip or blade

Points with more than one break were labeled accordingly; e.g. if evidence for both direct impact and snap break was observed, the breakage pattern was coded as A/B.

** Lot No. 288 contains artifacts for which the unit number was eroded and could not be read.

*** Lot No. 310 contains artifacts from other work at Spring Lake. See end note, Chapter 3. 
Appendix A. Projectile Points, continued

\begin{tabular}{|c|c|c|c|c|c|c|c|c|c|c|c|}
\hline Type & $\begin{array}{c}\text { Spec. } \\
\text { No. }\end{array}$ & Unit & Level & $\begin{array}{c}\text { Length } \\
\text { (mm) }\end{array}$ & $\begin{array}{l}\text { Width } \\
(\mathrm{mm})\end{array}$ & $\begin{array}{c}\text { Thick- } \\
\text { ness } \\
(\mathrm{mm})\end{array}$ & $\begin{array}{c}\text { Stem } \\
\text { Length } \\
(\mathrm{mm})\end{array}$ & $\begin{array}{l}\text { Stem } \\
\text { Width } \\
(\mathrm{mm})\end{array}$ & $\begin{array}{c}\text { Base } \\
\text { Width } \\
(\mathrm{mm})\end{array}$ & $\begin{array}{l}\text { Break } \\
\text { Type* }\end{array}$ & Notes, Comments \\
\hline & $190-1$ & $19-\mathrm{B}$ & 3 & $21+$ & - & 7 & 9 & 17 & 17 & $\mathrm{~A} / \mathrm{B}$ & base \\
\hline & $194-2$ & 18-i) & surface & 56 & 19 & 8 & 15 & 14 & 15 & & complete \\
\hline & $202-1$ & $34-\mathrm{U}$ & 3 & $48+$ & 26 & 6 & 13 & 16 & 16 & $\mathrm{~B}$ & \\
\hline & $225-1$ & $32-\mathrm{U}$ & 1 & $62+$ & 23 & 7 & 13 & 14 & 13 & $\mathrm{D}$ & asymmetrical \\
\hline & $231-2$ & 11-I & surface & $55+$ & 31 & 9 & 15 & 20 & 20 & $\mathrm{~B}$ & base \\
\hline & $242-1$ & $12-\mathrm{N}$ & surface & 50 & N/A & 8 & 15 & 17 & 17 & $\mathrm{D}$ & \\
\hline & $288-13$ & $* *$ & & $27+$ & 26 & 6 & 13 & 17 & 17 & $\mathrm{~B}$ & base, tech does not fit \\
\hline & $288-15$ & $* *$ & & $42+$ & 24 & 7 & 13 & 19 & 10 & $\mathrm{~B}$ & \\
\hline & $288-18$ & $* *$ & & $60+$ & 25 & 8 & 17 & 18 & 18 & $\mathrm{~A}$ & \\
\hline & $288-36$ & $* *$ & & $45+$ & 32 & 9 & 16 & 17 & 17 & $\mathrm{~B} / \mathrm{D}$ & \\
\hline & $288-45$ & $* *$ & & 56 & 23 & 8 & 15 & 15 & 17 & $\mathrm{D}$ & complete \\
\hline & $304-1$ & $19-\mathrm{F}$ & $?$ & 66 & 20 & 8 & 19 & 16 & 15 & & very narrow \\
\hline \multicolumn{12}{|c|}{ Uvalde/Gower } \\
\hline & $20-2$ & 26-C & 5 & $36+$ & $26.5+$ & 6 & 11 & 14 & 13.5 & $\mathrm{~A} / \mathrm{B}$ & impact led to reworking \\
\hline & $63-2$ & $26-\mathrm{F}$ & 4 & $34+$ & $30+$ & 7 & 12 & 8 & 15.5 & $\mathrm{~B}$ & prox \\
\hline & $142-1$ & $27-\mathrm{B}$ & 1 & $28+$ & $23+$ & 6 & 12 & 13 & $14+$ & $\mathrm{B}$ & Gower thick, biconvex; stem \\
\hline & $167-1$ & 13-I & 1 & $33.5+$ & 31 & 7 & 16 & 15 & 17 & $\mathrm{~B} / \mathrm{C}$ & \\
\hline & $175-1$ & $22-\mathrm{C}$ & 1 & 58 & 23 & 7 & 12 & 17.5 & $18+$ & $\mathrm{A} / \mathrm{D}$ & \\
\hline & $189-1$ & $19-\mathrm{E}$ & surf/1 & $45+$ & $23+$ & 8 & 21 & 15 & & $\mathrm{~A}, \mathrm{D}$ & reworked blade twist to right \\
\hline
\end{tabular}

* Key to types of breakage patterns:

$\mathrm{X}=$ complete point

A = direct impact break at the tip, barbs, or base (often appears as a "burin-like" break, though more commonly as a flute-like flake extending from the tip down one face of the point)

$\mathrm{B}=$ snap or bending fracture probably caused by impact on used points or manufacturing mistakes on preforms

$\mathrm{C}=$ burned (usually marked by crazing fractures and pot lid fractures on the artifact)

$\mathrm{D}=$ reworked tip or blade

Points with more than one break were labeled accordingly; e.g. if evidence for both direct impact and snap break was observed, the breakage pattern was coded as A/B.

** Lot No. 288 contains artifacts for which the unit number was eroded and could not be read. 
Appendix A. Projectile Points, continued

\begin{tabular}{|c|c|c|c|c|c|c|c|c|c|c|c|}
\hline Type & $\begin{array}{c}\text { Spec. } \\
\text { No. }\end{array}$ & Unit & Level & $\begin{array}{c}\text { Length } \\
(\mathrm{mm})\end{array}$ & $\begin{array}{c}\text { Width } \\
(\mathrm{mm})\end{array}$ & $\begin{array}{c}\text { Thick- } \\
\text { ness } \\
(\mathrm{mm})\end{array}$ & $\begin{array}{c}\text { Stem } \\
\text { Length } \\
(\mathrm{mm})\end{array}$ & $\begin{array}{c}\text { Stem } \\
\text { Width } \\
(\mathrm{mm})\end{array}$ & $\begin{array}{c}\text { Base } \\
\text { Width } \\
(\mathrm{mm})\end{array}$ & $\begin{array}{l}\text { Break } \\
\text { Type* }\end{array}$ & Notes, Comments \\
\hline & $200-1$ & $21-\mathrm{B}$ & 2 & $23+$ & - & $5+$ & 12 & 12 & 14 & $\mathrm{C}$ & base frag \\
\hline & $204-1$ & $34-\mathrm{X}$ & 3 & $43+$ & $24+$ & 8 & - & - & - & $\mathrm{A}$ & base frag \\
\hline & $205-2$ & $34-\mathrm{V}$ & 1 & $31+$ & $25+$ & 7 & 14 & 14 & 16 & $\mathrm{~A} / \mathrm{B}$ & \\
\hline & $252-1$ & $15-\mathrm{K}$ & surface & $33+$ & 30 & 6 & 16 & 13 & 20 & B & base frag \\
\hline & $288-38$ & $* *$ & & $51+$ & 17 & 7 & 11 & 11 & - & $?$ & tip missing \\
\hline \multicolumn{12}{|c|}{ Val Verde-like } \\
\hline & $288-44$ & $* *$ & & $38+$ & 32 & 10 & 18 & 9 & 20 & $\mathrm{~A}$ & VV-like in shape, too thick \\
\hline \multicolumn{12}{|c|}{ Williams } \\
\hline & $65-2$ & $26-\mathrm{D}$ & 3 & $21+$ & 32 & 6 & 12 & 16 & 16 & $\mathrm{~B}$ & base \\
\hline & $104-1$ & $25-\mathrm{G}$ & 4 & $35+$ & 34 & 7 & 15 & 18 & 24 & $\mathrm{~B}$ & proximal portion of a Lange \\
\hline & $251-1$ & $15-\mathrm{I}$ & & $29+$ & 27 & 7 & 12 & 13 & 16 & $\mathrm{~B}$ & base \\
\hline \multicolumn{12}{|c|}{ Wilson } \\
\hline & $50-1$ & $29-\mathrm{G}$ & 6 & 55 & 24 & 8.5 & 19 & 21 & 11 & $\mathrm{D}$ & heavily reworked Wilson \\
\hline & $51-1$ & $27-\mathrm{O}$ & 1 & 61 & 26 & 7.5 & 15 & 22 & 26 & $\mathrm{~B}$ & alt-bev stem, base dulling \\
\hline & $53-1$ & $29-\mathrm{H}$ & 5 & $51+$ & 24 & 7.5 & 12 & 20 & $23+$ & $\mathrm{B}$ & basal corner \\
\hline & $90-1$ & $30-\mathrm{U}$ & 1 & $44+$ & $25+$ & 7.5 & 15 & 12 & 19.5 & A & base \\
\hline & $237-1$ & $12-\mathrm{C}$ & surface & 47 & 25 & 9 & 14 & 16 & 20 & $\mathrm{~A}$ & slight basal grinding \\
\hline & $241-1$ & $12-\mathrm{L}$ & surface & $23+$ & 23 & 9 & 15 & 20 & 26 & $\mathrm{~B} / \mathrm{D}$ & stem base grinding \\
\hline \multicolumn{12}{|c|}{ UNTYPED AND UNCLASSIFIABLE DART POINTS } \\
\hline & $8-2$ & $27-\mathrm{E}$ & 4 & 62 & 32.5 & 6 & 8 & 14 & 11.5 & $\mathrm{x}$ & unfinished? \\
\hline \multicolumn{12}{|c|}{$\begin{array}{l}\text { * Key to types of breakage patterns: } \\
\mathrm{X}=\text { complete point } \\
\mathrm{A}=\text { direct impact break at the tip, barbs, or base (often appears as a "burin-like" break, though more commonly as a flute-like flake extending from the tip down one face of } \\
\text { the point) } \\
\mathrm{B}=\text { snap or bending fracture probably caused by impact on used points or manufacturing mistakes on preforms } \\
\mathrm{C}=\text { burned (usually marked by crazing fractures and pot lid fractures on the artifact) } \\
\mathrm{D}=\text { reworked tip or blade } \\
\text { Points with more than one break were labeled accordingly; e.g. if evidence for both direct impact and snap break was observed, the breakage pattern was coded as A/B. }\end{array}$} \\
\hline
\end{tabular}


Appendix A. Projectile Points, continued

\begin{tabular}{|c|c|c|c|c|c|c|c|c|c|c|c|}
\hline Type & $\begin{array}{l}\text { Spec. } \\
\text { No. }\end{array}$ & Unit & Level & $\begin{array}{l}\text { Length } \\
\text { (mm) }\end{array}$ & $\begin{array}{l}\text { Width } \\
\text { (mm) }\end{array}$ & $\begin{array}{l}\text { Thick- } \\
\text { ness } \\
(\mathrm{mm})\end{array}$ & $\begin{array}{c}\text { Stem } \\
\text { Length } \\
\text { (mm) }\end{array}$ & $\begin{array}{l}\text { Stem } \\
\text { Width } \\
(\mathbf{m m})\end{array}$ & $\begin{array}{c}\text { Base } \\
\text { Width } \\
(\mathrm{mm})\end{array}$ & $\begin{array}{l}\text { Break } \\
\text { Type* }\end{array}$ & Notes, Comments \\
\hline & $23-4$ & 26-D & 5 & $39.5+$ & 32 & 4.5 & 31 & 21 & 25 & $\mathrm{C}$ & $\begin{array}{l}\text { very thin, slightly ground } \\
\text { base }\end{array}$ \\
\hline & $27-2$ & $27-\mathrm{D}$ & 5 & $31+$ & $29+$ & $5^{+}$ & 8 & 11 & - & $\mathrm{C}$ & burned to pieces \\
\hline & $52-1$ & $30-\mathrm{M}$ & 1 & $36+$ & 25 & 7 & & 24 & 25 & A & shattered tip \\
\hline & $111-1$ & $29-\mathrm{E}$ & 1 & $35+$ & $28+$ & 7.5 & 13 & 13 & 13 & B & beveled stem but broad blade \\
\hline & $132-1$ & $27-\mathrm{C}$ & 5 & $35+$ & $25+$ & $5.5+$ & $11+$ & 17 & $19+$ & $\mathrm{C}$ & burned stem \\
\hline & $155-1$ & $17-\mathrm{B}$ & 3 & $38+$ & $18+$ & $6+$ & 16 & 16 & 14 & $\mathrm{C}$ & $\begin{array}{l}\text { proximal end, Evant vari- } \\
\text { ant? }\end{array}$ \\
\hline & $168-2$ & 13-J & surface & $20+$ & 21.5 & 7 & 13 & 17 & & B & stem \\
\hline & $170-2$ & 13-S & surface & $19+$ & $21+$ & 4.5 & 17 & 15 & 16 & B & base, part of one shoulder \\
\hline & $188-1$ & $19-\mathrm{E}$ & 2 & $50+$ & $28+$ & $6+$ & 16 & 16 & 0 & $\mathrm{C}$ & burned \\
\hline & $193-1$ & $18-\mathrm{A}$ & 1 & 61 & 27 & 9 & 14 & 22 & 24 & $\mathrm{X}$ & $\begin{array}{l}\text { complete triangular faint } \\
\text { stem }\end{array}$ \\
\hline & $197-1$ & $21-\mathrm{G}$ & 1 & 42 & 32 & 7 & 10 & 16 & 18 & $\mathrm{X}$ & \\
\hline & $259-1$ & $14-\mathrm{O}$ & surface & 60 & 31 & 8 & 19 & 13 & 25 & $\mathrm{X}$ & $\begin{array}{l}\text { expanding stem, straight } \\
\text { base }\end{array}$ \\
\hline & $274-1$ & $38-\mathrm{T}$ & 3 & 35 & 10 & 7 & 17 & 17 & 9 & $\mathrm{X} / \mathrm{D}$ & base unworked, field made \\
\hline & $278-2$ & $39-\mathrm{T}$ & 1 & 48 & 20 & 5 & 8 & 12 & - & A & $\begin{array}{l}\text { base damaged; possibly En- } \\
\text { sor }\end{array}$ \\
\hline & $283-2$ & $39-W$ & 2 & $35+$ & 27 & 6 & 7 & 13 & 15 & $\mathrm{~A} / \mathrm{B}$ & $\begin{array}{l}\text { expanding stem, straight } \\
\text { base }\end{array}$ \\
\hline
\end{tabular}

* Key to types of breakage patterns:

$\mathrm{X}=$ complete point

A = direct impact break at the tip, barbs, or base (often appears as a "burin-like" break, though more commonly as a flute-like flake extending from the tip down one face of the point)

$\mathrm{B}=$ snap or bending fracture probably caused by impact on used points or manufacturing mistakes on preforms

$\mathrm{C}=$ burned (usually marked by crazing fractures and pot lid fractures on the artifact)

$\mathrm{D}=$ reworked tip or blade

Points with more than one break were labeled accordingly; e.g. if evidence for both direct impact and snap break was observed, the breakage pattern was coded as A/B.

** Lot No. 288 contains artifacts for which the unit number was eroded and could not be read.

*** Lot No. 310 contains artifacts from other work at Spring Lake. See end note, Chapter 3. 
Appendix A. Projectile Points, continued

\begin{tabular}{|c|c|c|c|c|c|c|c|c|c|c|c|}
\hline Type & $\begin{array}{l}\text { Spec. } \\
\text { No. }\end{array}$ & Unit & Level & $\begin{array}{c}\text { Length } \\
(\mathrm{mm})\end{array}$ & $\begin{array}{c}\text { Width } \\
(\mathrm{mm})\end{array}$ & $\begin{array}{c}\text { Thick- } \\
\text { ness } \\
(\mathrm{mm})\end{array}$ & $\begin{array}{c}\text { Stem } \\
\text { Length } \\
\text { (mm) }\end{array}$ & $\begin{array}{l}\text { Stem } \\
\text { Width } \\
(\mathrm{mm})\end{array}$ & $\begin{array}{c}\text { Base } \\
\text { Width } \\
(\mathrm{mm})\end{array}$ & $\begin{array}{l}\text { Break } \\
\text { Type* }\end{array}$ & Notes, Comments \\
\hline & $288-3$ & $* *$ & & 87 & 29 & 10 & 16 & 21 & 14 & Failure & contract stem, straight base \\
\hline & $288-39$ & $* *$ & & $44+$ & $20+$ & 7 & 11 & 15 & 18 & $\mathrm{~A}$ & $\begin{array}{l}\text { expanding stem, concave } \\
\text { base }\end{array}$ \\
\hline & $288-57$ & $* *$ & & $50+$ & 35 & 6 & $13+$ & 18 & - & $\mathrm{A}$ & \\
\hline & $288-8$ & $* *$ & & 72 & 32 & 10 & 16 & 18 & 14 & $\mathrm{X}$ & contract stem, round base \\
\hline \multicolumn{12}{|c|}{ ARROW POINTS } \\
\hline \multicolumn{12}{|c|}{ Edwards } \\
\hline & $43-2$ & $28-\mathrm{B}$ & 2 & 32.5 & 16.5 & 4 & 9 & 5 & $16+$ & B & part barb missing \\
\hline & $288-48$ & $* *$ & & $40+$ & 18 & 4 & 8 & 4 & 9 & & tip missing \\
\hline \multicolumn{12}{|c|}{ Perdiz } \\
\hline & $310-5$ & $* * *$ & $\mathrm{n} / \mathrm{a}$ & 28 & 15 & 3 & 8.5 & 6 & 6 & $\mathrm{X}$ & complete \\
\hline \multicolumn{12}{|c|}{ Scallorn } \\
\hline & $151-2$ & $23-\mathrm{G}$ & 1 & 26.5 & $15+$ & 3 & 10 & 9 & 17 & $\mathrm{X}$ & both barbs missing \\
\hline & $291-1$ & $24-\mathrm{C}$ & 2 & 29 & 13 & 2 & 5 & 4 & 29 & $\mathrm{X}$ & complete \\
\hline & $310-4$ & $* * *$ & 2 & 19 & 14 & 2 & 5 & 6 & 14 & $\mathrm{X}$ & straight base, complete \\
\hline
\end{tabular}

* Key to types of breakage patterns:

$\mathrm{X}=$ complete point

$\mathrm{A}=$ direct impact break at the tip, barbs, or base (often appears as a "burin-like" break, though more commonly as a flute-like flake extending from the tip down one face of the point)

$\mathrm{B}=$ snap or bending fracture probably caused by impact on used points or manufacturing mistakes on preforms

$\mathrm{C}=$ burned (usually marked by crazing fractures and pot lid fractures on the artifact)

$\mathrm{D}=$ reworked tip or blade

Points with more than one break were labeled accordingly; e.g. if evidence for both direct impact and snap break was observed, the breakage pattern was coded as A/B.

** Lot No. 288 contains artifacts for which the unit number was eroded and could not be read.

*** Lot No. 310 contains artifacts from other work at Spring Lake. See end note, Chapter 3. 
Appendix B. Projectile Point Fragments

\begin{tabular}{|c|c|c|c|c|c|c|c|c|c|c|}
\hline $\begin{array}{l}\text { Spec. } \\
\text { No. }\end{array}$ & Unit & Level & $\begin{array}{l}\text { Length } \\
\text { (mm) }\end{array}$ & $\begin{array}{l}\text { Width } \\
(\mathrm{mm})\end{array}$ & $\begin{array}{l}\text { Thick- } \\
\text { ness } \\
(\mathrm{mm})\end{array}$ & $\begin{array}{c}\text { Stem } \\
\text { Length } \\
\text { (mm) }\end{array}$ & $\begin{array}{c}\text { Stem } \\
\text { Width } \\
(\mathrm{mm})\end{array}$ & $\begin{array}{c}\text { Base } \\
\text { Width } \\
(\mathrm{mm})\end{array}$ & $\begin{array}{l}\text { Break } \\
\text { Type* }\end{array}$ & Notes, Comments \\
\hline \multicolumn{11}{|c|}{ DART POINT FRAGMENTS } \\
\hline $4-1$ & $14-\mathrm{I}$ & 1 & $74+$ & 27 & 7.5 & & & & $\mathrm{~A}$ & Paleoindian (Scottsbluff?) \\
\hline $5-1$ & $22-\mathrm{B}$ & $3 \& 4$ & $62+$ & $32+$ & 8 & & & & $\mathrm{~B}$ & ET? pressure bevel on right \\
\hline $9-2$ & $27-\mathrm{G}$ & 2 & 36.5 & 25 & 8.5 & & & & $\mathrm{~B}$ & point \\
\hline $11-2$ & $37-\mathrm{V}$ & 2 & 14 & 24 & 4.5 & & & & $\mathrm{C}$ & badly burned \\
\hline $17-2$ & $39-\mathrm{S}$ & 1 & $45.5+$ & $32+$ & 8 & & & & $\mathrm{~A}$ & $\begin{array}{l}\text { breaks tip and basal, prob- } \\
\text { ably from a finished dart point }\end{array}$ \\
\hline $20-3$ & $26-\mathrm{C}$ & 5 & $19+$ & $31+$ & 8.5 & & & & $\mathrm{~B} / \mathrm{B}$ & plano convex \\
\hline $23-2$ & 26-D & 5 & $68+$ & $24+$ & 9 & & & & $\mathrm{~A}$ & distal tip, preform fragment \\
\hline $23-7$ & $26-\mathrm{D}$ & 5 & $31+$ & $38.5+$ & 7 & & & & B & point \\
\hline $25-2$ & $28-\mathrm{E}$ & 5 & $29+$ & $19+$ & 4 & & & & B & point \\
\hline $25-3$ & $28-\mathrm{E}$ & 5 & $27+$ & $29+$ & 5.5 & & & & $\mathrm{~B}$ & point \\
\hline $30-2$ & $27-\mathrm{H}$ & 4 & 23 & 6 & 21 & & & & $\mathrm{~B} / \mathrm{C}$ & $\begin{array}{l}\text { possible Scottsbluff, ground } \\
\text { stem }\end{array}$ \\
\hline $31-1$ & $30-\mathrm{W}$ & 1 & $40.5+$ & $42+$ & $6+$ & & & & B & preform distal \\
\hline $36-1$ & $28-\mathrm{I}$ & 2 & $45+$ & $20+$ & 4.5 & & & & B & point tip, thin distal \\
\hline $37-2$ & $28-\mathrm{I}$ & 1 & $27.4+$ & $27+$ & $7+$ & & & & B & medial of dart point \\
\hline $38-1$ & $28-\mathrm{C}$ & 2 & $39+$ & $21+$ & $7+$ & & & & B & distal, one edge beveled \\
\hline $39-2$ & $28-\mathrm{C}$ & 5 & 35 & 25 & 6 & & & & B & point \\
\hline $39-3$ & $28-\mathrm{C}$ & 5 & 41 & 30 & 5 & & & & B & preform \\
\hline
\end{tabular}

* Types of breakage patterns were coded as follows: X indicates the point is complete; A, direct impact break at the tip, barbs, or base (often appears as a "burin-like" break, though more commonly as a flute-like flake extending from the tip down one face of the point); B, snap or bending fracture probably caused by impact on used points or manufacturing mistakes on preforms; C, burned (usually marked by crazing fractures and pot lid fractures on the artifact); D, reworked tip or blade. Points with more than one of these attributes were labeled accordingly; e.g. if evidence for both direct impact and snap break was observed, the breakage pattern was coded as A/B.

** Lot No. 288 contains artifacts for which the unit number was eroded and could not be read.

$* * *$ Lot No. 309 includes artifacts without provenience or whose unit information is illegible. 
Appendix B. Projectile Point Fragments, continued

\begin{tabular}{|c|c|c|c|c|c|c|c|c|c|c|}
\hline $\begin{array}{l}\text { Spec. } \\
\text { No. }\end{array}$ & Unit & Level & $\begin{array}{c}\text { Length } \\
(\mathrm{mm})\end{array}$ & $\begin{array}{l}\text { Width } \\
(\mathrm{mm})\end{array}$ & $\begin{array}{c}\text { Thick- } \\
\text { ness } \\
(\mathrm{mm})\end{array}$ & $\begin{array}{c}\text { Stem } \\
\text { Length } \\
(\mathrm{mm})\end{array}$ & $\begin{array}{l}\text { Stem } \\
\text { Width } \\
(\mathrm{mm})\end{array}$ & $\begin{array}{c}\text { Base } \\
\text { Width } \\
(\mathrm{mm})\end{array}$ & $\begin{array}{l}\text { Break } \\
\text { Type* }\end{array}$ & Notes, Comments \\
\hline $40-1$ & $28-\mathrm{C}$ & 6 & $9+$ & $13+$ & $5+$ & & & & $\mathrm{C}$ & $\begin{array}{l}\text { unknown, badly burned piece } \\
\text { of a biface }\end{array}$ \\
\hline $41-1$ & $28-\mathrm{B}$ & 1 & $20+$ & $20+$ & $4+$ & & & & $\mathrm{B}$ & medial \\
\hline $42-2$ & $28-\mathrm{B}$ & 3 & $27+$ & $17+$ & $4.5^{+}$ & & & & $\mathrm{B}$ & $\begin{array}{l}\text { thin distal tip, probably a } \\
\text { small dart point tip }\end{array}$ \\
\hline $43-1$ & $28-\mathrm{B}$ & 4 & $18+$ & $27+$ & $4+$ & & & & $\mathrm{C}$ & $\begin{array}{l}\text { corner notched dart point } \\
\text { heavily burned, potlids }\end{array}$ \\
\hline $45-1$ & $28-\mathrm{F}$ & 5 & $42+$ & $20+$ & $7+$ & & & & $\mathrm{C}$ & distal \\
\hline $48-1$ & $29-\mathrm{F}$ & 5 & $11+$ & $24+$ & $4.5^{+}$ & & & & B & $\begin{array}{l}\text { basal, might be Wilson given } \\
\text { dulled edges }\end{array}$ \\
\hline $53-3$ & $29-\mathrm{H}$ & 5 & $49+$ & $20+$ & $5+$ & & & & $\mathrm{B} / \mathrm{C}$ & distal \\
\hline $54-1$ & $27-\mathrm{H}$ & 2 & 49 & 22 & 7 & & & & $\mathrm{C}$ & $\begin{array}{l}\text { burned, can't type due to heat } \\
\text { damage }\end{array}$ \\
\hline $54-2$ & $27-\mathrm{H}$ & 2 & $32+$ & $29+$ & 9 & & & & $\mathrm{~B}$ & distal \\
\hline $57-1$ & $30-\mathrm{G}$ & 6 & $44+$ & $26+$ & 7 & & & & $\mathrm{C}$ & $\begin{array}{l}\text { distal, crude preform, heavily } \\
\text { burned }\end{array}$ \\
\hline $57-2$ & $30-\mathrm{G}$ & 6 & $35+$ & 28 & 6.5 & & & & $\mathrm{~B}, \mathrm{C}$ & medial \\
\hline $60-1$ & $26-\mathrm{B}$ & 5 & 26 & 21 & 6 & & & & $\mathrm{C}$ & $\begin{array}{l}\text { unknown piece of heavily } \\
\text { burned biface }\end{array}$ \\
\hline $60-2$ & $26-\mathrm{B}$ & 5 & $35.5+$ & $25+$ & 5 & & & & B & $\begin{array}{l}\text { distal, thin tip, probably } \mathrm{Pa}- \\
\text { leoindian, parallel flaking }\end{array}$ \\
\hline $61-1$ & $26-\mathrm{E}$ & 3 & $33+$ & 34 & 9 & & & & B & distal \\
\hline 64-1 & $26-\mathrm{F}$ & 5 & $19+$ & $16+$ & $4+$ & & & & $\mathrm{C}$ & medial of dart point \\
\hline \multicolumn{11}{|c|}{$\begin{array}{l}\text { * Types of breakage patterns were coded as follows: X indicates the point is complete; A, direct impact break at the tip, barbs, or base (often appears as a "burin-like" break, } \\
\text { though more commonly as a flute-like flake extending from the tip down one face of the point); B, snap or bending fracture probably caused by impact on used points or } \\
\text { manufacturing mistakes on preforms; C, burned (usually marked by crazing fractures and pot lid fractures on the artifact); D, reworked tip or blade. Points with more than } \\
\text { one of these attributes were labeled accordingly; e.g. if evidence for both direct impact and snap break was observed, the breakage pattern was coded as A/B. }\end{array}$} \\
\hline$* *$ Lot No. & & & ich the unit $\mathrm{r}$ & Imber was e & oded and cou & & & & & \\
\hline & & & & & & & & & & \\
\hline
\end{tabular}


Appendix B. Projectile Point Fragments, continued

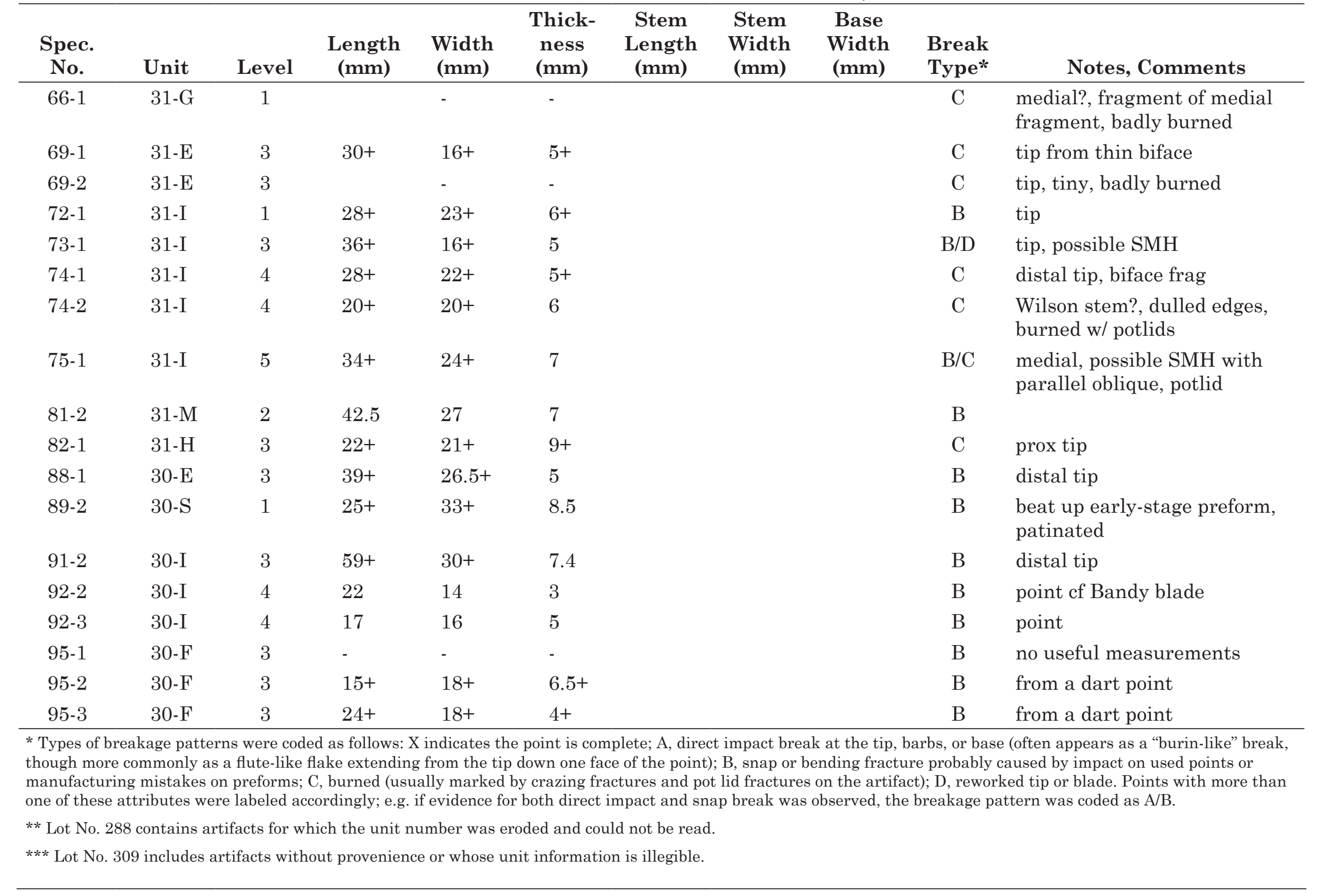


Appendix B. Projectile Point Fragments, continued

\begin{tabular}{|c|c|c|c|c|c|c|c|c|c|c|}
\hline $\begin{array}{l}\text { Spec. } \\
\text { No. }\end{array}$ & Unit & Level & $\begin{array}{c}\text { Length } \\
(\mathrm{mm})\end{array}$ & $\begin{array}{c}\text { Width } \\
(\mathrm{mm})\end{array}$ & $\begin{array}{c}\text { Thick- } \\
\text { ness } \\
(\mathrm{mm})\end{array}$ & $\begin{array}{c}\text { Stem } \\
\text { Length } \\
(\mathrm{mm})\end{array}$ & $\begin{array}{l}\text { Stem } \\
\text { Width } \\
(\mathrm{mm})\end{array}$ & $\begin{array}{c}\text { Base } \\
\text { Width } \\
(\mathrm{mm})\end{array}$ & $\begin{array}{l}\text { Break } \\
\text { Type* }\end{array}$ & Notes, Comments \\
\hline $99-2$ & $30-\mathrm{G}$ & 2 & $30+$ & $30+$ & $9.5+$ & & & & $\mathrm{B}$ & thin, from a dart point \\
\hline $99-3$ & $30-\mathrm{G}$ & 2 & $64+$ & $30+$ & 8 & & & & $\mathrm{C}$ & tip of late preform, potlid \\
\hline $100-2$ & $30-\mathrm{G}$ & 3 & $25+$ & $27+$ & $20+$ & & & & $\mathrm{B}$ & probably from a dart point \\
\hline $100-3$ & $30-\mathrm{G}$ & 3 & $17+$ & - & - & & & & $\mathrm{C}$ & $\begin{array}{l}\text { tiny distal tip, perhaps from } \\
\text { dart point; no useful measure- } \\
\text { ments }\end{array}$ \\
\hline $100-4$ & $30-\mathrm{G}$ & 3 & $24+$ & $24+$ & $26+$ & & & & $\mathrm{B}$ & base \\
\hline $101-1$ & $30-\mathrm{G}$ & 4 & $59+$ & $35+$ & 8 & & & & $\mathrm{~B}$ & \\
\hline $102-1$ & $30-\mathrm{G}$ & 5 & $33+$ & $26+$ & 5 & & & & $\mathrm{~B}$ & \\
\hline $102-2$ & $30-\mathrm{G}$ & 5 & $20+$ & $24+$ & $4.5+$ & & & & $\mathrm{B}$ & \\
\hline $103-2$ & $30-W$ & 3 & $50+$ & $34+$ & 8 & & & & $\mathrm{~B}$ & from a dart point \\
\hline $107-1$ & $25-\mathrm{C}$ & 4 & $32+$ & $20+$ & 7 & & & & $\mathrm{C}$ & prox crude, heavily burned \\
\hline $109-3$ & $25-\mathrm{F}$ & 5 & $29+$ & $20+$ & 4 & & & & B & distal lacks tip \\
\hline $109-4$ & $25-\mathrm{F}$ & 5 & $53+$ & 22 & 7 & & & & $\mathrm{~B}$ & \\
\hline $110-1$ & $29-\mathrm{U}$ & 3 & $32+$ & $30+$ & 4.5 & & & & $\mathrm{~B}$ & thin, from a dart point \\
\hline $115-1$ & 29-I & 3 & $13+$ & $20+$ & $5+$ & & & & B & $\begin{array}{l}\text { damaged stem, probably Ped- } \\
\text { ernales }\end{array}$ \\
\hline $117-2$ & $29-\mathrm{H}$ & 6 & $30+$ & $13+$ & 4 & & & & $\mathrm{~B}$ & distal dart point \\
\hline $117-3$ & $29-\mathrm{H}$ & 6 & $48+$ & $24+$ & 5 & & & & $\mathrm{~B}$ & distal, dart point \\
\hline $119-1$ & $29-\mathrm{F}$ & 3 & $37+$ & $37+$ & 5 & & & & $\mathrm{~B}$ & $\begin{array}{l}\text { medial, thin, probably final } \\
\text { stage preform }\end{array}$ \\
\hline \multicolumn{11}{|c|}{$\begin{array}{l}\text { * Types of breakage patterns were coded as follows: } \mathrm{X} \text { indicates the point is complete; A, direct impact break at the tip, barbs, or base (often appears as a "burin-like" break, } \\
\text { though more commonly as a flute-like flake extending from the tip down one face of the point); B, snap or bending fracture probably caused by impact on used points or } \\
\text { manufacturing mistakes on preforms; C, burned (usually marked by crazing fractures and pot lid fractures on the artifact); D, reworked tip or blade. Points with more than } \\
\text { one of these attributes were labeled accordingly; e.g. if evidence for both direct impact and snap break was observed, the breakage pattern was coded as A/B. }\end{array}$} \\
\hline \multicolumn{11}{|c|}{ ** Lot No. 288 contains artifacts for which the unit number was eroded and could not be read. } \\
\hline *** Lot No & includes & tifacts wit & ut provenien & or whose & $\ldots$ & & & & & \\
\hline
\end{tabular}




\section{Appendix B. Projectile Point Fragments, continued}

\begin{tabular}{|c|c|c|c|c|c|c|c|c|c|c|}
\hline $\begin{array}{l}\text { Spec. } \\
\text { No. }\end{array}$ & Unit & Level & $\begin{array}{l}\text { Length } \\
(\mathrm{mm})\end{array}$ & $\begin{array}{l}\text { Width } \\
\text { (mm) }\end{array}$ & $\begin{array}{l}\text { Thick- } \\
\text { ness } \\
(\mathrm{mm})\end{array}$ & $\begin{array}{c}\text { Stem } \\
\text { Length } \\
(\mathrm{mm})\end{array}$ & $\begin{array}{l}\text { Stem } \\
\text { Width } \\
(\mathrm{mm})\end{array}$ & $\begin{array}{c}\text { Base } \\
\text { Width } \\
\text { (mm) }\end{array}$ & $\begin{array}{l}\text { Break } \\
\text { Type* }\end{array}$ & Notes, Comments \\
\hline $122-1$ & $29-\mathrm{G}$ & 4 & $51+$ & $20+$ & $5.5+$ & & & & $\mathrm{E}$ & $\begin{array}{l}\text { distal tip, preform broken in } \\
\text { manufacture? }\end{array}$ \\
\hline $123-1$ & $29-\mathrm{G}$ & 3 & $23+$ & $36+$ & 10.5 & & & & $\mathrm{~B}$ & $\begin{array}{l}\text { medial, crude, frag, early } \\
\text { stage preform }\end{array}$ \\
\hline $124-1$ & $29-\mathrm{G}$ & 5 & $54+$ & $23+$ & 7.5 & & & & B & distal, ?SMH final preform \\
\hline $125-1$ & 27-D & 4 & $18+$ & $21+$ & $5+$ & & & & $\mathrm{B} / \mathrm{C}$ & crude distal \\
\hline $126-1$ & 27-J & 2 & $23+$ & $20+$ & 4 & & & & $\mathrm{~B}$ & $\begin{array}{l}\text { distal thin, with some parallel } \\
\text { oblique flakes }\end{array}$ \\
\hline $127-1$ & $27-\mathrm{E}$ & 2 & $33+$ & $22+$ & 5 & & & & $\mathrm{C}$ & distal tip of point? \\
\hline $129-1$ & $27-\mathrm{E}$ & 5 & $34+$ & $19+$ & $5+$ & & & & $\mathrm{C}$ & burned distal of a point \\
\hline $131-3$ & $27-\mathrm{C}$ & 4 & $23+$ & $17+$ & $3+$ & & & & B & small distal tip of dart point? \\
\hline $134-1$ & $27-\mathrm{I}$ & 3 & $25+$ & $18+$ & $4.5^{+}$ & & & & B & distal tip of a dart point \\
\hline $135-1$ & $27-\mathrm{I}$ & 3 & $25+$ & $13+$ & 4 & & & & B & distal tip \\
\hline $137-2$ & $27-\mathrm{K}$ & 3 & $66+$ & 26 & 8 & & & & $\mathrm{C}$ & base burned \\
\hline $138-1$ & $27-\mathrm{G}$ & 6 & 33 & 21 & 6.5 & & & & B & untyped fragment \\
\hline $140-1$ & $27-\mathrm{F}$ & 3 & $19+$ & $42+$ & $5+$ & & & & $\mathrm{C}$ & $\begin{array}{l}\text { heavily burned, medial of } \\
\text { wide late stage preform? }\end{array}$ \\
\hline $140-2$ & $27-\mathrm{F}$ & 3 & $26+$ & $24+$ & 6.5 & & & & $\mathrm{~B}$ & $\begin{array}{l}\text { medial, probably from a dart } \\
\text { point }\end{array}$ \\
\hline $141-3$ & $27-\mathrm{F}$ & 5 & $25^{+}$ & $23.5+$ & $6+$ & & & & $\mathrm{B}$ & $\begin{array}{l}\text { dart point stem, probably } \\
\text { Nolan }\end{array}$ \\
\hline $145-1$ & $27-\mathrm{B}$ & 5 & $23+$ & $18+$ & 5 & & & & $\mathrm{~B}$ & biface edge frag \\
\hline
\end{tabular}

* Types of breakage patterns were coded as follows: X indicates the point is complete; A, direct impact break at the tip, barbs, or base (often appears as a "burin-like" break, though more commonly as a flute-like flake extending from the tip down one face of the point); B, snap or bending fracture probably caused by impact on used points or manufacturing mistakes on preforms; C, burned (usually marked by crazing fractures and pot lid fractures on the artifact); D, reworked tip or blade. Points with more than one of these attributes were labeled accordingly; e.g. if evidence for both direct impact and snap break was observed, the breakage pattern was coded as A/B.

** Lot No. 288 contains artifacts for which the unit number was eroded and could not be read.

*** Lot No. 309 includes artifacts without provenience or whose unit information is illegible. 
Appendix B. Projectile Point Fragments, continued

\begin{tabular}{|c|c|c|c|c|c|c|c|c|c|c|}
\hline $\begin{array}{l}\text { Spec. } \\
\text { No. }\end{array}$ & Unit & Level & $\begin{array}{l}\text { Length } \\
(\mathrm{mm})\end{array}$ & $\begin{array}{l}\text { Width } \\
(\mathrm{mm})\end{array}$ & $\begin{array}{l}\text { Thick- } \\
\text { ness } \\
(\mathrm{mm})\end{array}$ & $\begin{array}{c}\text { Stem } \\
\text { Length } \\
\text { (mm) }\end{array}$ & $\begin{array}{c}\text { Stem } \\
\text { Width } \\
(\mathrm{mm})\end{array}$ & $\begin{array}{c}\text { Base } \\
\text { Width } \\
(\mathbf{m m})\end{array}$ & $\begin{array}{l}\text { Break } \\
\text { Type* }\end{array}$ & Notes, Comments \\
\hline $146-1$ & $27-\mathrm{G}$ & 2 & $30+$ & $30+$ & $5+$ & & & & $\mathrm{C}$ & $\begin{array}{l}\text { medial, with } 1 \text { barb } \\
\text { (= stemmed pt) }\end{array}$ \\
\hline $146-2$ & $27-\mathrm{G}$ & 2 & $20+$ & $25+$ & 3.5 & & & & $\mathrm{C}$ & medial from a thin dart point \\
\hline $147-1$ & $27-G$ & 3 & $38+$ & $28+$ & 7 & & & & $\mathrm{~B}$ & distal, thin dart point? \\
\hline $149-1$ & $23-\mathrm{E}$ & 1 & $30+$ & $22+$ & 6.5 & & & & $\mathrm{C}$ & distal frag of a dart point \\
\hline $149-2$ & $23-\mathrm{E}$ & 1 & $30+$ & 24 & 9 & & & & B & distal tip \\
\hline $153-1$ & $23-\mathrm{B}$ & 1 & $36+$ & $20+$ & $6+$ & & & & B & distal, thin, dart point \\
\hline $159-1$ & $33-\mathrm{T}$ & 1 & $47+$ & $38+$ & 6 & & & & $\mathrm{C}$ & $\begin{array}{l}\text { probably burned dart point, } \\
\text { one barb remains }\end{array}$ \\
\hline $161-2$ & $33-\mathrm{Q}$ & 2 & $53+$ & 34 & 11 & & & & B & $\begin{array}{l}\text { expanding stemmed point, } \\
\text { broken in manufacture }\end{array}$ \\
\hline $162-1$ & $33-\mathrm{U}$ & 1 & $26+$ & $20+$ & $6+$ & & & & $\mathrm{B}$ & distal tip from dart point \\
\hline $163-1$ & $33-\mathrm{X}$ & 1 & $36+$ & $20+$ & $6+$ & & & & $\mathrm{A} / \mathrm{B}$ & distal tip from dart point \\
\hline $173-1$ & $22-\mathrm{B}$ & 1 & 23 & 19 & 7 & & & & $\mathrm{~A}$ & severe impact both ends \\
\hline $175-2$ & $22-\mathrm{C}$ & 2 & $50+$ & $27+$ & $7+$ & & & & B & distal tip of dart point \\
\hline $178-2$ & $22-\mathrm{G}$ & 3 & $19+$ & $30+$ & $7.5^{+}$ & & & & $\mathrm{C}$ & medial heavily burned \\
\hline $179-1$ & $22-\mathrm{A}$ & 1 & 61.5 & 22 & 7 & & & & B & distal tip \\
\hline $180-2$ & $22-\mathrm{D}$ & 1 & $38+$ & $17+$ & $4+$ & & & & B & thin distal tip \\
\hline $180-3$ & $22-\mathrm{D}$ & 1 & $55+$ & $21+$ & $8+$ & & & & $\mathrm{E}$ & split/splintered biface frag \\
\hline $191-1$ & $19-\mathrm{A}$ & 1 & $56+$ & 35 & 9 & & & & B & \\
\hline $192-1$ & 19-A & 3 & 45 & 34 & $8+$ & & & & $\mathrm{C}$ & dart point fragment \\
\hline $198-2$ & $21-\mathrm{G}$ & 2 & $33+$ & $30+$ & 5 & & & & $\mathrm{~B}$ & \\
\hline \multicolumn{11}{|c|}{$\begin{array}{l}\text { * Types of breakage patterns were coded as follows: X indicates the point is complete; A, direct impact break at the tip, barbs, or base (often appears as a "burin-like" break, } \\
\text { though more commonly as a flute-like flake extending from the tip down one face of the point); B, snap or bending fracture probably caused by impact on used points or } \\
\text { manufacturing mistakes on preforms; C, burned (usually marked by crazing fractures and pot lid fractures on the artifact); D, reworked tip or blade. Points with more than } \\
\text { one of these attributes were labeled accordingly; e.g. if evidence for both direct impact and snap break was observed, the breakage pattern was coded as A/B. }\end{array}$} \\
\hline ** Lot No. & contains & $f_{a p t a} f \circ \mathrm{w}$ & Sh th & mber was e & ded and co & A & & & & \\
\hline
\end{tabular}


Appendix B. Projectile Point Fragments, continued

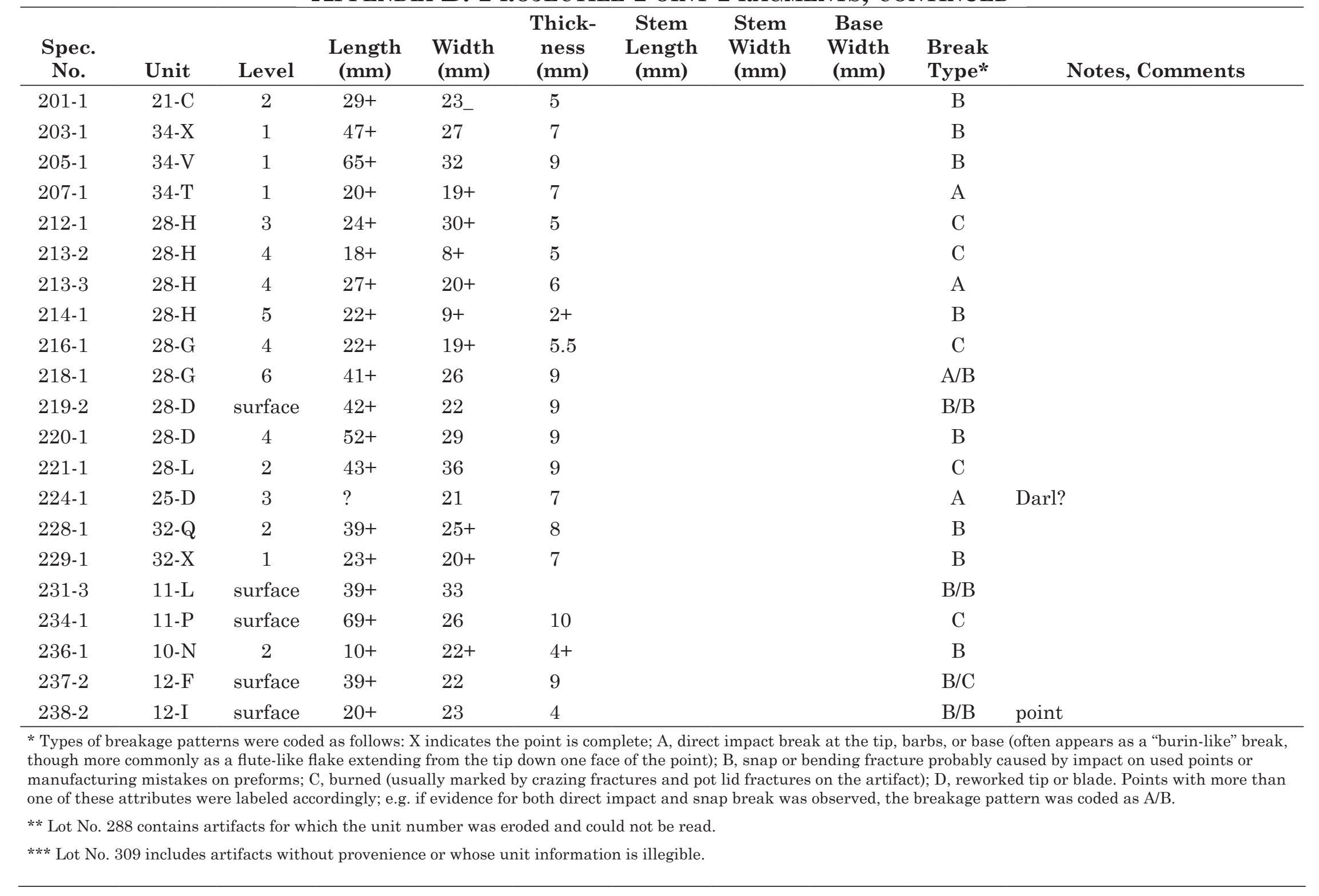


Appendix B. Projectile Point Fragments, continued

\begin{tabular}{|c|c|c|c|c|c|c|c|c|c|c|}
\hline $\begin{array}{l}\text { Spec. } \\
\text { No. }\end{array}$ & Unit & Level & $\begin{array}{c}\text { Length } \\
(\mathrm{mm})\end{array}$ & $\begin{array}{l}\text { Width } \\
(\mathrm{mm})\end{array}$ & $\begin{array}{l}\text { Thick- } \\
\text { ness } \\
(\mathrm{mm})\end{array}$ & $\begin{array}{l}\text { Stem } \\
\text { Length } \\
(\mathrm{mm})\end{array}$ & $\begin{array}{c}\text { Stem } \\
\text { Width } \\
(\mathrm{mm})\end{array}$ & $\begin{array}{c}\text { Base } \\
\text { Width } \\
(\mathrm{mm})\end{array}$ & $\begin{array}{l}\text { Break } \\
\text { Type* }\end{array}$ & Notes, Comments \\
\hline $245-1$ & $16-\mathrm{A}$ & 2 & $16+$ & $\mathrm{n} / \mathrm{a}$ & 5 & & & & $\mathrm{C}$ & base/not Pedernales \\
\hline $253-1$ & $15-\mathrm{N}$ & surface & $41+$ & 38 & 6 & & & & $\mathrm{~B} / \mathrm{B}$ & \\
\hline 254-1 & $15-\mathrm{O}$ & surface & $18+$ & $25+$ & 7 & & & & $\mathrm{C}$ & oblique-parallel, right bevel \\
\hline $262-1$ & $35-\mathrm{W}$ & 2 & $27+$ & $\mathrm{n} / \mathrm{a}$ & 9 & & & & $\mathrm{C}$ & ground base \\
\hline $263-1$ & $35-\mathrm{X}$ & 1 & 47 & 35 & 5 & & & & & dart point fragment \\
\hline $268-2$ & $36-\mathrm{W}$ & 1 & $31_{-}$ & 24 & 5 & & & & B & \\
\hline $268-3$ & $36-\mathrm{W}$ & 1 & $36+$ & 35 & 6 & & & & $\mathrm{~B}$ & \\
\hline $273-1$ & $38-\mathrm{S}$ & 2 & $38+$ & 22 & 7 & & & & $\mathrm{~A} / \mathrm{B}$ & possible Paleoindian \\
\hline $274-2$ & $38-\mathrm{T}$ & 3 & $35+$ & 23 & 6 & & & & $\mathrm{~B} / \mathrm{D}$ & $\begin{array}{l}\text { beveled right, probably Paleo- } \\
\text { indian }\end{array}$ \\
\hline $279-1$ & $39-\mathrm{T}$ & 2 & 42 & 31 & 6 & & & & $\mathrm{~A}$ & \\
\hline $282-1$ & $39-W$ & 1 & 43 & 26 & $6+$ & & & & $\mathrm{C}$ & \\
\hline $282-2$ & $39-\mathrm{W}$ & 1 & $50+$ & $36+$ & 9 & & & & $\mathrm{~A} / \mathrm{B}$ & $\begin{array}{l}\text { parallel flaking, Paleoindian } \\
\text { point }\end{array}$ \\
\hline $284-1$ & $26-\mathrm{C}$ & 1 & $67+$ & 33 & 9 & & & & B & \\
\hline $285-1$ & $26-\mathrm{C}$ & 3 & $50+$ & 43 & 7 & & & & $\mathrm{~B}$ & \\
\hline $286-1$ & $31-\mathrm{E}$ & 1 & $15+$ & 16 & 5 & & & & $\mathrm{~A} / \mathrm{B}$ & \\
\hline $287-1$ & $37-\mathrm{V}$ & 7 & $44+$ & $23+$ & 10 & & & & $\mathrm{~B} / \mathrm{B}$ & point or preform \\
\hline $288-10$ & $* *$ & & $50+$ & $30+$ & 6 & & & & B & \\
\hline $288-11$ & $* *$ & & $38+$ & 26 & 6 & & & & B & \\
\hline 288-19 & $* *$ & & $50+$ & $36+$ & 6 & & & & B & mfg mistake \\
\hline \multicolumn{11}{|c|}{$\begin{array}{l}\text { * Types of breakage patterns were coded as follows: } \mathrm{X} \text { indicates the point is complete; A, direct impact break at the tip, barbs, or base (often appears as a "burin-like" break, } \\
\text { though more commonly as a flute-like flake extending from the tip down one face of the point); B, snap or bending fracture probably caused by impact on used points or } \\
\text { manufacturing mistakes on preforms; C, burned (usually marked by crazing fractures and pot lid fractures on the artifact); D, reworked tip or blade. Points with more than } \\
\text { one of these attributes were labeled accordingly; e.g. if evidence for both direct impact and snap break was observed, the breakage pattern was coded as A/B. }\end{array}$} \\
\hline ** Lot No. & contains & ifacts for w & ch the unit $n$ & mber was & ded and co & d not be rea & & & & \\
\hline
\end{tabular}




\section{Appendix B. Projectile Point Fragments, continued}

\begin{tabular}{|c|c|c|c|c|c|c|c|c|c|c|}
\hline $\begin{array}{l}\text { Spec. } \\
\text { No. }\end{array}$ & Unit & Level & $\begin{array}{l}\text { Length } \\
(\mathrm{mm})\end{array}$ & $\begin{array}{l}\text { Width } \\
(\mathrm{mm})\end{array}$ & $\begin{array}{l}\text { Thick- } \\
\text { ness } \\
(\mathrm{mm})\end{array}$ & $\begin{array}{l}\text { Stem } \\
\text { Length } \\
\text { (mm) }\end{array}$ & $\begin{array}{c}\text { Stem } \\
\text { Width } \\
(\mathrm{mm})\end{array}$ & $\begin{array}{c}\text { Base } \\
\text { Width } \\
(\mathrm{mm})\end{array}$ & $\begin{array}{l}\text { Break } \\
\text { Type* }\end{array}$ & Notes, Comments \\
\hline $288-21$ & $* *$ & & $27+$ & $7+$ & $4+$ & & & & $\mathrm{C}$ & \\
\hline $288-22$ & $* *$ & & $42+$ & 30 & 6 & & & & B & \\
\hline $288-37$ & $* *$ & & $26+$ & $23+$ & $5+$ & & & & B & \\
\hline $288-42$ & $* *$ & & $21+$ & $19+$ & $5+$ & & & & $\mathrm{C}$ & \\
\hline $288-43$ & $* *$ & & 32 & 24 & 7 & & & & $?$ & \\
\hline $288-49$ & $* *$ & & $37+$ & $18+$ & $6+$ & & & & B & \\
\hline $288-50$ & $* *$ & & $25+$ & $14+$ & 4 & & & & B & \\
\hline $288-51$ & $* *$ & & $26+$ & $16+$ & $4+$ & & & & $\mathrm{B}$ & \\
\hline $288-52$ & $* *$ & & $34+$ & $27+$ & 7 & & & & B & \\
\hline $288-54$ & $* *$ & & $17+$ & $12+$ & $4+$ & & & & $\mathrm{C}$ & \\
\hline $288-55$ & $* *$ & & $25+$ & $19+$ & 6 & & & & $\mathrm{C}$ & \\
\hline $288-7$ & $* *$ & & $70+$ & $35+$ & 8 & & & & B & stem missing \\
\hline $307-1$ & $16-\mathrm{K}$ & & $35+$ & 24 & 7 & & & & B & $\begin{array}{l}\text { parallel flaking, Paleoindian } \\
\text { point }\end{array}$ \\
\hline $309-1$ & $* * *$ & & $18+$ & $20+$ & 5 & & & & B & \\
\hline $309-10$ & $29-?$ & 6 & 21 & 9 & 4 & & & & B & \\
\hline $309-2$ & $* * *$ & & $34+$ & 34 & 6 & & & & $\mathrm{C}$ & \\
\hline $309-3$ & $* * *$ & & $38+$ & 24 & 5 & & & & $\mathrm{C}$ & probably Paleoindian \\
\hline $309-6$ & $* * *$ & & $8+$ & 6 & 2 & & & & $\mathrm{C}$ & \\
\hline $309-7$ & $* * *$ & & 45 & 24 & 11 & & & & B & dart point fragment \\
\hline $309-9$ & $29-?$ & 2 & $19+$ & $29+$ & 7 & & & & $\mathrm{C}$ & \\
\hline \multicolumn{11}{|c|}{$\begin{array}{l}\text { * Types of breakage patterns were coded as follows: } \mathrm{X} \text { indicates the point is complete; A, direct impact break at the tip, barbs, or base (often appears as a "burin-like" break, } \\
\text { though more commonly as a flute-like flake extending from the tip down one face of the point); B, snap or bending fracture probably caused by impact on used points or } \\
\text { manufacturing mistakes on preforms; C, burned (usually marked by crazing fractures and pot lid fractures on the artifact); D, reworked tip or blade. Points with more than } \\
\text { one of these attributes were labeled accordingly; e.g. if evidence for both direct impact and snap break was observed, the breakage pattern was coded as A/B. }\end{array}$} \\
\hline \multicolumn{11}{|c|}{$* *$ Lot No. 288 contains artifacts for which the unit number was eroded and could not be read. } \\
\hline
\end{tabular}


Appendix B. Projectile Point Fragments, continued

\begin{tabular}{|c|c|c|c|c|c|c|c|c|c|c|}
\hline $\begin{array}{l}\text { Spec. } \\
\text { No. }\end{array}$ & Unit & Level & $\begin{array}{c}\text { Length } \\
\text { (mm) }\end{array}$ & $\begin{array}{c}\text { Width } \\
\text { (mm) }\end{array}$ & $\begin{array}{l}\text { Thick- } \\
\text { ness } \\
(\mathrm{mm})\end{array}$ & $\begin{array}{c}\text { Stem } \\
\text { Length } \\
\text { (mm) }\end{array}$ & $\begin{array}{l}\text { Stem } \\
\text { Width } \\
\text { (mm) }\end{array}$ & $\begin{array}{c}\text { Base } \\
\text { Width } \\
(\mathrm{mm})\end{array}$ & $\begin{array}{l}\text { Break } \\
\text { Type* }\end{array}$ & Notes, Comments \\
\hline \multicolumn{11}{|c|}{ ARROW POINT FRAGMENTS } \\
\hline $87-1$ & $30-\mathrm{E}$ & 1 & $25+$ & 21.5 & 4 & & 21 & 21 & B & triangular preform \\
\hline $305-1$ & $14-\mathrm{Q}$ & & $23+$ & 11.5 & 2 & 5 & - & - & $\mathrm{B}$ & stem missing \\
\hline $309-8$ & $31-?$ & 2 & $32+$ & 15 & 2 & - & 6 & & $\mathrm{~B}$ & tip and stem missing \\
\hline \multicolumn{11}{|c|}{$\begin{array}{l}\text { * Types of breakage patterns were coded as follows: X indicates the point is complete; A, direct impact break at the tip, barbs, or base (often appears as a "burin-like" breal } \\
\text { though more commonly as a flute-like flake extending from the tip down one face of the point); B, snap or bending fracture probably caused by impact on used points or } \\
\text { manufacturing mistakes on preforms; C, burned (usually marked by crazing fractures and pot lid fractures on the artifact); D, reworked tip or blade. Points with more thar } \\
\text { one of these attributes were labeled accordingly; e.g. if evidence for both direct impact and snap break was observed, the breakage pattern was coded as A/B. }\end{array}$} \\
\hline \multicolumn{11}{|c|}{ ** Lot No. 288 contains artifacts for which the unit number was eroded and could not be read. } \\
\hline$* * *$ Lot No & includes & tifacts witl & prove & whos & form & is illegible. & & & & \\
\hline
\end{tabular}


Appendix C. Untyped Biface Preforms

\begin{tabular}{|c|c|c|c|c|c|c|c|}
\hline $\begin{array}{c}\text { Spec. } \\
\text { No. }\end{array}$ & Unit & Level & $\begin{array}{c}\text { Length } \\
\text { (mm) }\end{array}$ & $\begin{array}{l}\text { Width } \\
\text { (mm) }\end{array}$ & $\begin{array}{l}\text { Thick- } \\
\text { ness } \\
(\mathrm{mm})\end{array}$ & $\begin{array}{l}\text { Break } \\
\text { Type* }\end{array}$ & Notes, Comments \\
\hline $1-1$ & $23-\mathrm{D}$ & 1 or 2 & 36.5 & 25 & 8.5 & $\mathrm{~B}$ & distal, preform \\
\hline $2-1$ & $12-\mathrm{P}$ & 1 & $54+$ & 24.5 & 6.5 & $\mathrm{~B}$ & probably mid-stage St. Mary's Hall preform \\
\hline $46-1$ & $28-\mathrm{F}$ & 6 & $33+$ & $38+$ & 10 & $\mathrm{C}$ & medial fragment \\
\hline $50-3$ & $29-\mathrm{G}$ & 6 & $43+$ & 33 & 8 & $\mathrm{~B}$ & base/preform, rounded base of crude preform \\
\hline $50-4$ & $29-\mathrm{G}$ & 6 & $45+$ & $43+$ & 8 & $\mathrm{~B}$ & tip, distal, thin \\
\hline $53-2$ & $29-\mathrm{H}$ & 5 & $57+$ & 31 & 9.5 & $\mathrm{~B}$ & preform, proximal, concave base \\
\hline $59-2$ & $26-\mathrm{B}$ & 4 & 54 & 40 & 7 & $\mathrm{~B}$ & distal, knife?, thin \\
\hline $62-1$ & $26-\mathrm{H}$ & 3 & $43+$ & 42 & 9 & $\mathrm{~B}$ & proximal, oval biface, crude \\
\hline $68-2$ & $31-\mathrm{E}$ & & $62+$ & $30+$ & $5.5+$ & $\mathrm{E}$ & distal tip \\
\hline $78-1$ & $31-\mathrm{W}$ & & 71 & 31 & 7.5 & $\mathrm{X}$ & preform, ovate \\
\hline $79-1$ & $31-\mathrm{W}$ & & 42 & 21 & 8 & $\mathrm{X}$ & preform, parallel-sided, maybe Paleoindian, stacks \\
\hline $81-1$ & $31-\mathrm{M}$ & & 62 & 24 & 9 & $\mathrm{X}$ & lanceolate biface preform, stream-rolled \\
\hline $83-2$ & $31-\mathrm{H}$ & 5 & $31+$ & $42+$ & 8 & $\mathrm{~B}$ & fragment, early stage, distal or even basal \\
\hline $84-1$ & $31-\mathrm{H}$ & 6 & $36+$ & $31+$ & 6 & $\mathrm{~B}$ & $\begin{array}{l}\text { preform prox, parallel-sided straight base, mid-late stage } \\
\text { preform }\end{array}$ \\
\hline $93-2$ & $30-\mathrm{F}$ & 1 & $42+$ & $30+$ & 4.5 & $\mathrm{~B}$ & distal tip, preform (first stage) \\
\hline $94-1$ & $30-\mathrm{F}$ & 2 & $44+$ & 30 & 7 & $\mathrm{~B}$ & distal tip, probable preform \\
\hline $96-1$ & $30-\mathrm{F}$ & 5 & $67+$ & $38+$ & $5.5+$ & $\mathrm{B}$ & distal tip of thinned preform \\
\hline $96-2$ & $30-\mathrm{F}$ & 5 & $37+$ & $28+$ & $6.5+$ & $\mathrm{B}$ & distal tip from preform \\
\hline \multicolumn{8}{|c|}{$\begin{array}{l}\text { * Types of breakage patterns were coded as follows: } \mathrm{X} \text { indicates the point is complete; A, direct impact break at the tip, barbs, or base (often appears as a "burin-like" breal } \\
\text { though more commonly as a flute-like flake extending from the tip down one face of the point); B, snap or bending fracture probably caused by impact on used points or } \\
\text { manufacturing mistakes on preforms; C, burned (usually marked by crazing fractures and pot lid fractures on the artifact); D, reworked tip or blade. Points with more thar } \\
\text { one of these attributes were labeled accordingly; e.g. if evidence for both direct impact and snap break was observed, the breakage pattern was coded as A/B. }\end{array}$} \\
\hline \multicolumn{8}{|c|}{ ** Lot No. 288 contains artifacts for which the unit number was eroded and could not be read. } \\
\hline
\end{tabular}


Appendix C. Untyped Biface Preforms, continued

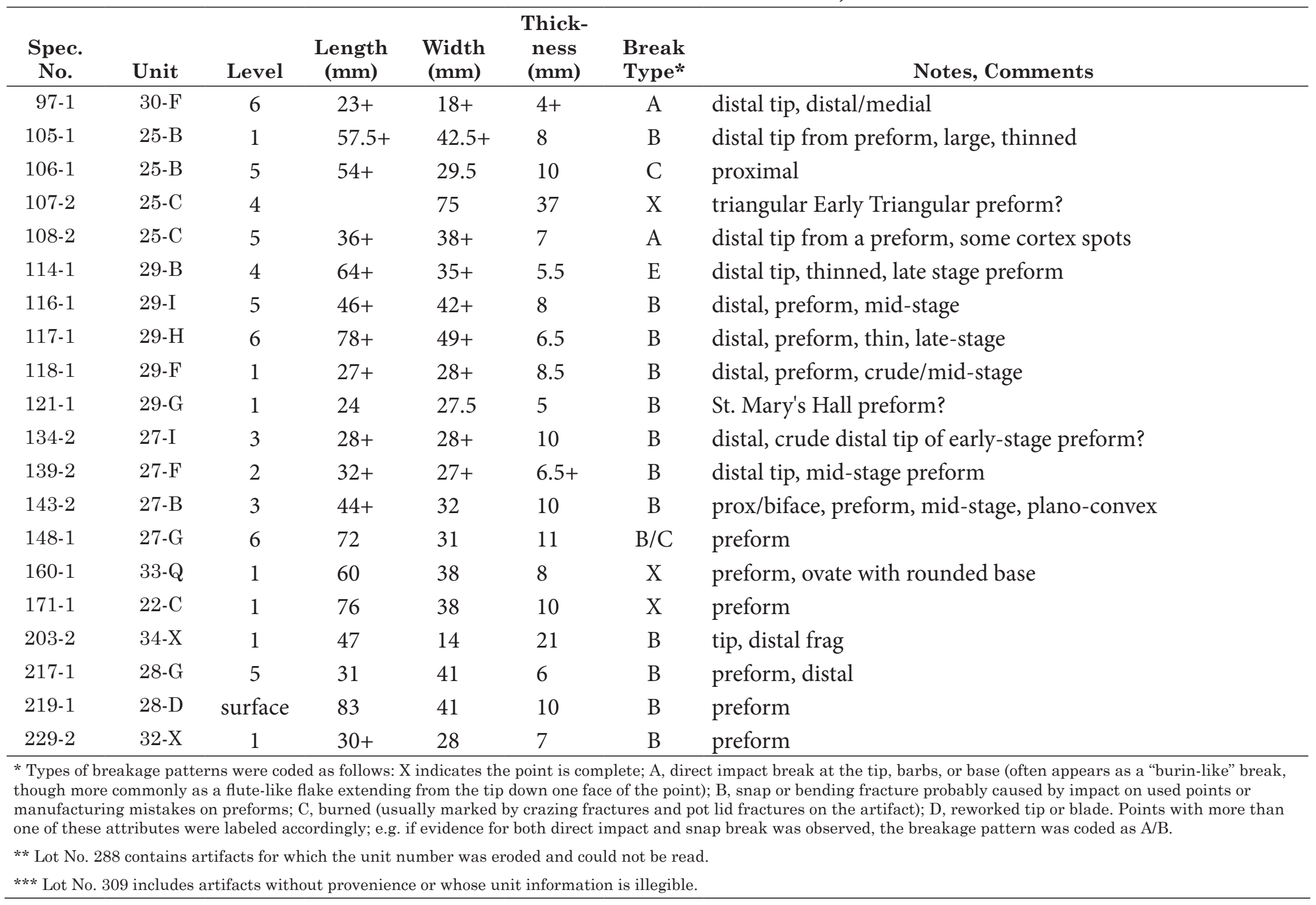


Appendix C. Untyped Biface Preforms, continued

\begin{tabular}{|c|c|c|c|c|c|c|c|}
\hline $\begin{array}{c}\text { Spec. } \\
\text { No. }\end{array}$ & Unit & Level & $\begin{array}{c}\text { Length } \\
\text { (mm) }\end{array}$ & $\begin{array}{c}\text { Width } \\
(\mathrm{mm})\end{array}$ & $\begin{array}{l}\text { Thick- } \\
\text { ness } \\
\text { (mm) }\end{array}$ & $\begin{array}{l}\text { Break } \\
\text { Type* }\end{array}$ & Notes, Comments \\
\hline $248-1$ & 15-J & surface & 87 & 40 & 10 & $\mathrm{X}$ & complete \\
\hline $257-2$ & $14-\mathrm{H}$ & surface & $40+$ & 35 & 9 & B & preform, base \\
\hline $266-1$ & $36-\mathrm{U}$ & 1 & $52+$ & 26 & 7 & B & preform, round base \\
\hline $272-1$ & 38-M & 3 & 29 & 32 & 9 & B & preform, distal \\
\hline $276-1$ & $38-\mathrm{V}$ & 2 & $56+$ & 47 & 11 & $\mathrm{~B}$ & preform, mfg mistake \\
\hline $288-2$ & $* *$ & & $30+$ & 51 & 8 & B & dart point preform \\
\hline $288-12$ & $* *$ & & $49+$ & 41 & 19 & $\mathrm{~B}$ & preform, novice? \\
\hline $288-17$ & $* *$ & & 65 & 35 & 9 & $\mathrm{X}$ & preform, complete, round base \\
\hline $288-30$ & $* *$ & & $37+$ & 32 & 9 & $\mathrm{~B}$ & preform, proximal \\
\hline $288-31$ & $* *$ & & $50+$ & 24 & 7 & $\mathrm{~B}$ & preform, triangular, tip missing \\
\hline $288-35$ & $* *$ & & $40+$ & 25 & 10 & $\mathrm{~B}$ & medial \\
\hline $288-40$ & $* *$ & & $32+$ & $47+$ & 9 & $\mathrm{~B}$ & preform, failure \\
\hline $288-47$ & $* *$ & & 36 & 11 & 5 & $\mathrm{C}$ & preform, proximal end \\
\hline $309-4$ & $* * *$ & & $25+$ & 24 & 8 & B & preform, distal \\
\hline 309-11 & $30 ?$ & 6 & $90+$ & 35 & 10 & $\mathrm{~F}$ & preform \\
\hline \multicolumn{8}{|c|}{$\begin{array}{l}\text { * Types of breakage patterns were coded as follows: X indicates the point is complete; A, direct impact break at the tip, barbs, or base (often appears as a "burin-like" break, } \\
\text { though more commonly as a flute-like flake extending from the tip down one face of the point); B, snap or bending fracture probably caused by impact on used points or } \\
\text { manufacturing mistakes on preforms; C, burned (usually marked by crazing fractures and pot lid fractures on the artifact); D, reworked tip or blade. Points with more than } \\
\text { one of these attributes were labeled accordingly; e.g. if evidence for both direct impact and snap break was observed, the breakage pattern was coded as A/B. } \\
\text { ** Lot No. } 288 \text { contains artifacts for which the unit number was eroded and could not be read. }\end{array}$} \\
\hline
\end{tabular}



Appendix D. Other Tools and Artifacts

\begin{tabular}{|c|c|c|c|c|c|c|c|c|c|c|}
\hline $\begin{array}{l}\text { Spec. } \\
\text { No. }\end{array}$ & Unit & Level & $\begin{array}{l}\text { Length } \\
(\mathrm{mm})\end{array}$ & $\begin{array}{l}\text { Width } \\
(\mathrm{mm})\end{array}$ & $\begin{array}{l}\text { Thick- } \\
\text { ness } \\
(\mathrm{mm})\end{array}$ & $\begin{array}{c}\text { Stem } \\
\text { Length } \\
(\mathrm{mm})\end{array}$ & $\begin{array}{l}\text { Stem } \\
\text { Width } \\
(\mathrm{mm})\end{array}$ & $\begin{array}{c}\text { Bit } \\
\text { Width } \\
(\mathbf{m m})\end{array}$ & $\begin{array}{l}\text { Break } \\
\text { Type* }\end{array}$ & Notes, Comments \\
\hline \multicolumn{11}{|c|}{ MULTI-PURPOSE BIFACE TOOL } \\
\hline $14-1$ & $28-\mathrm{D}$ & 5 & 77 & 28 & 8.5 & 23.5 & & & & $\begin{array}{l}\text { parallel-sided, convex based alt bev } \\
\text { tip angles in, reworked, no dull, "fat } \\
\text { feel" }\end{array}$ \\
\hline \multicolumn{11}{|c|}{ LARGE DRILLS } \\
\hline $7-1$ & $31-\mathrm{R}$ & 1 & $47+$ & 33 & 5 & & & 12 & $\mathrm{~B}$ & \\
\hline $12-1$ & $13-\mathrm{L}$ & 17 & 45.5 & 34 & 9.5 & & & 13 & $\mathrm{X}$ & \\
\hline $18-2$ & $22-\mathrm{O}$ & 1 & $38+$ & 24 & 7 & & & $\mathrm{n} / \mathrm{a}$ & $\mathrm{C}$ & $\begin{array}{l}\text { tip missing plano-convex based, } \\
\text { highly altered }\end{array}$ \\
\hline $36-2$ & $28-\mathrm{I}$ & 2 & $49+$ & $27+$ & 4.5 & & & $\mathrm{n} / \mathrm{a}$ & $\mathrm{B}$ & $\begin{array}{l}\text { bifacial perforator, tip missing, flake } \\
\text { removal damaged base }\end{array}$ \\
\hline $232-1$ & $11-\mathrm{M}$ & surface & 66 & 26 & 9 & & & 10 & $\mathrm{~B}$ & \\
\hline $267-1$ & $36-\mathrm{U}$ & 2 & $32+$ & 31 & 7 & & & 12 & $\mathrm{~B}$ & \\
\hline $281-1$ & $39-\mathrm{V}$ & 1 & $49+$ & 24 & 6 & & & 8 & $\mathrm{C}$ & \\
\hline $288-46$ & $* *$ & & $36+$ & 11 & 5 & & & 11 & $\mathrm{C}$ & bit only \\
\hline \multicolumn{11}{|c|}{ FOUR-EDGE BEVELED KNIFE } \\
\hline $141-5$ & $27-\mathrm{F}$ & 5 & $41+$ & $34+$ & 6 & & & & B & $\begin{array}{l}\text { tip (proximal) to a 4-edge beveled } \\
\text { knife }\end{array}$ \\
\hline \multicolumn{11}{|c|}{ LARGE END SCRAPER } \\
\hline $31-2$ & $30-\mathrm{W}$ & 1 & 72 & 57 & 18 & & & & $\mathrm{X}$ & large end scraper \\
\hline \multicolumn{11}{|c|}{$\begin{array}{l}\text { * Types of breakage patterns were coded as follows: X indicates the point is complete; A, direct impact break at the tip, barbs, or base (often appears as a "burin-like" break } \\
\text { though more commonly as a flute-like flake extending from the tip down one face of the point); B, snap or bending fracture probably caused by impact on used points or } \\
\text { manufacturing mistakes on preforms; C, burned (usually marked by crazing fractures and pot lid fractures on the artifact); D, reworked tip or blade. Points with more than } \\
\text { one of these attributes were labeled accordingly; e.g. if evidence for both direct impact and snap break was observed, the breakage pattern was coded as A/B. } \\
\text { ** Lot No. } 288 \text { contains artifacts for which the unit number was eroded and could not be read. }\end{array}$} \\
\hline
\end{tabular}


Appendix D. Other Tools and Artifacts, continued

\begin{tabular}{|c|c|c|c|c|c|c|c|c|c|c|}
\hline $\begin{array}{l}\text { Spec. } \\
\text { No. }\end{array}$ & Unit & Level & $\begin{array}{l}\text { Length } \\
(\mathrm{mm})\end{array}$ & $\begin{array}{l}\text { Width } \\
(\mathrm{mm})\end{array}$ & $\begin{array}{l}\text { Thick- } \\
\text { ness } \\
(\mathrm{mm})\end{array}$ & $\begin{array}{l}\text { Stem } \\
\text { Length } \\
(\mathbf{m m})\end{array}$ & $\begin{array}{l}\text { Stem } \\
\text { Width } \\
(\mathbf{m m})\end{array}$ & $\begin{array}{l}\text { Bit } \\
\text { Width } \\
(\mathbf{m m})\end{array}$ & $\begin{array}{l}\text { Break } \\
\text { Type* }\end{array}$ & Notes, Comments \\
\hline \multicolumn{11}{|c|}{ SMALL END SCRAPER } \\
\hline $287-2$ & $30-\mathrm{H}$ & 5 & $25+$ & $12+$ & 3 & & & & $\mathrm{X}$ & small end scraper? \\
\hline \multicolumn{11}{|c|}{ CLEAR FORK ADZE } \\
\hline $65-1$ & $26-\mathrm{D}$ & 3 & $38.5+$ & $34+$ & 12 & & & & $\mathrm{~B}$ & prox end, edges dulled \\
\hline $67-1$ & $32-\mathrm{G}$ & 2 & 76 & 37 & 12 & & & & $\mathrm{X}$ & extensive use at bit, edge angle $45-50^{\circ}$ \\
\hline $86-1$ & $30-\mathrm{C}$ & 2 & 93 & 44 & 13 & & & & $\mathrm{X}$ & $\begin{array}{l}\text { biconvex and well-made, edge angle } \\
\text { is } 40^{\circ}\end{array}$ \\
\hline $143-1$ & $27-\mathrm{B}$ & 3 & $52+$ & $42+$ & 14 & & & & $\mathrm{C}$ & proximal of Clear Fork, foreign chert \\
\hline $218-2$ & $28-\mathrm{G}$ & 6 & $48+$ & $35+$ & 14 & & & & $\mathrm{~B}$ & Clear Fork prox \\
\hline $227-2$ & $32-\mathrm{V}$ & 1 & $34+$ & 37 & 12 & & & & $\mathrm{~B}$ & Clear Fork medial \\
\hline $288-9$ & $* *$ & & $57+$ & 40 & 9 & & & & $\mathrm{~B}$ & prox end, edges dulled \\
\hline \multicolumn{11}{|c|}{ ADZES MADE ON POINT FRAGMENTS } \\
\hline $259-2$ & $14-\mathrm{O}$ & surface & 32 & 20 & 7 & & & & & medial fragment \\
\hline $292-1$ & $28-\mathrm{B}$ & 5 & 36 & 25 & 7 & 25 & 21 & & & proximal end of St. Mary’s Hall \\
\hline \multicolumn{11}{|c|}{ MISCELLANEOUS ADZE } \\
\hline $100-1$ & $30-\mathrm{G}$ & 3 & 53.5 & 32 & 8.5 & & & & $\mathrm{X}$ & triangular, unifacial, made on flake \\
\hline $118-2$ & $29-\mathrm{F}$ & 1 & $39+$ & $41+$ & 12 & & & & $\mathrm{~B}$ & adze bit snap fracture \\
\hline $131-1$ & $27-\mathrm{C}$ & 4 & 60 & 29 & 9 & & & & $\mathrm{X}$ & $\begin{array}{l}\text { unifacial retouch, wear on wider end, } \\
\text { oval }\end{array}$ \\
\hline $150-1$ & $25-\mathrm{C}$ & $2 \& 3$ & $59+$ & 26 & 7 & & & & $\mathrm{X}$ & $\begin{array}{l}\text { small triangular biface adze, note } \\
\text { bevel on wide end }\end{array}$ \\
\hline \multicolumn{11}{|c|}{$\begin{array}{l}\text { * Types of breakage patterns were coded as follows: } \mathrm{X} \text { indicates the point is complete; A, direct impact break at the tip, barbs, or base (often appears as a "burin-like" break, } \\
\text { though more commonly as a flute-like flake extending from the tip down one face of the point); B, snap or bending fracture probably caused by impact on used points or } \\
\text { manufacturing mistakes on preforms; C, burned (usually marked by crazing fractures and pot lid fractures on the artifact); D, reworked tip or blade. Points with more than } \\
\text { one of these attributes were labeled accordingly; e.g. if evidence for both direct impact and snap break was observed, the breakage pattern was coded as A/B. }\end{array}$} \\
\hline
\end{tabular}




\section{Appendix D. Other Tools and Artifacts, continued}

\begin{tabular}{|c|c|c|c|c|c|c|c|c|c|c|}
\hline $\begin{array}{c}\text { Spec. } \\
\text { No. }\end{array}$ & Unit & Level & $\begin{array}{c}\text { Length } \\
(\mathrm{mm})\end{array}$ & $\begin{array}{c}\text { Width } \\
(\mathrm{mm})\end{array}$ & $\begin{array}{l}\text { Thick- } \\
\text { ness } \\
(\mathrm{mm})\end{array}$ & $\begin{array}{c}\text { Stem } \\
\text { Length } \\
(\mathrm{mm})\end{array}$ & $\begin{array}{l}\text { Stem } \\
\text { Width } \\
(\mathrm{mm})\end{array}$ & $\begin{array}{c}\text { Bit } \\
\text { Width } \\
(\mathrm{mm})\end{array}$ & $\begin{array}{l}\text { Break } \\
\text { Type* }\end{array}$ & Notes, Comments \\
\hline $202-2$ & $34-\mathrm{U}$ & 3 & 47 & 28 & 7 & & & & $\mathrm{X}$ & biface \\
\hline $235-1$ & $10-\mathrm{N}$ & surface & 52 & 41 & 9.5 & & & & $\mathrm{X}$ & triangular unifacial \\
\hline $283-3$ & $39-W$ & 2 & $45+$ & 38 & 11 & & & & $\mathrm{~B}$ & biface, battered bit and edges \\
\hline $288-32$ & $* *$ & & $42+$ & 33 & 11 & & & & $\mathrm{~B}$ & beveled distal end \\
\hline \multicolumn{11}{|c|}{ LUNATE UNIFACE } \\
\hline $34-1$ & $31-\mathrm{G}$ & 5 & 80 & 33 & 12.5 & & & & $\mathrm{X}$ & $\begin{array}{l}\text { lunate outline, thick, beveled on in- } \\
\text { side edge of concavity }\end{array}$ \\
\hline \multicolumn{11}{|c|}{ OVAL BIFACE } \\
\hline $177-1$ & $22-\mathrm{G}$ & 2 & 55 & 345 & 6.5 & & & & & \\
\hline \multicolumn{11}{|c|}{ BURINATED BIFACE } \\
\hline $277-1$ & $38-\mathrm{V}$ & 3 & 43 & 27 & 8 & & & & $\mathrm{~A} / \mathrm{B}$ & burinated biface fragment \\
\hline $\begin{array}{l}\text { * Types of } \\
\text { though mo } \\
\text { manufactu } \\
\text { one of thes }\end{array}$ & $\begin{array}{l}\text { kage pat } \\
\text { mmonly } \\
\text { mistake }\end{array}$ & $\begin{array}{l}\text { rns were co } \\
\text { s a flute-lik } \\
\text { on preforms }\end{array}$ & ded as follo & $\mathrm{X}$ indica & es the poin & complet & $\begin{array}{l}\text { ind pot } 1 \\
\text { and snap }\end{array}$ & $\begin{array}{l}\text { actures } \\
\text { ak was }\end{array}$ & $\begin{array}{l}\text { ne artifact } \\
\text { cved, the b }\end{array}$ & $\begin{array}{l}\text { bs, or base (often appears as a "burin-like" break } \\
\text { probably caused by impact on used points or } \\
\text {; D, reworked tip or blade. Points with more than } \\
\text { eeakage pattern was coded as A/B. }\end{array}$ \\
\hline
\end{tabular}





\section{References Cited}

Abbott, James T. and William N. Trierweiler (editors)

1995 NRHP Significance Testing of 57 Prehistoric Archeological Sites on Fort Hood, Texas, Vol. 2. Archeological Research Management Series, Research Report, Fort Hood Texas, U.S. Army, Fort Hood.

ACHP (Advisory Council on Historic Preservation)

2009 Section 106 Archaeology Guidance. Electronic document, www.achp.gov/archguide, accessed 5 April, 2012.

Arnn, John Wesley III

2012 Land of the Tejas: Native American Identity and Interaction in Texas, AD 13001700. The University of Texas Press, Austin.

Binford, Lewis R.

1980 Willow Smoke and Dogs' Tails: Hunter-Gatherer Settlement Systems and Archaeological Site Formation. American Antiquity 45:4-10.

2001 Constructing Frames of Reference: An Analytical Method for Archaeological TheoryBuilding Using Hunter-Gatherer and Environmental Data Sets. University of California Press, Berkeley.

Black, Stephen L.

1989 Central Texas Plateau Prairie. In From the Gulf Coast to the Rio Grande: Human Adaptation in the Central, South, and Lower Pecos, Texas, edited by Thomas R. Hester, Stephen L. Black, D. Gentry Steele, Ben W. Olive, Anne A. Fox, Karl J. Reinhard, and Leland C. Bement, pp.17-38. Research Series No. 33. Arkansas Archeological Survey, Fayetteville.

Black, Stephen L., and Al J. McGraw

1985 The Panther Springs Creek Site: Cultural Change and Continuity within the Upper Salado Creek Watershed, South-Central Texas. Archaeological Survey Report 100. Center for Archaeological Research, The University of Texas at San Antonio.

Bolton, Herbert E.

1970 Texas in the Middle Eighteenth Century: Studies in Spanish Colonial History and Administration. Originally published as Volume 3 of The University of California Publications in History [1915]. Texas State Historical Association, The University of Texas Press, Austin.

Bousman, C. Britt, Barry W. Baker, and Anne C. Kerr

2004 Paleoindian Archeology in Texas. In The Prehistory of Texas, edited by Timothy K. Perttula, pp. 15-97. Texas A\&M Press, College Station. 


\section{References Cited}

Bousman, C. Britt., Michael B. Collins, Paul Goldberg, Thomas Stafford, Jan Guy, Barry W. Baker, D. Gentry Steele, Marvin Kay, Anne Kerr, Glen Fredlund, Phil Dering, Vance Holliday, Diane Wilson, Wulf Gose, Susan Dial, Paul Takac, Robin Balinsky, Marilyn Masson and Joseph F. Powell

2002 The Paleoindian-Archaic Transition: New Evidence from Texas. Antiquity 76:980990.

Bousman, C. Britt, and David L. Nickels

2003 Archaeological Testing of the Burleson Homestead at 41HY37, Hays County, Texas. Archaeological Studies Report No. 4. Center for Archaeological Studies, Texas State University-San Marcos.

Campbell, Thomas N.

1948 The Merrell Site: Archaeological Remains Associated with Alluvial Terrace Deposits. Bulletin of the Texas Archeological and Paleontological Society 19:7-35.

Cecil, Leslie G.

2011 Descriptive and Petrographic Report and Summary for Pottery from 41HY163, Zatopec. In Prehistoric Life, Labor, and Residence in Southeast Central Texas: Results of Data Recovery at 41HY163, the Zatopec Site, San Marcos, Texas, edited by Jon C. Lohse, pp. 173-188. Archaeological Studies Report No. 18, Center for Archaeological Studies, Texas State University-San Marcos.

Collins, Michael B.

1994 Chronometric Investigations. In Archaic and Late Prehistoric Human Ecology in the Middle Onion Creek Valley, Hays County, Texas, by Robert A. Ricklis and Michael B. Collins, pp. 499-505. Studies in Archeology 19. Texas Archeological Research Laboratory, The University of Texas at Austin.

1995 Forty Years of Archeology in Central Texas. Bulletin of the Texas Archeological Society 66:361-400.

2004 Archeology in Central Texas. In The Prehistory of Texas, edited by Timothy K. Perttula, pp. 205-265. Texas A\&M University Press, College Station.

Collins, Michael B. (assembler and editor)

1998 Wilson-Leonard, an 11,000-Year Archeological Record of Hunter-Gatherers in Central Texas. Studies in Archeology 31, Texas Archeological Research Laboratory, The University of Texas at Austin and Archeology Studies Program, Report 10, Texas Department of Transportation, Environmental Affairs Division, Austin.

Collins, Michael B., and Kenneth M. Brown

2000 The Gault Gisement: Some Preliminary Observations. Current Archeology in Texas 2(1):163-166. 
Crass, David Colin

2007 The Crisis in Communication: Still With Us? In Archaeology and Cultural Resource Management: Visions for the Future, edited by Lynne Sebastian and William D. Lipe, pp. 253-282. SAR Press, Santa Fe.

Crawford, Daymond D.

1965 The Granite Beach Site, Llano County, Texas. Bulletin of the Texas Archeological Society 36:71-98.

Decker, Susan, Stephen L. Black, and Thomas Gustavson

2000 The Woodrow Heard Site, 41UV88, A Holocene Terrace Site in the Western Balcones Canyonlands of Southwestern Texas. Studies in Archeology 33, Texas Archeological Research Laboratory, The University of Texas at Austin, and Archeology Studies Program, Report 14, Texas Department of Transportation, Austin.

Dial, Susan W.

1998 Chapter 15: Clear Fork Tools. In Wilson Leonard: An 11,000-year Archeological Record of Hunter-Gatherers in Central Texas, Vol. II: Chipped Stone Artifacts, assembled and edited by M. B. Collins, pp. 507-535. Studies in Archeology 31, Texas Archeological Research Laboratory, The University of Texas at Austin, and Archeology Studies Program, Report 10, Texas Department of Transportation Environmental Affairs Division, Austin.

Dial, Susan W., Anne C. Kerr, and Michael B. Collins

1998 Chapter 13: Projectile Points. In Wilson Leonard: An 11,000-year Archeological Record of Hunter-Gatherers in Central Texas, Vol. II: Chipped Stone Artifacts, assembled and edited by M. B. Collins, pp. 313-446. Studies in Archeology 31, Texas Archeological Research Laboratory, The University of Texas at Austin, and Archeology Studies Program, Report 10, Texas Department of Transportation Environmental Affairs Division. Austin.

Dibble, David S., and Dessamae H. Lorrain

1968 Bonfire Shelter: A Stratified Bison Kill Site, Val Verde County, Texas. Miscellaneous Papers No. 1. Texas Memorial Museum Publications, The University of Texas at Austin.

Dillehay, Thomas D.

1974 Late Quaternary Bison Population Changes on the Southern Plains. Plains Anthropologist 19(64):180-196.

Dornheim, Sharon

2002 The Archaeology of Site 41BN63, Bandera County, Texas. Unpublished Master's thesis, Department of Anthropology, The University of Texas at Austin. 


\section{References Cited}

Duffield, Lathel F.

1963 The Wolfshead Site:An Archaic-Neo-American Site in San Augustine County, Texas. Bulletin of the Texas Archeological Society 34:83-141.

Epstein, Jeremiah F.

1969 The San Isidro Site: an Early Man Campsite in Nuevo Leon, Mexico. Anthropology Series 7. Department of Anthropology, The University of Texas at Austin.

Ferring, C. Reid

2001 The Archaeology and Paleoecology of the Aubrey Clovis Site (41DN479), Denton County, Texas. Center for Environmental Archaeology, Department of Geography, University of North Texas, Denton.

Garber, James F., Susan Bergman, Billy Dickinson, Robert W. Hays, III, Jane Simpson, and Jeffrey Stefanoff

1983 Excavations at Aquarena Springs, San Marcos, Texas. La Tierra 10(2):28-38.

Garber, James F., and Michael D. Orloff

1984 Excavations at 41HY37: An Archaic Site on the Balcones Escarpment in San Marcos, Texas. La Tierra 11(2):31-37.

Gerstle, A., Thomas C. Kelly, and Cristi Assad

1978 The Fort Sam Houston Project: An Archaeological and Historic Assessment. Archaeological Survey Report 40. Center for Archaeological Research, The University of Texas at San Antonio.

Goode, Glenn T.

2002 The Anthon Site:A Prehistoric Encampment in Southern Uvalde County, Texas. Report 38, Archeological Studies Program, Texas Department of Transportation, Austin.

Hall, Grant D.

1981 Allens Creek: A Study in the Cultural Prehistory of the Brazos River Valley, Texas. Texas Archaeological Survey Research Report No. 61. The University of Texas at Austin.

Hard, Robert J., and M. Anne Katzenberg

2011 Stable Isotope Study of Hunter-Gatherer-Fisher Diet, Mobility, and Intensification on the Texas Gulf Coastal Plain. American Antiquity 76:709-751.

Haynes, Vance C.

1991 Geoarchaeological and Paleohydrological Evidence for a Clovis Age Drought in North America and Its bearing on Extinction. Quaternary Research. Vol. 31, pp. 438-450. 
Henderson, Jerry

2001 Excavations at the Rainey Site (41BN33), A Late Prehistoric Sinkhole Site in Bandera County, Texas. Environmental Studies Program, Report 5. Texas Department of Transportation, Austin.

Hester, Thomas R.

1971 Archeological Investigations at the La Jita Site, Uvalde County, Texas. Bulletin of the Texas Archeological Society 42:51-148.

1983 Late Paleo-Indian Occupations at Baker Cave, Southwestern Texas. Bulletin of the Texas Archeological Society 53:101-119.

1991 The Plainview Points from the St. Mary's Hall Site, South Central Texas. La Tierra 18(2): $1-4$.

2011 A Summary of the 2011 Texas Archeological Society Field School. Texas Archeology 55(4):1-9.

2012 A typological study of the St. Mary's Hall type: chronology, technological and metric traits, and occurrence at sites in Texas. Unpublished manuscript.

Horrell, Christopher E.

1999 Drawing Linkages Between Global and Local Processes: Archaeological Investigations of Villa San Marcos de Neve, a Spanish Colonial Town on the Frontier. Unpublished Master's thesis, Department of Anthropology, The University of Texas at San Antonio.

Houk, Brett A., Kevin A. Miller, and Eric R. Oksanen

2008 The Gatlin Site (41KR621): Investigating Archaic Lifeways on the southern Edwards Plateau of Central Texas. SWCA Cultural Resources Report 149, Texas Department of Transportation, Archeological Studies Program Report 108, Austin.

Houk, Brett A., Kevin A. Miller, and Eric R. Oksanen

2009 The Gatlin Site and the Early-to-Middle Archaic Chronology of the Southern Edwards Plateau. Bulletin of the Texas Archeological Society 80:51-75.

Hudler, Dale

1997 Determining Clear Fork Tool Fuction Through Use-Wear Analysis:A Discussion of Use-Wear Methods and Clear Fork Tools. Studies in Archeology 25. Texas Archeological Research Laboratory, The University of Texas at Austin.

Jelks, Edward B.

1978 Diablo Range. In Chronologies in New World Archaeology, edited by R. E. Taylor and Clement W. Meighan, pp. 71-111. Academic Press, New York. 


\section{References Cited}

Jenkins, J. H., and K. Kesselus

1990 Edward Burleson: Texas Frontier Leader. Jenkins Publishing Company, Austin.

Jennings, Thomas A.

2008 San Patrice Technology and Mobility across the Plains-Woodlands Border. Memoir 12, Oklahoma Anthropological Society, and R.E. Bell Monographs in Anthropology No. 5. Sam Noble Oklahoma Museum of Natural History, Norman.

Johnson, Amber L., and Robert J. Hard

2008 Exploring Texas Archaeology with a Model of Intensification. Plains Anthropologist 53:137-153.

Johnson, LeRoy, Jr.

1964 The Devil's Mouth Site: A Stratified Campsite an Amistad Reservoir, Val Verde County, Texas. Archeology Series No. 6. Department of Anthropology, The University of Texas at Austin.

1991 Early Archaic Life at the Sleeper Archaeological Site, 41BC5, of the Texas Hill Country, Blanco County, Texas. Publications in Archaeology, Report 39, Highway Design Division, Texas State Department of Highways and Public Transportation, Austin.

1995 Past Culture and Climate at Jonas Terrace, 41ME29, Medina County, Texas. Office of the State Archeologist Report 40, Texas Department of Transportation and Texas Historical Commission, Austin.

2000 Life and Death as Seen at the Bessie Kruze Site (41WM13) on the Blackland Prairie of Williamson County, Texas. Report 22. Texas Department of Transportation, Environmental Affairs Division, Archeology Studies Program, Austin.

Johnson, LeRoy, Jr., and Glenn T. Goode

1994 A New Try at Dating and Characterizing Holocene Climates, as Well as Archeological Periods, on the Eastern Edwards Plateau. Bulletin of the Texas Archeological Society 65:1-51.

Johnson, LeRoy Jr., Dee Ann Suhm, and Curtis D. Tunnell

1962 Salvage Archeology of Canyon Reservoir: The Wunderlich, Footbridge, and Oblate Sites, Texas Memorial Museum Bulletin, No. 5, Austin.

Johnson, Eileen, and Vance T. Holliday

1984 Comments on "Large Springs and Early American Indians" by Joel L. Shiner. Plains Anthropologist 29:65-70. 
Kalter, Ardi J., Robert M. Rogers, and Michael N. Smith

2005 Analysis and Reporting for 41FY135, the Sandbur Site, Fayette County, Texas. Archeological Studies Program 73. Texas Department of Transportation, Austin.

Karbula, James W.

2000 Investigations at the Eckols Site (41TV528): A Stratified Prehistoric Terrace Site on Barton Creek in Travis County, Texas. Unpublished Ph.D. dissertation, Department of Anthropology, The University of Texas at Austin.

Kelly, Thomas C.

1961 The Crumley Site: A Stratified Burnt Rock Midden, Travis County, Texas. Bulletin of the Texas Archeological Society 31:239-272.

Kibler, W. Karl and Ann M. Scott

2000 Archaic Hunters and Gatherers of the Balcones Canyonlands: Data Recovery at the Cibolo Crossing Site (41BX377), Camp Bullis Military Reservation, Bexar County, Texas. Report of Investigations 126, U. S. Army Corps of Engineers, Fort Worth District.

Kibler, Karl W.

2012 The Role of Exotic Materials in Toyah Assemblages in a Late Prehistoric Economic and Social System. In The Toyah Phase of Central Texas: Late Prehistoric Economic and Social Process, edited by Nancy A. Kenmotsu and Douglas K. Boyd, pp. 76-89. Texas A\&M University Press, College Station.

Krieger, Alex D.

1944 The Typological Concept. American Antiquity 9(3):271-288.

LaBudde, Gregory J.

2008 A Functional Analysis of Archaic Foreshafts and Other Wooden Dart Components from the Northern Chihuahuan Desert. Unpublished Master's thesis, Department of Anthropology, Texas State University-San Marcos.

Leezer, Carole A., editor

2013 Prehistoric Life Along the Banks of Spring Lake: Results and Analysis of the Southwest Texas State Field Schools (1996-1998), San Marcos, Hays County, Texas. Archaeological Studies Report No. 31. Center for Archaeological Studies, Texas State University-San Marcos. 


\section{References Cited}

Leezer, Carole A., David M. Yelacic, Jon C. Lohse, and Frederick H. Hanselmann

2011 Results of Cultural Resources Survey for Spring Lake Section 206 Aquatic

Ecosystem Restoration Project, Texas State University-San Marcos, Hays County, Texas. Archaeological Studies Report 22. Center for Archaeological Studies, Texas State University-San Marcos.

Leezer, Carole A., David M. Yelacic, Amy E. Benton, Jacob Hooge, and Patricia Christmas

2012 Results of Archaeological Monitoring of the Spring Lake Section 206 Aquatic Ecosystem Restoration Project, Texas State University-San Marcos, Hays County, Texas. Archaeological Studies Report No. 30. Center for Archaeological Studies, Texas State University-San Marcos.

Lemke, Ashley, and Cinda Timperley

2008 Preliminary Analysis of Turtle Material from the Gault Site, Texas. Current Research in the Pleistocene 25:115-117.

Lohse, Jon C.

1999 Lithics from the San Antonio de Valero Mission: Analysis of Materials from 1979

Excavations at the Alamo. Bulletin of the Texas Archeological Society 70:265-279.

Lohse, Jon C. (editor)

2011 Prehistoric Life, Labor and Residence in southeast Texas. Results of Data Recovery at the Zatopec Site, San Marcos, Texas. Archaeological Studies Report 18. Center for Archaeological Studies, Texas State University, San Marcos.

Lohse, Jon C., Stephen L. Black, and Laly M. Cholak

2014 Toward an Improved Radiocarbon Chronology for Central Texas. Bulletin of the Texas Archeological Society, in press.

Lukowski, P. D.

1988 Archaeological Investigations at 41BX1, Bexar County, Texas. Archaeological Survey Report 135. Center for Archaeological Research, The University of Texas at San Antonio.

Mahoney, Richard B., Harry J. Shafer, Steve A. Tomka, Lee C. Nordt and Raymond P. Mauldin 2003 Royal Coachman (41CM111), An Early Middle Archaic Site Along Cordova Creek in Comal County, Texas. Archaeological Survey Report 232, Center for Archaeological Research, The University of Texas at San Antonio, and Report 49, Archeological Studies Program, Texas Department of Transportation, Austin. 
McKinney, Wilson W., C. Britt Bousman, Dave L. Nickels, and K. A McRae

1998 Chapter 8: Artifact Analysis. In Test Excavations at the Culebra Creek Site, 41BX126, Bexar County, Texas, edited by D. L. Nickels, C. B. Bousman, J. D. Leach, and D. A. Cargill, pp. 146-190. Archaeological Survey Report 265, Center for Archaeological Research, The University of Texas at San Antonio.

Meltzer, David J., Lawrence C. Todd, and Vance T. Holliday

2002 The Folsom (Paleoindian) Type Site: Past Investigations. American Antiquity 67(1):5-36.

Meltzer, David J.

2006 Folsom: New Archaeological Investigations of a Classic Paleoindian Bison Kill. University of California Press, Berkley.

Miller, E. O., and Edward B. Jelks

1952 Archeological Investigations at the Belton Reservoir, Coryell County, Texas. Bulletin of the Texas Archeological Society 23:186-217.

Munoz, Cynthia M., Raymond Mauldin, and Robert J. Hard

2011 Stable Isotope Analysis of Human Skeletal Remains from 41HY163 with Comparative Analysis of Remains from 41HY161. In Prehistoric Life, Labor, and Residence in Southeast Central Texas: Results of Data Recovery at 41HY163, the Zatopec Site, San Marcos, Texas, edited by Jon C. Lohse, pp. 343-350. Archaeological Studies Report No. 18, Center for Archaeological Studies, Texas State University-San Marcos.

Nickels, David L., C. Britt Bousman, Jeff D. Leach and Diane A. Cargill

2001 Test Excavations at the Culebra Creek Site, 41BX126, Bexar County, Texas. Archaeological Survey Report No. 265, Center for Archaeological Research, The University of Texas at San Antonio.

Parsons, Mark L.

19651963 Test Excavations at Fate Bell Shelter, Amistad Reservoir, Val Verde County, Texas. Miscellaneous Paper 4, Texas Archeological Salvage Project, The University of Texas at Austin.

Pfeiffer, Leslie

2001 The Cibolo Creek Site. Central States Archaeological Journal 48(1):56-57.

Prewitt, Elton R.

1966 A Preliminary Report on the Devils Rockshelter Site, Val Verde County, Texas. Texas Journal of Science 18(2):206-224. 


\section{References Cited}

1981 Cultural Chronology in Central Texas. Bulletin of the Texas Archeological Society 52:65-89.

1983 From Circleville to Toyah: Comments on Central Texas Chronology. Bulletin of the Texas Archeological Society 54:201-238.

1995 Distributions of Typed Points in Texas. Bulletin of the Texas Archeological Society $66: 83-173$.

Quigg, J. Michael., Jeffrey D. Owens, Paul M. Matchen, Grant D. Smith, Robert A. Ricklis, Mercedes C. Cody, and Charles D. Frederick

2008 The Varga Site: A Multicomponent, Stratified Campsite in the Canyonlands of Edwards County, Texas, Volumes I and II. Archeological Studies Program Report No. 110, Environmental Affairs Division, Texas Department of Transportation, and Technical Report No. 35319, TRC Environmental Corporation, Austin.

Reynolds, Alexis and Maryellen Russo

2012 Reconnaissance Level Historic Resources Survey Report: State Loop 82 from Thorpe Lane to Charles Austin Street, Hays County, Texas, CSJ: 0016-09-033. Blanton \& Associates, Inc., Austin.

Ricklis, Robert A.

2011 New Perspectives on the Archaic of the Texas Coastal Plain: The Buckeye Knoll Site (41TV98) on the Lower Guadalupe River near Victoria, Texas. Bulletin of the Texas Archeological Society 82:31-76.

Ringstaff, Christopher W.

2000 A Study of Landform Evolution and Archaeological Preservation at Site 41HY165, San Marcos, Texas. Unpublished Master's thesis, Department of Geography, Southwest Texas State University, San Marcos.

Ross, Richard E.

1965 The Archeology of Eagle Cave. Papers of the Texas Archeological Salvage Project 7, The University of Texas at Austin.

San Marcos Horizons City Master Plan

1996 Chapter Two, San Marcos Today. Electronic website: http://www.ci.san-marcos. tx.us/Modules/ShowDocument.aspx?documentid=4227, accessed September 12, 2012 .

Schaetzl, Randall J., and Sharon Anderson

2005 Soils: Genesis and Geomorphology. Cambridge University Press. 
Shafer, Harry J.

1963 Test Excavations at the Youngsport Site: A Stratified Terrace Site in Bell County, Texas. Bulletin of the Texas Archeological Society 24:57-82.

Shiner, Joel L.

1981 History, Economy, and Magic at a Freshwater Spring. In the Realms of Gold, Proceedings of the 10th Conference on Underwater Archaeology. pp 202-203.

1983 Large Springs and Early American Indians. Plains Anthropologist 28:1-7.

1984a A Reply to Johnson and Holliday. Plains Anthropologist 29:71-72.

1984b The Spring Lake Site. Unpublished MS on file, Center for Archaeological Studies, Texas State University-San Marcos.

Schuetz, M. K.

1957 A Report on Williamson County Mound Material. Bulletin of the Texas Archeological Society 28: 135-168.

Smith, Michael E., and Eric R. Oksanen

2008 Data Recovery Methods and Summary of Results. In The Gatlin Site (41KR621): Investigating Archaic Lifeways on the Southern Edwards Plateau of Central Texas, pp. 7-1 to 7-28. SWCA Cultural Resources Report 149, Texas Department of Transportation, Archeological Studies Program Report 108, Austin.

Society for American Archaeology.

ND Editorial Policy, Information for Authors, and Style Guide. Electronic document. http://www.saa.org/Portals/0/SAA/Publications/StyleGuide/styleguide.pdf, accessed September 25, 2012.

Sollberger, J.B.

1967 A New Type of Arrow Point with Speculations as to its Origin. The Record 23(3). Dallas Archeological Society, Dallas, Texas

Sorrow, William M., Harry J. Shafer, and Richard E. Ross

1967 Excavations at Stillhouse Hollow Reservoir. Papers of the Texas Archeological Salvage Project 11, The University of Texas at Austin.

Spielmann, Katherine A. (editor)

1991 Farmers, Hunters, and Colonists: Interaction Between the Southwest and the Southern Plains. University of Arizona Press, Tucson. 


\section{References Cited}

Story, Dee Ann

1985 Adaptive Strategies of Archaic Cultures of the West Gulf Coastal Plain. In Prehistoric Food Production in North America, edited by Richard I. Ford, pp. 19-56. Anthropological Papers No. 75. Museum of Anthropology, University of Michigan, Ann Arbor.

Stovall, Frances M., Dorothy W. Kerbow, Maxine Storm, Louise Simon, Dorothy W. Schwartz and Gene Johnson

1986 Clear Springs and Limestone Ledges, A History of San Marcos and Hays County for the Texas Sesquicentennial. The Hays County Historical Commission. Nortex Press, Division of Eakin Publications, Austin.

Stull, Kyra, and Michelle D. Hamilton

2011 Descriptive Analysis of Skeletal Remains of Three Individuals from Zatopec, with Comparative Analysis of Two Additional Sets of Remains from 41HY161. In Prehistoric Life, Labor, and Residence in Southeast Central Texas: Results of Data Recovery at 41HY163, the Zatopec Site, San Marcos, Texas, edited by Jon C. Lohse, pp. 337-342.Archaeological Studies Report No. 18, Center for Archaeological Studies, Texas State University-San Marcos.

Suhm, Dee Ann, Alex D. Krieger, and Edwards B. Jelks

1954 An Introductory Handbook of Texas Archeology. Bulletin of the Texas Archeological Society 25 .

Takac, Paul R.

1991a Underwater Excavations at Spring Lake, a Paleoindian Site in Hays County, Texas. Current Research in the Pleistocene 8:46-48.

1991b Homebases and the Paleoindian/Archaic Transition in Central Texas. Paper presented at the 1991 Annual Meeting of the Texas Archeological Society.

1992 Seeing the Forest for the Trees?Paleoindian Adaptations in an Ecotone. Paper presented at the 57th Annual Meeting of the Society for American Archaeology.

Taylor, Walter W.

1964 Tethered Nomadism and Water Territoriality: An Hypothesis. Actas y Memorias, 35th Congreso Internacional de Americanistas, Mexico, D. F.

Texas Beyond History

2011a Arenosa Shelter Radiocarbon Assays. Texas Archeological Research Laboratory, University of Texas at Austin. Electronic document, http://www.texasbeyondhistory. net/arenosa/Arenosa-C14-assays.pdf, accessed September 7, 2012. 
2011b Hinds Cave Artifacts. Texas Archeological Research Laboratory, University of Texas at Austin. Electronic document, http://www.texasbeyondhistory.net/ hinds/artifacts.html\#ston, accessed September 7, 2012.

Thoms, Alston V.

2008 Ancient Savannah Roots of the Carbohydrate Revolution in South-Central North America. Plains Anthropologist 53:121-136.

Thoms, Alston V., and Patricia A. Clabaugh

2011 The Archaic Period at the Richard Beene Site: Six Thousand Years of HunterGatherer Family Cookery in South-Central North America. Bulletin of the Texas Archeological Society 82:77-115.

Tomka, Steve A., Harry J. Shafer, and Raymond P. Mauldin

2003 Chapter 12: Lithic Technology at 41MM340. In Data Recovery Excavations at 41MM340:A Late Archaic Site along Little River in Milam County, Texas, by R. B. Mahoney, S. A. Tomka, R. P. Mauldin, H. J. Shafer, L. C. Nordt, R. D. Greaves, and R. R. Galdeano, pp.133-154. Archeological Studies Program, Report No. 54, Texas Department of Transportation, Environmental Affairs Division, Austin. Archaeological Survey Report No. 340. Center for Archaeological Research, The University of Texas at San Antonio.

Trierweiler, W. Nicholas (editor)

1996 Archeological Testing at Fort Hood: 1994-1995, Vol. 2. Archeological Resource Management Series, Research Report 35, Fort Hood, Texas: U. S. Army, Fort Hood.

Trubitt, Mary Beth

2009 Investigating the Middle Archaic at the Jones Mill Site. Arkansas Archeologist 48:71-84.

Turner, Ellen S., and Thomas R. Hester

1985 A Field Guide to Stone Artifacts of Texas Indians. 1st ed. Texas Monthly Press, Austin.

1999 A Field Guide to Stone Artifacts of Texas Indians. 2nd ed. Taylor Trade Publishing, Rowman and Littlefield, Lanham, Maryland.

Turner, Ellen Sue, Thomas R. Hester, and Richard L. McReynolds

2011 Stone Artifacts of Texas Indians. 3rd ed. Taylor Trade Publishing, Rowman and Littlefield, Lanham, Maryland. 


\section{References Cited}

Turpin, Solveig A., and Leland C. Bement

1992 Skyline Shelter and Devils Triangular Dart Points: Evidence of a New Component of the Lower Pecos Archaic Sequence, Lower Pecos, Texas. Plains Anthropologist 37(138):41-47.

Ulrich, Kristy M.

2011 Around the Neighborhood: UTSA's Center for Archaeological Research Investigates the Early Prehistory of Brackenridge Park. Newsletter of the Southern Texas Archeological Association 37(20:2, 3).

Walter, Tamra L.

2007 Espiritu Santo de Zuniga. A Frontier Mission in South Texas. The University of Texas Press, Austin.

Waters, Michael R., and Thomas W. Stafford

2007 Redefining the Age of Clovis: Implications for the Peopling of the Americas. Science: Vol. 315, No. 5815:1122-1126

Weber, Carey D.

2009 The Laguna Point - Projectile Point Variation in the Early Archaic Prehistoric Period of Texas. La Tierra 36(1-2):99-117,

Weber, Doni

2009 Images of Aquarena Springs. Arcadia Publishing, Chicago.

Weir, Frank A.

1976 The Central Texas Archaic. Unpublished Ph.D. dissertation, Anthropology Department, Washington State University, Pullman.

1985 An Early Holocene Burial at the Wilson-Leonard Site in Central Texas. Mammoth Trumpet 2(1):3.

Wesolowsky, Al. B., Thomas R. Hester, and Douglas R. Brown

1976 Archeological Investigations at the Jetta Court Site (41TV151), Travis County, Texas. Bulletin of the Texas Archeological Society 46:25-68.

Word, James H., and Charles L. Douglas

1970 Excavations at Baker Cave, Val Verde County, Texas. Bulletin No. 16. Texas Memorial Museum, Austin.

Wyckoff, Don G.

1994a Introduction to the 1991 Bulletin. Bulletin of the Oklahoma Anthropological Society Vol. XL for 1991:1-8. 
References Cited

1994b The Calf Creek Horizon in the Osage Savannah. Bulletin of the Oklahoma Anthropological Society, Vol. XL for 1991:9-10.

1995 A Summary of the Calf Creek Horizon in Oklahoma. Bulletin of the Oklahoma Anthropological Society Volume XLII for 1993, pp. 179-210. 



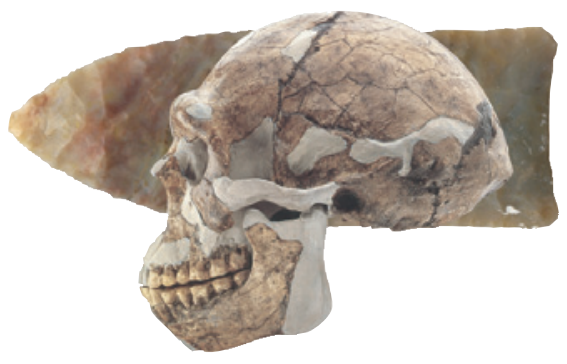

Center for Archaeological Studies

Texas State University-San Marcos

601 University Drive

San Marcos, TX 78666

www.txstate.edu/anthropology/cas/

\section{TEXAS $*$ STATE}

UNIVERSITY

SAN MARCOS

The rising STAR of Texas

A member of The Texas State University System 


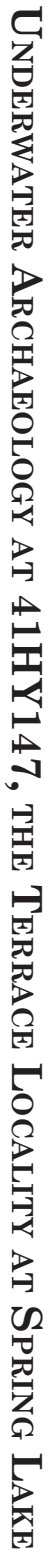

CAS

ASR

28

2013 